\title{
SONORA Y SINALOA EN EL SIGLO XVII
}
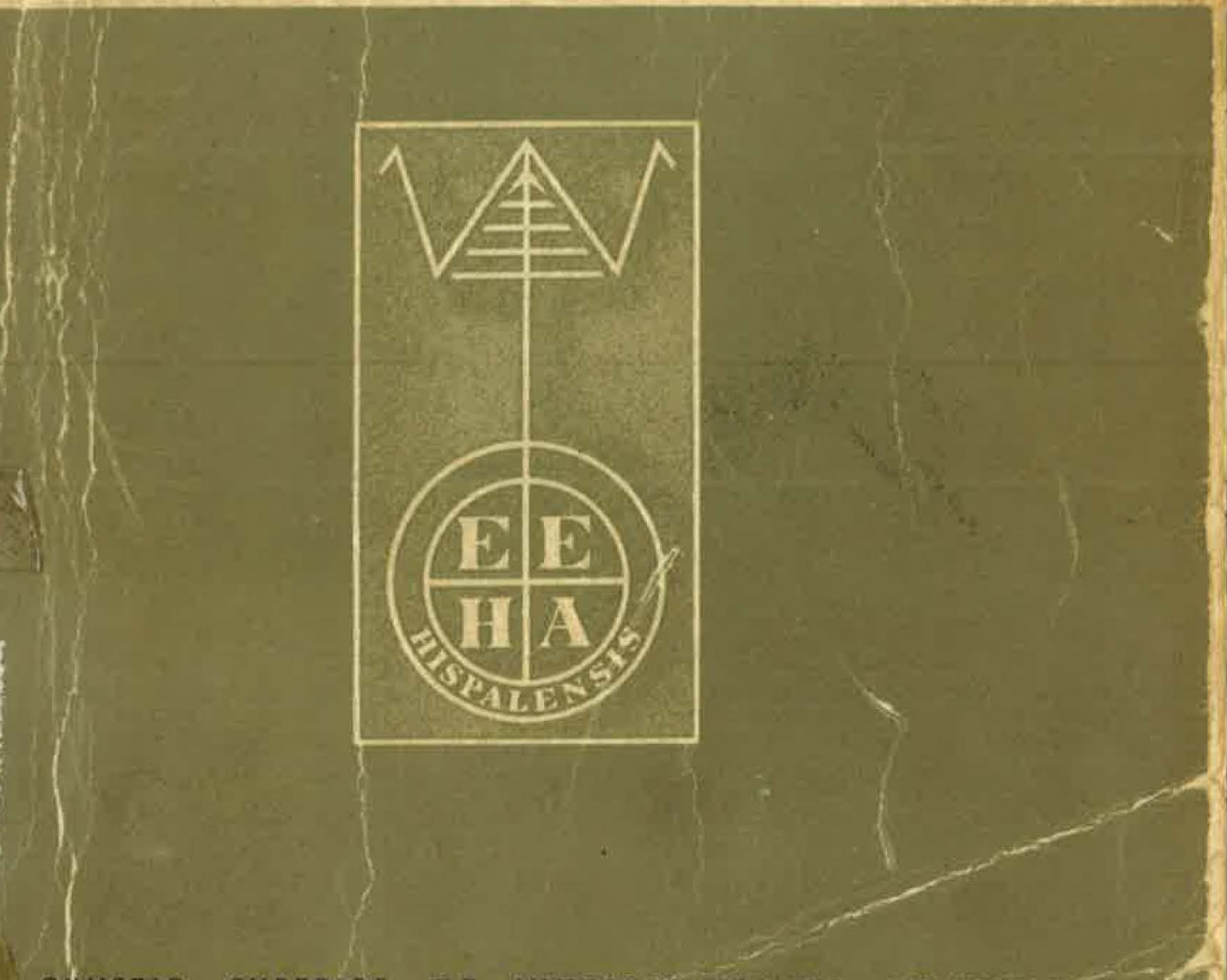

CQUNSEJO SUPERIOR DE INVESTICACIONES CIBNTIEICAS ESCUELA DE ESTUDIOS HISPANO-AMERICANOS DE SEVIIZÁ 


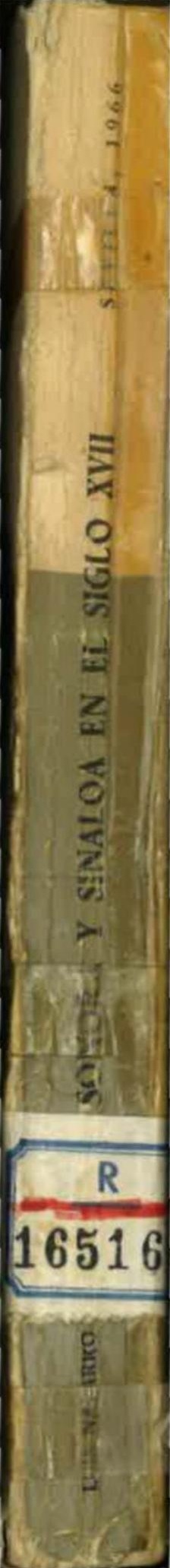




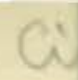


Cindare-2xtadr-sowera

$R / 16516$ $\frac{R}{16516}$ 
SONORA Y SINALOA EN EL SIGLO XVII 
PUBLICACIONES DE LA

ESCUELA DE ESTUDIOS HISPANO-AMERICANOS DE SEVILLA

\section{CLXXVI}

(N. general)

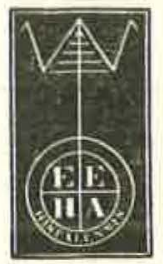

Las noticias, asertos y opiniones contenidos eu este trabajo son de la exclusiva responsahilidad del autor. La Escuela de Estudios Hispano-Americanos sólo responde del interés científico de sus publicaciones. 


\section{LUIS NAVARRO GARCIA}

SONORA Y SINALOA EN EL S IGLO X V II

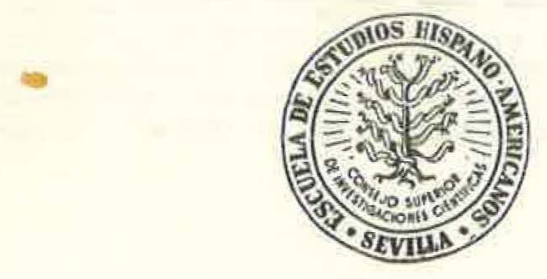

S E V I L L A

1967 
Primera edición

RE SER VADOS LOS DERECHOS

Depósito legal SE - 288 - 1966

G. E. H. A.-Alfonso XII, 12.-SEHLlA. 


\section{INDICE GENERAL}

Págs.

\section{INTRODUCCION}

En torno al título--Propósito del antor.-Sobre las fuentes.

\section{CAPITULO I}

LA TIERRA, EL MAR Y SU APROVECHAMIENTO . . . . . . . I I

Un país pobre e inhóspito.- La vacilante mineria.- La primera riqueza agropecuaria.-La casta y la navegación.-El buceo dé perlas y las pesquerias.-Las salinas.-Un nuevo "norte minero".- - Los caminos de la costa y de la sierra.

\section{C.APITULO HI}

JA POBLACION EN UN SIGLO DE DEPRESION . . . . . . .

Los datos del obispo, en r605.-Los españoles, según Urdiñola, en r604. Los extranjeros de Sinaloa.-La villa de los dos apóstoles.-El hundimiento demográfico de Culiacán.-La multiplicación de la población india por la expansión.-Los grupos indios errantes: tepustla, achires y uparo o seris.--Los españoles en Sonora.--Opatería y Pimería.

\section{CAPITULO III}

LA ADMINISTRACION DE LAS PROVINCIAS . . . . . . . . . 73

Las alcaldías mayores.-Vinculación de las provincias a las autoridades superiores,-Creación y provisión de las alcaldias.-Titulo de alcalde mayor.-Duración del mando y salario.-Juramento y toma de posesión.-Funciones $y$ dependientes del justicia mayor.-Fianzas y residencia,-Tratos y contratos de los alcaldes mayores,-Visitas y visitadores.-Competencias de la audiencia con el gobernador.-Nueva Vizcaya contra el virrey: la disputa por Sinaloa.-Polémica entre audiencia y virrey.-El real de Paredes y el motín de Sinaloa.--Polémica sobre los títulos reales. 
LAS RELACIONES ENTRE GRUPOS . . . . . . . . . . . . I6 I

Las diversas condiciones de los indios y de las provincias.-Encomiendas. esclaritudes y tributos de indios-Mineros, misioneros e indios.-La jaluor de gobierno de los misioncros.-El "Apologético defensorio" de r 657.-Los servicios personales prohibidos,- - La cuestión ante la audiencia.-La actuación del fiscal y la real provisión de 24 de diciembre de r672.- Estalla lá tormenta en Sinaloa.-La andiencia mantiene su postura.-La polémica sobre los indios en Sonora.-La estructura económico-social dé Sonora a la Juz de la controversia.-La comisión de Juan Franco Maldonado.-- Ultimas gestiones de la Compañía y decisión final del Consejo.

\section{CAPITULO $V$}

\section{DOMINACION Y DEFENSA}

Los dos presidios.-La tropa cle Chiansetla.-Presidio y misión en Sinaloa.-Hurdaicle, capitán vitalicio.-Hurdaide en el Mayo y el Yaqui. Por el Yaqui, tierra adentro.-Pedro de Perea, capitán de Sinaloa,-Perea ocupa Nineva Andalucía.-Porter, California y la rebelición tarahumana.-Treinta años de paz.-I68o, el año del desastre. Atondo.-Lázaro Verdugo y la conspiración ópata-apache.-Paz yr rebeldía con Francisco Cuervo de Valdés.-La alarma de I684.-Fernández y Cuervo contra los sumas.-California, la sierra y el pirata.-Quirós y la rebelión de Ostimuli.-Rezábal en el Mayo y en Moris-Seris, pimas y apaches,-Gironza, Mange y Fuensaldaña. 


\section{INTRODUCCION}

\section{EN TORNO AL TÍtULO}

Realmente las palabras que cncabezan este estudio no son en modo alguno la expresión mís correcta de lo que en las siguientes páginas se pretende exponer. Pero son, en todo caso, las menos inadecuadas.

Es verdaderanente inexacto utilizar los términos de "Sonora" y "Sinaloa." para designar la región costera del Pacífico comprendida entre los ríos de las Cañas y Colorado, y entre las cimas de la Sierra Maclre y el océano, si este concepto geográfico ha de insertarse en lá redidad histórica del siglo XVII, como el título pretende a continuación. La razón es obvia: "Sonora y Sinaloa" no eran en aquella centuria sino dos porciones, dos circunscripciones creadas con fines adininistrativos, dentro del ámbito geográfico que grosso modo hemos delimitado líneas arriba, y dentro del cual se incluian otras circunscripciones o provincials que podríamos igualmente entmmerar en el título: Ostimuri, Culiacán, Copala, Chiametla.

E1 110 haber1o hecho así se dehe a que, sobre el deseo de simplificar el membrete de este trabajo, cabían aún dos consideraciones nuás: la primera consiste en que los nombres que se acaban de citar no resultarían expresivos sino para muy contados conocedores de la historia del territorio bajo ellos comprendido; la segunda, en que tan enojosa relación de provincias no sería, históricamente hablando, menos inexacta que la mucho más simplificada que se ha abrazado.

En efecto, basta aludir al hecho que se detallará más adelante: a principios del siglo XVII sólo existían en la costa norocci- 
dental de Nueva España tres provincias : Culiacán, Sinaloa y Chiametla. Las dos primeras pervivieron a lo largo de toda la centuria, pero la tercera se desdobló para dar nacimiento a Copala como entidad administrativa, mientras al norte de Sinaloa, por un fenómeno de expansión, surgían sucesivamente Sonora y Ostimuri, la última de las cuales vive poco más de treinta años del siglo en cuestión.

En fin de cutentas, los términos "Sonora" y "Sinaloa" se han tomado en el título desnudos de todo contenido histórico, y con ellos sólo se alude al espacio geográfico que hoy ocupan los estados que tales nombres ostentan en la República de México, espacio que es precisamente el escenario de los acontecimientos que se va a narrar. Téngase en cuenta que este territorio sólo fue unificado administrativa y políticamente a partir de I733, y aún entonces conservó la doble denominación aquí recogida. Cuando el ministro Gálvez simplificó el nombre de la provincia, fue para darle el de Intendencia de Arizpe, así llamada por el de su capital, pero que tan poco expresivo resulta hoy, por lo que fue asímismo desechado, aparte que sólo tuvo vigencia de I787 a I82I. Aproximadamente 10 mismo podríamos decir del Estado de Occidente, que durante unos años conservó el marco de la Intendencia, para dar finalmente paso a la división que hoy perdura.

Hasta aquí la justificación de la denominación geográfica inserta en la portada. No intentaremos la de la delimitación en el tiempo que allí se indica, que obedece tan sólo al deseo de ahondar en el contenido histórico de la centuria media del período hispánico, y no responde de ninguna manera a un ciclo de acontecir mientos o a un momento histórico determinado, cosa por otra parte tan difícil siendo tantos los sujetos de la narración como el número de las provincias que en ella entran, y sometidas éstas a factores de muy diversa índole.

Los topes inicial, en I600, y final, en I700, serán generalmente respetados en la exposición, aún a costa del riesgo indudable de lesionar la más exacta visión histórica. Pero el historiador 
se ha impuesto voluntariamente esas convencionales barreras para poder concentrar su atención en el objeto primario de la investigación: sacar a la luz los hechos tanto tiempo ignorados, y que en su día podrán ser comprendidos en la nás amplia panorámica de la vida del noroeste de México. Ia realidad que desde el primer momento se le hizo presente a través de los testimonios era sobradamente compleja para permitirle una ampliación en el tiempo que sin duda sería necesaria para alcanzar las fechas que de modo más inmediato se ofrecen como posibles hitos, por superficiales que sean: 1530, la fundación de la villa de San Miguel de Culiaćn, primer establecimiento español en aquellas tierras; I733, unificación del país en la gobernación de Sonora y Sinaloa.

Claramente se advierte que los setenta años anmentados al principio y los treinta acumulados al final totalizarían justamente un siglo más que investigar y elaborar, lo que excedería de las posibilidades presentes del historiador y - ¿nos atrevemos a decirlo?probablemente el resultado no justificaría el esfuer\%o puesto en li. tarea, porque el siglo XVII de Sinaloa y Culiaćn es bastante parco en datos a nuestro alcance, y sería penosísino hallar algunos más. Mientras que el primer tercio del XVIII -cuyo anćlisis tal vez acometamos algún dia - no debe guardar nuchas pinceladas que añadir al cuadro que traza con suficiente nitidez la centuria anterior.

Por último, la ambiciosa vaguedad del título, que parece abarcar la totalidad del acontecer histórico dentro de los nárgenes cronológicos y espaciales ya indicados, oculta a su vez una salvedad: deliberadamente se ha excluido en lo posible, por conocida, la historia de las misiones.

\section{Propósito DEL AUTOR}

No rehuimos en absoluto la espontánea confesión de la arbitrariedad con que se han establecido las fechas topes de la inrestigación. La razón básica de esta decisión ha sido apuntada ya, 
y entra de lleno en nuestro propósito. Deseábamos a todo trance profundizar en el conocimiento de un trozo cualquiera de la historia de las Indias en el siglo XVII, llevados del simple interés de empezar a surcar el mar apenas navegado de esta "centuria de depresión" de la potencia hispánica en todos los órdenes y en todo el globo.

Lo único que condicionó la elección del tema fue nuestro previo contacto con la historia del norte de Nueva España en los siglos XVIII y XIX, de cuyo estudio nos habia quedado la lógica curiosidad de sondear las etapas anteriores de la vida de aquellos países y el anhelo no disimulado de contribuir a salvar el enorme vacío de los actuales conocimientos sobre su historia desde su fundación hasta aproximadamente $175^{\circ}$, vacio del que apenas emergen las confusas alusiones a los sucesivos movimientos de rebeldía de los indios sometidos, y algunas a la casi constantes hostilidades de los bárbaros de la periferia.

Sobre estos presupuestos, nuestro interés se contrajo a los términos ya indicados porque en Sonora y Sinaloa la actividad de los españoles estuvo mucho menos divertida por los acontecimientos del exterior que en cualquier otra de las que vendrian más? tarde a llamarse "provincias internas", y también porque su historia era aún menos conocida que la de Nueva Vizcaya, Nuevo México, o Coahuila.

En efecto, causa asombro advertir que hasta hoy muy poco se ha escrito sobre el tema propuesto por nosotros, y la ignorancia general sobre el pasado de Sonora y Sinaloa es tal que en las historias de estos Estados, en las obras de Mena Castillo, Buelna $y$ otros se pasa habitualmente, con naturalidad incluso y sin el menor recelo, de la fundación de las villas de Culiacán y Sinaloa a la expulsión de los jestuitas, del virrey Montesclaros a su lejano sucesor el marqués de Croix, de Nuño Beltrán de Guzmán y Francisco de Ibarra al visitador José de Gálvez, en suma: de I 530 ó I564 a 1767 . Bache demasiado extenso y profundo para no suscitar la curiosidad del lector. 
Cuando se halla! alguma referencia entre estos polos que ordinarianente se hallan ligados sin transición de ningún estilo, ya se sabe que es para aludir de una 11 otra forma a algúm acontecimianto de la vida misional: quién alude a los progresos de la evangelización, y quién tal vez a una visita del obispo de Guadala jara o de Durango: wno recordará la muerte del P. Tapia, otro la del P. Saeta, otro la figrra del P. Kino. Pero la historia de las misiones es monótona y cansada, siquiera sea porque sus mimeros cultivadores en la Compañía de Jesús conservaron el estilo ingenun de los cronistas oficiales, y nos hablan simultáneamente de sucesos de toda especie interesantes a la extensa familia jesuítica, y de acontecimientos relativos a muy distintos grupos indigenas, sin of recer apenas tna posibilidad de sistematización y coordinación: estilo, por otra parte, que parece de familia e impuesto por el tema, porgue 10 ha sido renovado por sus continuadores, transmitiéndose casi sin variaciones de Pérez de Ribas y Alegre a Cuevas, Decorme y Dumne, como que los últimos beben casi exaclusivmente sus conocimientos en la obra de los primeros.

Con los pies firmemente asentados en la realidad y la elevada capacidad intelectual de sus niembros que la caracteriza, la Compañia se cuidó bien de ir dejando constancia documental de la labor de sus soldados en el norte de Nueva España, y sus historias han saliclo rna y otra ve'z en las prensas americanas y europeas. Si damos la vuelta a la medalla y recordanos la ausencia de cualquier historja de otro tipo que trate de los mismos ciento setenta años en que los jesuitas se movieron en Sonora y Sinaloa, se comprenderá por qué, en el mejor de los casos, se considera a estas regiones' durante el período hispánico casi conno puras "tierras de misiones".

Por eso es tan de agradecer el ramillete de Estudios Históricos de Sinaloa con que el Congreso Mexicano de Historia vino a romper el secular silencio que envolvía tantos aspectos de la vicla de los valles y costas del noroeste de México, en particulari e1) lo referente a los siglos XVI al XIX, con trabajos tan apreciables como los de Amaya Topete, Márquez, Heredia, Nalayama, 
Olea, Quintero y, sobre todo, Herrera Carrillo. Breves apuntes, todos ellos, de pocas páginas y no siempre libres de algunas inexactitudes, hijas por lo común de la poca familiaridad con el pasado de esta región.

Pero seríamos injustos, y pondríamos además la presente obra en riesgo de no ser debidamente valorada si no advirtiésemos a continuación que tal vez el más grave obstáculo que hasta hoy ha subsistido para la elaboración de una historia completa de Sonora y Sinaloa en la época de las alcaldías, la gobernación y la intenđencia ha sido la pérdida casi completa de los archivos locales, la del importantísimo de la audiencia de Nueva Galicia, y los daños sufridos por el de la antigua Nueva Vizcaya, juntamente con la casi nula explotación que de la parte restante de todos ellos se ha hecho hasta ahora.

Con todo lo hasta aquí dicho quede claro que nuestro propósito ha sido desvelar la historia de Sonora y Sinaloa, de r60o a I700, en todo lo referente a su organización administrativa, su gobierno y defensa, su expansión y población, su vida económica y sus problemas sociales. $Y$ en conjunto todo ello no será sino unas páginas de la historia interna del virreinato de Nueva España baịo los Atrstrias.

\section{SOBRE LAS FUENTES}

El material documental para el estudio de la historia civil de Sonora y Sinaloa en la época virreinal a que nos venimos rifiriendo habría que hallarlo en los depósitos de las villas y pueblos de la provincia, en primera instancia. Subsidiariamente recurriríamos a Durango - o Parral-, de cuyo gobernador dependian todas aquellas pequeñas provincias costeras, excepto Culiacán; y por lo tocante a ésta, que formaba parte de la gobernación de Nueva Galicia, habriamos de dirigirnos a Guadalajara. Como en esta última ciudad residía la audiencia territorial con jurisdicción judicial sobre todo el noroeste de México, aquí podríamos también hallar aquella documentación correspondiente a las causas civiles 
o criminales venidas a este tribunal de los territorios por nosotros estudiados. Cina búsqueda más exigente nos llevaría, por viltimo, a México, donde el virrey trataba de vez en cuando asuntos relacionados con la vida de Sonora y Sinaloa, bien por tratarse de materias militares, o de descubrimientos, o hacienda, o bien, porque en un determinado momento se recurría a su suprema autoridad para solventar un punto concreto. Con mayor extensión tratatemos, páginas adelante, del intrincado problema de las jurisdicciones; to que ahora interesa recordar es que sólo Fermando Ocaranza ha dado a conocer algunas piezas de las existentes en el Archivo General de la Nación, presentándolas con s11 estilo peculiar en sus obras sobre el norte de México, y tales piezas no nos propotcionan ayuda apreciahle para nuestro trabajo.

Finalmente, queda un último lugar al que recurrir en demanda de información histórica sobre cualquier punto del viejo Imnerio Español ultramarino. Este lugar no es otro qute el Archivo General de Indias de Sevilla, ane engloha los archivos de los extinguidos Real y Supremo Consejo de las Indias y ministerios de Indias y de Ultramar, haio st1s diversas refundiciones. Sobre este Archivo General de Indias hemos basado esta obra. I a renglón seguido hemos de hacer algmas consideraciones sobre lo glue esto implica.

Sonora y Sinaloa -vale decir, Culiacán, Sinaloa, Chiametla, Copala, Sonora y Ostimuri - eran un rincón olvidado y casi despoblado de ese Imperio, con carácter "provinciano" respecto de provincias de rango secundario como Nueva Galicia y Nueva Vizcaya. ¿Qué asuntos con ellas relacionados podían 1legar a conocimiento de los supremos organismos de la administración central de las Indias? ¿Qué problemas podían en ellas suscitarse de tal importancia que rebasasen la competencia de las autoridades escalonadas que resunidamente hemos citado un par de párrafos más arriba? A bulto podríamos asegurar que ninguno, y la seguridad con que emitiésemos este aserto no se vería turbada, sino todo lo contrario, cuanclo descubriésemos que sólo en un legajo 
de los 37.000... catalogados del Archivo de Indias figuran los nombres de Sonora y Sinaloa. Este legajo es el número 232 de la Sección de Patronato, y precisamente por él iniciamos la penetración al objeto de nuestras investigaciones. Su contenido - trata del servicio personal de los indios en aquellas provincias- su volumen y la importancia de algunas de las personas que en el expediente figuran explica la presencia de este legajo en tal lugar y su remisión al Consejo de Indias.

Sus quinientos sesenta y un folios requirieron varias semanas de paciente estudio. Después, precisados a sondear otros posibles filones de documentación, nos vimos atraídos por tres secciones distintas del Archivo: la que más de inmediato se ofrece es la V, de Audiencias, y dentro de ellas la de Guadalajara. Aquí no cabía otra alternativa que la de repasar los libros registros de reales cédulas, la correspondencia de la audiencia, la de los gobernadores de Nueva Vizcaya, la de los cabildos... unas tres docenas de legajos han sido así buceados para extraer la vaga referencia contenida en una carta, la disposición real qute tal vez afectaba a las provincias objeto de nuestro estudio, algún pliego o algunos autos que por maravilla trataban de sucesos acaecidos en ellas. Raro era el legajo que no nos entregaba algún secreto, pero mucho más raro el que nos proporcionaba alguna información realmente valiosa. Por suerte, todo ello venía perfectamente a completar, a rellenar huecos en el material aprovechado en las otras Secciones abordadas.

Esta otra Sección es la VI que recoge los papeles de Escribanía de Cámara: en sus cuantiosos fondos tan escasamente consultados se hallan los juicios de residencia y los pleitos resueltos en el Consejo de Indias, y en ellos se da la otra excepción importante a aquel juicio que inicialmente debía retraernos de emprender ntna investigación sobre Sonora y Sinaloa en el siglo XVII en el archivo sevillano. En efecto, entre las residencias de los funcionarios indianos de toda clase se hallan las de un alcalde de Sonora y dos de Sinaloa - Cuaervo, Terán y Rezábal- con abun- 
dantisima documentación original sobre estas provincias. $Y$ en los abultados autos de juicios de residencia de los gobernadores de Nueva Vizcaya es frectente que aparezcan, por mil motivos, otras referencias a las alcaldias costeras. Así, los quince legajos consultados de esta Sección - número que en la práctica hay al menos que duplicar, porque casi todos estos infolios constan de partes A, B y C-vinieron a suministrar los datos que vertebran nuestro estudio.

Como remate, los atos sobre las guerras con los tarahumaras sublevados, entre los doctnnentos de la Sección de Patronato arrojaron alguna luz sobre la actividad de los capitanes de Sinaloa en estos críticos momentos para boda la obra de los españoles en el noroeste de México.

Sohre esta base hemos trazado nuestra perspectiva de la historia sonorense y sinaloense en la etapa que bien podríamos 1lamar fundacional, en los años en que se echan los cimientos de lo que, tempo adelante, será una provincia en claras vías de desamollo, base económica y demográfica de la expansión española hacia las dos Californias y 1 mo de los bastiones fundamentales para la protección del virreinato contra las oleadas de las tribus nómadas que descendian de las Rocosas.

La tarea no ha sido fácil, pero los frutos compensan, sin duda. los esfuerzos realizados. 


\section{Capitulo I}

\section{LA TIERRA, EL MAR Y SU APROVECHAMIENTO}

\section{UN PAÍS POBRE E INHÓOSPTTO}

Durante el primer tercio del siglo XVIJ, los exigtros establecimientos españoles en el Pacífico noroeste no excedian mucho en extensión a la de! actual Estado de Sinaloa: desde Acaponeta, último pueblo de Nueva Galicia al sur del río de las Cañas, se entraba en el escenario de nuestra historia siguiendo la ruta abierta por Nuño de Guzmán, que se prolongaba más allá de Culiacán - verdadero testimonio viviente de la llegada del conquistador hasta aquellas latiudes - hasta la villa de San Felipe y Santiago de Sinaloa.

Por aquellos dias, Sinaloa, Culiacán y San Sebastián, las tres villas fundadas por Guzmán e Tbarra, eran las únicas poblaciones que ofrecían algunas escasas garantías de perdurabilidad. En ellas, y en un reducido número de efímeros reales de minas, se concentraba la minoría blanca o mestiza que aseguraba al rey de España la soberanía sobre aquellos territorios. Y esta minoría no mostraba síntomas de futuro acrecentamiento, antes al contrario, temíase con frecuencia que tales indivicluos abandonasen sus casas y se retirasen a lugares de más cómoda habitación.

Pero, ¿qué había en Chiametla, Culiacán o Sinaloa que pudiese atraer a nuevos pobladores? La expedición de Nuño Beltrán a lo largo de la costa había fracasado como empresa colonizadora: Culiacán fue salvado por la posterior llegada, a través de la sierra, de Francisco de Ibarra, cuyos dos movimientos inmediatos proporcionaron a la villa de San Miguel el mediocre flanqueo de los 
dos nuevos establecimientos: San Juan de Carapoa - primera expresión de la futura Sinaloa-y San Sebastián. Culiacán obtuvo, pues, recompensa a la generosidad con aue don Pedro de Tovar recibiera al vasco ilustre, pero en lo sucesivo, durante décadas, las fundaciones de Ibarra habrán de atravesar las más azarosas circunstancias. El conquistador se esforzaba contínuamente nor retener a sus hombres y procurar la llegada de algunos nuevus pequeños contingentes. Su obra aquí, como la de Guzmán, estuvo al borde del fracaso; lo casi prodigioso fue que subsistiera.

Entre 10522 y los 26 grados de latitud Norte, en efecto, Sinaloa no presenta un clima mucho mejor que el de la gemela costa del Golfo de México, entre Tampico y la desembocadura del río Grande del Norte. Quien recuerde que esta orilla tamaulipeca del Golfo no fue ocupada por Escandón sino dos siglos después de las correrías de Beltrán e Ibarra, no dejará de extrañarse. La Sierra Madre, y sin duda también un poco la población prehispánica, pueden dar hasta cierto punto razón de la diferencia entre las fechas de colonización. La sierra significaba muchos tesoros ocultos en sus entrañas, que pronto fueron accesibles a los moradores de Chiametla. Los indios, al menos los de la estrecha faja costera, presentaban formas sedentarias de vida, siendo más fácilmente asimilables por ellos al patrón de la civilización española que los del Nuevo Santander.

Pero con todo, la vida era dura e ingrata en la "tierra caliente”, calificativo éste que encierra toda la repulsión que los españoles debían lógicamente sentir por aquellas regiones de clima excesivamente cálido, de ambiente insalubre, donde no podía darse el trigo, y en las que hasta fecha tardía no empezó a introducirse y a prosperar el ganado caballar y vacuno.

La pobreza del país y sus habitantes era casi proverbial. "Padecen mucha necesidad de vestidos y vino - se había escrito de los cuatro primeros misioneros jesuítas de Sinaloa-, porque en aquella provincia, si no es maíz y calabazas y pescado, no tienen otra cosa cosa para el sustento humano, ni hay de donde lo haber, 
porque la provincia es polje, y los pocos vecinos que en ella están, Tilás, y no los puecien socorrer con cosa ninguna". x

Realnente, la tiera encerraba magnificas posibilidades, pero Ios pocos españoles carecian de recursos y de seguridad para poder aprovecharlass. I.os vecinos de Sinaloa declararon todos en este sentido ante Urdiñola. Y ha de advertirse que Sinaloa era, gracias a su latiud, la provincia que más favorable clima ofrecía a la población de origen europeo y sus culcivos. En r6o3, junto a los frutos de ja tierra -gramochiles, ciruelas, higos, zapotes y mezquites, de que los indios obtenían una especie de pan $\mathrm{y}$ vino-, Se citan ya los frutales de Castilla: uvas, higos, granadas, naranjas, limas, limones, plátanos, melones, sandias, cañadulce y otras legumbres.

Culiacán presentaba otro cuadro bien distinto. "De Castilla no se da ningma fruta", dice Mota. En vez del buen temple que elogian tos habitantes de la villa fronteriza, donde no hacía calor ni frio en demasia, en la villa de San Mignel se padecían fuertes calores. El ardiente sol daba un especial color moreno a sus veciros, que Mota y Escobar califica de muy saludable, "pero a los forasteros les hacía cambiar toda la piel en el primer año". z

Culiacán habia tenido fana por los cabalos que allí se criaban, y en su costa, en el vecino puerto de Guayabal, hubo en otro tiempo ganado vacuno en abundancia: pero una y otra fuentes de riqueza habían descaecido hacia I600, hasta el punto de que janás se comía allí canne, si no era trayéndola a muy subidos precios desde la otra vertiente de Sierra Madre. El prolongado aislamiento había dado a Culiacán la peculiarísina fisonomía resultante de haberse acomodado sus pobladores al máximo a las condiciones del país, de suerte que sólo se alimentaban de pescado

I Rodriso del Río de la Loza a S. M., Durango, 8 novienbre 1502. A. G. I., Guadalajara, 2S. (En todas las notas siguientes de este trabajo omititemos la mención cle1 Arehivo General de Indjas, A. G. I., que se sobrentenderá siempre salvo indicación en contratio).

- Mota y Escobar, Don Alonso de la: Descripción geografica de los reinos de Nuead Galicio, Nueća Viscaya y Nueio León. Introducción por Joaquín Iramírez Cabañas. Segunda edición. México, 1940, págs. 98-104. 
y tortillas de maíz - porque el trigo no se da en muchas leguas alrededor, por el temple tan cálido-, y al mismo tiempo se habían mantenido sin evolucionar en lo tocante a su indumentaria española, lo que permitía al obispo de Guadalajara escribir que andaban vestidos a la usanza de los tiempos de Nuño de Guzmán. Por lo demás, vivían tan aislados que jamás se ocupaban de saber si había paz o guerra, si llegaba o salía la flota, ni nadie usaba papel, sino sólo el escribano.

La villa, totalmente construida de adobes, con sus casas de una sola planta, sus calles anchas y rectilíneas y su gran plaza presidida por la iglesia parroquial, acusaba tanto en la ruina de sus edificios, cono en la de sus pobladores, el poco floreciente estado de su economía.

Más al sur, en la extensa zona que llamamos genéricamente Chiametla, país que en los primeros años del XVII se organizaba sobre el patrón de tres alcaldías mayores - Maloya, Copala y San Sebastián-, las condiciones empeoraban de manera notable al hacerse la transición al clima tropical lluvioso, a las poblaciones indígenas de menor densidad de la costa y a la abierta hostilidad de los habitantes de la sierra. También era aquí, lógicamente, donde menos españoles se hallaban. Para Arregui, en los escasos pueblos que se sucedian en las cuarenta y seis leguas de extensión norte-sur de Chiametla, "hay aún menos gente de la que prometen los nombres". 3

Por lo mismo, no parecía esta zona llamada a lograr nunca un desarrollo considerable, no obstante que aquí era donde por primera vez se había topado con yacimientos argentíferos de cierta importancia, y era fama que en los años inmediatos a la fundación de San Sebastián habían dado mucha plata los reales de su contorno. Mota y Escobar busca una curiosa explicación al hecho de que los españoles se resistan a abandonar Chiametla: "aunque son las minas tan pobres, no se les persuade a que se vayan a poblado

3 Arregui, Domingo Lázaro de: Descripción de la Nueva Gulicia. Edición y estudio po: François Chevalier. Sevilla, 1946, pág. Io3. 
que en haciéndose los hombres a vivir en soledad y libertad parece que se olvidan de Dios y de las gentes". 4

\section{LA VACJLANTE MINERÍA}

El esplendor inicial de Chiametla habia sido tan breve que en I59 ya estaba ntevamente en riesgo de despoblarse aquella tierra asperísima y fragosa, caliente y malsana, según la calificó Rodrigo del Río, a la que habia que conducir desde Durango los bastimentos que no producía el suelo. En la sierra había cierta. mente noticia de muchas minas, con cinco descubrimientos poblados, de los que los cuatro antiguos --los de Pinuco, Mataro, Copala y San Bartolomé, situados en distancia de dos a tres leguas unos de otros- eran los que en otro tiempo dieron mucha plata por azogue y fundición, y justificaban la existencia de una Caja Real en lá villa de San Sebastián. En el día no era así por razón de las hostilidades, y los españoles, negros e indios amigos, se mantenian en los reales con mucho peligro. El quinto descubrimiento, las minas de Cacalotán y Maloya, contaba al menos con gente más pacifica en su comarca. 5

De los primitivos reales, en 1604 sólo quedaba el de Panuco, con tres ingenios, dos de ellos de agua y de siete mazos, y el tercero de caballos, con ocho. Este y uno de aquélios habían pertenecido a Hernando te Trejo y a Francisco de Ibara, respectivamente. En el real de Maloya, por las mismas fechas, no había más que dos haciendas de sacar plata, con molinos de agua de ocho mazos, y otras dos de mulas, de ocho y once mazos, se hailaban en el vecino real de San Marcial. En total, siete ingenios pertenecientes a seis dueños, esto era todo cuanto podía encontrarse de riqueza en la extensa Chiametla. 6 Para mayor justificación,

4 Mota, $9 \mathrm{I}$.

5 Rodrigo del Río de la loza a S. M. Vizcaya, 23 octuire, 1591, Guadala. jard, 28 .

6 Mandamientos de Urdiñola, Topia, io enero i604, a los alcaldes mayores de Copala y Maloya, y respuestas de éstos, en expediente de "El cápitán Francisco de Urdiñola sobre que se le haga merced", pieza $1.2,127$ fols. Guadalajara, 28. 
en fecha inmediata a la de las noticias pedidas por Urdiñola, el obispo Mota da noticia 7 de las haciendas de minas de beneficio de azogue, con moliendas de agua, en el real de Panuco, y asienta que el de Mataro, dos leguas adelante, se halla despoblado, aunque todavía se sacan algunos minerales que se llevan a beneficiar al de Panuco. De Maloya y Copala, Mota sólo da el nombre. No es mucho más explícita la audiencia de Guadalajara, que en 1605 recoge como cosa del pasado el recuerdo de la prosperidad de Copala y Mataro y anuncia en cambio como descubrimiento reciente el de las minas de Mayola. ${ }^{8}$

Pero peor era la situación en las restantes poblaciones del litoral; por eso se comprende la excitación que un accidental descubrimiento había de producir en los pobladores, y las disputas que se originarían sobre la jurisdicción a que aquel yacimiento correspondiese. Por octubre de 1603 , gentes de Culiacán habían poblado un real en Vacapa, paraje que los habitantes de Sinaloa reputaban por de esta provincia, a veinte leguas de su capital, así lo declaran a Urdiñola. 9 Este mismo gobernador, cuatro años más tarde, reclama al rey los derechos de Nueva Vizcaya sobre los yacimientos encontrados por un indio de la sierra de Sinaloa en esta alcaldía, en lugares más de cuarenta leguas dentro de los términos de su gobernación, pese a lo cual, tạn pronto se tuvo noticia en la villa de San Miguel, pasó un teniente de alcalde mayor de Culiacún a tomar posesión de los dos primeros descubrimientos, llamados Santiago Carantapa y San Juan, en nombre de Nueva Galicia.

Fue inútil que el gobernador recurriera a la audiencia, porque ésta, como parte interesada, se apresuró a nombrar alcalde mayor de aquellas minas, por lo cual Urdiñola solicitaba de Fe-

7 Mota, go.

8 La audiencia a S. M., Guadalajara, 28 abril I605. Guadalajara, 7.

9 "Información hecha por el gobernador Urdiñola cerca del estado de la provincia de Sinaloa", 4 diciembre 1603. Respuesta a la pregunta 7. En expediente citado en nota 6 , fols. $43-77$, Guadalajara, 28. 
lipe In que sometiese la causa al virrey, to cuya determinación, sin embargo, no nos es conocicla, y si sólo, el propúsito de la audiencia de resistirse a la cesion de las minas, ${ }^{\overline{1}}$ pero la controversia, que no es sino tha de tantas como se produjeron entre las autoridades de Guadalajara y Durango, debió saldarse a favor del último, por clianto en 1633 nos hallamos ante un procurador de esta ciudad que se titula teniente de gobernador y capitán general de la provincia de Carantapa y San Ignacio; ${ }^{2}$ con esta solución quedaron estas minas al nargen de las jurisdicciones costeras que estudianos, siendo así que en I621, de creer el testimonio de Arregui, ya estaban abandonados estos descubrimientos, de restitas del levantaminto de los tepehuanes, después de haber tenido próspera vida de 1608 a 16 I $\%$, contando con tres haciendas de agua y muy ricos metales en su primitivo emplazamiento hasta róio, fecha en qué el real se trasladó al paraje de San Ignacio, doncle hubo ingenio de agua, I3

Las minas de Copala, en fin, freron destruidas con ocasión del mismo levantamiento de los tepehtanes de 1616. "Los indios de aquella provincia escribe Juan López de Vicuna-- dieron una noche sobre las haciendas, $y$ las quenaron y mataron los negros de ellas y algunos espatioles". Desaparecidos los reales, ef hierro que el alcalde mayor tenía para marcar las platas fue a parar a Culiacán, indebidanente. "Esta dicha marea no sirve alli más que para la plata que viene descaminada de los reales de Topia y San Andrés, que los mineros por no pagar el consumido de agogue de S. M. a los que administran el azogue y son alcaldes mayores de aquellos reales y no pagarles lo que les deben de algunas cosas que les dan, los dichos mineros dan la plata a los mercaderes y a otros que entran con bastimentos de la provincia de Culiacán, con

Io Urdiñola a S. M., Parras, 6 abril $160 \%$. Guadalijara, 28, Reales cédulas de t4 abril t609 al virrey Velasco y a la andiencia die Guarlalajara, $236, Z$, 2, fol. 1,260127 .

is La audiencia a S. M., Guadalajara, If cctubre íon. Guadalajara, 8.

I 2 El capitán Diego de Agtiilat Malconatón a S. M., Madrid, 3 I mayo r 623. Guaclalajara, 30 .

I3 Arregui, 106-107. 
una cédula jurada de que es suya, del minero, y que la sacó en su hacienda, y acaso es del rescate, y pierde S. M. dos pares de derechos y el consumido del azogue: el uno de plata de rescate y el otro de plata de diezmo, y la deuda del azogue siempre se está en pie. Y allí en Culiacán, la persona que tiene a cargo la dicha marca con esta cédula les marca la plata, de lo S. M. es muy damnificado en su real hacienda". ${ }^{14}$ No es frecuente hallar referencia detallada a un procedimiento de descamino de platas tan curioso como el aqui descrito, y por eso hemos recogido "in extenso" la alusión de Juan López de Vicuña a esta marca que pide se destruya.

En I62I, Arregui cita junto a San Sebastián los minerales de Plomosas, "mas ya las minas y la villa están ya casi acabadas". Es significativo que en esta descripción figure Maloya como simple pueblo. ${ }^{15}$

\section{LA PRIMERA RIQUEZA AGROPECUARIA}

Contando con un subsuelo rico, o que al menos se suponía así, el noroeste de México padecía condenado a no poder lograr nunca su prosperidad por la inseguridad del país y la pobreza de sus habitantes. $\mathrm{Y}$ en estas circunstancias el primer incremento de riqueza que podemos advertir se produce en el campo de la ganadería, donde en principio no se hubiese esperado, visto que nada parecía anunciar la existencia de un mercado consumidor apreciable. Sabemos que el país, hasta Sinaloa, era poco apropiado para el desenvolvimiento del ganado, y así se lee de Culiacán: "no hay en esta provincia ni se dan ganados mayores de vacas, ni menores de ovejas, por el gran calor de la tierra"; ${ }^{16}$ y de

14 "Segunda memoria del parecer de la población de la California... por el capitán Juan López de Vicuña". México, 25 mayo 1629. En "Autos y declaraciones que por cédula real recibió el Sr. Ldo. don Juan de Alvarez Serrano, oidor de esta real audiencia de México sobre el descubrimiento de las Californias. Año de 1623 " 79 fols. Fols. 19-29. Guadalajara, I33.

I5. Arregui, ro3.

I6 Mota, Ior. 
Sinaloa: "El ganado mayor vacuno dicen se ta escasamente y algo desmedrado, atribuyéndolo a los grandes calores de la tierra". ${ }^{17}$ For eso no deja de extratiar la inesperada noticia de Juan López de Vicuna, que visitó esta última provincia en 1520 , al menos: "los padres de la Compafía de Jestís, dice, estan tan ricos que tienen. ganado vacuno y cría de mulas y estancia de coger trigo y una viña que han puesto y una jaboneria y curtidura y zapateria que era de Gispar Alvarez, que por hacer la curtiduría le llamaban por mai nombrea "Curtimenta", y me dijo muchas veces que le valía la zapatería, curtiduría y jabonería, después de costos, tres mil pesos de renta". i's La acotación es valiosa, pues la existencia de esta industria derivada y con tal margen de beneficios es la mejor indicación que podemos tener del volumen de la ganadería que iba formándose en la frontera. Ya en otro lugar había clicho el mismo informante: "En esta provincia de Sinaloa hay mucho maíz y trigo, came de puerco y novillos, trijol y chile, que es todo lo que es menester". in

Los datos se confirman algo después. En T637 el obispo de Durango escribia al rey que, habiendo salido el año antes a visitar su diúcesis, halló que los jesuitas ocupaban ya con sus misiones cien leguas de costas ai norte de Sinaloa, hasta el río Mayo. "y los dichos padres tienen en varias estancias más de cien mil catbezas de ganado mayor, y es tierra nuty fértil y abundante de trigo, maíz, algodón y otras cosas". o Hecha por orden del rey al marqués de Cadereita la oportuna infomación, declararon los padres tener ma sola estancia en la provincia de Sinaloa, que era

I7 Mota, iro. Era imposible labrar la tierra con bueyes porque estos animales se alogaban en el trabajo con el excesivo calor, según el "Apolozético Trefensorio". 160. (Vidl, nota 54). Es singulat que Obregón diga gue en Chimetla se le quedó a Coronado algún ganado vacumo cansado, y que Iberra lo halló multiplicado a su llegada Obresón, Baltasar de: Fistoriu de los descubrimiontos antiguos y modamos de

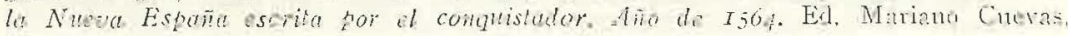
México, то24, pág. т 0.

is Segunda memotia de Vicuna, cit., Guadalajata, I33.

ig "Memoria de lo que ha andado el capitán Juan López de Vicuña". México. 5 mayo r629. En los mismos Autos citarlos, fols. is v.-19. Guadalajara, i3.3.

20 Real cédula de 23 de diciembre $163 \%$. Guedalajarn, 138. 
el Colegio de la villa, y servía para el sostenimiento de este Colegio y de los padres que en él vivían, porque aunque actuaban como párrocos, no llevaban obvenciones a los vecinos, "que es gente pobrísima", ni al presidio; con aquel ganado se socorría también a más de treinta padres repartidos en las misiones, para su sustento y para que lo distribuyeran a los indios. $Y$ con todo, en la estancia del colegio había menos de ocho mil cabezas, y la mayor parte alzadas. "El número de que habló el señor obispo de Durango debe ser el de algunas otras que tienen los pobres vecinos de aquellas provincias y algunos pegujalitos de vacas que tienen los padres en sus partidos para sustentarse de su leche, que en estas partes ni hay restro ni carnicería donde comprar el sustento". ${ }^{21}$

Habían sido los padres quienes de intento habían introducido las reses para contar con este enriquecimiento de su dieta, que tan pobre pintara Urdiñola. Don Francisco de Bustamante, que había sido capitán de Sinaloa, reafirma la cifra y condición de las ocho mil cabezas existentes en la estancia del colegio y cuenta que al principio semanalmente se llevaban algunas a las misiones, pero más adelante, considerando las grandes distancias a que se iba adelantando la predicación, "resolvieron repartir a cada padre y puesto cantidad de treinta o más cabezas para que, cuidando en su partido de ellas como de propio sustento, le tuviese para sí y aún para los propios indios", a los que se repartían con ocasión de fiestas, enfermedades, o hambres. Bustamante ignora el número de cabezas, pero añade que "es muy cierto que se padece y cuesta mucho el coger una res, por ser la tierra doblada y muy dificultoso el hacer rodeos y vaquear el ganado", y al propio tiempo indica no ser conveniente que estas reses tengan salida a otras partes, por constituir - dice con evidente impropiedad- - el único sustento para todos los habitantes de la provincia. ${ }^{22}$

He aquí, pues, sobre estos trazos, cómo se había producido

2I Informe de la Compañía sobre Sinaloa. México, I 2 septiembre I638. En testimonio remitido por Cadereita, fols. 3-22 v. Guadalajara, I38.

22 Informe de don Francisco de Bustamante, México, I8 febrero 1639. Ibid.. fols. $57 \mathrm{v} .-65 \mathrm{v}$. 
la difusión del ganado vacuno en Sinaloa, y cómo se había putesto mua de las bases de la futura riqueza de la Compañía en esta provincia y la de Sonora. E1 problema que de ello se originará, tan controvertido y espinoso, será analizado en su momento. Baste considerar ahora el hecho que acabamos de presentar como un vercladero regalo de primordial importancia de los misioneros al noroeste de México.

Pero el obispo don Alonso Franco y de Luna y los padres tocan otros extremos, los que aluden a la agricultura, que no interesa olvidar. Según el prelado, Sinaloa era tierra muy fértil y abundante de trigo, maíz, algodón y otras cosas, todo lo cual administraban los religiosos con el trabajo de los indios; palahras éstas que inconscientemente, sin malicia, están adelantando casi en medio siglo uno de los más fuertes argumentos en la polémica con los jestitas: la tierra es rica y los padres la dominan, explotan y controlan a través de stus neófitos indios que proporcionan el trahajo. Ahora, en esta fecha temprana, los misioneros se limitan a establecer que no hay ni ha habido en Sinaloa más que frijol, naíz y calahaza y algunas otras semillas y legumbres, y todo en poca cantidad y con muchas esterilidades, durante las cuales los indios se iban a los montes a cazar venados y coger raíces. En ocasiones, los padres habían hecho venir bastimentos de fuera de la provincia. "Trigo, en más de sesenta años del descubrimiento de esta provincia no se dio ni sembró, y se sustentaron los padres con tortillas de maíz, y la harina para las hostias se traía del valle de Santa Bábara". Luego, se sembró un poco, no habiendo tierras a propósito, ni arador, ni bueyes. Algodón no hay: los indios visten de pieles y yerbas, porque se coge poquísimo a causa de las heladas. Los padres "tal vez animan a los indios a que hagan alguna milpilla de maíz, cosa de muy poca consideración y en pueblos cercanos a la villa clonde hava alguna salida del maíz, y aún esa si llega el tiempo de la hambre, ellos se lo comen y consumen". Del trigo dice Bustamante que era sólo para las hostias, y del trabajo de los indios, que era forzosa "el labrar una milpa de comunidad para socorrer 
los reparos de sus iglesias, y ordinario a ellos mismos para su propio sustento".

Los padres, que tal vez no conocieron el pensamiento de Juan López de Vicuña citado más arriba sobre su riqueza, probablemente sí que se mantuvieron en guardia desde el momento del informe del obispo de Durango, para lo sucesivo. Por su parte, llegado el momento de informar a España, el virrey Cadereita pudo agregar a los documentos remitidos la petición del procurador general de la Compañía P. Alonso de Rojas, para qute se abonasen a ésta 5.708 pesos 7 tomines que le adeudaba el presidio de Sinaloa en concepto de compras de géneros de vestuario y bastimentos hecha por los soldados al colegio de la villa, que representaba que la demora en la liquidación de este dinero le causaba gran daño "por tenerlo suplido muchos días ha de lo que los religiosos de él han de menester para adorno del culto divino y para sustento y vestuario, que si no fuera por los socorros que el dicho colegio hace a los dichos soldados de maíz y carne y otras cosas, no pudieran. sustentarse, porque no hay en la dicha provincia otra parte de donde puedan socorrerse sus personas y familias, como consta por certificaciones del capitán don Alonso de Contreras, caballero del orden de San Juan, que lo fue de dicho presidio". ${ }^{23}$

De ello deducía Cadereita ser indudable la utilidad que los padres tenían en Sinaloa, "pero yo no tengo por malo esto, antes me parece bien que hayan poblado haciendas aunque ocupen algunos indios, porque además de que en partes tan remotas es conveniente al bien público, se van enseñando aquellas gentes, que por su naturaleza aborrecen el trabajo, al útil que con él se alcanza, y entablando el gobierno como en las demás partes". ${ }^{24}$

Tal vez estas consideraciones satisfacieron sobre tales puntos al Consejo de Indias, y al rey, cuya resolución u1terior desconocemos.

23 Testimonios remitidos por Cadereita, pieza 2.a, 2 fols. Ibid,

24 Cadereita a S. M., M'éxico, 28 febrero 1639. Guadalajara, I 38. 
La "Memoria de to que ha andado el capitán Juan López de Vicuña", primera de las dos que formó ell r 629, "25 pone a 11uestro alcance la comprensión de lo que era la costa de las provincias del norocste de México para la navegación de cabotaje de la época, que las recorría principalmente en su ruta hacia California. "Luego - dice el capitán, deịando ya atrás las playas de Nueva Galicia-está el río de Acaponeta; es costa de muchos bancos de arena. Aquí se coge mucho camarón. Luego está Chianetla; sale un río grande a la mar. Aquí están las salinas de Su Majestad. Luego está Mazatlán; allí hay unas salinillas. De aquí se atraviesa a la California, que con vela latina se suele ir en veinticuatro horas y vuelto en otras tantas. Luego entra el río del Carrizal; es río grande $y$ hay algunos puertos de la costa de la provincia de Culiacún. Es la costa acamellonada hasta el puerto del Marqués. Hay ríos muy grandes. Cógese aquí mucho ostión, y es el trato de aqueIla provincia. El mejor puerto de esta costa es el puerto del Marqués. No pueden entrar naos grandes, sino fragatillas y barcas: a la boca está isla de Mulas...; luego están otras dos islas pegadas a tierra: son comederos de perlas. Aquí entra la provincia de Sinaloa, es muy grande y muy rica la costa; tiene once islas, y en ellas clescubrió Gaspar Alvarez de nación portugués, el año 20 dieciocho comederos de perlas... Luego entra el puerto de Nuestra Señora: aquí pueden entrar navíos grandes. Entra en el río grande que pasa junto a Sinaloa, su villa. Luego entra el puerto de San Ignacio, y de uno a otro por mar, doce leguas. Aquí entra el río que pasa junto a Carapoa, que es el presidio. Es el puerto muy fondable, pueden entrar navíos de novecientas toneladas. Está este puerto de San Ignacio en 29 grados, pasado por Gaspar Alvarez, que era marinero y tenía astrolabio. Esto es lo que pasa por esta banda. Está poblado: las poblaciones de los indios de toda la costa desde el cabo de Corrientes están la tierra adentro

25 Datada en 5 de mayo. Guadalajara, I 33. 
seis leguas el más cercano a la mar, y los de los españoles de veinte a veinteséis leguas".

López de Vicuña no cita el puerto de Mazatlán en cuya vecindad se hallaba el pueblo de mulatos del mismo nombre, al que sí alude, que era sin duda el mejor de toda Chiametla: este puerto "se hace de un promontorio y de $11 n$ gaje de serranía que se mete tres leguas la mar adentro, haciendo vuelta y ancón otra vez hacia la tierra, de sterte que deja una muy segura ensenada en que pueden surgir mucha cantidad de naos". Puerto y costas se hallaban despoblados, y eso había permitido al pirata inglés Thomas Caldrens - Cavendish- fondear en Mazatlán aguardando la llegada de la nao "Santa Ana" de Filininas, que capturó a fines del siglo XVI. ${ }^{26}$

Son curiosas las palabras de Vicuña sobre la costa de Culiacán, de la que dice Arregui 27 que no sabe haya puerto en ella. De todos modos, a1 menos en los primeros años del siglo era conocido el de Guayahal, que aquél conoce como puerto del Marqués, pero que recibió este otro nombre por un gran bosque de guayabos que ocupaba stus orillas: y si no tenía utilidad alguna, ello se debía a su apartamiento de la ruta de los galeones de Filipinas, por lo dentro del Golfo que se hallaba. ${ }^{28}$

Por último, en Sinaloa hallamos dos buenos fondeaderos. A doce legruas de la villa, a medio camino de la de Culiacán, estaba el de Baihachilato. una gran bahía de más de catorce leguas de circuito, con muchos ostiales. $Y$ en la desembocadura del río de Sinaloa -el primer río de Sinaloa, o de Carapoa o del Fuerte, nombre que al cabo prevaleció- el puerto de San Ignacio o de Torovaca, donde Francisco de Ibarra había fabricado dos navíos, incendiados por los indios antes de haber sido lanzados al agua, episodio que todos los antiguos pobladores de la provincia recordaban a principios del XVII.

La serie de puertos de las costas sinaloenses era de escasa

26 Mota, S9. También cita este puerto Arregui, то3.

27 Arregui, 107.

28 Mota, I06-I07. 


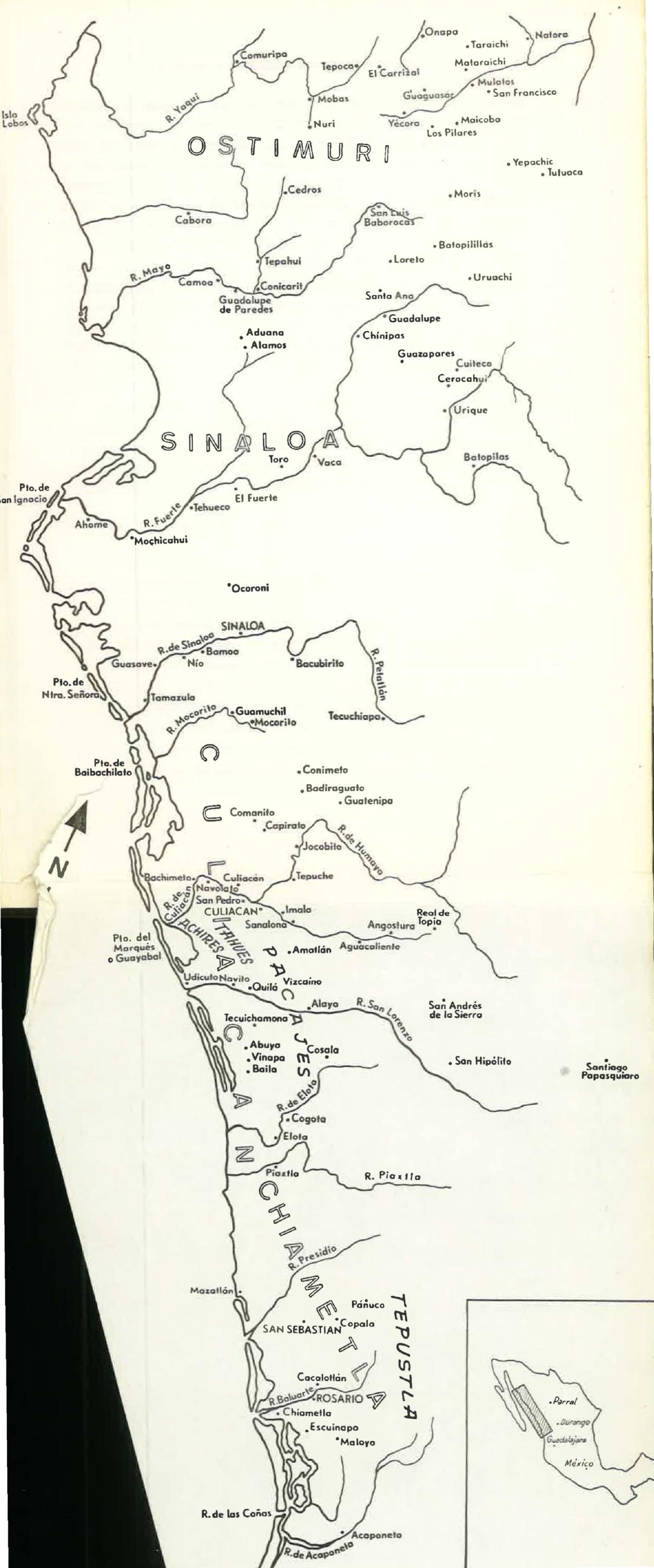




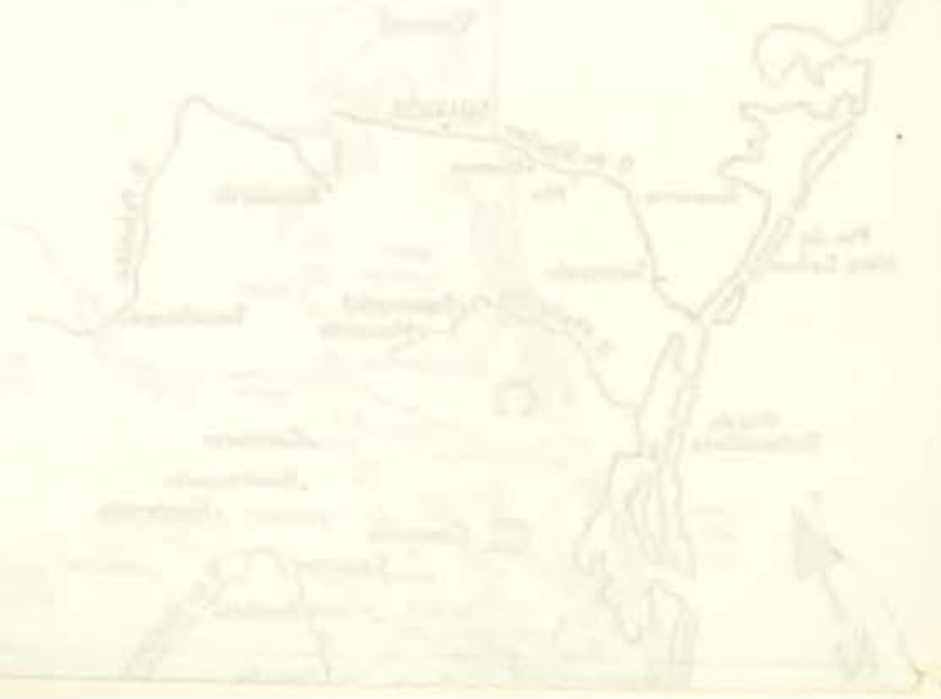


utilidad al país, ya que no eran muchos los barcos que surcaban sus aguas, ni frecuentes las empresas marítimas, que sólo de tarde en tarde se acometían con objeto de buscar perlas no tanto en las costas continentales como en las de la península de Califfornias. ¿Qué otro móvil podía dar lugar a un verdadero tráfico marítimo a lo largo de las desiertas playas del actual Estado de Sinaloa? Las producciones del país no justificaban un intercambio con las provincias de Nueva Galicia, puesto que eran justamente las mismas, ni con Acapulco, El Realejo o Panamí. Sólo un siglo más tarde se darán de ına manera esporádica algunos contactos de esto's puertos. Por otra parte, las necesidades del reducido mercado que ofrecían Culiacán y Sinaloa, principalmente núcleos de población, eran suficientemente atendidas por los mercaderes que acudían desde Guadalajara o Durango. Las costas serán, pues, para el noroeste de México en esta etapa histórica un puro accidente geográfico a espaldas del cual se desenvuelve la vida de las provincias que sólo toman conciencia de su proximidad al mar al aparecer un pirata - cosa no muy frecuente en estas latitudes-, cuanclo se convierten en punto de partida y aprovisionamiento de alguna expedición a Californias.

E.t. BUCEO DE PERLAS y LAS PESQUerías

Ya hemos dicho, por boca del capitán López de Vicuña, cómo en la costa sinaloense había cierto número de "criaderos" de perlas, y en alguna ocasión se citan otros situados sobre la misma orilla, muchas leguas más al norte, en la región llamada de Tepoca. En realidad, ninguno de estos criaderos debía ser de explotación provechosa, a juzgar por el escaso interés que se les prestó. Más atractivo ejercían sobre los aventureros los conchales de Californias, que dieron lugar a una serie de navegaciones, probablemente algunas más de las conocidas, hacia la península vecina. Tales buscadores solían tocar algún puerto del continente, en los de Sinaloa de preferencia, por ser más cercano a su objetivo, y 
porque Sinaloa les podía ofrecer algunos bastimentos más variados y apetecibles que los de Culiacán.

Los informantes de Urdiñola en 1603 todavía recordaban ${ }^{29}$ que veinticuatro o veinticinco años atrás había entrado en el Guayabal un barco de un tal Perálvarez en compañía de otros llamados Sant Remo y Almendral, y de allí vinieron a recorrer las islas de Ahome, a quince leguas de la villa de San Felipe y Santiago, donde embarcó el vecino Pedro de Robles, que pasó con ellos a California, donde hicieron sus buceos, volviendo luego. Es esta la primera expedición conocida a California con fines puramente crematísticos y que tuvo lugar en fecha anterior a I $_{580}$. Doce años más tarde de la visita de Urdiñola, en I6:I5, tocaban: en el puerto de San Ignacio, ya en Sinaloa, Iturbe y Cardona, después de una accidentada navegación en la que había perdido un navío que les capturaron los pechelingues, y de haber estado a punto de perecer con toda la tripulación del otro en el Mar de Cortés por' falta de bastimentos, de no haber tenido la fortuna de hallar este puerto de Ahome, donde los socorrió el P. Andrés Pérez de Ribas. Aquí, cuando menos lo podían esperar, les embargó la fragata nombrada "San Antonio Nuevo", el capitán del presidio Martínez de Hurdaide, que tenía orden del virrey marqués de Guadalcázar de enviar aviso a las naos de la China para anunciarles la presencia de enemigos en las caletas de la península, ocultos así con propósito de sorprenderlas. Iturbe realizó esta misión, y escoltó felizmente a la nao hasta Acapulco, llevando a bordo al capitán Bartolomé Juárez, del presidio de San Hipólito, con alguna tropa. Después Iturbe entró en el puerto de San Ignacio, poco distante del río de Sinaloa, y fabricó alli "otro barcón grande", al decir del jesuita. 30

29 Respuestas a la pregunta 9.", Guadalajara, 28.

3o Venegas, Miguel: Noticia de la California y de su conquista temporal $y$ espiritual hasta el tiempo presento, sacada de la historia manuscrita, formada en México, ar̆o de 1739 . Madrid, 1757. Reimpresa en México, 1943, págs. 150-15t. Pérez de Ribas, y Andres: Triunfos de Nuestra Santo Fe, México, 1944, 3 vols. 1, 300. "Recaudos que se han hecho en el puerto de San Ignacio, costa de la mar 
En 1632 son Ortega y Carbonell, otros bien conocidos buscadores de perlas, quienes igualmente de regreso de la península entraron en la rada de Baibachilato, y acercando la nave a tierra y dejándola cubierta por un jacal para protegerla del sol y del agıa, se dirigieron a la villa, donde el entonces capitán del presidio don Pedro de Perea les ofreció auxilios que les permitiesen continuar los buceos en la costa frontera. ${ }^{31}$ En esta época eran de cierto provecho tales viajes, que se multiplicaron después que Iturbe se había presentado en México con una sorprendente colección de perlas, aunque dañadas en su mayoría. "Varios vecinos de la costa de Cullacán y de Chiametla empezaron a acudir en pequeños barcos a la costa de la California, y a buscar los placeres, y a rescatar las perlas de los indios". "Hiciéronse ricos con este trato algunos pocos de aquellas costas, y entre ellos hay singular memoria de un Antonio del Castillo, vecino de Chiametla". 32 Lástima que estas últimas noticias no pueden ser conocidas con mayor extensión de la que ofrecen las acotaciones transcritas. Tas navegaciones posteriores a las de Ortega y Carbonell, como las anterinres de éstos y de Iturhe no pasan de lo episódico para la historia de Sinaloa.

En la propia costa de esta provincia, en las once islas qute la contornean, había descubierto Gaspar Alvarez en I620 dieciocho "comederos" de perlas, y acudió a registrarlos a México ante el virrey Guadalcázar y no osó ir a pohlar por los recuentos que tuvo con el capitán Martínez, que por su mala lengua lo quiso ahorcar". 33 En realidad nada sabemos de verdaderas pesquerías de perlas practicadas en aguas sinaloenses, lo que no obsta para

del Sur de la provincia de Nuestra Señora de Sinaloa, sobre el embargo de la fragata que se embarcó para ir en busea de las naos de la Chína para darles aviso de In armada del enemigo holandés", 4 fols. Gradalajara, 133.

31 "Relación del viaje de la California, hecho por el eapitán Francisco de Ortega y el capitán Esteban Carbonel, piloto del dicho viaje", firmada por Carhonel Valenzuela en México, 30 septiembre 1632, En los Autos hechos por el oidor A1varez Sertano, fols. 63v-75v. Guadalajara, i 33.

32 Venegas, I5 I.

33 Segunda memoria de Vicuña Guadalajara, I33. 
que con relativa frecuencia se encuentre la alusión a estas piedras entre las riquezas propias de la provincia.

Otra cosa eran las tareas de pesca ordinaria que periódicamente llevaban a cabo los indios de toda la costa con objeto die proveerse de alimento y de practicar algún comercio con el producto sobrante. A principios de siglo había unos cuarenta indios pescadores en la boca del río Chiametla, los cuales, en las grandes mareas de las lunas de noviembre, diciembre y enero de cada año. cuando el mar empuja tierra adentro gran cantidad de peces de todas las especies, en el momento de comenzar el reflujo, echaban rápidamente unos cañizos tejidos de cañas gruesas y fuertes que atravesaban el río entre sus dos riberas y con este artificio obtenían fácilmente una extraordinaria cantidad de pescado, tiburones y salmonetes y mariscos, "que como quedan en seco todo se toma a mano, escogiendo lo mejor, y según que hay la gente y la sal, así sacan la cantidad y aquello que ven que no pueden beneficiar ni salar, alzan el cañizo y lo dejan pasar otra vez al mar; estos lances, como queda dicho, se hacen dos o tres veces al año, en grueso. y préndese tanta cantidad que se provee todo este reino de la $\mathrm{Ga}$ licia y gran parte de la Nueva Vizcaya y Nueva España de pescado cesial". ${ }^{34}$ "La pesquería es - dice Arregui de la misma Chiametla - que en la boca del río, cerca de la conjunción de las lunas de diciembre y enero, suele entrar tanta lisa a desovar que, atajando después el río con unos cañales que para el propósito hacen, suelen coger tanta cantidad que cargan muchas recuas, y se les pierde innumerables arrobas por no lo poder beneficiar todo". 35 La pesquería se daba entre el pueblo de Chímetla y Mazatlán, en Elota, Tabala y Navito, siempre como ocupación de los indios y mulatos. En el último lugar citado se practicaba además con apreciable utilidad la pesca de ostras, de calidad "en extremo buena y grande y de que se proveen todos estos reinos. Tómanla los indios entre peñas y peñascos que hay dentro de este

34 Mota, 87-88.

35 Arregui, I03-I04. 
mar, metidos en él entre la cinta y los pechos, y aungue son grandes estos ostiones, no se les hallan perias de valor...; estan estas ostras grandes, llenas y grasas por los meses de junio y julio, y entonces es la tuerza de la pesquería". $3^{6}$

De nodo semejante al de los más meridionales practicaban la pesca de especies de agua salacia los inclios de Culiacan, aparte que el río de Topia que pasa por la vilia era nuy rico en peces de agua ciluce. Los indios achires pescaban en el puerto de Guayabai. $Y$ en fin, también los de la provincia de Sinatoa se beneficiaban de la fauna actática del pals. 3\%

Sólo sabemos de un español que se interesase por esta actividad, y era el padre Medina, beneficiado de la vilia de Culiacin, dueño de la isla de Mulas en el puerto del Marqués, pero "quitáronsela los Padres de la Compañia, por decir trabajaban mucho los indios, con el corto chinchorro que tenía. Desde entonces perecen. por falta de pescado en aquella provincia, por ser gente pobre". Al menos, esto es lo que dice López de Vicuña. 38

\section{LAS SAIINAS}

Liegamos a la fuente de riqueza mís constante de las antiguas alcalclías de Sinaloa, junto con la pesca a que acabamos de referimos. Mota, Arregui, Urdinola y López de Vicuna, de cuya mano hemos venido recorriendo el país, nos prestáán una vez más la pluma -sobre todo el gobenador-para entrar a conocer esta cuestión. La sal era un ingrediente imprescindible en el proceso de patio para beneficiar la plata, aparte de su utilidad para preparar salazones de pescados que asi conservados se llevaban a los mercados del interior. Segín West --que añade las salinas de Ahome en el río Futerte, en explotación antes de i6r6---, sólo en casos de baja producción de las salinas del desicrio, desde Peñol Blanco al valle de las Salinas de Nuevo México, se recurría a los

36 Mota, 9.2 .

3) Mota, 100, 106, I07.

38 Segunda memoria, Guadalajara, 133. 
depósitos costeros para atender a la,minería de la vertiente oriental de la Sierra Madre. 39 Nuestras fuentes parecen indicar otra cosa. "Lo primero en el distrito de esta gobernación hay las salinas de Chiametla, Piaxtla y Mazatlán, y éstas caen en la marisma y costa del mar del Sur, y además de estas hay noticias ciertas que en la misma costa adelante, en la provincia de Sinaloa, hay muchas partes donde la naturaleza sin beneficio ninguno cuaja gran suma, de sal, y todas estas salinas referidas son a las vertientes de las serranías de San Andrés y Topia a la mar del Sur... La cantidad de sal que se coge en la salina de Chiametla un año con otro poco más o menos es de seis a veinte mil fanegas, que es la que se puede gastar y distribuir en aquella provincia, de la cual se saca en recuas de particulares a quien se vende en los almacenes de V.M. a precio de a ocho reales cada una fanega para provisión de once a doce reales de minas que caen en el distrito y gobernación de la Nueva Galicia, y alguna cantidad para las minas de Maloya, Panuco, Topia, San Andrés, Guanacevi y haciendas de Juan Guerra, y todas éstas están en esta gobernación, y aunque en esta salina hay disposición para coger la sal que quisieren hasta en cantidad de cien mil fanegas en buenos años, no se beneficia ni coge porque no se gasta más cantidad de las dichas siete mil fanegas, y sería la costa y trabajo sin ningún efecto".

"En las del río de Piaxtla y Mazatlán, que son unos esteros pequeños, en los años buenos se cogen de doscientas a trescientas fanegas de sal, las cuales se consumen en los salarios de los alcaldes mayores de estos puestos, por no haber en ellos tributo de naturales ni otras cosas que pudiésele señalar, y así no son de consideración".

"Por manera que el aprovechamiento de todas estas salinas se reduce al que hay de la de Chiametla, que como está referido en ellas se benefician un año con otro de seis a siete mil fanegas, cada una de las cuales estoy informando que tiene de toda costa

39 West, Robert G.: The mining community in northern New Spain: The Parral mining district. Berkeley, 1949, págs. 36-37. 
de cuatro a cinco reales poco más o menos. Y dándose a los mineros de aquella provincia a seis tomines para el beneficio de la plata, y a los arrieros que la sacan para vender en los reales de la Galicia a ocho reales, el aprovechamiento de difiero es poco, el cual no puedo certificar a $V$. M. porque hasta ahora ha estado la administración de la sal a cargo de los oficiales que habia en aquelia provincia, que por orden del virrey de la Nueva España conde de Monterrey fueron quitados, los cuales llevaron los libros de su cargo para dar cuenta a la real contaduria de la ciuclad de México, donde están. Y el alcalcle mayor, a ctyo cargo es ahora, no ha dado cuenta de su tiempo porque el tomarla de la hacienda de Vos ha sido a provisión del virrey de la Nueva Espana".

Hasta aqui algunos párrafos de la interesantisima carta con que el gobernador don Francisco de Urdiñola daba cuenta al rey, el 26 de abril de I605, de las salinas existentes en Nueva Vizcaya, obedeciendo una real cédula de 3 de julio de rooz que así lo disponía, 40

Antes de estas fechas, Rodrigo del Río de la Loza había comu-. nicado que las salinas de Chiameila producian al erario unos dos mil pesos anuales y cubrían las recesidades de las minas de Nueva Galicia y Nueva Vizcaya. 4 I Sin duda que las de Chiametla eran las más importantes de toda la región. Iópez de Vicuna las cita en la descripción de la costa ya conocicla, clonde califica de "salinillas" a las de Mazatlán, con harta razón según se ve por las palabras de Urdinola. Por cierto que también las había en Culiacén, aunque la doctmentación que de ellas nos ha llegado corresponde sólo a los años de $1672-1674$.

En cuanto al volumen de producción de Chiametla, el obispo Mota se limita a decir que "la fana común es que se cogen catia años de doce a quince mil fanegas", $4=$ estimación que dobla las

40 Urdiñola a S. M., Nueva Vizcaya, 26 abril I605. Guadalajaria, 7. Acuse de recibo de la real cédula de 3 juilo I603 por Urdiñola, Durango, t abril 1604 . Gutidalajara, $2 \mathrm{~S}$.

it Rodriso del Río de la Loza a S. M., Duraugo, \& noviembre r 5022 Gue!dalajara, 28.

42 Mota, 86. 
cifras más prudentes del gobernador. Aun es más elevada la que ofrece Arregui, si bien es verdad que escribe veinte años más tarde que aquéllos, y se expresa en estos términos: "Todo lo que en esta provincia hay notable es las salinas y pesquería de Chiametla. En la marisma están las salinas, que se benefician haciendo unas erillas donde el agua que entra de las mareas se cuaja y suélense hacer de esta manera algunos años 20.000 fanegas de sal, y juntándola la acarrean con recuas al pueblo a unos almacenes, pagando por cada carga cuatro reales, y después la de S. M. a peso, en, que debe de interesar poco". 43 Precisamente Arregui recoge también el dato de las salinas de Navito, en Culiacán, aunque asegura que no se coge, ni con mucho, tanta sal como en Chiametla. 44 Urdiñola, por su parte, en su tercera carta sobre este tema, repite la noticia de que los esteros del puerto de San Juan de Mazatlán se benefician poco, y en Piaxtla sólo se saca para pagar al alcalde mayor, que tiene a su cargo los naturales de la comarca. $Y$ añade ahora que las muchas salinas de Sinaloa no se benefician "por estar tan a trasmano y no haber saca de ella para parte ninguna", aunque desde luego se podría conducir en barcos a Nueva Galicia y otras partes del mar del Sur. 45

Ciñámonos, pues, a hablar de las de Chiametla, sin perjuicio de que más adelante toquemos las de Culiacán. Chiametla proporcionaba la sal más fuerte, mejor y más barata con que, con poco gasto, se trabajaba en todos los reales de minas de Nueva Vizcaya. De mucho tiempo atrás - probablemente desde los de Ibarra- estaban las salinas en administración real encomendadas al alcalde mayor de San Sebastián, conservándose la sal en un almacén construido a tal fin, al que venían a comprarlo los arrieros. Para recogerla de las orillas se sacaban y reunían hasta mil indios chichimecos serranos y de poco asiento, a los que no se podía apremiar con rigor, sino que se traían por ruegos y con suavidad. Un comisionado, con título de veedor, estaba especialmente encar-

43 Arregui, 9I-92.

44 Arregui, 93.

45 Urdiñola a S. M., Parras, 6 abril I607. Guadalajara, 28. 
Gado de esta tarea y la de dirigir las labores de la "cosecha". En tiempos del alcalde nayor clon bartolomé de Mesa, a quien Urdiñola hizo tomar las cuentas 46 desempeñaban esta función, alternativamente, Diego Ortiz y Rodrigo de Vera. El "cargo" de la sal de Mesa es muy sencillo:

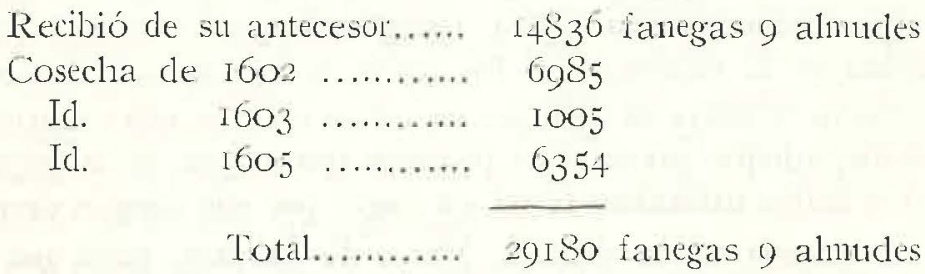

No puede ser más patente la desigualdad de mas cosechas con otras, de un año al siguiente, y todavía en sólo cuatro años hubo two en que no se cogió absolutamente rada. El promedio de las tres cosechas es de 4784 fanegas, y el clel cuatrienio se reduce a 3586, cifras ambas bastante lejos de las anumciadas por Urdiñola. Del total de gute se hacía cargo, vendió Mesa 19961 fanegas 9 almudes, y se le aceptó como clatá en concepto de merma de la sal la cantidad de hasta 1022 fanegas; d negocio no parecía muty floreciente, ni muy crecida la demanda, annque sus exeedentes - Sig7 fanegas- fuesen más bajos que los que recibió. De la sal vendicla, parte a 6 tomines y parte a 8 reales, se habían percibido I 8777 ps. 3 tomines. Como los gastos de beneficio, almacenaniento, salarios, etc., ascendían súlo a 8355 ps. 4 tomines, 6 granos, quedaba un margen de ganancias de 10379 pesos 5 granos, del que sólo había que descontar ya el salario del propio alcalde mayor, a razón de 300 ps. antiales. Las cuentas de i602i 605 hacen, pues, verdadera la evolución de dos mil pesos de beneficio antual para la real hacienda cute hacía Rodrigo del Río de la Loza, y acentúan las palabras de Urdiñola de que, aun cuando

46 Certificación de lit cuenta tomala a Mesa en it noviembre 1606 , que acompaña a carta de Uirdinola últinamente citala. 
las salinas podían producir más - lo que aquí parece dudosu--no tendría salida su producción. El interés del rey era, después de todo, muy corto, aunque ganado con escaso esfuerzo, : st multiplicaba luego en forma de quintos, derechos de las platas, etc. Se advierte que la sal vendida a 6 tomines, para el consumo interior, ascendia a 4737,5 fanegas, mientras que la que se sacalba de la provincia sumaba 15224 fanegas. Imposible saber, por lic vaguedad de la expresión, si los reales de la sierra y el interior a de Nueva Vizcaya se incluyen en una u otra de estas cantidades y precios, aunque parece más probable que vayan en la seguncla. Sólo los indios utilizaban la sal sin pagar por ello ningún derecho.

Su sucesor en la alcaldía, Mateo de Barrasa, tuvo una primera cosecha prodigiosa: en I 606 no llovió en las salinas y los vientos y la mar fueron favorables, los esteros se cuajaron $\sin$ beneficio y con sólo recoger la sal se obtuvieron 25227,5 fanegas. Sumando lo que había dejado Mesa, había sal para más de cinco anos, con un valor total de 23.000 pesos, según las previsiones de los que el rey podía percibir buena parte. 47

Los informes de Urdiñola habían tendido a mostrar la conveniencia de que las salinas continuasen en administración. ¿Cući no sería su sorpresa al recibir en México la real cédula de $2 \delta$ de agosto de 1604 para dejar libre el uso de la sal, $4^{8}$ suponiendo que el anterior estado era perjudicial para los indios? Urdiñola replicó defendiendo el estanco. "Hoy tengo almacenadas y costeadas más de cuarenta mil fanegas de muy rica sal" que se vendía a los mineros al acomodado precio de ocho reales fanega, sin que se causase a los indios el menor daño, por lo cual había dejado suspensa la ejecución de la cédula, hasta informar al rey de esto, como lo había hecho ya al virrey. 49 No obstante, pocos meses des-

47 Ibid.

48 Guadalajara, 28. La cédula de 4 abril i609 a Urdiñola (Guadalajara, 23心́, 22 , fols. 125v-r26v). se limita a aprobar a éste que no se apremie a los chichimecas de Nueva Vizcaya a trabajar las salinas.

49 Urdiñola a S. M., México, 25 mayo I6ri. Guadalajara, 28. 
pués una segunda cédula de 3 de septiembre de r6r r vino a ratificar la decisión real. ${ }^{\circ}$

No consta el cumplimiento de esta nuteva disposición, y es obvio que continuó la administración, por cuanto así lo informa López de Vicuña en I629, añadiendo que los alcaldes mayores la habian convertido en granjería propia, evitando tener que presentar cuentas o dándolas de modo que viniesen ellos a quedarse con todo el producto de las cinco o seis mil fanegas de sill que se cogían anualmente y se vendian a seis reales para la provincia y a ocho para aftera. Los dos Gurrolas y Gregorio Medrano eran acusados de aquella irregularidad.

En Culiacín, como en Chiametla, la explotación de las salinas estaba a cargo del alcalde mayor, pero de sus actividades a este respecto súlo nos han llegado las cuentas de i672-I673. Lo más interesante es, sin duda, la reparación de las salinas realizada este este último ano, después que en i6ri se habían anegado de resul-. tas de una intundación. "En términos del pueblo antigno y despoblado llamado Atanura había roto y hecho corriente el río que llannan de IJunaya de manera que se derramó hasta las reales salinas, dejando en ellas mutrcha palizada, arena, horruras, que en semejantes crecientes acontece". Calderón, entonces justicia nuyor de la provincia, lo avisó a los oficiales reales de Guadalajara y éstos pasaron la noticia al virrey, quien con vista oficial y de junta de real haciencla ordenó en 17 de marzo de 1672 que aquéllos comisionasen una persona que atendiese a poner las salinas en estado de producir su cosecha. Entonces, "para que el dicho rio cogiese y tomase su antiguro curso y corriente, se hizo en el dicho derrane una estacada como dos brazas de ancho, llenándola de fajina y terraplenándola, cual tendrá cincuenta o sesenta brazas de largo, y asinismo se le hicieran clos zanjas de un estado de alto para que tomase por alli boca y corriente el clicho río, y los esteros y marismas de las reales salinas se limpiaran de la inun- 
dación que dichas corrientes dejaron, habiéndolas dejado limpias y con perfección para que, siendo Dios servido, se coja sal". ${ }^{5}$

He aquí el rendimiento de las salinas de Culiacán, según las cuentas de Calderón. ${ }^{52}$

Recibió éste de su antecesor........... I600 fanegas

Cosechó en $1672 \ldots \ldots \ldots \ldots \ldots \ldots \ldots \ldots . \quad 720 \quad " 6$ almudes

"

1673 $1600 \quad "$

3920 fanegas 6 almudes

Entre la "data" había por fuerza de destacar, en primer lugar, la pérdida producida por la inundación, que se calculaba en I 3 I2 fanegas, 6 almudes.

Ventas de 1672 .................... 287 fanegas 6. almudes

Ventas de 1673 $720 "$

Eintregó Calderón a su sucesor......... I600"

El alcalde mayor vendía la sal a sólo 4 tomines fanega, de suerte que el millar largo vendido sólo había valido 493 ps. 4 tomines, con lo que, pagados los gastos de la reparación de las salinas, no quedaba cubrir el importe de los salarios del propio Calderón. La hacienda, por tanto, no se beneficiaba con estas salinas, situadas en los puestos de Cuchina y Agueraguato, y si producían algún provecho era a los que las trabajaban y a las minas que se abastecían de su sal para atender a las labores de haciendas de sacar plata.

Por mayo de cada año, nombraba el alcalde mayor un veedor - en estas fechas lo era Agustín de Mesa-, a quien se daban los mandamientos necesarios para sacar indios con que realizar las faenas de la cosecha. Un mes más tarde el veedor daba cuenta

51 Cuaderno y cuenta de Calderón, fols. 6y.-8v, y 9-10. Guadalajara, I5.

52 Ibid., fols. 20v.-22v, 
de haber levantado ciesto número de montones de sal - siete en t672, el cloble al año siguiente- que quedaban en los esteros "bien acondicionados, golpeados en la forma acostumbrada y que se debe hacer", porque en Culiacán nunca había habido almacén real.

Las cifras insertadas muestran bien a las claras la notable diferencia en el volumen de producción de estas salinas respecto de las de Chianctla. Sin embargo, no eran aquellas las únicas de 1a provincia, porque Mota habla de dos - Natoato y Udicuto-.. junto a Navito, a seis y ntteve leguas de la villa de Culiacán, y una tercera a quince leguas de ésta. 53 La sal cle las primeras se pagaba en Nieva España hasta a seis y ocho pesos la fanega, y se cogían gunce mil fanegas cada año. Todas tres se administraban de cuenta del rey cuando Mota visitó la provincia. $Y$ sin embargo, los datos de I672-I673 sólo se refieren, al parecer, a la tercera salima, situada en la boca del Humaya.

\section{UN NUEVO "NORTE MINERO"}

Alorín ticmpo después del asentamiento en el valle de Sonora de los pobladores conducidos por don Pedro de Perea, tal vez hacia 1650 , habían empezado a ser explotadas algnnas minas en la nueva provincia. E1 "Apologético Defensorio" de 1657 5t habla del mineral de San Pedro y de otros "realejos" de escasa importancia, que en total no pasaban de cuatro o cinco. Probablemente nada hacia sospechar que acababa de nacer un nuevo "norte minero" como sucesivamente to fueron Zacatecas, Parral y Chiluthua, que atraería una apreciable cantidad de buscadores y comerciantes y abriría nuevas vías de prosperidad para Sonora misma y para todo el territorio a sus espaldas. Por aquellas mismas fechas habíase también reactivado el potencial minero de la antigua Chianetla: un nuevo real ha surgido ahora en el distrito de la alcaldía de

\footnotetext{
53 Mota, I03-104.

54 Herrera Carrilio, Pablo: Sinaloa a mediados del siglo XYII. Uil documento de estraordinaria importancia, el "Apolngétio Defusorio". En "Memorias y Revista die! Congreso Mexicano de Historia". I, México ig6e, paigs. 145-174.
} 
San Sebastián. Este real cle San José de Copala llevaba a quintar sus platas a la Caja de Guadalajara. 55 Algo más meridional ha nacido otro real, el de Nuestra Señora del Rosario, que ya tenía nombre a mitad de siglo. Copala, Rosario, y los recientes desc11brimientos de Sonora dan razón del ange que las alcaldías costeras experimentan después de i 6,50 . Tras una prolongada depresión, el motor de la expansión - los hallazgos mineros - ha sido puesto de nuevo en marcha.

El principal centro de la explotación argentífera de Sonora se encontraba en la capital de la provincia, en el real de San Juan Bautista. No mucho más tarde, hacia I666, tenía lugar el descubrimiento de plata en San Miguel ${ }^{56}$ y dos años desputués, en r668, surgía el real de los Gentiles o de San Ignacio de Ostimuri y San Marcos. La región de San Miguel parecía muy abundante en metales: antes que el propio real de este nombre, que fue de los últimos en descubrirse, se habían hecho ya otros hallazgos. Había minas en Santa Bátbara - donde se encontró oro- y en Banachare, en Santiago de Tuapa, y en San Francisco del Yaqui. 57 Ostimuri - la franja entre el Mayo y el Yaqui- se mostró pronto rica cuenca minera: los reales de San Ildefonso. San Nicolás, San Francisco de Asís, San Ignacio, Tacupeto, Bocanora y San Marcos estaban en actividad muy poco después de practicado el primer descubrimiento, y se mantuvieron en ella hasta fines del siglo.

Por verdadera fortuna disponemos de una estadística decenal del producto de las minas de Sonora y Ostimuri, que cubre de I675 a I684 y su comparación con los productos correlativos del Parral y sus contornos, en certificación expedida por el escribano Miguel de Aranda. La producción se da en marcos de plata.

55 Guajardo Fajardo a S. M., Parral, 4 mayo 1649. Guadalajara, 20.

56 Patronato, 232, ramo $\mathrm{I}^{\circ}$, fols. 203-206V.

57 Ibid., 247-251v. 


\begin{tabular}{lll} 
& $\frac{\text { Parral }}{1675}$ & $\frac{\text { Sonora }}{13609}$ \\
\cline { 2 - 2 } 1676 & 60357 & $2822 \mathrm{I}$ \\
1677 & 67424 & 13462 \\
1678 & 65548 & 12745 \\
1679 & 69653 & 15477 \\
1680 & 61735 & 14523 \\
1681 & 64357 & 17916 \\
1682 & 64575 & 16603 \\
1683 & 43602 & 18358 \\
1684 & 34930 & 23240 \\
& 47519 & 174154
\end{tabular}

Aranda añade ${ }^{5}$ la producción habida en 1685 , hasta el 28 de marzo en Parral (29802 marcos) y hasta el 22 en Sonora (289I marcos). Agrega el escribano que es realmente difícil a través de los registros discriminar las platas de Sonora de las del Parral, porqute muchas veces no se hace constar la procedencia, y en tales casos, todo se ha sumado a la columnna de la producción de Parral. También es cierto que parte de las platas era llevada a otras cajas: Durango, Zacatecas, Sombrerete. Con todo, puede admitirse que la media anual de Sonora viene a ser una tercera parte de la Nueva Vizcaya, lo cue no es poco, y aún es posible apreciar que mientras la actividad minera de Parral decae desde i68 I, la de Sonora parece incrementarse en 1683 y $168_{4}$.

En estos momentos, la cuenta minera del noreste se amplía con la incorporación de Sinaloa, que ha tardaclo ciento veinte años en encontrar la ricueza de su subsuelo. En I6S3 tiene lugar el descubrimiento de vetas de plata en el cerro de Nuestra Señora de la Concepción de los Frailes. 59 Este real de los Frailes dió paso

5: Certificación de Aranda en Guadalajara, 18.

59 El acta de la junta habida en Alamos el 13 octubre I686 dice que se des. cubrió plata en Frailes "de más tiempo de tres años". Testimonio de autos de 1637 en Gu:!clalajara, i9. 
a la fundación del puesto de los Alamos, lugar donde los mineros establecieron sus viviendas. En I 686, el alcalde mayor don Domingo Terán buscó otro asentamiento para el real a orillas del río Mayo, entre Conicari y Camoa, y allí fundó el que llamó real de Nuestra Señora de Guadalupe y Santo Tomás de Paredes, cle corta vida, pero que él dice llegó a tener veintitrés haciendlas de saca1 plata. ${ }^{60}$

Alamos o Frailes y el también vecino real de la Aduana perdurarán todo el siglo siguiente.

\section{Los Caninos DE LA Costa Y DE LA SIERRA}

Aunque recorrido de sur a norte y de norte a sur por los españoles desde los tiempos de Nuño Beltrán de Guzmán y de Alvar Núñez Cabeza de Vaca, el camino costero, lo que Saver ha llamado la ruta de Cibola, que, saltando de río en río, conducía clescle el de las Cañas al confín de la frontera móvil que a lo largo del siglo XVII se va internando hacia el norte hasta alcanzar los afluentes meridionales del Gila; este camino transitado por mercaderes y recuas de acémilas, y por los correos que enlazaban las misiones y pueblos de indios, las villas de españoles y los reales mineros entre sí; este camino pisado por Niza, Coronado e Ibarra era, en las postrimerías del siglo XVII, si hemos de dar fe a un documento notarial, una vía casi impracticable. El documento en cuestión, verdadera curiosidad histórica, es una certificación dada en la villa de Sinaloa el 7 de febrero de 1699 , cuyo original se halla en el Archivo General de Indias, y dice así:

"Yo, Marcos de Tapia Palacios, escribano receptor propietario del número de la Real Audiencia del reino de la Nueva Galicia por el Rey nuestro señor. Certifico en testimonio de verdad cómo a los catorce del mes pasado de 698 salí c̀e la ciudad de Guadalajara en compañía del Sr. alférez real don Jacinto de Fuensaldaña gobernador político y militar de esta provincia de Sinaloa

60 Testimonio de la residencia de Terán, fols. 73-74. Escribanía de Cámara 390, A. 
y capitán de su presidio por S. M. y capitán general en ella, la de Sinaloa y costas del Mar del Sur y administrador de reales azogues por el Excmo. Sr. virrey de la Nueva España, de orden de dicha Real Audiencia para asistir a dicho Sr. Gobernador en todo lo que se le of reciere en esta dicha provincia hasta que quedase en quieta y pacífica posesión de dicho oficio, quien trajo una familia de veintidós personas, $y$ a su esposa encinta en meses mayores y (una) niña de poco más de dos años, caminando más de doscientas y cincuenta leguas que hay desde dicha ciudad de Guadalajara hasta esta villa, por caminos bastantemente penosos de cuestas y barrancas, muy montuosos, que en la mayor parte de dicho camino fue menester llevar personas que con hachas fuesen desmontando para poder pasar y en otras partes cargando en hombros de gente pagada el forlón en que venía, por la imposibilidad de rodar, agregándose a esto muchas quebradas, atascaderos, pedregales, ríos muy caudalosos, y todo lo más del camino infestado de sabandijas muy ponzoñosas y plagas de mosquitos, y fuera de lo referido ser la tierra muy caliente, el sol muy ardiente y los pueblos que hay en dicho camino de cien leguas adelante de Guadalajara para esta dicha villa tan infructíferos y estériles de bastimentos que no se hallaba en ellos ni aun maíz para el sustento de las mulas en que venia todo el bagaje y necesarios, fletadas a subidos precios por falta total de arancel, ni otra economía en tierras tan despobladas, y llegó dicho gobernador a esta dicha villa el día 5 del corriente habiendo gastado en el camino cincuenta y cuatro dias por la aspereza e inconvenencias de él como queda dicho. ${ }^{61}$

Esto era el corredor costero, en su tramo de Guadalajara a Sinaloa. Nada hace suponer que fuese más cómodo de aquí al norte, salvo una cierta mitigación del calor. La lentitud de la marcha y los crecidos costes del transporte, sumados a las inmensas distancias que había que franquear, hacen así explicables los elevadísimos precios de las mercancias en este rincón de Nueva España.

La costa se comunicaba, de todos modos, con el interior, con

61 Guadalajaral, 154 . 
Nueva Vizcaya, a través también de las sendas que cruzaban la sierra. Tres de estos caminos están documentados en las fuentes. E1 primero $y$ más antiguo conducia de Durango a Chiametla y a Sinaloa por Papasquiaro y Topia y a través de la provincia de Culiacán. Precisamente esta vía fue la seguida por los expedicionarios de Ibarra. Y tal vez fuese esta la ruta a que aluden las probanzas presentadas por don Diego de Ibarra, tío del conquistador, que en I 582 asienta que "especialmente abrió los caminos desde la villa de Durango a la de San Sebastián, por donde antes se despeñaban las recuas" que ordinariamente abastecían a esta última. ${ }^{62}$ Culiacán estaba situada en la boca de esta senda que cruzaba la sierra por Topia, como que el río de Topia es el de Culiacán. Saliendo de la villa de San Miguel hacia el interior, siguiendo dirección opuesta a la de Ibarra, como la llevó Peralméndez Chirinos, a doce leguas se halla el pueblo de Tomo, y dos más adelante el de Guzmanillo, donde acababa la tierra caliente y la misma provincia de Culiacán, y donde empezaban las dieciséis leguas de despoblado por la áspera serranía, hasta Topia. Cuatro jornadas se tardaba en salvarlas, haciendo altos en los parajes de Aguascalientes, el Obispo, Angostura y Pie de la Cuesta. ${ }^{6}$ Cuando los indios de Topia se hallaban inquietos - Mota dice que los caminantes y arrieros españoles eran impunente atacados en aquellas hondonadas en que los caballos no podían ser de utilidad-- era posible alcanzar la costa por otra incomodísima senda que salvaba la sierra en dirección a Acaponeta, y asi lo hicieron los padres Tapia y Pérez cuando fueron a hacerse cargo de la misión de Sinaloa. 64 Pero esta vía secundaria no debía ser utilizada en circunstancias normales.

E1 segundo camino de la sierra, mucho más al norte, corresponde ya al momento en que los españoles han poblado Sonora $y$, en la otra vertiente de la cordillera se ha fundado el real de Parral, porque estos son los puntos terminales de la ruta. Partiendo del

62 Probanza de don Diego de Ibarra, pregunta 14." Guadalajara, 28.

63 Mota, II3-II5.

64 Pérez de Ribas: Ob. cit, II, I6z. 
real de San. Iuzn, el camino cruzaba uta porción de la que sería provincia de Ostimuri - Sahuaripa, Arivechi, Tacupeto- continuaba ciento treinta leguas al oeste, siempre al sur del rio Yaqui y al norte del Conchos, hasta la capital minera de Nueva Vizcaya, por tierras que durante mucho tiempo siguieron siendo de gentiles, hasta que arraigaron las misiones de la Tarahumara Alta, que no empiezan a ser establecidas hasta fines de 1673. Las repetidas sublevaciones de 108 tarahumaras cortaron frectenterente esta vía directa de acceso del valle de Sonora a Parral, por Tutuaca. Tomochi y Cusihuriáchic. Así como sabemos que Chirinos e Ibara había descubierto la ruta Culiacín-Iurango, sabemos quienes fueron los primeros en transitar de Parral a Sonora: unos mineros que, como los portugueses de San Martín en tiempos de lbarra, cruzaron las tierras de los tarahumaras descle las estribaciones orientales de la cordillera hasta los pueblos de Ostimuri. En i GAt el camino quedó seguramente fijado cuando don Pedro de Perea y el jesuita P. Jerónimo Figueroa siguieron el mismo rumbo desde Parral para salir al Yaqui en Sonora. ${ }_{5}^{5}$

El tercer camino de que bablaremos es el que enlaza el rio de Bavispe con la chenca cerrada de los ros de Casas Grandes, Namiquipa y de las Cruces, desde donde se puede descender comodamente hasta Cusihuriáchic. Esta vía quedó expectita despres de I650, cuando quedaron de paz, aunque no cristianizados, los bavispes, y cuando los franciscanos acometieron la evangelización de las parcialidades de indios sumas, janos, conchos y apaches que mediaban entre la sierra y el río Grande del Norte, y se estableció alcaldia mayor en Casas Grandes. Rota 1nego la paz con estos indios, la formación de an núcleo español en El Paso y la erección del presidio en Casas Grandes --Janos aseguraron la rata por la parte de Nuevo México y Nueva Vizcaya, como la formación de la compañia volante, luego presidio de Fronteras, en Sonora. Este

65 Decorme, Gerard: La obra do los jesidas mexiconos durnte la éroca

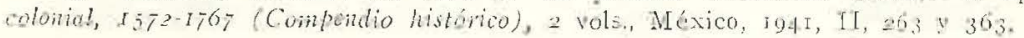


camino Parral - San Juan, más largo que el de las misiones de la sierra, era sin embargo, más cómodo y cobraría mucha más importancia al surgir a principios del XVIII el famoso real del Chihucthua. 


\section{Capírujuo II}

\section{LA POBLACION EN UN SIGLO DE DEPRESION}

Disponemos de documentación hasta cierto punto suficiente para evaluar el número de habitantes de las provinciás costeras del noroeste de México a principios del siglo XVII. Por desgracia no podemos decir lo mismo para los años a partir de i6zo. Faltan desde la cuarta década de la centuria curiosos informantes del tipo de nuestros socorridos Mota y Arregui, o celosos gobernadores al estilo de Urdiñola. Y. así, nos resulta imposible tener el pulso de la demografía de las alcalclías a lo largo de los cien años, lo que no deja de ser enojoso de reconocer cuando se había anhelado vivamente llegar a la comprensión del fenómeno de expansión al norte, de penetración en Sonora, que se produce a poco de cesar el fiuir de nuestras fuentes. Veamos, pues, al menos, lo que éstas indican.

\section{LOS DATOS DEL OBISPO, EN I 605}

Don Alonso de Mota y Escobar nos conduce costa arriba en los primeros años del siglo, desde Escunapa hasta la villa de Sinaloa. Sus datos, basados en la observación directa, son de extraordinario valor, por lo detallados y por el gran vacío de la documentación oficial que llenan. Helos aquí:

Vecinos

Escuinapa

Chiametla

¿Poblezuelo?

Mazatlán

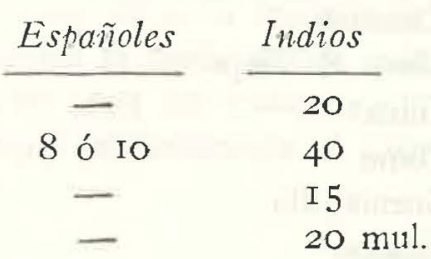




\begin{tabular}{|c|c|c|}
\hline Fecinos & Españoles & Indios \\
\hline San Sebastián & 20 & \\
\hline Panuco y Materoy & $?$ & $?$ \\
\hline Elota & - & 30 \\
\hline Acachán & - & 20 \\
\hline Abuya & - & 20 \\
\hline Tabala & - & $?$ \\
\hline Navito & - & - \\
\hline Villa de Culiacán & 30 & - \\
\hline Hiluruto & - & I 5 \\
\hline Teculimeto & 一 & IO \\
\hline Culiacán & - & I2 \\
\hline Ategualato & - & 25 \\
\hline Yebalito & - & 8 \\
\hline Diariacato & - & 6 \\
\hline Teboloto & - & 8 \\
\hline Nabolato & 一 & I4 \\
\hline Atamura & - & 6 \\
\hline Guachimeto & - & $?$ \\
\hline Itagi & - & I8 \\
\hline Imala & - & 22 \\
\hline Sanalona & - & 34 \\
\hline Ilimaca & - & 7 \\
\hline Amatlán & - & 18 \\
\hline Vizcaíno & - & 20 \\
\hline Quilá & - & 8 \\
\hline Tinola & - & 7 \\
\hline Tepuche & - & 30 \\
\hline Tecorito & 一 & 40 \\
\hline Moro el Viejo & - & 40 \\
\hline Colmo & - & 20 \\
\hline Tomo & - & I 5 \\
\hline Guzmanillo & - & I 5 \\
\hline Sinaloa & $2 \mathrm{I} \mathrm{h}$. & 5.000 \\
\hline
\end{tabular}


Espanta considerar que en toda la extensión del actual estado de Sinaloa no hulbiese más de los isesenta! recinos españoles que recoge Mota en su Descripción, más los veintiún soldados de la villa más setentrional, lo que daría una cifra aproximada de cratrocientos blancos - suponiendo que todos lo iueran puros-- como único fermento de la europeización de aquellas provincias y núcleo dominador de los quinientos diecisiete vecinos u hogares indios, que no harían menos de unos dos mil individtos de esta raza. Y con todo, la impresión dominante es otra, sobre la que acabamos de exponer: ¿Qué enorme desierto eran las provincias! ¿Cómo habían de prosperar así? Los grupos nómadas existentes, siempre por naturaleza insignificantes, en las costas y en la sierra, cuentan aúm menos a la hora de valorar el potencial humano que podía ponerse a la tarea de edificar una civilización distinta sobre el territorio. El obispo Mota nos trae en estas cifras la anonadante certeza de que las alcaldías costeras nada erair, y nada podía esperarse de ellas.

Por supuesto, lá notá dominante es la de la exigüedad de la población de la zona al sur de Culiacán.

Todos los territorios que conprendemos bajo el nombre genérico de Chiametla se hallaban ocupados por unas dos docenas de espanoles y poco más de siete de indios, y los núcleos cuya cifra onite el obispo no alterarían de manera decisiva estos datos. Bien es verdad que Chianctla es región ampliamente recorrida por grurpos nómadas; Urdinola advierte que el trabajo de las salinas lo hacían inclios serranos de poco asiento. Rasgo curioso es la presencia del vecindario mulato de Mazatlán, que Arregui I encontró reclucido a sólo tres o cuatro familias.

Por lo tocante a Chiametla en conjunto, la ínica noticia que podemos añadir es la que proporciona la razón de los inclios que en Nueva Vizcaya administraban en I625 los misioneros y curas diocesanos, y que por su fecha suple perfectamente el silencio de

1 Arregui, 103. 
de Arregui. Dicho documento ${ }^{2}$ asegura que en la provincia de Chiametla y su jurisdicción administraban el licenciado Bartolomé Mexía de Prado y el bachiller Antonio Rubio Félix dos mil doscientas ochenta personas. ¿Quién podría decir si esta apreciable elevación de la población se debe a un mejor recuento de los indígenas o a la afluencia de nuevos elementos españoles y de las castas?

LOS ESPAÑOLES, SEGÚN URDIÑOLA, EN I604

Si de momento prescindimos de la villa de Sinaloa, como parece prudente por la greneral vaguedad con que hablan los informantes, encontramos en Urdiñola una valiosa fuente de noticias por lo tocante a las provincias de la jurisdicción de Nueva Vizcaya, es decir, las correspondientes al territorio de Chiametla, dividido en tres alcaldías - Copala, Mayola y San Sebastián-. A. Urdiñola, por alguna razón, sólo le preocupó saber precisamente el número de españoles, poniéndonos en condiciones de conocer incluso sus nombres. Las relaciones pedidas por el gobernador desde Topia el to de enero de 1604 fueron enviadas en las dos primeras alcaldias y stplidas con informes extrajudiciales en el caso de San Sebastián. 3 Las cifras así alcanzadas son éstas:

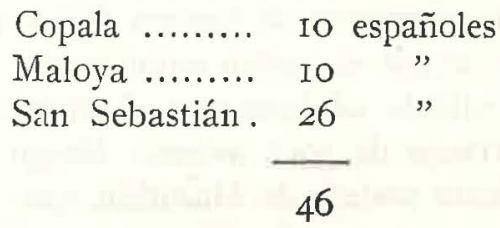

Aparentemente, la cifra de pobladores españoles se ha elevadc en esta relación. Pero no es caso: todo se debe a que Mota nos da

2 Bandelier, Adolph F. A. and Fanny R. Bandelier: Historical Documents relating to New Merico, Nueva Viscaya and Appronches Thereto, to I773. Ed. by Charles Wilson, Hackett, Washington, I 926, 3 vols. II, I 56.

3 Guadalajara, 28. Transcritas en Gallegos C., José Ignacio. Durango Colovial, I563-I821. 1960, págs. 206-210. 
los "vecinos" y Urdiñola los varones españoles, es decir, blancos. He aquí sus nombres.

\title{
Copala
}

Juan de Estén

Mateo Camacho

Rodrigo Ruiz de Olvera

Luis de Cepeda

Matías de Betancur

Francisco López de Sepúlveda

Juan Pérez de Domica

Juan Gutiérrez

Lorenzo Guillén

Baltasar Hernández

Maloya

\author{
Diego Vázquez Mejía \\ Juan Bernardo de Quirós \\ Juan de Bustinza \\ Francisco López de Viera \\ Miguel Fernández \\ Baltasar de Fonseca \\ Juan Martín Corregidor \\ Pedro Burgueño \\ Fernando del Carpio \\ Bartolomé Sánchez Mejía de Prado
}

De estos esforzados pobladores de los reales mineros, seis constan como propietarios o "administradores" de haciendas de sacar plata, los restantes son asalariados de aquéllos, o mercaderes - constan dos- o de otros oficios: sacerdote, maestro de hacer ingenios, arcabuceros, alcalde mayor. Por supuesto, algunos de ellos son tan sólo estantes, no habitantes de los reales. 


\section{En Son Sebastián}

\section{Diego López de Velasco \\ Cristóbai Rodriguez \\ Pedro de Cañizares \\ Francisco Rodriguez Bayón}

Anclés l_ópez

Juan Fernando Barrón

Diego Ortiz

Diego Maldonado

Juan de Costa

Antonio de 'Tejeda

el yerno de Juan Zapatero

Diego Sálnchez

Juan Ríos Parrá

Pedro Martín de Llanes

Martín Ruiz de Astirre

Juan Fernández

Pedro de Gaica

Francisco de Orozco

Francisco Rodríguez

Diego de Verber

Marcos de Lanra

Juan Zuro

Cristóbal Sánchez

Francisco López de Velasco

Juan Alvarez

Fernando Rodriguez

Tasta aquí los españoles. Sólo de Miguel Fernández, en Maloya, se dice que es mestizo, pero no por ello se le excluye de la lista, lo cual es digno de ser tenido en cuenta, por cuanto puede hacernos sospechar otro tanto de parte de los restantes nombres.

En San Sebastián no hay minas, y en las demás partes son 
de la pobreza que sabemos. ¿De qué viven estos pobladores? En Mota, la pregunta se satisface de manera más detallada. Los ocho - diez españoles de Chianetla se dedican a contratar, rescatando pescado, ostra y camarón a los indios del lugar. De la misma contratación de pesca y saca y rescate de sal se mantenían los de la villa vecina. 4 Esto mismo nos confirma en la idea de ser éstas las más seguras fuentes de riqueza de la provincia. El propio obispo, hablando de Culiacán, explica que, descontando a los escasos encomenderos, "los demás vecinos son mercaderes, que traen ropa de Castilla, de China y de la tierra, vinos, aceites y lienzos de empleos que van a hacer a México y los venden allí en sus tiendas, que eran hasta cinco o seis. Otros vecinos viven del trato de las pesquerías, que como arriba queda dicho las hay muy gruesas en esta comarca, y de la grangería de la sal, que también hay mucha, que el un número y otro sacan en sus recuas en gran cantidad y los llevan y sacan para todo este reino y el de Nueva España y (Nueva) Vizcaya, que es el principal bastimento de todas las citndades para en los tiempos de Cuaresma, porque no es bastante el pescado iresco que cada día se toma en los ríos". 5

Por punto general asienta algo más tarde Arregui de los españoles de toda Nueva Galicia el ser de buena presencia, altos y gentiles, blancos y rubios, corteses, agudos, de buen natural. De expresión correcta, "que en las estancias y lugares más remotos se habla la lengua española tan cumplida y pomposamente como en la Corte o Toledo". Lo más interesante para nosotros es sn "agilidad" para todas las cosas de jineta, de labranza y de todos los oficios en aquel reino y en Nueva Vizcaya, precisamente por la falta de oficiales que obligaba a cada hombre a ser apto para todo lo necesario. "Y se hallarán pocos que no sepan herrar un caballo, hacer y componer una silla, sangrar y quitar una harba a navaja, cortar un vestido, deshacer una llave de arcabuz y volverla a componer, hacer un tornillo, templar unas pajuelas, refinar 
la pólvora, armar una casa, guisar una olla, aparejar y cargar una mula, domar y capar potros, novillos y machos y los demás aninnales caseros, hacer mal a un caballo, esperar un toro, hacer una petición y enmarañar un pleito, purgar y jaropear y curar un enfermo". 6

Arregui, en cambio, no arroja más luz sobre el número de españoles en las provinciás de la costa, y dice simplemente de $\mathrm{Cu}$ liacán que tenía "más de treinta vecinos españoles". 7

Los extranjeros de Sinaloa

Una afortunada casualidad nos permite llegar a conocer la extraordinaria afluencia de individuos europeos no españoles a las costas del Pacífico. Individuos a los que sin duda el clima y los alistamientos militares llevaban además, de preferencia, a la villa de Sinaloa, hallándose en cambio muy rara vez en los núcleos europeos de la tierra caliente. Una real cédula de $I{ }^{\circ}$ de mayo de I606 ordenó a Urdiñola formar y enviar a España relación de los extranjeros existentes en Nueva Vizcaya. El gobernador, ${ }^{8}$ parc. que nadie conociese su propósito, dispuso hacer minuta de todos los vecinos estantes y habitantes en el reino, y de ella extrajo las noticias relativas a los extranjeros, que por la referente a nuestras alcaldías eran:

En Mayola, Francisco López Viera, portugués, natural de Ceuta, que llevaba veintidós años residiendo en la gobernación. Baltasar de Fonseca, portugués también, de Braga, con catorce años de residencia allí.

En Copala y Panuco sólo se cita a Baltasar Fernández, asimismo portugués, de Oporto, que estaba en la gobernación desde ocho años atrás.

En la villa de Felipe y Santiago de Sinaloa se hallaron: Alejandro Genovés, natural de Génova, que servía hacía ocho años ya

6 Arregui, 38-39.

7 Arregui, 107.

8 Urdiñola a S, M., carta autógrafa. Parras, 2 abril 1607. Guadalajara, 28. 
como soldado. Gaspar Marraco, genovés, igualmente soldado, que estaba allí hacía seis años; Francisco Rodrígttez, portugués, natural de Oporto, único del que aquí se dice estar casado y al parecer también soldado con ocho años de servicio en el lugar. Finalmente, Jusepe Correa, de Génova, recién llegado, pues sólo contaba ocho meses de residencia en Sinaloa.

No sorprende la preponderancia de los portugueses, que en las décadas en que fueron vasallos del mismo rey que los castellanos gozaron de grandes facilidades para introducirse en la América española. De ellos los hubo ilustres en Nueva Vizcaya: seguramente el más destacado fue aquel capitán Alberto del Canto, natural de la isla Tercera, fundador de la villa del Saltillo. Torlavía en tiempos de Ibarra, son dignos de mención aquellos ocho soldados portugueses, mineros en San Martín, que atravesaron setenta leguas de serranía alta y fragosa en busca de metales, que finalmente hallaron en la vertiente al mar del Sur, a ocho leguas de la villa de San Sehastián: tal fue el origen del real de las Charcas, primer descubrimiento minero de Chiametla y causa principal para que la provincia no se despoblara. 9

Pero en las provincias de la costa el más interesante es aqquel ntro de que hace mención López de Vicuña alogín tiempo desputés: aquel Gaspar Alvarez "Curtimenta", marino, que poséa astrolabio, descubridor de placeres de perlas en las costas de Sinaloa, y que instaló fábrica de jabón, curtiduría y zapatería en la villa. que estaban en pleno rendimiento hacia I620.

Sin que necesitemos hablar de los jesuitas de todas las nacionalidades que concurrieron a la tarea de evangelizar a los indios sonorenses y sinaloenses, la presencia de estos extranjeros debía contribuir a dar a las pequeñas poblaciones st más acentuado carácter de frontera y crisol cultural.

9 Obregón, 106-107. 
LA VILLA DE LOS DOS APÓSTOLES

Como no podía menos de suceder tratándose de poblaciones españolas en las Indias, las poblaciones de Sinaloa tenían nombres de ángeles, de santos y de mártires: así ocurría con los pueblos y rancherías de los indios, con las misiones y los reales de minas, con las haciendas y los ranchos. Las tres villas se llamaban de San Sebastián, de San Miguel y de San Felipe y Santiago. De esta última hablaremos aquí para subsanar la escasez de noticias que hasta ahora hemos venido sufriendo.

De sus pobladores, algo se ha sabido en el apartado anterior. De su historia son bastante conocidas las sucesivas fundaciones hasta que adquirió visos de perdurabilidad con el asentamiento allí de una guarnición que en I 598 sumaba treinta y dos soldados. ${ }^{\text {10 }}$ Entre ellos debieron llegar algunos de los extranjeros ya conocidos.

Esta fuerza militar, que es lo único que se cita en las descripciones de Mota y Arregui, constituyó en verdad el tercer aluvión de los componentes del núcleo europeo.

El primero fue el dejado por Francisco de Ibarra. De ellos todavía pudo Urdiñola ${ }^{\text {II }}$ interrogar a Tomás de Soberanes y Antón Ruiz, que vino con su padre siendo mancebo. A continuación se incorporaron algunos otros, la mayoría traidos por Hernando de Bazán : Bartolomé Muñoz de Pro, Diego Rodríguez, Hernando Alvarez, Francisco de Llanes, Juan de Grijalva, Juan Pablo...

Estos son los españoles que se constituyeron en villa y nombraron sus alcaldes, y de los que Urdiñola comenta la miseria con que vivían, al tiempo que confía en las riquezas del país, y en las posibilidades indudables de fundar nuevas villas en los ríos que se presentaban aún más al norte: en el río de Sinaloa, la Vieja, en el Mayo, en el Yaqui... Pero indudablemente, si se quitase el presidio los escasos habitantes se verían obligados a abandonar

Io Don Diego de Velasco a S. M., Durango, 8 abril 1598. Guadalajara, 28.

II "Información hecha por el gobernador Urdiñola cerca del estado de la provincia de Sinaloa". 4 diciembre I603. Los que se citan en el texto figuran entre los diez testigos que declararon en dicha información. Los dos restantes fueron Pedro de Robles y Diego Martín. 
la tierra, pues no serían fuerza suficiente para resistir el menor morimiento de aquellos indios de carácter belicoso. Cuando a poco la guarnición se aumentó a cuarenta hombres y treinta de ellos se adelantaron a formar presidio unas leguas adelante, en Carapoa, la provincia ganó en seguridad al contar con esta cobertura más setentrional, y Sinaloa se convirtió en el lugar más próspero de la costa. Las minas que una y otra vez resurgían o se descubrían en la vecina Sierra Madre, aunque no pertenecían a la jurisdicción, daban vida a la villa impulsando a los vecinos a aconeter siembras o, más fácilmente, a acudir a rescatar granos de los indios que habían dado su obediencia al rey, y este comercio atrajo nuevos pobladores, de suerte que hacia I640 se calculaban a Sinaloa entre ochenta y cien vecinos. ${ }^{\mathbf{2}}$ Poco a poco se había ido acumulando el reducido potencial humano que, sin embargo, contribuiría a hacer factible la ocupación de Sonora, que definitivamente aseợuráa la clominación española de la costa del Golfo de Californias.

\section{Eil hundimento demográfico de CultacÁn}

A Lázaro de Arregui en i625 sólo le interesaban los tributarios de la provincia de Culiacán, que era de Nueva Galicia, y no el número de naturales cle las restantes alcaldías. De Culiacán al menos dice que había 530 indios tributarios de la nación pacaje, situada entre el río de Piaxtla y el de Culiacán; 350 de los tahutes, entre la villa y el mar; y 256 de los tebacas, que estaban arriba del río Humaya, más otros indios en cilra superior a 400 que no tributaban por ser nuevos, recién convertidos, serranos y apartados de la comunicación de los españoles. Así pues, Arregui nos da un total de I.I36 tributarios, y nos deja en la perplejiclad de cómo interpretar esta cifra y parangonarla con la cle Mota. Habiendo tributarios y medios tributarios entre los indios, resulta imposible conocer en qué proporción se combinan para componer

I 2 Pérez de Ribas, I, 263. Biblioteca Nacional de Madrid. Mss. 3010 y 3026. 
aquella entidad. Nos conformaremos así con advertir el incremento que indudablemente producen las conversiones.

En I67I, sin embargo, fecha a la que responden las únicas noticias que podemos comparar con éstas, el número de tributarios se ha reducido a 335 , y el motivo no ha de ser el de pase de pueblos a encomiendas de particulares, pues precisamente nos hallamos en época de signo contrario y está reciente la reincorporación de cinco pueblos a la corona. Entre el I 2 de julio y el 19 de noviembre de 167 i lleva a cabo el alcalde mayor Calderón la visita de los pueblos de la provincia y con ella la tasación de sus tributarios. Transcribimos a continuación los datos que se desprenden de estos autos, 13 advirtiendo tan sólo la irregularidad con que se suceden las fechas en ellos, fruto tal vez de haberse copiado desordenadamente una serie de autos redactados en hojas sueltas.

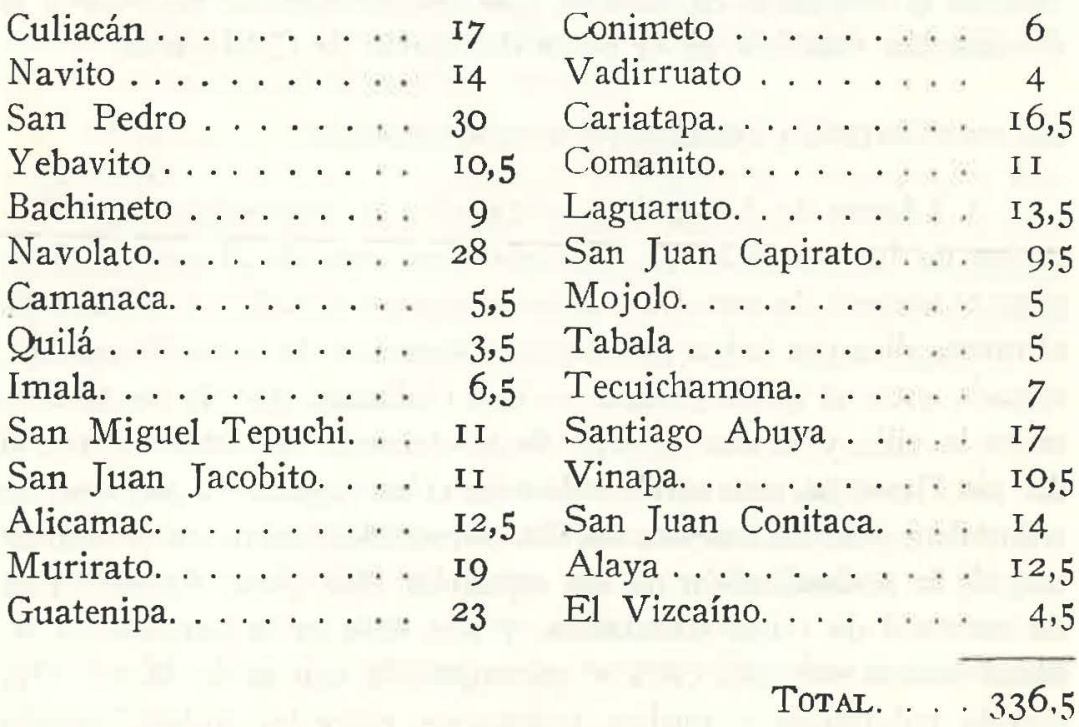

Aquí están los veintiocho pueblos, en el orden en que proba-

13 Folios 22v. y sigs. de los autos. Guadalajara, 15. 
blemente fueron visitados. De ellos, Alicamac, Murirato, Guatenipa, Cariatapa y Tabala entraban en la Corona el $x$." de cnero siquiente. Pero cómo comparar esta lista con la mucho más extensa de Mota? Sin duda que nuchos lugares citados por el obispo se habían abandonado tiempo atrás; anteriomente recogimos unas palabras en que el mismo alcalde mayor habla "del pueblo antiguo y despoblado llamado Atamura", y como éste había otros ignal. mente desaparecidos: pero aún así resulta difícil explicar la supresión de los cinco pucblos con que termina la relación de Mota y que suman ciento treinta vecinos, a no ser que supongamos que, hallándose próximos a la siera, se viesen mu afcctados por las sublevacion de stus moradores. Cabe también suponer que estos y otros pueblos permanecían aún en encomicnda cuando Calderón elaboraba su tasación de tributarios, pero de esto no nos gneda prueba documenta! conocida. En cambio si consicleramos abora d testimonio de Arregui, in más próximo cronológicanente a Mota que a Calderón, advertiremos que entre Arregui y el alcalde mayor, a través de turos cincuentá años de silencio, se perfila con la más dramática claridad el enorme descenso de la población india que va de los 1136 tributarios de 1625 a los 336,5 de 1671 . ;Un $75 \%$ de desnivel entre los dos extremos de la curva no es fácil de explicar, aun en el caso de que Calderón omitiese los pueblos en cabeza de particulares!

Arregui cita no menos de diecinueve núcleos de población entre Piaxtla y Culiacán, ausente de la lista de rór ; quince desaparecidos en el valle inferior del río de la villa; y diez en la región vecina a la sierra. Finalmente se persuade ser válicla para toda la provincia la disminución advertida del contraste de las cifras de Arregui con las de Calderón por el hecho de que entre los poblados extinguidos se hallan no pocos que figuran como corregimientos, es decir, pueblos de la Corona en relaciones de empleos provistos por la audiencia de Guadalajara, como lo eran Baila, Tacolimbo, Cocala, Ilarito, Chilobito y otros seis hacia

I4 Arresui, 005-106. 
I 575, ${ }^{15}$ y Baila y Cogote, por lo menos, en $1607,{ }^{16}$ algunos de ellos ya no figuran en Arregui, otros desaparecen después de redactada su obra. El decrecimiento rapidísimo de la población india en Culiacán es, de cualquier modo, indudable. Y no siendo, ni mucho menos, seguro el canon demográfico que significa un "tributario", nos abstenemos de aventurar una evaltuación global de los habitantes indígenas de Culiacán en estos momentos y que constituían los restos de aquella alta cultura con amplio soporte de población $\mathrm{y}$ formas económicas y artísticas en apreciable grado de evolución ${ }^{17}$ sobre la que se asentó la última conquista de Nuño de Guzmán. Y si importante erá este grupo en tiempos de la conquista, ¿que se dirá ahora de él, cuando toda Chiametla puede darse por desierta, octupada por sólo un centenar de vecinos?

\section{LA MULTIPLICACIÓN DE LA POBLACIÓN}

\section{INDIA POR LA EXPANSIÓN}

Pero es conveniente pasar ya al norte de Culiacán, a la alcaldía de Sinaloa, única que, sobre su constante riesgo, promete un futuro próspero y una expansión cierta. Si en Culiacán pueden contarse por centenares los tributarios, los habitantes indios de Sinaloa podían sumarse por decenas de millares, y stı incorporación a la vida económica y social de la provincia, aunque todavía no se había realizado hacia 1640 , se iba haciendo lentamente posible gracias a su pacificación y evangelización por los presidiales y los misioneros.

A principios de siglo, cuando Urdiñola dispone se reciba información sobre el particular en la villa de San Felipe y Santiago, ${ }^{18}$ se calculaba que hasta veintidós mil indios podían ser los

I5 "Alcaldías mayores y corregimientos y tenientazgos que se proveen en el Nuevo Reino de Galicia y las personas en quien están proveídos, son los siguientes" Guadalajara, 6.

I6 "Relación de los proveidos en oficios de justicia, partes y calidades de cada uno", con carta de la audiencia a S. M., Guadalajara, 19 abril I607. Guadalajara, 7 .

I7 Vid,, Kelly, Isabel : Excavations at Coliacán, Sinaloa. "Ibero-Americana", 25. Berteley, I945.

I8 "Información" de 1603 , preguntas $2 .^{\text {a }}$ a la $5 .^{\text {a }}$, Guadalajara, 28. 
que tenían contacto con los españoles, y de ellos, en unos treinta pueblos situados en general en radio de doce leguas de la villa, podían ser nueve mil los bautizados. I os demás - fuerteños, suaques, tehuecos, sinaloas y otros- permanecían gentiles. El hecho prodigioso era que en 1640 , por la acción conjunta de soldados y Pacles, se habian anexionado a Sinaloa más de ciento treinta leguas en profundiclad al norte, teniendo la provincia sesenta de anchura entre costa y sierra. ${ }^{\text {In }}$ Aquel espacio 10 ocrupaban unos ochenta mil a cien mil indios, dando esta última cifra en 1640 el P. Andrés Pérez de Ribas. ${ }^{20}$ Todas las estinaciones oscilan entre esas dos: en r6zs los Padres de México decían que los administrados en Sinaloa eran más de noventa mil, siendo los bautizados desde el principio en aquella provincia, entre párvulos y adultos unas doscientas nil almas. ${ }^{2 \pi}$

Los datos más detallados, con todo, son los de la "Razón y minuta de los indios que se administran en las provinciass de la Nueva Vizcaya", 22 y que fija la población india de Sina!oa, en la parte entonces reducida a misión, en estos términos, que aluden a los distintos jesuitas allí actuantes y sus neófitos:

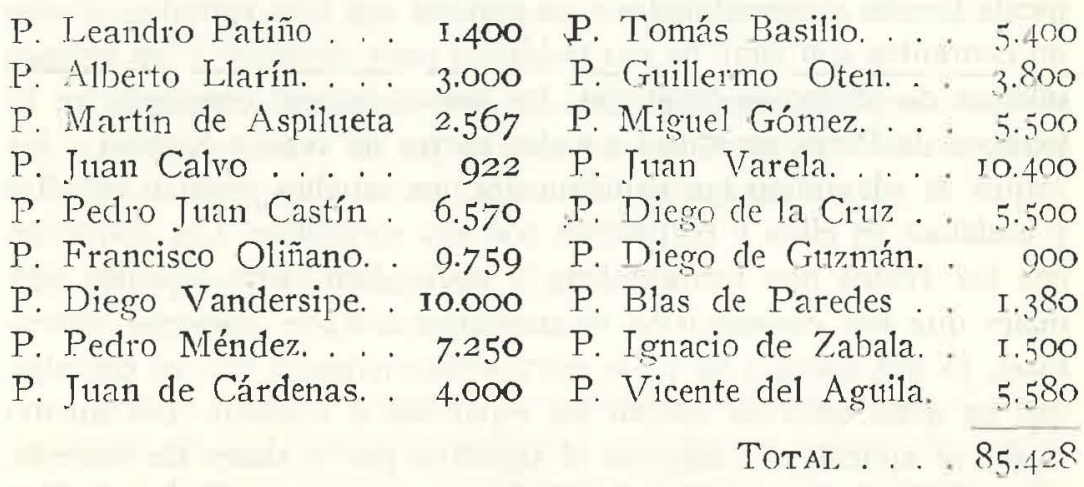

In Biblioteca Nacional de Madricl, M'ss. 3.026.

20 Carta de Pérez de Ribas inclusa en otra del obispo de Puchla de los A geles a S. M., Puebla, ro de septiembre 1640. Guadalajara, 9.

2 I Informe de la Compañia sobre Sinaloa. México, iz septiembre loj8. Citadalajara, 138 .

22 Bandelier, II, I 52 -I 53. 
Inútil ponderar el beneficio que para la provincia significaba la incorporación de tan nutrido contingente de nativos a sus cuadros económicos y defensivos, pobres en extremo cuando Urdiñola pasó la sierra para visitar la villa. Pero las predicaciones del gobernador llevaban cannino de realizarse.

Sin embargo, el propio Pérez de Ribas citado reconoce la disminución del número de indios en Sinaloa, repitiéndose en st1 obra las anotaciones de epidemias de viruelas y sarampión. En un momento determinado establece que las causas de la mortalidad de los naturales son los "cocoliztles" y los servicios que los españoles les exigían en labranzas, minas y otros trabajos, pero desde luego no precisamente por esto último, puesto cue en Sinaloa no había tales faenas y sin embargo Jos indios eran cada vez menos. ${ }^{23}$ Lo que a continuación asienta podría tal vez valer para Sinaloa, aunque no se diga explícitamente así. La disminución de los indios -dice el historiador jesuita- no ha sido tan grande conno parece; aunque hay muchos pueblos asolados, son muchísimos los indios que han acudido a los ranchos, haciendas y minas de los españoles, que antes no había; en estos lugares podían tener igualmente tierras y comodiclades y en general son bien tratados. Y aúm no contentos con salir de sus poblados para dirigirse a los vecinos núcleos de población españoles, los nayos habían emigrado ya en tiempos de Pérez de Ribas a todas partes de Nueva España y los yaquis se adaptaban tan rápidamente que muchos poseían caballos y andaban en ellos y trajinaban con stus carguillas. Los adquirían con los frutos que recolectaban, y codiciaban tanto aquellos animales que por conseguirlos se animaban a hacer mayores sementeras, lo que hacía a su valle extraordinariamente rico en cereales, que en años estériles venían los españoles a rescatar. Del mismo modo se aplicaban a cultivar el algodón, por el deseo de vestirse, y a trabajar la lana, contando con las ovejas que los Padres habían introducido.

El afán de bienes materiales, propio de una cultura ya un

23 Pérez de Ribas, II, 26. 
tanto avanzada como la que hallaron los espanoles de Culiacin al norte, en las zonas más habitables del país, hizo de estos indios eícáces colaboradores de los blancos y an instrumento jdóneo para el impulso de la economía del noroeste de México. "Por ganar un vestido, $y$ más por que sea algo galano, dejan su tierra y sus mujeres y salen a veces cincuenta y más leguas fuera de la provincia a buscarlo con su trabajo. Razón por que en parte también se la disminuido algo el gentio de yaquis, como de los mayos se escribió: y aunque algunos vuelven, otros se hacen a la vida entre españoles y quedan con ellos, o en reales de minas, donde los jornales del trábajo son más crecidos y los vestidos para eilos más galanos". 24

Ni que decir tiene que hasta tanto que empezó a desarrollarse la minería en Sonora, los indios del país acudían a los reales de la Sierra Madre, y aún más al interior, atraiclos por el brillo de Farral, Minas Nuevas y El Oro. Los libros de cuentas indican que hacia $165^{\circ}$ todos los asalariados de Minas Nuevas procedían de Sinaloa y Sonora (ópatas), y desempeñaban precisamente los oficios que requerian más destreza: fundidores, barreteros, tenateros, y ellos y los mexicanos formaban el barrio indio de Parral. ${ }^{25}$

La primera expansión de Sinaloa, que dio como resultado la efectiva dominación de los cuatro ríos -.Petatlán, Fuerte, Mayo y Yaqui- no poclía haber sido más provechosa.

I LOS GRUPOS INDIOS ERRANTES: TEPUSTLA, Achires y Uparo o Seris

Siendo escasa y dispersa la población española sobre el vasto territorio de las provincias costeras, por fuerza habian de quedar grupos inclígenas, auncue ciertamente reduciclos por su misma condición, al margen del control y de la autoridad de las autoridades civiles y de los misioneros. Estos núcleos indios son, por supuesto,

24 Pérez de Ribas, II, 127.

25 West, 49 y 55 . 
nómadas del tipo de los cazadores y recolectores, en los primeros estadios de la evolución cultural, y su misma presencia allí es uno de los rasgos típicos de las fronteras españolas en el continente americano, por constituir ellos justamente un freno, un obstáculo a superar, un problema tanto político como cultural para el desarrollo normal de la expansión. El fenómeno en general es extensivo a todas las Indias - ¿ no son todas las Indias más o menos densamente pobladas, una inmensa frontera en todos los sentidos?- punteadas todas ellas de zonas, de rincones olvidados, de extensas regiones a veces, que se escapan al entramado de la malla administrativa del İmperio y a la zona de influencia de los rúcleos civilizadores, enlazados en muchas ocasiones por rutas cuyas distancias no se miden por leguas, sino por riesgos corridos, dificultades naturales vencidas, penalidades inacacables sufridas.

En lo que dentro de las mismas Indias consideramos ya propiamente frontera - frontera de guerra, si se quiere- los accidentes geográficos, la condición del territorio, la distribución de los grupos indigenas y la de los propios españoles juegan de tal suerte que producen unas claras yuxtaposiciones de los reductos de tribus insumisas junto a las dilatadas avanzadas de los adelantados de la penetración española, que van afincando sus reales a lo largo de los prolongadísimos caminos de la tierra adentro, a distancias inverosímiles de los centros neurálgicos del poder político, de la fuerza y de la riqueza. Por lo mismo, estos mismos centros pueden quedar relativamente cerca de los más próximos refugios de los grupos aún no civilizados, y esto es concretamente cierto para el caso de México, Guradalajara y Zacatecas, respecto de la frontera setentrional de Nueva España.

Así no es de extrañar que los colonos hayan penetrado profundamente de Guadalajara al norte, en busca de las minas, dejando a sus espaldas la rochela del Nayarit, las naciones caníbales de la serranía - ¿qué otra razón de ser tienen el pequeño presidio de San Sebastián, y el vecino de Acaponeta en Nueva Galicia?-los grupos vagantes junto a la costa en el Piaxtla y en el Humaya 
la árida tierra de los seris. Los grtpos humanos que se mueven aqui coiservan su independencia gracias a la pobreza e inhospitalidad de su territorio, en breñas inacesibles o en las marismas mas cenagosas y desérticas; alli estarán hasta que el misionero vaya a buscar sus almas, o hasta que sus correrias y depredaciones muevan a los españoles a declararles guerra abierta, si no es que antes su contacto con los núcleos de población les ha ido atrayendo por razón de los atractivos dei comarcio o de la ganancia que pueden obtener thediante su trabajo personal.

En la sierra que corre al oriente de Acaponeta y San Sebastián, los coras y tepahnunanes mantendrán su libertad hasta entrado el siglo XVIII. El Rincón de Zamora, al margen del camino de Durango, donde los españoles entraron con motivo de la sublevación tepehuana de r6I6, era tmo de los espantosos abismos abiertos en medio de la cordillera, y en todá la zona habitaban los que Arregui llama indios serranos, ${ }^{26}$ esto es, que ro viven en pueblos, a estilo sedentario. ¿Pero no iban estos inclios, movidos por el interés, a tomar parte en fas faenas de la cosecha de sal cle Chiametla? Mota, que supo de ellos veinte años antes, llana a algunos de ellos nación de Tepustla, que tenía sus rancherías en la zona de Mialoya, Copala y Pantico, y corría la tierra en busca del sustento que le proporcionaban la caza y la pesca, vagando por el despoblado de veinticuatro leguas que nediaba entre el real de Panuco y el pueblo de Elota. ${ }^{27}$

Algo más al norte señala el obispo la presencia de otra nación de indios vagantes. Un cuarto de legrta más abajo de lá villa de Culiacán, se une al Tamazula el río de Humaya, y de la junta se forma un poderoso brazo de agua que va a meterse en el mar catorce leguas adelante, en la llamada provincia de los Achires. La tierra de los achires tenía su principio en el pueblo de Guachimeto: de aquí al nuar había diez leguas de despoblado, "y en ella anda una mación de indios desnudos que llaman achires, que ni

26 Arregui, 103.

2), Motal, $9 \mathrm{r}$. 
tienen población, ni siembran, ni cogen, porque toda su ocupación y contratación es en la pesca del mar que hacen en el puerto de Guayabal". ${ }^{28}$ De los achires no volvemos a saber hasta 1672 fecha en la que, tras haber estado reducidos a pueblo en alguna de las misiones jesuíticas de la vecina provincia de Sinaloa, se habian vuelto a sus marismas y pesquerías. ${ }^{29}$

Los tepustla y los achires son los más meridionales ejemplares de los grupos indios nómadas de las costas del Golfo. La más importante y conocida representación de ellos la hallamos más al norte, y Obregón, el cronista de Ibarra, nos da una referencia que se anticipa bastantes años al XVII. "Los de Uparo, que están en la costa, son salvajes, no siembran, comen el grano de bledos, caza y pescado, y todo género de sabandijas silvestres, y aunque todos gentes idólatra y malvada, no comen carne humana". 30 Notable diferencia esta última respecto de los serranos de Chiametla, los bárbaros de Cacalotlán que entre la expedición de Guzmán y la de Ibarra habian diezmado la población de la provincia, y se contaban por millares los cráneos humanos que tenían conservados. $3 x$

Estos Uparo, habitantes entre el valle de Sonora y el mar, de los que los sonoras se defendian y con los que guerreaban para conseguir sal, son sin duda los seris, de larga y dolorosa historia para la provincia desde el último tercio del XVII y en todo el siguiente siglo XVIII. En la centuria objeto de nuestro estudio su presencia se advierte mucho menos que en fechas posteriores, $y$ es difícil seguir el rastro a la nación a través de las escasas noticias documentales que nos llegan.

La primera noticia la debemos al fiscal de la audiencia de Guadalajara, don Fernando de Haro y Monterroso, que el 26 de diciembre de 167 I hace abrir expediente contra unos españoles que se hallaban de paso en la ciudad trayendo consigo varios indiós

28 M'ota, Ior y 106.

29 Patronato, 232, ramo I, fols. I-6 y 20.

30 Obregón, I 48 .

3 r Obregón' ro6-roz. 
que se supone sean escliwos. Los autos que sigten no son muy extensos, pero arrojan luz sobre puntos en verdad importantes, como el que interesa aquí. De los diez niños tráclos de Sinaloa y que el fiscal hizo llevar a su casa, donde los atendió cono mejor supo, tres eran seris. Nicolás Ranos, uno de los españoles con quienes Haro se querelló criminalmente en esta ocasión, declaró que los dos indiezuelos que él llevaba le habian sido dados por el cabo del presidio de Sinaloa, Andrés de Brielna.

Al parecer, hacia 1670 los seris calisaban bastantes daños en las misiones vecinas; la fecha tiene su importancia, porque varios testimonios coinciden en señalar que en 1669 y 1670 se produjo una aguda sequía y esterilidad en Sonora. 32 Los seris, pues, acudian a practicar rapiñas en los poblados del contorno. Con tal motivo entró Buelna desde Sinaloa con quince presidiales y un número indeterminado de vecinos amados y en la primera campaña o mariscada, el iz de junio de róp I, logró dartes an "abazo", término ya algo anticuado en esta época con que los espańoles designaban el ataque dado por sorpresa a la incierta luz del alba. La maniobra del cabo tuvo el éxito que revelan las cifras, pues hizo sesenta muertos y veinte prisioneros a los seris. De estos uitimos se repartieron cuatro a los españoles que habían intervenido en la campaña. Buelna por seguncla vez entró a recomer la tierra de los alzados y apóstatas seris - la denominación apóstata sugiere que anteriormente habían sido bautizados y adoctrinados en misión-, y la víspera de San Ignacio siguiente, 30 de julio de $167 \mathrm{I}$, dio albazo a una ranchería de setenta 11 ochenta seris a orillas del río Bacuachi. Los seris tuvieron cuarenta muertos y

32 Juan de Mendoza, declarando ante el fiscal Blanco, dice: "En los años pasados, porque llegó a valer una fanega de maiz ouce y cloce pesos, solian iract los indios a sus hijos a las dichas provincias de Sinaloa y Sonora y darles a los españoles para que los alimentasen, y si to los querian recibir se iban y los dejaban, con lo cual los hombres caritativos los cogian y llevaban a sus casas y les cuidaban por amor de Dios". Fin "Testimonio de los autos hechos a pedimento del St. físcal de la audiencia de Nueva Galicia sohre la aprehensión de los indiezuelos que se traían de la provincia de Sonorn", I672. 25 fols. Guadalajara, J 2. Otras noticias sobre tales hechos, en informe de Dicastillo. Patronato, 232; rano $10^{\circ}$, fols. 46-127, cuyas palabras recogemos en otro capítulo. 
veintitrés cautivos, pero en la acción murieron el cabo y cuatro auxiliares, y por la noche fue atacada la caballada de los espanoles: destacóse Ramos en la lucha y por eso le dieron un nuchacho, de dos que se repartieron a los vecinos, y era éste hijo del jere seri Siona. 33

Don Gregorio López de Dicastillo y Aramburt, alcalde mayor de Sonora, nos permite conocer algo más de las incidencias de las hostilidades en uno de sus alegatos contra el régimen establecito por los jesuitas. "El Padre Cornelio Gillert, misionero de Cucurpe - escribe refiriéndose a I673- fue cansa de que se comenzaran a alborotar los indios seris gentiles confinantes a su misión, que era una de las de esta provincia de Sonora, y porque los dichos indios con hambre abriendo una vez la despensa de dicho Padre sacaron unos tasajos de ella y un poco de maíz para socorrer su necesidad, y entonces sólo por esto el dicho Padre misionero hizo armar a la gente del servicio de la casa de su misión y a los indios de ella, y enviando por cabo de todos a un mestizo que le servía llamado Lázaro de Acuña, hizo el dicho Padre de sola su autoridad a la dicha gente hacer entrada de guerra contra los dichos indios seris gentiles y su caudillo Siona, yéndolos a buscar y a inquietar dentro de su tierra, y habiendo muerto algunos de ellos la gente del dicho Padre Cornelio, sobrevino después sobre ella el dicho Siona y sus gentiles y mataron más de treinta indios cristianos de la misión dicha, y entonces el dicho Padre misionero avisó por una carta de lo que pasaba al alcalde mayor de Sonora, que lo era entonces el capitán don Pedro Alvarez Castrillón, pidiéndole con instancia acudiese con gente española a reprimir los indios gentiles, y se comenzó a alborotar la tierra y a tener miedo grande los Padres misioneros y obligaron al dicho alcalde mayor a hacer gente y a salir contra los dichos indios gentiles, como todo lo dicho es público y notorio, y que habiéndole sucedido en el cargo de tal alcalde mayor don Gregoriu López de Dicastillo - es el mismo cuyo escrito vamos siguiendo-

33 Declaración de Nicolás Ramos, en "Testimonio" citado. Guadalajara, 12. 
por instancias grandes que ef dicho Padre Cornelio hizo al capitán José Romo que lo era por aquella parte de esta jurisdicción, le dio avisos al nuevo alcalde mayor de la inquietud de los dichos seris pata que enviase gente de socorro para reprimirles, como la envió, para lo cual hizo primero junta en el real de San Juan de Sonora, haciendo con acterdo de ella el dicho socorro y con orden que no entraran los soldados en la tierra de los gentiles, sino que hiciesen guerra defensiva". No satisfechos con esto, los Padres repitieron sus demundas hasta que vino a pacificar la tierra el capitán de Sinaloa, Otemín. 34

Ya tenemos a los seris enenistados con los españoles. Los largos textos, que hemos resumido o transcrito por contribuir de alguna manera al conocimiento de la historia de este desgraciado ptreblo, son las primeras noticias que ven la luz referentes a fecha tan temprana. Para entonces, Sonora tiene sólo tres décadas de vida, y queda por delante un cuarto del siglo XVII en que volverán a darse contactos, bélicos 0 amistosos, y en que los españoles aprenderán a distinguir diversas ramas dentro de la nación seri.

\section{Los ESPAÑOLES EN SONORA}

Gracias a la riqueza minera - aparatosa pero superficialde Sonora, arraigó la población española definitivamente en las provincias de la costa, pues la bonanza de las minas y placeres del norte daba cterpo al tráfico mercantil de todas las localidades meridionales, y atraía además a mayor número de españoles que actudía a las comarcas vecinas. Gracias a esto últimn debió atumentar de manera notable la población blanca en esta provincia en los sesenta años del siglo, y ello es hasta cierto punto perceptible a través de algunos testimonios documentales.

En los momentos iniciales, cuando Sonora todavía solamente. ofrecía tierras, Perea hubo de acudir a Nuevo México sólo para traer como pobladores doce hombres, cle los que ocho de la fa-

34 Informe de Dicastillo. Patronato, 232; ran1o $10^{\circ}$, fols. 46-127. 
milia de los Pérez Granillo - "padres y tíos de mi consorte", dice Mange- descendientes de los compañeros de Oñate. 35 Rasgo este de la historia de Sonora extrañamente olvidado, porque. ¿quién imagina al abandonado Nuevo México convertido en matriz pobladora de otras provincias? Piénsase esto de Tlaxcala. de Zacatecas-y con cuánta razón-, pero no de Santa Fe. Y sin embargo, entre los factores que hacen posible la creación y consolidación de Sonora están junto a la expansión misional de Sinaloa y el paralelo crecimiento de Nueva Vizcaya, la actividad de los misioneros franciscanos de Guadalupe de E1 Paso y la estrecha vinculación de los sonorenses a los vecinos de Nuevo México, antes y sobre todo después de la sublevación de I68o. El hecho de la aportación de esta provincia al poblamiento de Sonora es bien comprensible si se recterda que Nuevo México contaba en vísperas del alzamiento de los "pueblo" unos tres mil españoles, cifra que estaba muy lejos de sumar las alcaldías costeras; aquella era una región muy poblada en comparación con éstas; y alli se dirigió el andalız Perea a buscar gente para cubrir las plazas de soldados que se hahía comprometido a mantener en su jurisdicción; y es muty significativo que para tener veinticinco soldados hubiese de traer doce de la gobernación del río Grande. En verdad que no debía haber muchos españoles en aquel entonces en Sinaloa y sus aledaños.

Los datos posteriores que podemos manejar para llegar a una estimación del crecimiento de esta población corresponden al año 1684 y son de índole poco propicia, porque consisten en un recuento $\mathrm{y}$ alistamiento de todos los hombres en edad militar hecho con ocasión de la alarma que vivió la provincia por aquellos días, cuando a las puertas de Sonora se precipitaban todas las naciones coligadas desde el Gila a la Sierra Madre y se temía una subversión repentina de todos los pueblos indios sometidos. El bando promulgado por Cuervo Valdés el I3 de mayo dio

35 Mange, Mateo: Luz de lierra incógnita en la América Setculrional y Diu. rio de las exploraciones de Sollora. México, 1926, 340-34I. 
lugar a una serie de "muestras" que arrojaron los siguientes clatos sobre el número de hombres armados y su distribución. ${ }^{6}$

Real de San Juan Bautista . . . . . 36

Valle de Teuricachi . . . . . . . . I2

Valle de Santa Ana Tepachi. . . . . 29

Nacatobori . . . . . . . . . . II

Bacanuchi . . . . . . . . 62

Real de San Miguel. . . . . . . 36

I86

A falta de un índice adecuado y comprobado para hallar sobre esta base el número total de miembros de las familias españolas de Sonora, nos limitaremos a apuntar que, si es válido el canon propuesto por Cavaignac para España, de 7 individuos por cada hombre en estado de portar armas, tendríamos I 302 pobladores. Con esta población - de ser cierta la hipótesis-y con acuuella fuerza se construyó y sostuvo en el XVIII la frustrada Nueva Andalucía, que al fin quedó con el más breve y no menos sugestivo nombre de Sonora.

Nada, en cambio, podemos decir de los pobladores de los reales de Ostimuri.

\section{OPATERÍA Y PIMERÍA}

La Sonora histórica ofrece el extraordinario interés de haber sido la última etapa de la expansión del dominio español y de evangelización sobre los pueblos de cultivadores sedentarios. Pimas y ópatas fueron los últimos núcleos asimilados dentro del marco de las instituciones políticas y misionales del Imperio, y esto - para la porción occidental de Sonora- en fecha tan temprana como 1650 , en que los jesuitas, tras una fugaz aparición

36 Escribanía 400 C, pieza 2, fols. 93-95V., I 08, I I4-I I6, I42- 43. 
de los franciscanos debida a don Pedro de Perea, habían establecido sus doctrinas en los cuatro ríos de Bavispe, Moctezuma, Sonora y San Miguel. Treinta años más tarde, cuando está naciendo la vida minera de la región y van a producirse las convulsiones de las fronteras vecinas, he aqui el censo de los pueblos. 37

Oposura. . . . . . . 334 Teuricachi. ....... 224

Cumpas. ......... 887 Tebidegt1achi. ...... 2I 4

Guaravas ........ 632 Cuchuta. . . . . . . 227

Oputo.......... 424 Arizpe ........ 4 I6

Nacori. . . . . . . 450 Chinapa. . . . . . . 393

Bacadeguachi. ...... 370 Bacuachi ........ I95

Sareba. . . . . . . . 262 Huepaca... . . . . . 268

Baseraca ....... 399 Sinoquipa. . . . . . . 367

Guachinera. ....... 538 :Banamichi ...... 338

Bavispe. . . . . . . 402 Aconchi. . . . . . . 530

Cuquiarachi ....... 380 Babiacora...... 445

Total de ópatas . . 8695

Matape... . . . . 482 Tepachi. ........ 388

Nacori . . . . . . . . 394 Cucurpe. . . . . . . . . 329

Rebeico. ........ 330 Toape. . . . . . . . 240

Batuco ... . . . . . 428 Opodepe. . . . . . . 320

San Javier. . . . . . . 480 Ures . . . . . . . . . 904

Necameri. ....... 362

Total de pimas bajos. . 4657

La relación no es ni mucho menos completa para la alcaldía de Sonora, puesto que faltan de esta relación los pimas nebomes, del curso medio del Yaqui, cuya cifra va incluida en la de las Zapata.

37 Datos que proporciona Decorme, II, 360 y 372 , sobre el cómputo de 
misiones de Sinaloa, aunque administrativamente correspondieran parte a Sonora y parte a Ostimuri. $Y$ aún queda por agregar a la población general de las provincias el núcleo de indios serranos, mezcla de pimas, ópatas, jovas y tarahtmaras, que octpaban el corazón de Ostimuri y no fueron convertidos hasta el ultimo cuarto de siglo. Unos y otros daban estas cifras en I678. 38

Tecoripa........ 269 Sahuaripa........ 682

Suaqui.......... 450 Teopari. ........ 369

Comuripa........ 450 Onapa......... 890

Onavas......... 875 Arivechi....... 466

Tonichi........ 5 IO Malzura......... 596

Movas. ........ 308 Yécora ......... 500

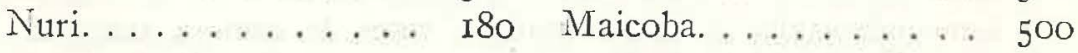

Total de nebomes . . 3007

Total de serranos. . 4003

Podemos a simple vista formular la hipótesis de que el rincón serrano de Ostimuri tiene ma población tan proporcionalmente crecida debido a su tan tardío contacto con los españoles, nientras que los pueblos del Yacui y de Sonora eviclencian un ya prolongado roce con el grupo dominante, roce que da lugar a una reducción selectiva de la masa indigena.

Los ópatas son la clave, la pieza básica de Sonora, por su, número y su fuerza, y por la difícil posición que ocupan, guardando el acceso a la sierra y al interior de la provincia a los pueblos nómadas situados más al norte. El XVII será en ellos un momento decisivo, al cabo del cual se habrá ganado para España este bastión del norte: la sumisión y fidelidad de los ópatas, que se harán proverbiales en la centuria siguiente, se acuñan ahora, con ocasión precisamente de la gran rebelión de los pueblos periféricos de la frontera setentrional de México. Y los ópatas habrán ganado para sí el haberse sumado a la causa de la civilización occi-

38 Decorme, II, 352 y 35.5. 
dental a la cual acabarán incorporándose con voz propia y precisá, como corresponde a un pueblo que ha sabido elegir su destino en un momento crucial, preñado de graves responsabilidades.

Los pimas, en cambio, son tal vez los conchos de Sonora: um contingente humano dispuesto en semicírculo en torno al más fuerte núcleo ópata y mostrando claras afinidades con sus vecinos del exterior, con los seris, los pápagos y los sumas, con los propios apaches tal vez. Su presencia se va diluyendo gradualmente en el espacio geográfico, hasta hacerse inasequible. Sus ramificaciones al noroeste - los sobaipuris o pimas del Soba- son alcanzadas a fines del XVII, pero su real anexión es verdaderamente problemática, pues los últimos acabarán desapareciendo casi en la lucha entablada con los nómadas, mientras que los primeros mantendrán una semi-independencia manifestada a veces de manera sangrienta. A través de las tierras de unos y otros se asomarán los españoles, durante tres siglos, al Gila, ocasionalmente -en ocasiones a veces señaladas, pero siempre como de paso-, porque e! Gila y los países que se extendían más allá carecieron de atractivo a los ojos de los pobladores de un Imperio que había llegado, en Sonora, a uno de los puntos que marcaban la máxima dilatación natural de las poderosas fuerzas desencadenadas en I 492. 


\section{Capítulo III}

\section{LA ADMINISTRACION DE LAS PROVINCIAS}

\section{LAS ALCALDÍAS MAYORES}

La unidad administrativa al occidente de la Sierra Madre es la alcaldía mayor; independientemente de que ésta entre en la demarcación de Nueva Vizcaya o Nueva Galicia. El alcalde mayor -o corregidor, en su caso- es por tanto la figura clave de la vida de cada una de estas pequeñas entidades políticas, que llamamos provincias menores, o simplemente provincias.

Es bien sabido que la provincia de Culiacán dependia de la gobernación de Nueva Galicia, con capital en la ciudad de Guadalajara. La provincia existía desde que Nuño de Guzmón fundó la villa de San Miguel, y sus límites no quedaron, naturalmente, determinados hasta que no surgieron las entidades colindantes de Sinaloa y Chiametla al norte y sur, y de Topia, en la sierra, más de treinta años después. Los límites setentrional y meridional de Culiacán se fijaron allí donde terminaban los pueblos dominados y asignados en encomienda a los vecinos de la villa, en los ríos Mocorito, al norte, y Piaxtla, al sur. No había límite al interior, ni hacía falta, porque un extenso despoblado mediaba entre Guzmanillo - víltimo pueblo de Culiacán- y Topia.

Las restantes provincias costeras eran parte de la gobernación de Nueva Vizcaya, con sede en Durango - y eventualmente en Parral. Su número varió con frecuencia a lo largo del siglo y no es fácil de establecer para un momento dado. El origen de la confusión está en el territorio de Chiametla, donde las alcaldías son creadas y desaparecen o cambian de nombre con extraordinaria 
movilidad, siendo así que además es ésta la región peor documentada.

Chiametla o San Sebastián fue originalmente el nombre de la única alcaldía que cubría todo el país, desde el río de las Cañas hasta el confín con Culiacán. Sin embargo, tal territorio debió fragmentarse pronto, tan pronto como aparecieron los diversos reales de minas que prosperaban a fines del siglo XVI.

La alcaldía del real de Panuco y Charcas remía estos dos centros mineros de la sierra. Su existencia nos viene mostrada por Urdiñola, que ordena en 1604 al justicia mayor redactar la lista de los pobladores.

La alcaldía de las minas de Cacalotlán y Maloya tenía el mismo fin de atender al gobierno de las pequeñas poblaciones surgidas al brillo de cualquier yacimiento argentífero, donde se congregaban gentes de todas razas y castas, vagabundos y buscadores. Esta provincia se llama también, indistintamente, de Copala y Mataroy, o simplemente de Copala, y mediado ya el siglo, I esta alcaldía fue anexionada a la de San Sebastián.

Piaxtla debía tener también por estas fechas un alcalde mayor, y 10 mismo Mazatlán, aunque sólo nos ha llegado un rastro de su existencia en el informe de Urdiñola sobre las salinas de Nueva Vizcaya. Si no figuran después en las listas de pobladores, ello se debe a que estas alcaldías servían sólo para mantener en obediencia a los núcleos indios y de mulatos residentes en las proximidades de la costa. Pero muy poco después los indios debieron extinguirse y los mulatos sabemos que disminuyeron extraordinariamente en número, apareciendo con posterioridad su pueblo de Mazatlán formando parte de la alcaldía de San Sebastián y Copala. ¿Se llegó tal vez a una mayor fragmentación del territorio? Es presumible, por cuanto la relación de los oficios de justicia - alcalde mayor que proveía el gobernador de Nueva Vizcaya

I Así consta en auto del alcalde mayor don Alfonso Pita de la Torre, en I667. Escribanía $396 \mathrm{~B}$, cuaderno $5 .^{\circ}$ de la residencia de Oca Sarmiento, fols. $80-83 v$. 
hacia I630 cita, ${ }^{2}$ entre utros del interior, éstos, correspondientes a la costa:
Piaxtla y Mazatlán
Chiametla y Salinas
Panuco y San Bartolonné
Minas de Maloya
Villa de San Sebastián

La unificación de Piaxtla y Mazatlán no es extraña, supuesta la despoblación de este lugar de que nos intorma Arregui. En cuanto a la separación de Chiametla y San Sebastián, no nos atreveríamos a asegurarla por la sola base del documento que citamos, porque la duplicidad de nombres de estas alcaldías podia, entonces como ahora, inducir fácilmente a error. Sin embargo, tres décadas más tarde, la alcaldía de San Sebastián se había fusionado con la de Copala y comprendía además el puebio de Mazdtín, pero había surgido provincia distinta, en el rico mineral de Rosario, que servía de capital y le daba nombre. ${ }^{3}$

En este momento, la aplicación del término Chiametla se hace sumamente confuso. El título de Pita de la Torre lo hace "alcalcle mayor y capitán a guterra del real y minas de Copala y su jurisdicción... agregándole... las provincias de San Sebastián, Chiametla, Maloya y la provincia de Piaxtla”. Este título es de 4 de enero de 1666 . $Y$ un mes después, en cambio, en 8 de iebreru de 1666 , se nombra a Juan de Uriquibel alcalde mayor del real dei Rosario, su partido y la provincia de Chiametla. 4 De todos modos, como puede verse, estos dos títulos dados por Oca Sarmiento comprendian todo el territorio de la antigua Chiametla. En I67 I se aseguraba que el gobernador de Nueva Vizcaya sólo nombraba dos alcaldes mayores al sur de Culiacán y éstos eran precisamente los del Rosario y Copala, yendo minidas a esta última Chiametla

2 Biblioteca Nacional de Madrid, Mss. 3.048.

3 Auto de Juan Uriquibel en Rosario, jurisdicción de Chiametla, 3 I de enero de 1607 . Escribanía $396 \mathrm{~B}$, pieza $5 .^{\mathrm{n}}$, fols. 77-79v.

4 Los dos títulos, en Escribanía 397 A, pieza I. a, fols, 3-9 y r5v.-I6. 
y la Villa de San Sebastián. 5 Esto es lo mismo que confirmó el gobernador García de Salcedo al año siguiente. ${ }^{6}$ Pero más adelante, en I682, con motivo de la publicación del juicio de residencia de don Bartolomé de Estrada, volvemos a hallar que Chiametla está unida al real del Rosario, formando provincia distinta de Copala y San Sebastián 7 - llamándose también a esta última provincia de Maloya. ${ }^{8}$ Estas son las dos mismas alcaldías que subsisten al finalizar el siglo, sin que nunca hayamos visto indicada su divisoria. La alcaldía mayor de Mazatlán, cuya existencia consta en I704, con este pueblo como cabecera, parece era la misma antigua de Maloya. ${ }^{9}$

Sinaloa es, no hay que recordarlo, la primera alcaldía de Nueva Vizcaya en la costa, y concretamente al norte de Culiacán ; su límite meridional está así bien definido, en el río Mocorito. La expansión hacia el norte bajo los auspicios de Urdiñola irá ensanchando su jurisdicción hasta que su segundo alcalde del siglo XVII, don Pedro de Perea, establezca la alcaldía de Sonora. Sonora, al norte del río Yaqui, será la última de las provincias costeras en constante crecimiento hasta el XVIII, ocupando las tierras mejores y más templadas.

Ostimuri, finalmente, es la alcaldía mayor creada por el gobernador Oca Sarmiento el I5 de octubre de I 668 sobre los reales de Los Gentiles, San Ignacio y San Marcos. ${ }^{\text {ro }}$ Su jurisdicción, entre el Mayo y el Yaqui, es la misma que en principio tuvo el teniente que el alcalde mayor de Sonora puso en estos minerales.

Las tres provincias setentrionales no sufrieron modificacio-

5 Certificación dada por el escribano Galarreta y que acompaña a la carta de Haro Monterroso a S. M. Guadalajara, ig marzo I67I. Guadalajara, II.

6 García de Salcedo a Don Francisco Fernández de Madrigal. Durango, 6 abril 1672. Guadalajara, 29.

7 Autos de la residencia de Bartolomé de Estrada, cuaderno r. ${ }^{\circ}$, fols. 39-50. Escribanía 389 A, pieza 2 .

8 Así se desprende de la solicitud de don Blas García de Dicastillo y Azcona, I686. Guadalajara, 4.

9 Residencia de Larrea, cuaderno $\mathrm{r}^{\circ}$, fol. 290 r. v. Escribanía 39 I A. I $21-122$.

ro Escribanía $397 \mathrm{~A}$, cuaderno $2 \mathrm{I}$ de la residencia de Oca Sarmiento, fols. 
nes después de esta fecha, salvo que alguna vez las dos últinas se proveyeron en una misma persona -así en el general don Carlos Gago de Mendoza, qute además obtuvo la alcalclía vecina de Casas Grandes-; y es también de advertir que Sonora, hacia el norte, tuvo su frontera en constante movimiento expansivo hasta fin de siglo, logrando así una clesmesurada extensión, aparte la segregación de Ostimuri.

\section{VINCULACIÓN DE LAS PROVINCIAS}

\section{A LAS AUTORIDADES SUPERIORES}

Para todo asunto dependen los alcaldes mayores, respectivamente, de Nueva Vizcaya o Nueva Galicia. La sólo relativa autonomía en cada campo del gobernador y del presidente-gobernador hace que en última instancia el gobierno de las pequeñas provincias quede en manos del virrey, annque esto se advierte pocas veces.

En el plano ideal, para asuntos de gobierno, los alcaldes mayores están subordinados, en casa caso, a las autoridades de Gutadalajara Q Durango. De hecho, la audiencia emite reales provisiones en materia de gobierno con vigencia en las alcaldias de Nueva Vizcaya. Pero aún más, Nueva Galicia aparece como entidad predominante por cuanto, en principio, toda Nueva Vizcaya está comprendida en el ámbito de su jurisdicción, en puntos de justicia, y es tribunal de apelación de los fallos de los alcaldes mayores tanto de Culiacán como de las restantes alcaldias costeras. Ya se verá hasta qué punto esto se realiza.

En materias de hacienda, que no son ciertamente muy importantes aquí, se observa la misma dualidad que en las de gobiemo: las alcaldías reconocen las Cajas Reales de sus respectivas gohernaciones, con sede en las mismas capitales de éstas. Los alcaldes mayores son los agentes de los ramos comunes de real hacienda. Luego hay sin duda ramos especiales, como es el de bienes de difuntos, que en todo el distrito de la audiencia están 
encomendados al oidor encargado del Juzgado de estos abintestatos o fondos legados a personas residentes en España. En último término, por supuesto, el virrey es el único superintendente o jefe superior de toda la administración hacendística del virreinato, y esta realidad se hace patente en los momentos críticos de peligro, cuando hace falta aprontar caudales en Guadalajara o Parral para atender a la defensa de las alcaldías. La sublevación tarahumara de 1697 da ligar al hecho no frecuente de delegar el virrey todas las atribuciones de la superintendencia en el presidente-gobernador de Nueva Galicia. ${ }^{\text {I }}$

Finalmente, el mando militar de las alcaldías también se halla subordinado al de los gobernadores de Galicia y Vizcaya en cuanto capitanes generales de sus gobernaciones. Pero este título, que es una reminiscencia de los tiempos de la conquista y de los adelantamientos, tiene escasa y discutida aplicación en la práctica, siendo éste el campo de las más visibles ingerencias o intromisiones del virrey, que habitualmente se mueve en él como único e indiscutido capitán general efectivo.

\section{CREACión y PROVISIÓN DE LAS ALCALdias}

Tras de las alcaldías y corregimientos creados por Guzmán e Ibarra, que sólo fueron tres, que sepamos, la audiencia creó corregimientos en el distrito de Cuiiacán, que pervivieron algún tiempo en el XVII, y Urdiñola nos informó de la alcaldía que los de Guadalajara se apresuraron a erigir en las minas de Carantapa. Los gobernadores de Nueva Vizcaya, por su parte, hacen y deshacen a voluntad, creando y suprimiendo alcaldías según se ha visto. Jamás se puso en tela de juicio esta facultad en ninguno de los dos casos, aunque en el último sería más discutible.

La única excepción a lo dicho, notable por demás, es la de Sonora, alcaldía mayor que nace amparada por una capitulación de don Pedro de Perea con el virrey Cadereita. Ello ha de expli-

II Guadalajara I54, núm. 3, fols. I I 7v.-120. 
carse por la suposición de que Perea debió ofrecer acometer la entrada y poblamiento del país a su costa, garantizándole el virrey por su parte determinadas prerrogativas segín las leyes de I 573 . Sin embargo, el gobernador de Nueva Vizcaya no debía considerarse despojado de facultad semejante, pues en i667 Oca Sarmiento daba comisión al capitán Pedro de Valencia para que desde Sonora entrase a hacer descubrimientos de minerales y puertos de mar, admitiendo en su compañía a toda la gente que voluntariamente quisiera seguirle, reservándose Oca el dar cuenta al rey de los resultados de tal actividad y disponer lo que conviniese. Ia

Pasemos a tratar de la provisión de las alcaldías, punto en el que habremos de hacer varias distinciones. Provee por derecho estos puestos el presidente-gohernador de Nueva Galicia en su enclave de Culiacán. Por costumbre tolerada ejercita esta misma función en sus provincias el gobernador de Nueva Vizcaya, tal como lo había hecho Ibarra, y nadie puso reparo en ello hasta I630, en que el presidente don Diego Núñez Morquecho, al llegar a hacerse cargo de la audiencia, advierte "que los gobernadores de la Nueva Vizcaya han introducido y apropiado para sí los títulos y provisiones de oficios de justicia que se proveen en las ciudades, villas y reales de minas que hay en el dicho reino ... y estos oficios se proveen por ıno y dos y más años", y pide que el rey determine a quién han de tocar estos nombranientos. ${ }^{13}$ En Madrid el asunto fue mirado con tolerancia por parte del fiscal de Consejo, que escribe que "por ahora no juzga ser conveniente que al gobernador de Nueva Vizcaya se le quite la provisión de los oficios y alcaldías mayores que en esta carta se refieren", aunque sin explicar su punto de vista, que bien pudo ser el de evitar una disensión más entre las autoridades indianas, y así el Consejo pudo resolver en esta cuestión con las palabras de "guárdese là costumbre". I4 Un decenio más tarde, el gobernador don

I2 Escribanía 397 A, cuaderno 2I, fols. 8ov.-8I.

I3 Niñez Morquecho a S. M. Guadalajara, 4 noviembre 1630. Guadalajara, s. Ibid.

I4 Respuesta fiscal de 7 agosto I63I y resolución del Consejo en 9. agosto. 
Luis de Valdés daba por sentado que a él correspondía exclusivamente el nombramiento de los ministros de justicia de toda la provincia. I5 La relación de las diecinueve alcaldías de Nueva Vizcaya enviada por Núnez Morquecho había sido recogido inmediatamente por Díez de la Calle para la formación de sus "Noticias". ${ }^{16}$

Hasta I67 I no vuelve a oírse hablar de la cuestión, cuando el fiscal de Guadalajara don Fernando de Haro y Monterroso escribe que los gobernadores de Vizcaya nombran más de veinticuatro alcaldías con el mismo título que aquella audiencia y el virrey en sus distritos. "No me meto ahora en ajustar la justificación de esta posesión porque no he tenido tiempo de reconocerlo; harélo y daré cuenta a V. M.". ${ }^{17}$ Pero ni volvió a tratar de la dudosa facultad del gobernador, ni se suscitó sobre ello inquietud en el Consejo como sería de esperar. Por lo demás, parece exagerado el número de alcaldías que Haro suponía en aquellas fechas. Algún tiempo después, un dictamen del licenciado don Fernando Jiménez Paniagua ante el Consejo de Indias sobre asunto similar reconocía al gobernador tan sólo la provisión interina de los oficios, ${ }^{18}$ pero de ello no se derivó modificación alguna de la práctica existente, que perdurará inalterada hasta el fin de la dominación española. Sobre este punto, pues, no hubo disputa, y sí sólo la advertencia por parte de algunos miembros

I5 Don Luis de Valdés a S. M., s. f. Guadalajara, 28.

I6 Biblioteca Nacional de Madrid, Mss. 3.048, fols. ror-163.

I7 Haro a S. M. Guadalajara, ig marzo I67I. Guadalajara, I I.

I 8 Informe en Madrid, I. $^{\circ}$ de abril de 1682 . Guadalajara, 29. Este dictamen, motivado por el nombramiento de regidores de Durango por Estrada en 1681 , dice así en su parte fundamental: "Supónese que los oficios de gobernadores de provincias, corregidores, alcaldes mayores de ciudades y pueblos de españoles, cabeceras de partidos principales de indios y oficiales de hacienda real y los demás se proveen por bu Majestad, pero hay tres tiempos de provisión de ínterin en las vacantes: el primero toca al gobernador de aquel partido y territorio; el segundo, al presidente de la audiencia, que excluye al primero; el tercero al virrey, que tiene la superior gobernación y excluye al segundo...". Según Paniagua, otros oficios los proveen en propiedad, "por leyes y estilo", los virreyes y presidentes, "pero de la provisión en interin no están excluidos los gobernadores". 
del tribumal de Guadalajara de la irregularidad con que procedía el gobernador de Durango.

Con pretexto de la superior autoridad de su cargo, introdujéronse los virreyes a nombrar alcaldes mayores de Sinaloa, desde I640, aunque siempre se reconoció que esta provincia era parte de la gobernación de Nueva Vizcaya; los virreyes procedían con esto a ampliar la facultad que anteriormente habían tenido de nonbbrar los capitanes del presidio allí erigido, respaldando más tarde su comportamiento en el hecho de constituir Sinaloa una base para la conquista de Californias, que les estaba encomendada.

Finalmente, el mismo rey avocó a sí desde i687 la provisión del cargo de alcalde mayor de Sinaloa, movido por el interés de percibir un donativo pecuniario a cambio de la merced, con esta intervención dio lugar a graves problemas de competencia. De modo inverso, cuando el rey comenzó a proveer también la alcaldía de Sonora, el virrey pudo también nombrar alcaldes mayores de esta provincia en defecto de los provistos. Tal es el caso de Gironza en la ḱ1tima década del XVII.

\section{TÍTULO DE ALCALdE MAYOR}

El título es expediclo por la secretaría de la autoridad que en cada momento efectúa la provisión de las alcaldías, y así dan títulos la audiencia, el gobernador, el virrey y el rey. Sólo de la audiencia no hemos topado con un título original o en copia. De los otros tres casos abundan los ejemplares. Insertaremos algunos, que volverán a sernos de utilidad más adelante. Véase el dado por don Bartolomé de Estrada, gobernador de Nueva Vizcaya a un alcalde de Ostimuri, don Francisco de Iglesias, en $\mathrm{Pa}$ rral, i7 de enero de I680. I9

I9 Escribanía $400 \mathrm{~A}$, pieza I. ${ }^{\mathrm{a}}$, fols, rov.-I 2v, 
Intitulación

Motivación

Méritos del c'esignado

Nombramiento de alcalde mayor y capitán a guerra

Atribuciones

Vara

Justicia

Asesor letrado

Indios
El general don Bartolomé de Estrada Ramírez, caballero del orden de Santiago, gobernador y capitán general de este reino y provincias de la Nueva Vizcaya por S. M. etc. Por cuanto el oficio de alcalde mayor del real de San Ildefonso de Ostimuri que servía el capitán don Simón Francisco de la Herrán $y$ en quien concurren las partes y prendas y calidades que se requieren, y porque éstas y otras muchas concurren en la del capitán don Francisco de Iglesias residente en este real, $y$ atento a que estoy informado que ha servido a $S$. $M$. en todas las ocasiones que se han ofrecido de su real servicio y espero lo continuará en lo de adelante, por el presente elijo y nombro por alcalde mayor y capitán a guerra al dicho capitán don Francisco de Iglesias, de dicho real de San Ildefonso de Ostimuri y su jurisdicción, según y como lo ha tenido y usado y ejercido el dicho su antecesor, para que como tal lo use y ejerza en todos los casos y cosas que a él tocare, y alce vara de la real justicia y conocer de todas las causas civiles y criminales que estuvieren pendientes como las que en adelante se pueden ofrecer, y todas sustanciarlas y determinarlas como hallare por derecho, conque las graves, arduas y dificultosas tenga obligación de sentenciarlas con parecer de asesor letrado, y tendrá particular cuidado de que en todo se administre justicia con igualdad y rectitud, y que en las causas de los pobres y viudas sean amparadas, y que los indios de su jurisdicción no sean vejados 
Defensa de la frontera

Sosteniniento de la autoridad real

Salario

Libros de cuenta y razón

Duración del mando

Bienes de difuntos

Juramento

Toma de razón en Cajas Reales y media annata ni molestados por ninguna persona y cque sean bien industriados $y$ enseñados en las cosas de nuestra fe católica, que acudan a la doctrina y rezo de ella y que vivan recogidos en sus pueblos, y no en los cerros y barrancos, sino en política, y que hagan sus sementeras y las cojan en sazón, y críen gallinas, y cuando hubiere noticia de los enemigos recorrerá las fronteras de su jurisdicción porque se eviten los daños que suelen liacer y no consentirá qute ningtna person alce vara de la real justicia sin su licencia o de quien se la deba dar, ni que ningún juez eclesiástico prenda a ningún seglar sin cute primero imparta el real auxilio, y por el trabajo y octrpación del derecho del dicho oficio le señalo 200 pesos en reales librados en gastos de justicia Ios que hubiere y se cat1saren en su tiempo, y tendrá libro de cuenta y razón así por lo que toca a dichos gastos de justicia como a la real cámara, y se entiende este oficio por tiempo de un año contado desde el día que tomare posesión de él o más la voluntad de S. M. y mía en su real nombre, y tendrá cuidado asimismo de que en las causas que hubiere de los abintestatos y a sus bienes se les dé el cobro conveniente, $y$ antes de empezar a ejercer dicho oficio hará el juramento y solemnidad que se requiere de lo usar bien y legalmente, y presentará este título ante los oficiales de la real hacienda y ca ja de la ciudad de Durango de la fecha en seis meses primeros y siguientes para que tomen razón de él y cobren lo 
Toma de posesión

Obediencia de los vecinos

Tenientes de alcalde ma yor

Honras

Expedición del título

Refrendo

Toma de razón en libro de gobierno

Data

que a S. M. se le debiere por razón del derecho de la media annata, y mando al dicho st1 antecesor que luego le entregue la vara de la real justicia y le admita al uso y ejercicio del dicho oficio, que yo desde luego le he por admitido, y a todos los vecinos estantes y habitantes en el dicho real y su jurisdicción hayan y tengan y respeten al susodicho por tal alcalde mayor y capitán a guerra, cumplan y guarden sus órdenes y mandatos por escrito o de palabra, pena de las que les impusiere, que para las ejecutar en los inobedientes y nombrar el teniente 0 tenientes que fueren necesarios le doy poder y facultad según y como puedo y la tengo de S. M., y le guardarán las honras, preminencias y prerrogativas que por derecho le competen y le son concedidas, para lo cual mandé despachar el presente firmado de mi mano, sellado con el sello de mis armas y refrendado del infrascrito escribano de S. M., quien lo asentará en el libro de gobierno. Dado en el real y minas de San José del Parral en I7 días del mes de enero de mil y seiscientos y ochenta años. Don Bartolomé de Estrada. Por mandado del señor gobernador y capitán general, Miguel de Aranda, escribano real.

Hemos ido señalando al margen los puntos más importantes que toca la extensa redacción del documento con objeto de que nos ilustre todo to posible sobre la institución del alcalde mayor. Se echará de ver la diferencia con el siguiente despacho ${ }^{20}$ de alcalde

20 Escribanía I8I B, fols. 29-34V. 
mayor de Sinaloa expedido a don Domingo Terán de los Rios por el virrey conde de Paredes, en México, It de febrero de 1686.

Intitulación real

Acterdo del virrey

Motivación

Unión de los mandos

Memorial del provisto
Don Carlos... Por cuanto con acuerdo de don Tomás Antonio Lorenzo... tengo proveído por mi gobernador y teniente de capitán general de las provincias de Sinaloa y capitán de sus presidios al capitán don Domingo Terán, y respecto de que el almirante don Isidro de Atondo y Antillón su antecesor, obtuvo los dichos cargos con todo lo político de dichas provincias por ra-. zón del nuevo descubrimiento de la California, reducción de sus habitantes a nuestra santa fe católica y demás motivos y funclamentos que para ello hubo al tiempo y cuando se proveyó el dicho almirante que hoy subsisten en mayor grado para su población, descubrimiento y adelantamiento en servicio de Dios nuestro Señor, y aumento de mi real corona, como está resuelto por diferentes juntas generales y lo tengo mandado por mis reales cédulas para que junto con lo militar esté lo político y se dé la mano lo uno a lo otro para la más breve y pronta ejecución de lo que se ofreciere tocante a ni real servicio, como se percibe del memorial que el dicho capitán don Domingo Terán puso en manos del dicho mi virrey que con la respuesta que dio el licenciado don Pedro de la Bastida de mi consejo fiscal de ciicha mi real audiencia de la ciudad de México es como se sigue: Excmo. Sr.: El capitán don Domingo Terán de los Ríos dice 
Socorros militares $y$ de bastimentos a California que la grandeza de V. E. fue servido de honrarle con los puestos de gobernador teniente de capitán general de las provincias de $\mathrm{Si}$ naloa y capitán de la gente de su presidio cuyos cargos obtuvo no sólo en lo militar cion Isidro de Atondo sino también en lo político en conformidad de órdenes de V. E. con resolución de juntas generales que mo-. tivaron las razones de congruencia que para ello asistieron y que después vino aprobadc por S. M. en diferentes reales cédulas y estos fundamentos para dicha determinación son los mismos que hoy existen para que estén juntos en un sujeto lo político y lo militar, así por lo principal de haber de asistir al presidio, soldados y misioneros (como está resuelto en aquellas islas) para la conversión de aquellos infieles, como para las conducciones de bastimentos que se han de hacer para este efecto desde la dicha provincia de Sinaloa y despachos ordinarios de las embarcaciones que han de conducir todo lo necesario, y por esto es preciso se valga de una y otra jurisdicción sin que sea necesario interpolación de otra persona pues de lo contrario resultarían grandes inconvcnientes y atrasos a la precisa y pronta ejecución de las órdenes de V. E. en este particular, quedando la monstruosidad de que se hizo reparo al principio que se le concedió dicho gobierno al dicho don Isidro de Atondo y que motivó el eficaz y único remedic. de que obtuviere lo político y militar, y inás cuando resulta en el servicio de S. M. a que 
Pugna con Nueva Viz- debe coincidir el gobernador del Parral, que caya

es sólo a quien resulta la corta conveniencia de nombrar un alcalde mayor, y demás de lo referido hacen al caso presente los litigios casos graves que han resultado y ocasionádose de semejantes perniciosos ejemplarcs y (sic) aquellas provincias con particulari. dad los que han acaecido y constan de autos en el Superior Gobierno de V. E., queriencio violentar al teniente puesto por el dicho clon Isidro violentándole en la jurisdicción $y$ queriendo limitársela el gobernador del $\mathrm{Pa}$ rral sólo por sus particulares fines embarazando no se consiguiesen los que conduzcan al mayor servicio de ambas majestades, y pues estos fueron los que motivaron dicha resolución y que hoy ejercen los mismos y que S. M. los tiene aprobados y que no puede resultar duda, antes sí de estar impartido el juicio de dos jurisdicciones en un mismo gobierno, y que siendo sujeto de la eleccićn de vuestra excelencia por la honra que le he merecido en hacerme merced de dichos cargos, sobre obtener su gobierno en una y otra jurisdicción política y militar tan necesaria para ejecución de las órdenes de V. E. y pronta obediencia para su cumplimiento como sc experimentará del celo que me asiste en el servicio de ambas majestades y desempeño de mis obligaciones, por lo cual a V. E. suplico se sirva concederme los despachus necesarios en la forma que se le dieron al dicho don Isidro pues existen los mismos fundamentos y razones de congruencia que 
motivaron a V. E. y a la Junta general por su determinación, que todo está aprobado por S. M., con que se conseguirá el fin principal a que aspira mi celo que es el mayor servicio de ambas majestades y pronta ejecución de las órdenes de V. E., de cuya grandeza espero esta merced, etc. Don Domingo de Terán. Excmo. Sr.: el fiscal de S. M. ha visto este memorial de don Domingo de Terán, gobernador proveído para las provincias de Sinaloa, cuyo contenido presupuesto dice que habiéndose capitulado con don Isidro de Atondo su antecesor el que se le diese este gobierno por razón de la conquista de Californias se resolvió con respuestas fiscales en junta general de 28 de novienıbre del año pasado de 78 que el Excmo. Sr. Arzobispo virrey le hiciese merced de dicho oficio de Sinaloa en lo político y militar en ínterin que durase dicha conquista, lo cıal con los demás puntos expresados en dicha junta aprobó S. M. por su real cédula de 29 de diciembre de 79, que está original y obedecida en el cuaderno segundo de las diiigencias de dicha conquista de Californias y con efecto se le despachó título de que ha usado sin embargo de algunas competencias que ha habido con los gobernadores de la Nueva Vizcaya, amparándole en la posesión que usó de dicho gobierno especialmente por junta general de 9 de octubre del año pasado de 85 , respecto de lo cual y en consideración de que no está acabada dicha conquista, porque aunque se ha comenzado to- 
divía falta tierra que descubrir y no se sábe si S. M. con vista de los informes que se le hicieron mandará se prosiga y que en el interin ha de haber allí alguna gente de presidio y religiosos para la conservación de los indios que se han reducido y puede ser se ofrezca para ello algunos socorros así de gente como de bastimentos de dicha provincia de Sinaloa a que asista el gobernador por su más fácil y pronto expediente, podiá V. E. siendo servido mandar se clen a dicho capitán don Domingo de Terán los despachos necesarios para lo político y militar de dicho oficio en la misma forma que se dieron a dicho don Isidro de Atondo, con advertencia que las apelaciones de lo politico tocan a la real audiencia de Guadala. jara y las de lo militar a V. E., y que d1-

Pase de la audiencia de Guadalajara

Conformidad del virrey

Nombramiento de alcalde mayor

Justicia chos despachos se hagan saber al Sr. Presidente y real audiencia de Guadalajara, por donde se pasen para que estén entendidos de su efecto. V. E. mandará lo mejor. Mé. xico y febrero I 3 de 1686 años. Licenciado don Pedro de la Bastida. Con la cual se coni* formó y con su acuerdo he tenido por bien de dar la presente, por la cual os nomibro por mi alcalde mayor de las dichas provincias para que juntamente con lo mititar useis y ejerzais lo político, conociendo de todos los pleitos, causas y negocios civiles y criminales que ocurrieren y se ofrecieren en las dichas provincias y sus jurisdicciones sustanciándolas y determinándolas conforme a derecho y justicia, annque intervenga 
Apelaciones en 10 político y militar

Duración del cargo

Patronato Real

Indios pena de muerte $u$ otra cualquiera corporal, con que no ejecuteis el tenor de vuestras sentencias sin otorgar las apelaciones en lo político para mi real audiencia de la ciudad de Guadalajara y en lo militar para ante el di. cho mi virrey y junta de mi Consejo de Guerra de Indias, y con que en las causas que no tstuviere probada la culpa o por arbitrio absolviéreis a los reos y que condenáreis en penas extraordinarias enviaréis los presos en la. forma referida a donde toquen, en el cual dicho cargo os proveo y nombro por el tiempo que estuviéreis proveído en los demás ex. presados y sin salario alguno, respecto de tenerlo asignado en los dichos cargos, sin consentir que en vuestra jurisdicción se fun. den iglesias ni otros conventos sin expresa licencia nuestra o de quien os la pueda dar, y os encargo y mando tengais especial cuidado de que los naturales que estuvieren convertidos y los que de nuevo se convirtieren a nuestra santa ley católica sean bien industriados y doctrinados en ella procurándolos reducir con todo amor y paz, evitándoles las idolatrías y otros pecados, procurando en el todo su aumento, conversión y conservación, sin que de ningún modo tengan por donde evadirse, sin tomarles ni llevarles derechos ni sus bienes de comunidad prestados ni en otra manera, procurando se congreguen y vivan en pueblos y hagan sus jacales y casas y que siembren algunas sementeras de suerte que tengan con qué pasar, guardando y cumpliendo mis reales provi- 
Descubrimiento de California

Vara

Obediencia de los vecinos y de los indios

Penas

Exclusión de las castas

California

Pase de la audiencia de Guadalajara

Data siones, mandamientos y despachos como en ellos se contuviere, según y como lo hizo, pudo, y debió hacer el dicho don Isidro de Atondo vuestro antecesor, procurando st consiga en el todo el nuevo descubrimiento que está empezado y según y en la forma y conforme a las órdenes que se os dieren, que para todo ello y lo usar y ejercer en todos los casos y cosas a él anejas y concernientes y alzar traer vara de mi real justicia os doy el poder y facultad que de derecho se requiere, con lo cual mando a los vecinos estantes y habitantes en la dicha jurisdicción y a los naturales de ella os hayan y tengan por tal su alcalde mayor, os respeten y obedezcan y cumplan vuestros autos y mandatos a los plazos y so las penas que les pusiéreis $y$ según $y$ como se ha acostumbrado con vuestros antecesores, con que no nombreis por teniente ni alguacil a ningún mestizo ni mulato, y respecto de que hasta ahora no se ha resuelto en mi Consejo Real el punto de la prosecución del descubrimiento de dichas Californias obsevaréis el orden que para ello os diere el dicho mi virrey sin exceder de él en manera alguna, para lo cual y su mejor uso y ejercicio haréis y os presentaréis con este mi título en la real audiencia de Guadalajara, adonde lo haréis saber a mi presidente y oidores para que le den paso y lo tengan entendido. En la ciudad de México a I4 de febrero de 686 años. El conde de Paredes, marqués de la Laguna... Atento a que por esta ocupación no se le señala sa- 
Fianza de media annata

Otorgamiento de dicha fianza

Fiador de residencia

Toma de razón y contaduría lario alguno al contenido y que en los demás títulos y despachos tengo ya puestas las razones que a cada uno tocan, por lo que a ésta pertenece dará fianza el contenido de lo que se causare procedido de la renta del derecho de la media annata y que se causare en su jurisdicción de los nombramientos de teniente y alguacil que nombrare en la forma que se acostumbra con los demás alcaldes mayores de este reino. México y febrero ió de I686 años. Doctor don Antonio de Rojas. El contenido en este real título otorgó la fianza que se ordena en la glosa antecedente y queda en la contaduría del real derecho de la media annata por lo que pertenece a dicho derecho. México y febrero 21 de I686 años. Don Antonio de Deza y Ulloa. Don Nicolás del Rosal y Ríos. El contenido en este real título dio por fiador de residencia a don Antonio de Morales. México y febrero 22 de I686. Francisco de Montoya, escribano. Tomóse razón del real título de ésta y las tres hojas a ella antecedentes en la contaduría de real hacienda de esta Nueva España de mi cargo de pedimiento del contenido. México y febrero 22 de 1686 años. Don Antonio de Deza y Ulloa.

Veamos, en fin, un título despachado en Madrid a un justicia mayor de Sinaloa, don Manuel de Agramont, en 30 de mayo de I687. ${ }^{21}$ Sus diferencias respecto de los anteriores son perceptibles al primer golpe de vista.

21 Ibid., fol, 14-18. 
Intitulación

Motivación

Méritos del provisto

Merced

Duración del cargo

Salario
Don Carlos por la gracia de Dios, rey de Castilla, de León, de Aragón, de las Dos Sicilias, de Jertusalén, de Navarra, de Granada, de Toledo, de Valencia, de Galicia, de Mallorca, de Sevilla, de Cerdeña, de Córdobã, de Córcega, de Murcia, de Jaén, de los Algarbes, de Algeciras, de Gibraltar, de las Islas de Canaria, de las Indias orientales occidentales, islas y Tierra Firme del Mar Océano, Archiduque de Austria, Duque de Borgoña, de Brabante y Milán, Conde de Habsburgo, de Flandes, de Tirol y Barcelona, Señor de Vizcaya y de Molina, etc. Por cuanto conviene a mi servicio proveer la futura del puesto de capitán y gobernador del presidio de Sinaloa en las provincias de la Nueva Vizcaya, y atendiendo a las buenas partes y méritos que concurren en vos el capitán don Manuel de Agramont y a lo que me habéis servido en la Armada del Océat1o, Flandes y Cataluña, y esperando lo continuaréis con la fidelidad que sois obligado; he resuelto haceros merced por mi real decreto de dieciséis de mayo de este año de mil seiscientos y ochenta y siete (como por la presente os la hago) de la dicha futura del puesto de capitán y gobernador del dicho presidio de Sinaloa por vuestra vida, para cuando vaque por la persona que actualmente le ejerce, con cuyo oficio habéis de gozar e! mismo salario y emolumentos que han gozado vuestros antecesores y en la misma forma y manera que le estuviere gozando la persona que al presente le sirve sin que en 
Juramento

Toma de posesión

Justicia

Tenientes esto se altere cosa alguna de la costumbre que en ello ha habido; y por esta mi carta niando al gobernador y los del mi Consejo de las Indias tomen y reciban de vos el dicho don Manuel de Agramont el juramento con la solemnidad que en tal caso se requiere y debéis hacer de que bien y fielmente usaréis el dicho puesto, y habiéndole hecho $r$ llegado el caso de entrar a ejercer y servir dicho empleo de capitán y gobernador del presidio de Sinaloa, ellos y todos los caballeros, escuderos, oficiales y hombres buenos de la jurisdicción del dicho presidio os hayan y tengan por tal capitán y gobernador de él durante vuestra vida, y os dejen libremente oir, librar y conocer de todos los pleitos y causas así civiles como criminales que en la dicha jurisdicción hubiere y de que vos pudiéredes de conocer como tal capitan y gobernador, y proveer todas las otras cosas que los demás capitanes y gobernadores del dicho presidio de Sinaloa podían y debían proveer y tomar y recibir cualesquier pesquisas e informaciones en los casos y cosas de derecho permisas que entendiéredes que a mi servicio, ejecución de mi justicia y buena gobernación del dicho puesto y su jurisdicción convenga, y hayáis de llevar y llevéis vos y vuestros lugarte. nientes si fuere costumbre que los haya en el dicho presidio los derechos a él anejos, debidos y pertenecientes, y que los dichos tenientes que así nombráredes, siendo letrados y llevándolos de estos reinos, sean 
aprobados en mi Consejo de las Indias, y 120 los habiendo de llevar, sino que los ha$y$ áis de nombrar en aquellas partes, en tal cáso seáis obligado a presentarlos en mi audiencia real de la ciudad de Guadalajara, y que no sean los que acaban de ser en el quinquenio o trienio pasado, ni naturales de la jurisdicción del dicho presidio, sin haber dado primero residencia del tiempo que 10 hubieren sido. Y mando que para usar $y$ ejercer dicho puesto todos se conformen con vos y os obedezcan y acaten y cumplan vuestros mandamientos y que en ello ni cn

Ingreso inmediato al mando

Fianzas de residencia

¿Tributos? parte de ello no os pongan ni consientan poner embarazo ni impedimento alguno, que yo por la presente os recibo y he por recibido a él y a su gusto y ejercicio, y os doy poder y facultad para le usar y ejercer caso que por ellos o algunos de ellos a él no seáis recibidos, con tanto que primero $y$ antes que lo seáis hayáis de dar fianzas legas, llanas y abonadas en la cantidad que se os señalare por el cabildo de la ciudad, villa o lugar que fuere cabecera de dicho qresidio de que bien y fielmente usaréis este empleo, cumpliréis con vuestras obligaciones, leyes reales y capítulos de corregidores y que cobraréis los tributos que los indios de vuestro distrito debieren pagar y no lo haciendo satisfaréis de vuestra hacienda los rezagos que en vuestro tiempo se causaren, haciendo para ello padrones de los indios tributarios al tiempo que entráredes a servir, como está dispuesto por la ordenanza 
gue hizo don Francisco de Toledo siendo virrey de las provincias del Perú, que estí confirmada por el rey mi señor y bisabuelo (que santa gloria haya) so pena que no cobrando los tributos pagarán vuestros fiadores lo que de ellos dejáredes de cobrar $\sin$ que sobre esto se os admitan ningunas cliligencias ni descargos que pretendiéredes dar y más lo juzgado y sentenciado en vuestra residencia como fiadores del juzgado $y$ sentenciado. $Y$ porque he sido informado que sin embargo de estar prohibido por diferentes cédulas y ordenanzas reales que ningunos de los gobernadores y corregidores de las Indias puedan sacar de las cajas de comunidades de los indios la plata que está e11 ellas, contraviniendo a esto la han sacado algunos para emplearla en sus tratos y granjerías y usos propios de que se ha seguido mucho perjuicio a los indios, habéis de estar advertido que en ninguna manera habéis de tocar a las cajas de comunidades por ningún caso ni para ningún efecto que Indios sea, ni serviros de los indios, ni acuparlos en ningunos ministerios de vuestro servicio, con apercibimiento que se os hará cargo en vuestra residencia y seréis castigado por ello con demostración; y porque asimismo se ha entendido en mi Consejo Real de las Indias las vejaciones y agravios que reciben los indios cuando van los virreyes, presidentes $u$ oidores de las audiencias y los gobernadores de las Indias a servir sus puestos, obligándoles a que les den bastimentos 
y bagajes sin pagarles lo que justannente se les debe dar por ellos, os mando que cuando vais a tomar posesión de este puesto ni cuando salgáis a la visita ordinaria de 1 . tierra ni a otras comisiones no obliguéis a los indios a que os den bastimentos ni bagajes si esto no fuere voluntario en ellos y pagándoles lo que justamente se les debiere dar por ello según el común precio y estimación de las cosas que hubiérecles 11:nester, $\sin$ hacerles perjuicio ni vejación alguna, por lo que se clebe atender a su alivio y conservación y ser materia tan escruptilosa y digna de todo refaro lo contrario, y así observaréis lo refericlo precisa y puntualmente estando advertido que de cualquiera contravención que en esto haya se os hará cargo en vuestra residencia, siendo (aipitulo expreso de ella para castigaros con Arribalas y extravíos de metales demostración como transgresor de esta ordien. Y asinismo estaréis advertido que tre mandado guardar y cumplir lo dispuesto por cédula del rey mi señor y padre de cuatro de noviembre del año pasado de mil y. seiscientos $y$ sesenta y uno en que (entre otras cosas) dispone que en las causas y pleitos de arribadas a los prertos de las Indias, contrataciones que en ellos se hicierein, extravíos de plata 1 otros géneros prohibidos sacar y llevar de ellos de tunas partes a otras así los que estuvieren pendientes como ios que adelante se of recieren, se admitan contra cualesquiera que resultaren culpados atinque sean mis gobernadores 11 otros cua- 
lesquiera ministros iníos testigos singulares que depongan de diferentes hechos y no contesten en nada y aunque sean menos idó. neos, de suerte que siendo tres los que depongan se laya s11 deposición por bastante y legítima probanza de estos delitos aunque sean singulares, y cada uno deponga en ellos de diferente hecho, y que por esta probanza se debía imponer la pena establecida por diferentes cédulas y ordenanzas y que no pudiendo ser los testigos que se examinaren en el sumario de estas causas ratificados en plenario por su ausencia, larga distancia o otro justo impedimento baste a abonarse de suerte que abonados prueben en el plenario de la misma manera que si estuviesen legitimamente ratificados, y que en los casos de estos delitos no puedan los reos oponer privilegio alguno de fuero, ni se les admita aunque sean caballeros de las Ordenes Militares, capitanes, soldados de cualesquiera milicias, oficiales titulares, familiares de la Santa Inquisición, ministros de la Santa Cruzada o otros algunos no expresados, y au11. que tengan igual o mayor privilegio, y que las sentencias que en ellos se dieren sean ejecutivas y se ejecuten sin embargo de cualquier apelación o suplicación que de ellos se interpusiere, la cual tenga solamente el efecto devolutivo para que en su grado se pueda confirmar o revocar como fuere de justicia. $Y$ últimamente reconociéndose lo mucho que importaba usar de todos los medios que pudiesen conducir al remedio de 
tantos daños como se seguían de no poderse averiguar la culpa de los delincuentes se resolvió que demás de lo referido fuese bastante probanza las noticias que diesen los ministros y personas públicas a quien por el grado en que estuviesen empleados se les cliese justamente fe y créclito, mayormente en excesos y delitos de tan dificultosa probanza por la mano y antoridad que tienen los que incurren en ellos y que así en las causas de arribadas y comercio que estuvieren pendientes $y$ adelante se of recieren en $\mathrm{mi}$ Consejo de las Indias tanto de naturales como de extranjeros hicieren y hagan tal fe y probanza las dichas noticias que concurriendo con ellas otros indicios y conjeturas pudiesen y puedan pasar los jueces que conocieren de las dichas causas a conclenar los que resultaren reos, así gobernadores como oficiales de mi real hacienda y otras ctralescuiera personas en pena ordinaria 0 extraordinaria según la calidad de las dichas noticias $y$ de los indicios y conjeturas qu1e concurriesen, conque por este medio senn castigados los que cometieren semejantes delitos contraviniendo a las órdenes y cédulas

Cesión del mando del antecesor dadas. $Y$ asimismo cuando a las personas que tuvieren las varas de mi justicia en el dicho presidio y su población o poblaciones que luego que por vos fuesen requeridos con esta mi provisión os las den y entreguen cuando llegue el caso de tomar la posesión de dicho puesto y no usen más de sus oficios so las penas en que caen e incurren las 
Penas de Cámara

Facultad de desterrar
Ratificación del poder del rey

Salario personas que usan de oficios públicos y reales para que no tienen poder y factultad, que yo por la presente les suspendo y he po: suspendidos de ellos, y las penas que vos y los dichos vutestros lugartenientes hiciéredes para mi Cámara y fisco las ejecutaréis y haréis ejecutar, dar y entregar a los oficiales de mi real hacienda de la Ciudad de Durango. $Y$ si entendiéredes cumplir a mi servicio y a la ejecución de mi justicia que cualquier personas que ahora están y adelante estuvieren en la jurisdicción del dicho presidio salgan fuera de ella y se vengan a estos Reinos se lo mandaréis de mi parte y los haréis salir conforme a la pragmática que sobre esto habla, dando a los que así desterráredes la causa por que lo hacéis, y si os pareciere que sea secreta se la daréis cerrada y sellada, y un traslado de ella enviaréis por dos vías al dicho mi Consejo de las Indias para que yo sea informado de ello. Pero estaréis advertido que cuando así hubiéredes de desterrar alguna persona ha de ser con muly gran causa. Para todo lo cual y cada cosa y parte de ello os doy el poder $y$ facultad que en tal caso se requiere y fuere necesario, y es mi voluntad que hayáis y llevéis de salario en cada año el dicho puesto (como queda referido) otros tantos maravedís como han tenido y llevado vuestros antecesores en él y el que actualmente le estuviere ejerciendo, los cuales mando se os paguen de los maravedís y en la forma que a ellos se les pagaba desde el día que 
Testimonio de posesión

Media annata

Toma de razón jor testimonio signado de escribano público constare haber entrado a ejercerle. Y que referido se guarde, cumpla y ejecute enviando testimonio al dicho mi Consejo de las Indias en la primera ocasión que se ofrezca del día en que iomáredes la posesión de él. Y mando a los dichos oficiales de mi Real Hacienda de la dicha ciudad de Durango hagan averiguación del salario, emolumentos y aprovechamientos que tuviere el dicho puesto y que antes que se os de la posesión de él cobren de vos el dicho don $\mathrm{Ma}$ nuel Agramont la media annata que debiéredes conforme a reglas de este derecho si la hubieren pagado vuestros antecesores, y que lo que importare lo remitan a estos reinos con la demás hacienda mía a poder del Tesorero General de este derecho, guardando en ello lo dispuesto por el arancel de él y órdenes que últimamente están dadas, y de esta mi provisión tomarán la razón don Luis Antonio Daza mi secretario del Registro General de Mercedes o por su ausencia o enfermedad don Antonio de Somoza, caballero de la Orden de Santiago, mi secretario y oficial mayor de la misma secretaría dentro de los cuatro meses de su data precisamente, $y \sin$ haberlo hecho no se tome la razón en otro algún oficio ni ningún tribunal, ministro o persona a quien perteneciere su cumplimiento se le de, y no ejecutándose así quede nula esta merced. Y asimismo tomarán la razón mis contadores de cuentas qu1 residen en mi Consejo Real de las Indias, e! 
Data

Firma del rey

\section{Refrendo}

Toma de razón en

Secretaría de Mercedes

Firmas de tres consejeros de Indias

Razón de la Contaduría del Consejo

Id. de media annata

Sello y registro del Sello

Juramento de la media annata de esta Corte y los dichos mis Oficiales Reales de Durango. Dada en Madrid a treinta de mayo de mil seiscientos y ochenta y siete años. $=$ Yo el rey. $=$ Yodon Antonio Ortíz de Otálora secretario del rey mi señor lo hice escribir por su mandado. V. M. lo mandó (rúbrica).= Queda ejecutado en la secretaría de Mercedes lo que S. M. manda. Madrid, 4 de junio de s687, don Antonio Fernández de Somoza 9 ducados. Registrado. $=$ Registrado. $=\mathrm{E} 1$ marqués de las (ilegible). El conde de Villaumbrosa, marqués conde de Castronuevo. $=$ José de Veitia. = Tomaron la razón los Contadores de Cuentas de S. M. que residen en su Consejo Real de las Indias. Don Miguel Antonio de Cabrera. Don Andrés de Peñaranda. $=$ Tomé la razón por 10 que toca al derecho de la media annata, Don Renier de Lagasca. $=$ Registrado, Don Tomás de Salazar. $=($ Sello real $)=$ Por el Gran Chanciller, Don Tomás de Salazar, su teniente $=374$ maravedises $=$ Don Diego de Urbina Samaniego, escribano de cámara del rey nuestro señor en su Consejo Real de las Indias y Junta de Guerra de él certifico que hoy día de la fecha presentó ante los señores gobernador y del dicho real Consejo el capitán don Manuel de Agramont este real título que tiene para el puesto de capitán y gobernador del presidio de Sinaloa en la provincia de la Nueva Vizcaya, el cual fue leído por mí y visto, oído y obedecido por dichos señores mandaron que hi- 
Razún en la Contaduría de Contratación ese el juramento que por él se manda y : dicho don Manuel de Agramont le hizo y yo se lo recibí en presencia de los dichos señores en la forma y con la solemnidad que en el caso se acostumbra y para que de ello conste doy la presente en Madrid, a 6 dias del mes de junio de mil seiscientos y ochenta $y$ sicte años. Diego de Urbina Samaniego= (certificación por tres escribanos de la firma anterior) = En los libros de la Contaduría principal de la Casa de lá Contratación de las Indias se tomó la razón del real título de S. M. escrito en las cuatro hojas antes de ésta. Cádiz, el lii de junio de M dclxxxvii años. El conde de la Calzada. Francisco de Lá(zaro) de San Millán.= Dun cados i 70 , asentado.

La real provisión antecedente es un magnífico documento, magnificamente inadecuado, según puede observarse, a las obligaciones concretas de un alcalde de Sinaloa. Su aspecto más destacado es, sin duda, el de crear un capitán vitalicio, con todas las facultades de gobiemo y justicia de $u 11$ gobernador, sin la menor alusión a dependencia de cualquier tipo al de Nueva Vizcaya, aunque esto, por otra parte, quedaba establecido en la real cédula de 22 de diciembre de 1685 , de que se hablará más adelante, a lo menos en lo militar.

$\mathrm{Ya}$ se advierte que en los títulos tradicionales el alcalde mayor suele tener aneja la función de "capitán a guerra", esto es, jefe militar de su jurisdicción, y que en él -o en otros-- puede recaer el título de teniente de gobernador y capitán general, en nombramientos del de Ntueva Vizcaya, o el de gobernador y teniente de capitán general cuando el título es expedido por el virrey ; pero fuera de esto hay puntos más interesantes. 
DURACIÓN DEL MANDO Y SALARIO

La duración del mando es concepto que se omite en muchos títulos - por ejemplo, los de Berganza y Porter, dado por el virrey-, pero es más frecuente que aparezca al menos la frase "por el tiempo que fuese la voluntad de S. M. y mía en su nombre", y sobre todo la de "por tiempo de un año más o menos". Para el caso de las alcaldías provistas por los gobernadores de Nueva Vizcaya o por los presidentes de Guadalajara, esto significaba en la práctica que el alcalde mayor debía obtener la prórroga de su mandato por otro año, siendo así el espacio de dos el que solía permanecer uno de estos justicias al frente de cada provincia. En real cédula de 30 de junio de I666 se declararon tales prorrogaciones de segundo año por de justicia y no gracia, en fuerza de su costumbre. ${ }^{22}$ En 1668 los diputados del real de Copala solicitaban se mantuviese en el gobierno de la jurisdicción a don Alonso Pita de la Torre que había cumplido ya "sus dos años", lo que fue concedido por Oca Sarmiento. ${ }^{23}$

Para el caso de los alcaldes designados por el virrey, por la distancia de México a Sinaloa, el relevo no se hacía sino cada tres años, sin necesidad de que se pidieran las prórrogas, sin embargo de que el título expresaba la duración de "un año más o menos", y así declaró don Domingo Terán habérselo dicho el virrey Paredes cuando lo nombró, y lo confirmaron don Antonio de Morales Pastrana, antiguo oficial del Tribunal de Cuentas, y don Antonio Otermín, en I69o, con ocasión de la polémica entre Quirós y Agramont sobre la validez de sus respectivos títulos. ${ }^{24}$ Confirmación de otro tipo podemos nosotros mostrar indicando que en algunos títulos de Nuevo México -que eras como Sinaloa, uno de los empleos más remotos que proveía el virrey - sí que consta el tiempo de tres años más o menos: son

22 Escribanía is I B, fols, 85 v, -87.

23 Escribanía 397 A.

24 Escribania I 8 I B, tols. 77v.-79v. y 85v.-87. 
títulos de Otermín, de Gironza, de Renedo y de Posadas, entre I677 y. I686. ${ }^{25}$ En 1678 se proveyó Sinaloa por cinco años en Atondo y Antillón por virtud de capitulaciones hechas en este sentido con objeto de facilitar su empresa californiana, según se dirá más adelante. La real cédula de 22 de diciembre de 1685 vino a producir en Sinaloa el extraño efecto de crear un funcionario vitalicio, alcalde mayor, auncue no era ese el objetivo buscado, sino el de asegurar la carrera y posición de los capitanes de los presidios fronterizos. Pero lo cierto es que con esti característica se conservará el empleo hasta el momento de Huidobro, primer gobernador de las provincias unificadas, inclusive. No se olvidará, por otrá parte, el caso de Hurdaide, alcalde mayor de Sinaloa por espacio de casi treinta años, sin que nadie lo repugnase.

En cuanto al salario se advierten serias alteraciones en el transcurso del siglo y notables diferencias de unos a otros empleos, así como de los fondos de que se pagaban, que en Culiacán era de los de tributos, en Sinaloa y San Sebastián de las Cajas Reales, y en los demás lugares de los gastos de justicia.

En Culiacán, hasta el segundo tercio del XVII, se proveían no menos de dieciséis corregimientos aparte del de la villa. Conocemos sus honorarios a fines del XVI y según los recoge Díez de la Calle en $1637 .{ }^{26}$

$$
\text { I } 575 \mathrm{ca} \text {. }
$$

San Miguel de Culiacán Baila

Tacolimbo

Iguana y Jifo

Achiotla

El Vizcaíno

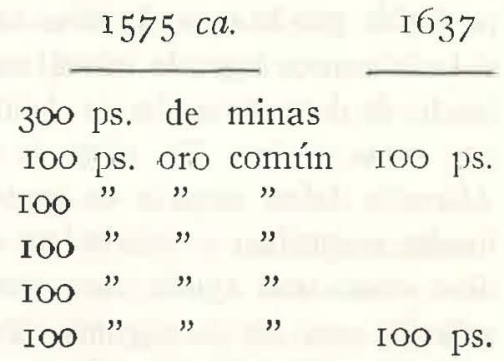

25 Ibid, fols. 67-69v.

26 Relación de hacia I575, en Guadalajara, 6. La de Díez de la Calle, an la Biblioteca Nacional de Madrid, Mss. 2.939. 
Tecuberito y Los Pescadores

Ayona

Cocala y los Guamuchiles

El Ostial, Guatometo y Navolato Ilarito

Tecurimeto

Cogota

Yegualito y El Pescadero

Chilobito

Navito y Ayabuto

Pueblo de Culiacán

Itlaje y Guzmanillo

$\frac{\text { I } 575 \mathrm{ca} .}{\text { I00 ps. de minas }}$

Cuspita y Tolobato

IOO " " " ,

I5O ps.

I70 " " $" 150$ ps.

I70 " $" \quad$ I0O ps.

$100 "$ " $" 100$ ps.

Acalo y Santisteban

I $50 ", \quad ", \quad "$

I $70 ", \quad "$,

I7O " $" \quad$ I 50 ps.

I00" " " I00 ps.

$200 " \quad " \quad$ I00 ps.

100 ps.

IOO ps.

IOO ps.

Alicama y Yebavito

200 ps.

Loto, Avilameto y La Galga 50 ps.

Soloneto

IOO ps.

Descontado el corregimiento de San Miguel, cuyo salario no recoge Díez de la Calle, el número sensiblemente igual de oficios de justicia al cabo de medio siglo transcurrido entre las dos relaciones resulta menos gravoso en el XVII que en el XVI. Es muy probable que la serie de tales cargos coincidentes fuese más amplia si hubiésemos logrado identificar algunos de ellos que habrían cambiado de denominación en el intervalo, según ocurría en Chiametla por estas fechas. En 1637 , la mitad del salario del corregidor de Alicama debía sacarse de gastos de justicia. Los vecinos de $\mathrm{Cu}$ liacán aceptaban y solicitaban estos cargos de gobierno de los indios como una ayuda para remediar su pobreza. Compárense sus salarios con los de algunas otras alcaldías de Nueva Galicia, que tenían consignaciones sobre uno o dos tipos de fondos, en la fecha intermedia de $\mathrm{x} 607,27$

27 Certificación de Pedro de Plaza, Guadalajara, 3 abril 1607. Guadalajara, 7. 
Fondos de

Tributos Justicia

Guachinango

\begin{tabular}{|c|c|c|}
\hline $3^{10}$ & + & $\begin{array}{l}\text { I00 ps. } \\
400 \text { ps. }\end{array}$ \\
\hline 130 & + & I 50 \\
\hline 3IO & + & $\begin{array}{r}200 \\
100\end{array}$ \\
\hline 250 & + & 200 \\
\hline 200 & + & 200 \\
\hline I 50 & + & $\begin{array}{r}250 \\
400\end{array}$ \\
\hline I 50 & + & $\begin{array}{l}25^{\circ} \\
700\end{array}$ \\
\hline linas) & + & $\begin{array}{l}125 \\
400\end{array}$ \\
\hline I IO & + & 200 \\
\hline IOO & + & 100 \\
\hline 100 & + & 100 \\
\hline 100 & + & IOO \\
\hline I 50 & + & 200 \\
\hline
\end{tabular}

Los oficios del enclave de Culiacán quedan todos, en general, muy por debajo de la remuneración de estos otros de la porción meridional de Nueva Galicia. Claro que la parte de salario que gravaba el fondo de gastos de justicia no era fácil de cobrar en los pueblos de solos indios, que por leyes estaban exentos de pagar costas en los juicios. El licenciado Gaspar de la Fuente escribía de los corregimientos de toda la jurisdicción de la audiencia que "los más son superfluos, en poblaciones estériles y de indios, do no sirven sino de consumir las pocas fuerzas de los afligidos naturales, para cuyas causas bastan sus alcaldes indios" 28

28 Gaspar de la Fuente a S. M: Guadalajara, 2 abril i603. Ibid. 
De las alcaldías de Piaxtla y Mazatlán a principios de siglo, ya se ha dicho que se pagaban del fruto de sus salinas, que se consumía en esto; también el alcalde de Chiametla percibía su paga de la sal vendida en su jurisdicción, y ascendía a trescientos pesos en la misma época. ${ }^{29}$ El capitán del presidio de San Sebastián -que en principio hemos de suponer ejercía al mismo tiempo la alcaldía mayor del distrito, pues no consta nada en contrario- tenía en 1632 un salario de 600 pesos, según el testimonio de López de Vicuña, ${ }^{\circ}$ y esta cantidad se libraba seguramente sobre las Cajas Reales, mientras que el capitán y justicia mayor de Sinaloa -que hasta la capitulación de Perea fue siempre una misma persona- gozaba 2.000 pesos, también sobre las arcas del rey, es decir, igual salario que el gobernador de Nueva Vizcaya. Siete lustros más tarde, los nombramientos expedidos por Oca Sarmiento, nos permiten conocer los salarios de las cinco alcaldías costeras por él provistas. ${ }^{3 x}$

Sonora 200 pesos de oro común

Ostimuri Ioo pesos en reales

Sinaloa I50 pesos en plata

Rosario Ioo pesos en plata

Copala roo pesos en plata +450 de oro común como capitán del presidio de San Sebastián.

Los salarios se perciben sobre condenaciones y gastos de justicia, salvo los $45^{\circ}$ pesos del capitán del presidio de San Sebastián que están consignados en Cajas de Durango. Los justicias manifestarán una y otra vez que no existían tales fondos y que en realidad no cobraban. Es la principal excusa bajo la que se tolera su comercio. Pero no había en las provincias otro caudal sobre el que imponer los salarios - hace ya mucho tiempo que no

29 Según las cuentas de Mesa y Barrasa en 1606 y 1607 . Guadalajara, 23.

30 Guadalajara, 133.

3I Escribania, 397 A. 
se habla de las antiguas salinas de toda Chiametla. En cambio, con la concentración de los antiguos oficios de Culiacán, el único alcalde mayor que ahora existe obtiene una consignación de 496 pesos 2 toms. 8 grs. sobre los tributos de la provincia, y 200 pesos más sobre el producto de las salinas: joo pesos en números redondos, por encima de todos los alcaldes vecinos, y efectivos adenuás porque ambas rentas son bastante seguras. ${ }^{2}$ Por cierto que también un soldado presidial, con 450 pesos anuales, cobraba más que los alcalcles de Nueva Vizcaya, incluso un misionero franciscano o jesuita percibía 350 pesos.

JURAMENTO Y TOMA DE POSESIÓN

Obtenido el título, debía el provisto jurar ante la autoridad que se le indicase la honradez y fidelidad en su desempeño, la conservación pacífica de las provincias que se le encomendaban y la defensa del misterio de la Purísima Concepción de la Virgen María, y luego ser recibido como tal justicia mayor por sus gobernados. En cuanto al juramento, ya se deja ver la diversidad lógica con que se prestaba bien ante el Consejo de Indias, o ante el virrey, audiencia o gobernador, o ante el cabildo o los principales vecinos de la cabecera, según la residencia del provisto en ei momento de ser designado para el cargo y la autoridad a que debiese su nombramiento. Pero, en fin de cuentas, todo se reducía siempre a la emisión del juramento con la fórmula y solemnidades prescritas por la ley.

Tocante a la forma de posesión se observan ya diferencias más dignas de tenerse en cuenta. Esta ceremonia, para no perder su contenido, debía efectuarse en el lugar en que habría de ejercer su jurisdicción el alcalde mayor, y ante un grupo representativo y revestido de alguna autoridad de los que habían de ser sus gobernados. Por supuesto, también era conveniente - aunque no necesaria- la presencia al acto del justicia saliente. Los cabildos

32 Según las cuentas de Calderón en I675. Guadalajara, 15. 
de españoles, en las villas en que los había, cumplian perfectamente el cometido que se deseaba para una tal celebración, en el curso de la cual se daba lectura a los títulos del nuevo justicia, y los miembros del ayuntamiento daban su obediencia a lo en ellos disputesto y entregaban al provisto la vara de la justicia, poniéndose constancia de todo ello en aquellos documentos. El mismo sentido de aceptación de la autoridad del alcalde entrante, aunque algo más desvaído, tiene la visita que con este motivo acostumbraban hacerle las "repúblicas" de los pueblos de indios de su distrito. Visita que era al mismo tiempo una cortesía y un acto de sumisión.

En algunas provincias - Sonora, Ostimuri, Rosario- no había cabildo por no haber villas de españoles; en otras, como es Sinaloa, se extinguió en un determinado momento. En tales casos, no faltaban los llamados "diputados del común", y en cualquier circunstancia el alcalde mayor se hacía reconocer por los vecinos españoles que hubiere en el lugar que le serviria de cahecera.

El caso para nosotros singular es aquel en que la autoridad que procede a la provisión anuncia al electo que, aunque no realizase toma de posesión, "os he y tengo ya por tal alcalde mayor", lo que en cierto modo significa un desprecio de la opinión de los gobernados y del derecho - nunca, que sepamos, ejercido por éstos- que tácitamente se les reconoce en la toma de posesión a aceptar o rechazar a la persona que se les presenta revestida con la autoridad suprema de la provincia.

\section{Funciones y DEPENDIENTES DEL JUSTICIA MAYoR}

Al alcalde mayor corresponde el gobierno del vecindario de españoles, la presidencia del cabildo de éstos cuando existe, y el gobierno y conservación de los indios. Tenía obligación de visitar su provincia una vez al año, y las tiendas de los reales o pueblos de españoles, cada cuatro meses. Por visitar una tienda percibía el alcalde como derechos un peso, y si no tenía escribano ni almo- 
tacén, doce reales; por una formación de inventario, ocho pesos. La visita de una hacienda de minas o de labor le reportaba otros ocho pesos. Además, una vez al año tenía que nombrar veedores que inspeccionaban el estado de las minas, y le correspondía luego extender la licencia para llevar las platas a ensayar a las cajas de Durango. 33 Pero como indica el otro apelativo de la institución que hemos colocado en el epígrafe, la principal misión del alcalde mayor es la administración de justicia a españoles y naturales. La vara de la justicia es el emblema del cargo, así citado en los títulos. En esto y en la dirección de los asuntos de guerra es donde más claramente se manifiesta su autoridad. Y todavía acumulan el juzgado de bienes de difuntos en su distrito. Realmente, a los alcaldes mayores del distrito de Nueva Vizcaya les faltan, por las especiales características de las provincias, otras interesantes funciones que sí se presentan en Culiacán y son típicas del cargo: la recaudación de tributos, el recuento y formación de matrículas de tributarios. Junto con éstas, otras ocupaciones del cobro de ramos de real hacienda faltan casi en absoluto - de la administración de salinas por cuenta de la Corona sólo tenemos noticia en Chiametla y Culiacán; de la venta de papel sellado en Sinaloa, y de la de naipes y pólvora en Sonora; las alcabalas se cobraban en Guadalajara de los géneros que iban a dirigirse por el camino de la costa; del mismo modo el ramo más valioso, de quintos y derechos de oro y plata de las minas de estas provincias. se pagahan en las Cajas de Parral o de Guadiana.

Para el desempeño de sus obligaciones tenían los alcaldes mayores la facultad de nombrar "tenientes de alcalde mayor y capitán a guerra" en los distritos en que solía dividirse su jurisdicción $\mathrm{y}$ en los principales reales de minas, sin remuneración al parecer. Así, mediado ya el siglo, los alcaldes mayores de Copala solían tener teniente nombrado en la villa de San Sebastián. Entrando el XVIII, el general Andrés de Rezábal había nombrado

33 Arancel de derechos dado por Don Francisco de Agramont y Arce. Parral, 3 enero 1679. Escribanía $400 \mathrm{~A}$, pieza 3, fols. 422-423v. 
un teniente general en la villa de Sinaloa, otro teniente general en el real y minas de Ntra. Sra. de la Concepción de los Alamos, y tres tenientes en el valle de San Juan Bautista de Mocorito, en Tucumena y en el Fuerte de Montesclaros; y del mismo modo nombraba un escribano de gobernación y guerra en la villa y un fiel y un alguacil en Alamos. El justicia mayor de Ostimuri ponía un teniente en Sahuaripa. Los alcaldes mayores de Sonora nombraban teniente en el real de San Juan Bautista, en el real de San Antonio y valle del Santo Nombre de Jesús de Bacantuche, en el real de Ntra. Sra. del Rosario de Nacosari; en el valle de Santa Ana de Tepache, en Nacatobori, en el valle de Teuricachi y en el real de San Miguel, en el de San Marcial y en el de San José de Opodepe y valle de Sonora, más un alguacil ejecutor.

Asesor nunca lo tuvieron los alcaldes mayores, porque no se conocieron abogados en este país durante todo el siglo; y el hecho extraña menos si se advierte que todavía en 1678 , para dictaminar una causa, tenía el gobernador de Nueva Vizcaya que remitirla a un letrado que residía en el real de Sombrerete. Algo menos acentuada es la carencia de escribanos: a principios de siglo todavía los nombraban los propios justicias -práctica prohibida luego por el rey- y así se hallaban en las actuaciones de los alcaldes de la época de Urdiñola y en las del capitán Hurdaide en particular; así debía ser el que un cronista cita en Culiacán. Después presenciamos la llegada de Luis de Morales, escribano real, a Sonora, donde ocuparía un tiempo la alcaldía mayor. Finalmente, el capitán Fuensaldaña, rival de Rezábal en el gobierno de Sinaloa, llevaría en su compañía un escribano de la audiencia de Guadalajara. A falta de escribano, naturalmente, el alcalde mayor o su teniente actuaban ante sí como jueces receptores y en presencia de testigos, en todos los autos de gobierno, guerra o justicia. Del mismo modo habían de ser ellos quienes conservasen los archivos de las respectivas jurisdicciones, no siempre en buen estado.

En casos de alguna importancia, el justicia mayor convoca- 
ba junta de vecinos: bien para organizar la defensa ante algún peligro, bien para poner remedio a una pentria de bastimentos, o para acordar lo pertinente a satisfacer un donativo pedido por el rey, según los testimonios que tenenos a la vista. En r686 vemos a don Domingo de Terán acometer un negocio típico de gobiemo, cual es la fundación de un pueblo de españoles, el de Nra. Sra. de Guadalıpe y Santo Tomás de Paredes, que se llamaría al cabo Nra. Sra. de Guadalupe de Frailes. Dentro de estas mismas funciones entran el repartimiento de indios para el beneficio de las minas, el nombramiento de justicias de sus pueblos, la visita de éstos y la aprobación de las elecciones de ayt1ntamientos de españoles que veremos más adelante.

\section{FuANZAS y RESIDENCIA}

Además del pago del imptuesto de la media anata que debía efectuar el alcalde mayor al hacer la obligada presentación de su título en las Cajas Reales de la gohernación a que correspondiese su empleo, había de dar en ellas fianzas de las condiciones requeridas por el derecho indiano por razón de los caudales que había de manejar durante su mandato tocante a bienes de difuntos, a penas de cámara y a las medias anatas que causasen los nombramientos de tenientes que había de hacer.

Fuera de esto, estaba preceptuado que al tomar posesión del cargo otorgase nuevas fianzas a satisfacción de las personas o cabildo ante quienes aquella ceremonia tuviese lugar, para asegurar su sometimiento al juicio de residencia que había de dar al término de su período de gobierno, y a sus resultas. Los fiadores nombrados venían a garantizar la satisfacción de cualquier condenación que se imptusiese al residenciado, y en particular tratándose del manejo de los propios y derechos del común, caso que los hubiese en los pueblos de españoles, y de los bienes de cominidad en los indios. Siendo confusa e insegura la tal toma de posesión, no siempre se acordaban tales segundas fianzas, por lo que el juez de la 
residencia, llegado el momento de ésta, reclamaba su presentación al dar principio el juicio, como ocurrió en el de don Francisco Cuervo Valdés. 34

E1 juicio de residencia del alcalde mayor corría a cargo, casi invariablemente, de su sucesor; por eso al alcalde mayor se entregaba, junto con sus títulos, la comisión para residenciar a su antecesor con sus tenientes y ministros en término de treinta días, admitiendo demandas públicas y poniendo los autos en estado de sentencia, en cuyo momento los remitiría al gobernador de Nueva Vizcaya - o al gobernador-presidente de Guadalajara en el caso de Culiacán, o al virrey en el conocido de Sinaloa- que era quien, previo dictamen de letrado, pronunciaba dicha sentencia. Cuando la alcaldía de Sinaloa se hizo vitalicia, se dispuso que a sus titulares se les residenciase cada cinco años, según consta en el juicio de Rezábal, en I7I8, instruido no por su sucesor, claro está, sino por un letrado nombrado a este efecto por la audiencia de Guadalajara, que astime con este motivo una facultad que hasta entonces habían ejercitado los gobernadores de Durango.

Varios autos de residencia de distintos justicias se custodian en el Archivo General de Indias, no viniendo, en principio, al Consejo, sino cuando en ellos se había promovido algún cargo muy importante, o cuando se había st1scitado grave polémica con motivo de tal juicio. De ordinario, la residencia de los alcaldes quedaba en los archivos de Durango, Guadalajara o México, pero en Sevilla se enctentran originales o testimoniados los juicios de residencia de Cuervo, alcalde mayor de Sonora; de Terán y de Rezábal, que lo fueron de Sinaloa; y de Iglesias, que tenía la vara de Ostimuri. De muchos otros que ejercieron su empleo en estas jurisdicciones, o en las otras meridionales, sabemos igualmente se les tomó la correspondiente residencia porque consta la presencia de los autos procedidos de ellas en el Archivo de gobernación de Durango.

34 Escribanía $400 \mathrm{C}$, pieza I, $3^{8 \mathrm{v} .-39 .}$ 
El procedimiento de la residencia era el habitual en Indias. El juez hacía público un edicto en que anunciaba quedar abierto el juicio y aseguraba la protección real a cualquiera que tuviese que hacer alguna demanda contra los residenciados. Seguidamente: formaba el interrogatorio con que se había de proceder a examinaí cierto número de testigos en pesquisa secreta; y practicaba algunas diligencias para establecer la lista de los ministros nom. brados por el alcalde mayor y que se comprendían con él en el mismo juicio, y para reconocer el archivo de la alealdía con objeto de apreciar si se había administrado correcta justicia. Igualmente, hacía mostrar sus títulos al residenciado por ver si en ellos constaba el pago de las ya aludidas fianzas. Del estudio de la pesquisa secreta y de estos otros testimonios extraía el juez los cargos que formulaba al alcalde $y$ sus subordinados.

Las preguntas de la pesquisa son casi de ritual y aparecen con notable repetición. Por ejemplo, 35 veamos las doce con que se investiga el comportamiento de Cuervo Valdés, en extracto: I) Si conocen los testigos a Cuervo y los ministros por él nombrados: 2) si han administrado recta justicia ; 3) si han admitido dádivas o tenido tiendas con daño de los vecinos; 4) si han estado amancebados o permitido que otros lo estén; 5) si han visitado la jurisdicción y si en la visita han llevado derechos; 6) si saliendo a rondar han hecho fuerza a alguna mujer; 7) si han tenido o permitido juegos públicos y no han castigado a los blasfemos y juradores; 8) si se han serrido de los indios sin pagarles o permitido se les maltrate; si se han ocupado de que se les enseñe y vivan en policía y hagan sus sementeras; 9) si han hecho guardar las ordenanzas de minería o permitido que se destruyan los pilares de los pozos; Io) si han desohedecido las cédulas y provisiones de S. M. y los autos y mandamientos de los gobernadores, y si los escribanos han guardado el arancel; IT) si han permitido que alguna persona levante vara de la real justicia sin licencia de quien la deba dar, o que el juez eclesiástico usurpe la jurisdicción real:

35 Escribanía 400 C, pieza I, 5-6. 
I2) si han tenido libro y nombrado depositario para las penas de cámara y los abintestatos, asegurado los bienes y guardado la forma de derecho. La décimotercera pregunta exhorta a los testigos a decir todo lo que supieren "de público y notorio, pública voz y fama" sobre la conducta cle los residenciados.

No es difícil advertir que buena parte de estas cuestiones indagan simplemente la obediencia del justicia a los preceptos que se le hicieron en el título. Indudablemente los autos de residencia son una pieza histórica de primera fuerza, como es opinión común entre los anericanistas, por lo que revelan de los hechos investigados y de la mentalidad con que el gobierno español los cela y los aborda. A riesgo de pecar de premiosos, anotaremos sin embargo algunos puntos constantes en el interrogatorio dispuesto por Quirós para la residencia de st1 antecesor en el gobierno de Sinaloa don Domingo Terán, en los que se muestra la importancia de la responsabilidad militar de este cargo.

Quitados los similares a los de Cuervo, son dignos de recogerse los siguientes puntos : 3) si el gobernador ha tenido trato $\mathrm{y}$ contrato con los soldados de su presidio obligándoles a traspasarle sus sueldos;4) si tuvo siempre llenas las plazas de dotación del presidio; 5) si los soldados han estado a punto y se han tenido cuerpo de gtiardia, centinelas, postas, etc.; 6) si ha consentido juegos o rifas de los soldados; 7) si ha agraviado a los gentiles o procurado su conversión y tratado bien a los cristianos; I4) si ha consentido se hagan iglesias nuevas o fabriquen casas fuertes sin debida licencia; I 5) si ha consentido se pida limosna de obras pías o fundaciones sin debida licencia, o que se publiquen bulas o indulgencias $\sin$ reconocimiento del obispo de este reino; I6) si ha descuidado los puertos de la costa o las fronteras de enemigos, o no acudió con puntualidad al socorro, y si por esto hubo daños; I7) si ha dejado de visitar anualmente los pueblos de su jurisdicción y atendió al gobierno de los naturales o les hizo violencias y repartimientos que turbaran la paz que se pretende; I8) si ha 
terido alguaciles y ministros de justicia mulatos o coyotes, o consentido que alguien alce vara de justicia sin licencia debida. $3^{6}$

A mayor abundaniento, esta pesquisa sobre Terán se dobla con otra especialnente consagrada a purificar su proceder respecto de los indios: si los hizo trabajar sin paga, si los visitó, si les hizo repartimientos obligádndoles a servir con maices, gallinas, etc., si se ha procurado el respeto de los misioneros; si se dispusieron casas, sementeras, arancel de los artículos ordinarios de comercio, etc. 37

Volvamos a la formulación de los cargos que ya dejamos apuntada. Después de lo cual entraba en actividad el residenciado procediendo a sindicarse de los que se le imputasen, recurriendo para ello a la presentación de pruebas documentales y testificales, solicitando del juez le proporcionase aquéllas haciéndolas copiar del archivo de la alcaldía, las agregase a los antos del juicio, y pidiendo además se le recibiese información de testigos sobre el interrogatorio que tenía derecho a proponer. De suerte que el residenciado llevaba adelante por estos medios su propia defensa. Ya a la vista de los cargos y descargos, y antes de que prescribiese el plazo de treinta días concedidos por la ley, correspondía al juez dictar auto de remisión al gobernador presidente o virrey que, como se ha dicho, eran quienes debían pronunciar la sentencia. No obstante lo cual no es extraño hallar que el juez daba su veredicto: así lo hizo Quirós en el caso de Terán, en Guadalupe, 2 de julio de I689, $3^{8}$ sólo para que el virrey Galve, con dictamen del fiscal don Benito de Novoa Salgado, lo antulase y pronunciase la sentencia definitiva en México, 29 de diciembre de aquel año. 39

Por cuerda separada, esto es, en expediente aparte, se iban sustanciando los autos dimanados de las demandas públicas que los particulares tenían derecho a poner al residenciado. A veces no había tales demandas; en otros casos, versaban lógicamente sobre

36 Escribanía 390 A, 6r.-9v.
37 Ibid., 53v.-55.
38 Ibid., 74r.-75.
39 Ibid., I52-I53.


daños y perjuicios causados a algún minero por no darle la competente dotación de indios de sello para la explotación de la mina o de la hacienda de sacar plata; o bien de daños a un comerciante obligado a residir en un determinado lugar por el alcalde mayor, y así otras. También sobre estas demandas, con las correspondientes defensas por parte del acusado, daba sentencia la autoridad oportuma.

Digamos, por último, que lá amplitud del juicio de residencia dependía en mucho del juez que lo sustanciase, y ello se advierte de manera especialmente clara, en el hecho de que siendo casi todas las alcaldías costeras parte de la gobernación de Nueva Vizcaya, sólo en contadas ocasiones se hicieron extensivos a ellas los edictos de las residencias de los gobernadores de Durango.

\section{Tratos y Contratos de los alcaldes mayores}

Forzoso es aquí hacer este inciso, por la importancia del tema para la mejor comprensión del carácter de los alcaldes mayores. Que comerciaban, nadie lo duda, y no sólo ellos, sino los mismos gobernadores de Nueva Vizcaya, revestidos de mucha mayor autoridad. E1 hecho es tan patente que, en algunas ocasiones, al verse enfrentados a esta acusación, replican intentando demostrar que en ellos el comerciar no es delito. En la práctica, la audiencia condenó siempre este trato mercantil de los justicias por estar condenado por las leyes; los virreyes, en cambio, no siempre fueron de este parecer. En la "Relación del estado en que dejó el gobierno de Nueva España el Excmo. Sr. don Rodrigo Pacheco y Osorio, marqués de Cerralbo", $4^{\circ}$ asienta éste que los alcaldes mayores trataban y contrataban, y que cuando se averiguaba así en las residencias eran castigados, "pero es costante que lo hacen todos, y que no haciéndolo es imposible que se sustente el alcalde mayor, porque los salarios son casi todos desde cien pesos hasta trescientos o cua-

40 Fechada en México, I7 marzo I636. Consúltese en Vázquez Espinosa, Antonio: Descripción de la Nucva España en el siglo XVII, publicada por Mariano Cuevas. México, Ed. Patria, 1944. Apéndice IV, págs. 231-232. 
trocientos... Forzoso parece o crecer los salarios o cerrar los ojos..."; en último término, a los que en tales negocios no atropellaban la justicia se sentía Cerralbo inclinado a tenerles una "disinnulación piadosa".

El caso es, pues, que los alcaldes mayores traficaban en toda clase de mercaderías, como lo hacian por persona interpuesta algunos gobernadores de Nueva Vizcaya. Y aún es de sospechar con bastante seguridad en ciertos casos que el gobernador convertía a los alcaldes en agentes de su negociación. En una ocasión se dice en la audiencia de Guadalajara que los gobernadores se oponen o dificultan la implantación del impuesto de alcabalas en Nueva Vizcaya porque no entraban en la provincia más mercancías que las suyas: "juzgo - escribe el fiscal don Pedro de Barreda- que no hay más impedimento que ser casi toda la ropa que entra en aquel reino del gobernador de él". 4 En I68I, Iglesias, alcalde mayor de Ostimuri, confiesa connerciar mercancías de Juan García Valdés, mercader que encubre los negocios del gobernador Estrada, y aum hace sospechar que se decretó contra él la visita de Cuervo porque no procuraba saldar la deuda contráda en los plazos previstos. 42 Esto dio pie al fiscal don Pedro Barreda para pedir crudanente se ordenase al gobernador de Nueva Vizcaya pusiese en las jurisdicciones alcaldes para administrar justicia y no mercaderes para atender a sus ventas. De hecho, el mismo fiscal podía advertir que Cuervo, actuando como visitador, depuso efectivamente a Iglesias de su cargo, pero "omitió inquirir sobre el trato y contrato ta:1 prohibido a vnestros alcaldes mayores, siendo así que no pudo ignorar dicho trato, pues le embargó dos tiendas, libros de cuentas y diferentes ditas". 43

Conviene saber que al propio Cuervo se le puso cargo en juicio de residencia por haber tenido tres tiendas: una en el real de San Juan Bautista, servida por don Feliciano Bernabé Moreno;

4 I Barreda a S. M., núm. Io. Guadalajara, i 8 diciembre 1682. Guadalajara, I's.

42 Escribanía too A, pieza I, fols. I-2V.

43 Pedimento fiscal de 3 marzo I682. Ibid., 3, 40I-402, 
otra, en el real de Nacosari, al cuidado de Agustín de Mesa, y la tercera en el real de San Miguel, atendida por Agustín de Moli11a. 4t Nada más valioso para nosotros que la defensa presentada por hombre tan inteligente como Cuervo, y que sirve para todos los casos similares: declara Cuervo - que no niega los hechos relatados en la acusación- que necesitaba las mercancías porque "en esta tierra no corre moneda" y sólo mediante el trueque de unas mercancías por otras o por el trabajo de los indios se puede olstener lo necesario; además, no percibiendo un alcalde en la práctica ninguna retribución, y no pudiendo los jueces pedir préstamos, sólo puede mantenerse un justicia dedicándose a alguna negociación. Y tanto más, cuanto es costante en la provincia que los alcaldes mayores habían de tener de qué echar mano para los grandes gastos que se ofrecían en muchas ocasiones de guerra, y por ello, "no debe escrupulizarse tan apretadamente dicho trato". Por eso entraban los alcaldes cargados de paño, sayal y campeche y otros géneros, para poder comprar lo necesario para el sustento y pagar a los indios. $45 \mathrm{El} \mathrm{juez} \mathrm{de} \mathrm{residencia} \mathrm{de} \mathrm{Cuervo} \mathrm{-} \mathrm{su} \mathrm{sucesor} \mathrm{en} \mathrm{la}$ alcaldía- y el gobernador de Nueva Vizcaya dieron naturalmente por buenas estas explicaciones.

La cosa era tan sabida y tan normal que el almirante Atondo, a quien el virrey dio la alcaldia de Sinaloa, tenía su propia tienda para vender a los obreros que trabajaban en la construcción de naves para ir a la conquista de California. $4^{6}$ En 1689 se halló que la casa de Terán, antiguo alcalde mayor de Sinaloa, en el real de Guadalupe tenía tienda y trastienda. 47 Por último, cuando en I699 se hizo cargo al gobernador de Nueva Vizcaya, Castillo, de haber tenido comercio, alegó su albacea —que había sido su testaferro en el negocio- que esto no había sido en perjuicio de nadie, sino en beneficio de muchos pobres labradores que hallaron socorro y

44 Guadalajara, I4 octubre r684. Escribania 400 C, pieza I, fols. 46-49v.

45 Respuesta de Cuervo en I9 octubre 1684 . Ibid., 60-67.

46 Declaración de Felipe Bermejo de la Carrera en Durango, I I marzo i681, con carta de Estrada a S. M., de 15. abril 1681. Guadalajara, 29.

47 Auto de embargo en Escribanía 390 A, cuaderno 2.0 
avío para sus haciendas, en fomento de la minería y en habilitación de los soldados, a los que surtió de armas, caballos, ropas etc. 40 Esto da idea de la variedad de las operaciones mercantiles de un gobernador.

Manteníase aquí la tesis de que lo delictivo no era el tener tiendas, sino el que ello fuese en per-juicio de los gobernados, no ya porque fuese motivo que forzase la vara de la justicia, sino porque les reportase perjuicios económicos. De esto es de lo que acusaba Luis de Morales a Cuervo, 49 diciendo que el alcalcle había vendido sus mercancías a los deudores de Morales, diciendoles que 110 pagasen a éste. En otra ocasión se acusó y condenó a un gobernador de Nueva Vizcaya por haberse alzado con el monopolio del abasto de carnes de Parral, poniendo arbitrariamente precio al ganado que compraba. Daños eran estos muy posibles y aun ciertos, pero difíciles de evitar cuando los cargos estaban mal o nada retribuídos y tenían acceso a ellos hombres dedicados de siempre al comercio.

\section{VISITAS Y VISITADORES}

De vez en cuándo aparecía en las alcaldías costeras pertenecientes a Nueva Vizcaya un visitador con facultades para investigar la actuación de los alcaldes mayores en ejercicio, el estado de las provincias y el modo con que se administraba justicia. Tal visita la decretaba el gobernador, comisionando normalmente a un mismo visitador para que reconociese varias alcaldías. Lo normal, segín hemos hallado a mediados del XVII, es que se nombre u1n visitador para Sonora, Ostinuri y Sinaloa y otro para las provincias meridionales. Es curiosa la constancia de Sinaloa en la visita, tal vez como constancia que los gobernadores hacen de no renunciar a sus derechos, y así aparecen las provincias de Sonora y Sinaloa en el título de visitador de don Francisco Alvarez de la

48 Escribanía 390 B, cuaderno I. , fol. 298.

49 Escribanía 400 C, pieza 3, fols. I-7. 
Bandera, en Parral, 5 de junio de I6I6; o bien se le da a don Carlos Gago de Mendoza y Sotomayor de visitador "de la provincia de Sinaloa y real de Sonora", en Parral, 6 de noviembre de I668. 50

$\mathrm{Al}$ parecer, el nombramiento de visitadores por los gobernadores se había implantado ya en el XVI, porque a principios del siglo siguiente declara Urdiñola ${ }^{51}$ que el gobernador de Durango podía a veces enviar jueces contra los alcaldes mayores de su jurisdicción, aunque esto sólo se hacía cuando alguna parte pedía contra ellos por vía de querella o capítulos. La justificación, sin embargo, más apropiada del nombramiento de visitadores de Sonora o Chiametla radica en el hecho de que, después de Urdiñola ( I603) y Alvear ( 1617 ), ningún gobernador de Nueva Vizcaya pasó la sierra para visitar aquella parte de los territorios de su mando. El gobernador se excusa de esta obligación propia de su empleo, haciendo presente la necesidad de su asistencia a las siempre amenazadas fronteras orientales de Nueva Vizcaya, y da al visitador facultades de que ordinariamente carecen los alcaldes mayores, como son la de suspender de sus empleos a éstos y la de conceder mercedes de tierras, asientos para haciendas de minas y casas, y como dice el gobernador Estrada en el título de visitador de Cuervo, "ha de poder hacer el dicho general don Francisco Cuervo de Valdés todo lo que yo pudiera siendo presente sin reservar cosa alguna".

He aquí ${ }^{2}$ el citado título de visitador de Sonora y Ostimuri dado a Cuervo en Parral, 6 de febrero de I68r, seguido de la facultad de mercedar tierras y del poder general otorgados en 6 de junio de mismo año.

Intitulación

El general D. Bartolomé de Estrada Ramírez, caballero de la Orden de Santiago, gobernador y capitán general de la Nueva Vizcaya por rey nuestro señor, etc. Por

5o Escribanía 390 A, I, fols. 34-35 y I 24-1 25v.

5 I Urdiñola a S. M. Durango I 5 abril I610. Guadalajara, 28.

52 Escribanía 400 A, pieza I, fols. Ig0-IgI y Igrv.-I92V. 
cuanto para cumplir con lo que S. M. que Dios guarde tiene mandado por diversas cédulas es necesario hacer la visita de las provincias de Sonora, San Juan Bautista, Real de San Migutel Arcángel y Real de Minas de San Ildefonso de Ostimuri, sus distritos y jurisdicciones y dentás reales de minas que estuviesen en ellas, haciendas de sacar plata, $y$ de ganados mayores y demás poblaciones y ranchos y estancias, y por ser preciso el que asista en estas fronteras a otras cosas de mayor consecuencia al servicio de S. M. y a la defensa de este reino por las invasiones de los indios rebeldes a su real corona y respecto de 1 o poder ir personalmente por las razones referidas conviene nombrar persona de toda satisfacción y autoridad y partes que represente la mía con el mismo poder y mando que yo tengo y porque las referidas y otras muchas de calidad, experiencia y suficiencia en las cosas políticas y militares concurren en la del capitán don Francisco Cuervo de Valdés residente en la dicha provincia de Sonora y atendiendo a ellas y porque espero asistirá con toda vigilancia y cuidado a todo lo que se ofreciere del servicio de S. M., bien y alivio de sus vasallos, $\epsilon$ su real nombre le elijo y nombro por tal juez y visitador general de la dicha proviricia de Sonora, San Juan Bautista, Real de minas de San Miguel Arcángel y Real de Minas de San Ildefonso de Ostimuri, sus distritos y'jurisdicciones y demás reales de minas que en ellas hubiere, pueblos, ha- 
Facultad judicial

Vara de justicia

Nombramiento de dependientes de la visita

Prisiones y embargos

Reconocimiento de mercedes y hierros

Trato de los indios ciendas de sacar plata y de ganados mayores, labores, ranchos y estancias, para que como tal pueda conocer y ; conozca de todas las causas, casos y cosas que conforme a derecho se requieren, fulminando las que fueren necesarias de oficio de la real justicia y de pedimento de partes, oyéndolas y administrándolas con toda igualdad, sustanciándolas y poniéndolas en estado de sentencia y citadas las partes después de su conclusión las pueda determinar y determine conforme hallare por derecho, que para todo lo anexo y dependiente y limpiar las dichas jurisdicciones de gente de mal vivir $y$ traer insignia de tal visitador general de dicha provincia y jurisdicciones le doy poder y facultad según la tengo de S. M., y para que nombre alguacil mayor y los ministros necesarios excepto escribano, que no lo habiendo público o real actuará ante sí como juez receptor con testigos de asistencia, y conviniendo hacer prisiones las hará, y embargos de bienes poniéndolos en depósito en personas seguras, y compelerá a todas y cualquiera personas a que presenten los títulos, mercedes $y$ recaudos en cuya virtud poseen los sitios, tierras y aguas de que gozan y los hierros de sus ganados si están conformes a derecho, dándome cuenta de ello, y por lo que toca a los naturales, remediará los fraudes que hubiere en esta razón reconociendo si son bien tratados, y castigará severamente a quien les hubiere hecho agravio y si asisten a sus pueblos y doctrinas a la enseñanza de 
Pesquisa contra los justicias

Suspensión de alcaldes mayores $y$ otros ministros

Visita de archivos

Cláusula penal nuestra santa fe católica o si violentados por los alcaldes mayores u otras personas, reconociendo si los dichos alcaldes mayores han administrado justicia con igualdad a las partes o en el repartimiento de los indi.os han observado igualdad y seguido las reales ordenanzas procediendo contra los dichos alcaldes mayores y justicias, sus tenientes y ministros de la dicha provincia, reales de minas y jurisdicciones, las cuales causas fulminará y stustanciará y conclusas citadas las partes me las remitirá para su determinación, dándome cuenta de todo con los dichos autos y causas breve y sumariamente para proveer lo que conviniere admitiendo las demandas y querellas de las partes siendo justas y a derecho conformes, y siendo necesario y conviniendo suspender a cualquiera de los dichos alcaldes mayores $u$ otros ministros de la dicha provincia, reales de minas y su jurisdicción, lo hará dándome cuenta de ella para proveer el remedio conveniente, que para todo y reconocer los papeles de los archivos que hubiere y todo to demás anexo a la dicha visita le doy esta comisión según y como la tengo de S. M., y mando a los dichos alcaldes mayores y justicias de la dicha provincia, reales de minas y sus jurisdicciones y demás vecinos estantes y habitantes en ellas le hayan, tengan y respeten por tal juez visitador general al dicho capitán don Francisco, Cuervo de Valdés y le reciban al uso y ejercicio de ella, pena de mil pesos en reales que aplico por tercias partes real cá- 
Ejercicio inmediato

mara de S. M., gastos de justicia y, aderezo de casas reales de este real en que desde lucgo les doy por condenados, además que desde luego, le doy por recibido al uso y ejercicio de dicha visita, y todos cumplan sus órdenes y mandatos so las penas que les impusiere que ejecutará en los inobedientes, para 1c cual mandé despachar el presente firmado de mi mano, sellado con el sello de mis armas y refrendado del infrascrito escribano de S. M., quien lo asentará en el libro de gobierno. Dado en el real y minas de San José del Parral en 6 días del mes de febrero de I68 I años. Don Bartolomé de Estrada. Por mandato del Sr. Gobernador General, Miguel de Aranda, escribano real. Asentado.

Intitulación

El general don Bartolomé de Estrada Ramírez, caballero del orden de Santiago, gobernador y capitán general de este reino y provincias de la Nueva Vizcaya por S. M. Motivación Por cuanto por hallarme ocupado en causas que necesitan mi asistencia personal en este real y sus fronteras para la paz y quietud de este reino por las invasiones que al presente tiene de los indios enemigos rebelados contra la real corona he cometido la visita general de la provincia de Sonora y real de minas de San Ildefonso de Ostimuri, sus distritos y jurisdicciones, al general don Francisco Cuervo de Valdés como persona en quien concurren las partes y calidades que se requieren, cuyo título le mandé despachar en este dicho real a los 6 días de febrero pa- 
Facultad para mercedar tierras y aguas.

Poder general dado al visitador sado de este presente año y en él no le di facultad para que pudiera hacer mercedes de tierras, aguas y sitios para ganados mayores y menores, caso muy necesario y concerniente a la dicha visita, atento a lo cual por el presente en nombre de S. M. y según que ptredo le doy poderes y factltad amplia cuanto de derecho se requiere y es necesaria al dicho general Francisco Cuervo de Valdés para que como tal visitador pueda hacer $y$ haga a cualesquiera vasallos de S. M. mercedes de tierras, sitios de ganados mayores y menores, caballerías de tierras y sacas de aguas, asientos para haciendas de minas, casas y otras cosas con calidad que los suso. aichos tengan obligación de presentar dichas mercedes en este tribunal de gobierno para su confirmación y para ello despachará mandamientos acordados recibiendo informaciones para su justificación de tal manera que así en esto como en todo lo demás que tocare y fuere concerniente a la visita de dicha provincia de Sonora y real de San Ildefonso de Ostimuri ha de poder hacer el dicho General don Francisco Cuervo de Valdés todo lo que yo pudiera siendo presente sin reservar cosa alguna porque tengo bastantes experiencias de su proceder y que me descargará la conciencia, y mando se le entregue esta comisión para que con el dicho título proceda a lo que es de su cargo como tal visitador, para lo cual mandé despachar la presente firmada de mi mano, sellada con el sello de mis armas y refrendada del in- 
frascrito escribano de S. M. que li asentará en los libros de gobierno. Dada en real y minas de San José del Parral en 6 días del mes de junio de I68I años. Don Bernabé de Estrada. Por mandato del Sr. Gobernador y Capitán General, Miguel de Aranda, escribano real. Asentado.

Aquí como en otros casos se observará que la función del visitador podía ir unida a la de alcalde mayor de una de las jurisdicciones sujetas a la visita. En otras ocasiones, no siendo el visitador uno de los alcaldes mayores, se daba a aquél y no a éstos el carácter de teniente de gobernador y capitán general de las provincias a visitar, y así lo hizo Oca con el general Juan de San Martín y Vértiz, nombrado visitador de las jurisdicciones de Chiametla, Copala, Maloya y sus distritos. $53 \mathrm{El}$ título de San Martín ofrece otras particularidades, como es la de facultarle para reconocer los títulos de encomiendas junto con los de tierras y aguas, y para confirmar mercedes; la de autorizarle a nombrar ministros para la guarda de su persona "por ser la tierra de guerra y haber naciones alzadas y rebeldes"; y la de señalarle salario de diez pesos diarios "por cuenta de culpados, y no de otra hacienda".

Competencias de la AUdiencia

CON EL GOBERNADOR

Se hace preciso entrar a analizar los choques jurisdiccionales habidos entre las principales autoridades de Nueva España en orden a la provisión de las alcaldías costeras objeto de nuestro estudio, y a su gobierno. Conviene saber, que todas las diatribas se refieren precisamente a las provincias correspondientes a Nueva Vizcaya, porque Culiacán no suscitó ninguna ingerencia del virrey, único que podría aquí competir con la audiencia. En cambio, en

53 Nombrado en ${ }_{14}$ enero I678. Escribanía 397 A, pieza I, fols. ro4-106v. 
las alcaldías dichas, virrey, audiencia y gobernador entran frecuentemente en colisión, y el mismo rey, según se ha indicado más arriba, entrará a ejercer su autoridad soberana para complicar más la situación.

Empezamos considerando el enfrentamiento de Nueva Galicia y Nueva Vizcaya porque su motivación es más puramente institucional, mientras que las restantes polémicas obedecen ya a casos históricos concretos. Hablando de las provisiones de enpleos se ha dicho cómo la audiencia repugnó los nombramientos hechos por el gobernador sin facultad jurídica explícita para ello. Resuelto el caso con la fórmula de que se guardase la costumbre - sancionando favorablemente, por tanto, la actuación de los gobernadores- planteó la audiencia otros de sumo interés. Futeron estos los referentes al nombramiento de visitadores, a los juicios de residencia de los alcaldes, y a las apelaciones de las sentencias dadas por éstos.

Tocante a las visitas fue el depuesto alcalde de Ostimuri don Francisco de Iglesias quien en su actusación contra Cuervo asentó que tales visitas estaban prohibidas. 54 Claro que a su vez el gobernador don Bartolomé de Estrada manifestó 55 haher procedido a nombrar visitador como lo habían hecho sus antecesores propietarios e interinos: efectivamente, el escribano de gobierno podía certificar que Valdés, Dávila Pacheco, Gorráez, Sierra y García de Salcedo habían despachado títulos de visitador. Sabemos que también antes de Valdés se habían decretado visitas, como lo manifestó el mismo Urdiñola. La audiencia, sin embargo. se hacía en I68 i ignorante de estos antecedentes y en real provisión de 29 de agosto $5^{6}$ inquiere con qué facultad nombró Estrada a Cuervo, estando dispuesto por reales cédulas que las visitas las hiciese el gohernador personalmente y sin llevar derechos, ni cometerlas a otros. Las cédulas a que la audiencia alude son de 28

54 Guadalajara, 8 agosto I68ז. Escribaria 400 A, pieza I, fols, I-2V.

55 Escribanía 400 A, pieza 3, fols. 400-402.

56 Ibid, pieza I, fols. I5-I9v. 
de noviembre de I $55^{\circ}$ y II de junio de I $55^{2}$, y sin duda su espíritu era correcto, pero no sería menos cierto que no se adecuaban a la realidad de la inmensa extensión territorial de una gobernación como Nueva Vizcaya, difícil de transitar y hostilizada además constantemente. Sin embargo, la audiencia las aplicó para condenar el nombramiento de Cuervo en el primer cargo de la sentencia de vista contra éste, en I 689. ${ }^{57} \mathrm{El}$ defensor, al solicitar la revisión de dicha sentencia hubo de atenerse al caso estricto de Cuervo, alegando que, aunque el gobernador de Nueva Vizcaya tuviese prohibido el nombrar visitadores, Cuervo to había sido, por cuanto aquellas cédulas carecían de clátsula irritante, que anulase el título ilegalmente expedido por el gobernador. El nombramiento de Cuervo sería, en todo caso, ilegal, pero válido. $5^{8}$ Por esta $u$ otra razón, ni la audiencia, ni posteriormente el Consejo de Indias, volvieron a tocar este asunto, y los gobernadores de Nueva Vizcaya continuaron decretando visitas en el siglo siguiente. Vinculado a este punto está el de la facultad de Cuervo para destituir a Iglesias, impidiendo así el ejercicio de la jurisdicción ordinaria, "lo cual no se concede ni a las reales audiencias". 59 Este problema está resuelto si se da por bueno el nombramiento del visitador, con todo lo que comprenden sus títulos.

Quejábase ya la audiencia a principios del XVII de que las residencias de los alcaldes mayores las viera y determinase el mismo gobernador, pero Urdiñola aseguraba que siempre se había hecho así y que sólo en casos de apelación iban los autos a Guadalajara. 60 En este estado se mantenían las cosas en I630, cuando el presidente Núñez Morquecho escribía al rey que ninguna residencia de Nueva Vizcaya venía a la audiencia, lo que era contrario a lo legislado, y que en las comisiones despachadas por el Consejo para residenciar a los gobernadores no se comprendía a los

\footnotetext{
57 I4 mayo r689. Escribania 400 B, pieza I, fols. 298-308.

58 Pedimento de 23 agosto I 689. Ibid., fols. 334-36r. $226 \mathrm{v}$.

59 Respuesta fiscal de 9 septiembre I682. Escribanía 400 A, pieza I, fols, 224-

60 Urdiñola a S. M., I5 abril I610. Guadalajara, 28.
} 
juteces y alcaldes nombrados por ellos. A la vista de estas noticias dispuso el Consejo confusamente que se viesen las residencias de los alcaldes cuando se le tomase al gobernador, ${ }^{6 r}$ pero continutaron sin enviarse a Guadalajara, de suerte que hubo la atudiencia de ordenar por real provisión de 28 de febrero de 1674 a García de Salcedo que "al tiempo que se tomaren las residencias a él y a los demás que le sucedieren en aquel cargo, se tomen también a los alcaldes mayores que hubieren nombrado y nombraren, y que éstas se cometan a los que sucedieren en aquellos oficios, y que determinadas las remitan a esa audiencia para que en ella se reconozca si se han tomado como se debe y si se cumple con ella la buena administración de justicia”. Así venía dispuesto en real cédula de I I de febrero de I673, dada a petición del fiscal Haro. Se ve claramente su inadecuación al sistema de alcaldes bienales o trienales, cuando los gobernadores ejercían su cargo cinco y más años. La audiencia supone que cada gobernador entrante nombra nuevos alcaldes para todo su quinquenio. El hecho es que en I679 nada de lo dispuesto se había cumplido y la audiencia ordenó a don Bartolomé de Estrada enviar en plazo de cuatro meses, pena de dos mil pesos, todas las residencias de los alcaldes de la gobernación desde que se despachó la real cédula, y además, todas las de los alcaldes provistos por Rebollar, que murió en el ejerccio del cargo, y por Sierra y Agramont, que fueron interinos. ${ }^{6 z}$ Estrada se limitó a disponer que se tuvieran preparadas las de los nombrados por estos tres y por él mismo, para que cuando se le tomase a ellos la residencia pudieran reconocerlas sus jueces, ${ }^{63}$ y nada de ello debió de llevarse a cabo. La audiencia no nombró juez de residencia en Nueva Vizcaya hasta que huho de tomársela a Rezábal, gobernador vitalicio de Sinaloa, ya en el XVIII. 64

6 I Resolución de 9 agosto 1631 . Guadalajara, 9.

62 Real provisión de 29 octubre I679. Escribanía 400 A, I, r60-164.

63 Auto de Estrada, 24 febreto I680. Ibid., 164V.-I65, y testimonio con carta de clon Pedro de Barreda a S. M., mún. ro. Guadalajara, is diciembre r682. Guadalajara, I 8 .

$6+$ Escribanía 39 I C, pieza I. 
En cuanto a las apelaciones de las sentencias impartidas por los alcaldes, que teóricamente correspondían a la audiencia, ya es sabido que los gobernadores las avocaban a sí alegando las distancias que mediaban hasta Guadalajara y los quebrantos que esto suponía a las partes - y evitando, en el fondo, la intervención de 1a audiencia en Nueva Vizcaya. ${ }^{65}$ Al fin y al cabo, el gobernador era juez único de lo civil y de lo criminal en toda su jurisdicción.

\section{Nueva Vizcaya contra el virrey:}

\section{LA Disputa POR Sinaloa}

El enfrentamiento del gobernador de Parral con la máxima autoridad indiana en lo puramente político tiene su origen, según se ha dicho páginas atrás, en la futerza que fue adquiriendo el capitán del presidio de Sinaloa, de nombramiento del virrey, y en la pretendida ampliación de su autoridad sobre Sonora. No se abre aquí la controversia hasta que Perea pasó a poblar esta Nueva Andalucía; hasta entonces, estando bien claro que el gobierno civil de Sinaloa correspondía al gobernador de Nueva Vizcaya, pero que el presidio estaba subordinado al virrey, por espacio de cincuenta años —dice Pérez de Ribas- ${ }^{66}$ los gobernadores habían nombrado justicia a la misma persona que el virrey designaba capitán de la milicia. Así había ocurrido con Alonso Díaz, Hurdaide y Perea. "Luego se ha variado el método, y un caballero que había sido capitán (Perea) pidió título de capitán y poblador y privilegios de una parte de Sinaloa, desde el Yaqui adelante, obligándose a sustentar veinticinco soldados de escolta. Asentó su casa en el valle de Sonora y se siguieron los inconvenientes de división y diferencias de jurisdicciones." En efecto, ya el gobernador don Luis de Valdés se había quejado - aunque sus razones no parecen muy sólidas- de que el virrey marqués de Villena le usurpaba en Sinaloa el nombramiento de los oficios de

65 Urdiñola a S. M. Durango, is de abril г6го. Guadalajara, 28.

66 Idem, 238-239. 
gobierno y guerra. ${ }^{67}$ Como Valdés no apoyaba su reclamación con prutuas de ninguna clase, el fiscal del Consejo se limitó a proponer que se pidiesen informes sobre el particular al virrey y que en interin se guardase la costumbre sin que se cansase agravio al gobernador ni se le quitase la jurisclicción que le tocase. E1 Consejo se achirió a este parecer, en 2 de mayo de I6.4. ${ }^{6}$

Las consecuencias de esta disposición nos son desconocidas. Las reclamaciones de Valdés se dirigen, al parecer, contra los títulos dados por Villena a don Luis Cestín de Cañas. La cuestión se agrió cuando en 9 de octubre de 1645 hizo el virrey conde de Salvatierra que don Juan de Peralta, que era capitán del presidio cle Sinaloa, pasase a sustituir a Perea en Nueva Andalucía, reuniendo ambas jurisdicciones; y Peralta tomć efectivanente posesión de la alcaldía de Sonora el i I de abril de 1646 . El almirante Porter Casanate sucedió a Peralta muy poco después, en todos sus cargos, y por mandamiento que tuvo de la audiencia gobernadora de 26 de agosto de i649 manclando que se guardase la costumbre y posesión en que se hallase el capitán del presidio de Sinaloa, estuvo al año siguiente visitando Sonora con su tropa, y el 29 de noviembre de 1650 impidió en la villa de San Felipe y Santiago que pasase adelante el capitán Juan Fernández de Morales, nombrado por Guajardo Fajardo alcalde mayor de Sonora, diciéndole "con severa demostración: haga Vd. lo que quisiere, que yo tomaré testimonio y claré cuenta a S. E. y en ínterin obrará el presidio". ${ }^{6}$ La polémica, sin embargo, se reducía en estos momentos al mando militar, porque Porter manifestó que permitiría la administración de justicia a Fernández de Morales, pero en cambio tenía persuadidos a los vecinos de la villa de que sólo a él tocaba el mando de las armas de las provincias. Volvióse, pues, Fernández por evitar las competencias en momento tan grave como era el de la primera sublevación de la Tarahumara. El inci-

67 Guadalajara, 28.

68 Ibid.

69 Auto de Porter. Sinaloa, 29 noviembre I650. Auto de Guajardo, 26 febrero 165 I. Guadalajara, 29. 
dente venía a sumarse a los ya provocados por Porter entorpeciendo, según Guajardo, la actividad del justicia Simón Lasso de la Vega, y que le habian movido a escribir un año antes al rey contra el nombramiento por los virreyes de los capitanes del presidio de Sinaloa, "que habiendo sido desde su fundación sujeto a este gobieno, los virreyes de la Nueva España han avocado a sí el proveerle con tácita permisión de mis antecesores, y no teniendo más jurisclicción que la del presidio, procuran ampliarla e introducirse con potestad en la provincia de Sonora, originando algunas competencias". Deseaba Guajardo que el rey aclarase a quién tocaba el gobierno de aquellas provincias. 70

Después de esto se observa que el capitán de Sinaloa actúa con frecuencia, en lo militar, en Ostimuri y Sonora, pero que en cambio otras veces hay dualidad de autoridades en la villa. E1 gobernador había hecho valer sus derechos y nombraba alcaldes mayores, tenientes de gobernador y capitán general y visitadores para Sinaloa, independientemente o no de los capitanes establecidos por el virrey. Y del mismo modo nombró alcaldes mayores con el pleno de sus facultades civiles y militares para Sonora. Dura esta fase hasta 1678 , y es el momento de más directa autoridad de Nueva Vizcaya sobre Sinaloa.

En I6.78 capitula el almirante Atondo y Antillón la conquista de California, con condición, entre otras, de tener por cinco años el gobierno político y militar de Sinaloa. A la junta de hacienda habida en México el 28 de noviembre de 1678 asistió en calidad de contador general de Tributos don Bartolomé de Estrada, electo gobernador de Nueva Vizcaya, quien se manifestó propicio a dar a Atondo el título de alcalde mayor y teniente de gobernador. El caso es que ẹl virrey dio por su cuenta estos títulos y Estrada hubo de protestar desde Parral, quejándose de que Atondo hubiese salido "tan favorecido con los despachos de la Junta general, dándole absolutamente la superintendencia de la jurisdicción que este gobierno tiene en la provincia de Sinaloa, que aunque yo la

70 Guajardo a S. M. I9 enero 1650. Ibid. 
ofrecí con el afecto que debo al servicio de S. M., y siempre se la daría al dicho almirante o persona de su devoción si ne la hubiera pedido dándole título de alcalde mayor y capitán a guerra, como lo tuvo su antecesor don Pedro Hurtado de Castilla, que también fue capitán del presidio de Sinaloa con título de V. E. como el dicho don Isidro, y no es lo mismo ofrecer una cosa que decir que la usurpen, como lo ha hecho el dicho don Isidro, que en esa ciudad yo hice lo que debía y lo que pude, que fue ofrecerla, que los despachos no se los pude dar porque no había tomado posesión de este gobierno, que es a quien toca darlos, y esperé un año por ver si me los pedía, y no habiéndolo hecho e introducídose a la jurisdicción, despaché título de alcalde mayor a otra persona, que también lo ha embarazado... Espero que V. E. se servirá de contener a este sujeto supuesto que para el fin de la conquista de las Californias no conduce el quitarle la jurisdicción que siempre ha tenido este gobierno, y más cuando yo asistiré con todo afecto a cuanto se pueda of recer". 7r

Estrada prueba después, escribiendo al rey, con certificación del escribano Aranda, $7^{2}$ que en los libros de asiento de títulos existentes en Parral consta que Mateo de Vesga, en Io de diciembre de I6:22, había expedido mandamiento a Hurdaide para que remitiese a Durango lo procedido, de penas de cámara y bienes de difuntos; y en 4 de marzo de 1626 había dado a Perea título de teniente de gobernador, capitán general, cabo y comisario y alcalde mayor. La certificación no recoge noticias de los sucesores de Vesga; debió ser don Luis de Valdés quien nombrara alcalde mayor a Pedro de Zamudio. Su sucesor, Guajardo Fajardo, despachó títulos de justicia mayor y teniente de capitán general a Diego de Alarcón Fajardo en I I de enero de i649, dándole luego comisión para residenciar a Zamudio. Dávila Pacheco hizo alcaldes mayores a Juan Coronado ( 8 de febrero de I655), don Mannel Francisco de León ( 22 de julio de I6.57) y don Juan Manuel de

7 I Estrada al virrey. 22 julio I680. Guadalajara, I38, I, 30v.-33.

72 Testimonio de autos sobre Atondo, fol. I.759. Guadalajara, 29. 
la Escalera, que era capitán del presidio y a quien nombró además teniente de capitán general (18 de noviembre de 1659). Gorráez nombró alcalde a Matías Pereyra (2 junio I66I). García de Salcedo, a don Miguel Calderón y Ojeda (7 de marzo de I67I) y a Francisco de Luque (Ig de mayo de I674). Don Lope de Sierra, a don Pedro Alfonso Hurtado de Castilla, que era capitán del presidio (27 de marzo de I677). Faltaban en Parral los libros correspondientes al gobiemo de Oca Sarmiento y al interinato de Estrada. Como los libros de Oca están en el Archivo General de Indias, sabemos hoy que nombró alcalde mayor de Sinaloa al alférez Andrés de Buelna (25 de agosto de I666).73

Narremos ahora el incidente aludido por Estrada en su carta al virrey. A fines de I679 se presentó en Sinaloa Lázaro Verdugo, nombrado alcalde mayor de Sonora y teniente de gobernador de ambas provincias. Atondo no le permitió tomar posesión de este título en la de su mando, considerando de mayor valor su propio nombramiento de gobernador político por el virrey y de acuerdo con cédulas reales. Volvió Verdugo la víspera de San Francisco Javier - es decir, el 2 de diciembre-con pretensión al parecer de ocupar puesto preminente al de Atondo en la función eclesiástica. Acudió Atondo al obispo Escañuela, que se hallaba de visita en la villa, y por su consejo convinieron ambos en no innovar nada. El fiscal de México, Solís Miranda, aprobó la actuación del almirante, y el virrey, por despacho de 4 de mayo de i680 le ordenó no permitiese que nadie atentase a su jurisdicción durante el quinquenio que se le había concedido por asiento. Muy poco después tenía lugar el incidente: el 3 de abril había expedido Estrada título de alcalde mayor de Sinaloa a don Gabriel Fontes de Espinosa, vecino de la villa. Recibiólo Fontes y se presentó con él el 20 de mayo ante el cabildo de Sinaloa presidido por Atondo y congregado en la casa de éste. Los capitulares quisieron dar posesión a Fontes, pero Atondo manifestó su título y tener quieta posesión del cargo, que recibió de don Pedro Hurtado, y se opuso a hacer

73 Escribanía 397 A, pieza I, fols. 57v.-59. 
entrega de él a Fontes, quien envió testimonio de lo acaecido al Parral. 74

Con noticia de ello, condenó Estrada por auto de 26 de junio el que los capitulares se hubiesen reunido en el domicilio del alnirante y ordenó que, constituyendo el cabildo en casa de alguno de ellos, recibiesen a Fontes por alcalde $y$ le entregasen la vara de justicia mayor, pena de quinientos pesos a cacla nuo de los que no lo hiciesen así. Que si Atonclo lo estorbase, le requiriesen se abstuviera, protestándole daños, inquietudes y escándalos en caso contrario. Fontes no consentiría que nadie alzase vara sino por nombramiento suyo o de quien lo pudiese dar, pero auxiliaría a Atondo en la construcción de las naves para el viaje a California. Se le encargaba además recibir información de lo actuado por el almirante como alcalde mayor. 75

A fines de setiembre, estando solo en la villa el alcalde ordinario José Romo de Vivar, presentó Fontes el mandaniento de Estrada para que se le pusiese inmediatamente en posesión. Romo convocó a cuatro vecinos y dio posesión a Fontes, pero sabiéndolo Juan Antonio de Anguis, cabo y caudillo de los presidios y teniente en lo político de don Isidro, íue a casa de Fontes y le requirió no alzase vara, pena de mil pesos. Llegados el alcalde Antonio de Gastegui y el regidor don Prudencio Tello, dieron por buena la posesión otorgada dos días antes. Pero entonces les intimó Atondo, $7^{6}$ por auto de 28 de setiembre que, en virtud del clespacho del virrey del 4 de mayo, se alsstuviesen los alcaldes y regidores de la villa cle dar posesión de justicia mayor a ninguna persona que lo pidiere, amnque presentase despachos y provisiones, hasta que él los llimase a cabildo como se había acostumbrado para dichos actos, pena de quinientos pesos a cada desobediente. De este modo prevenía el almirante lo que pudiese ocurrir mientras él acudía al pueblo de Nío para atender a la fábrica de bajeles que tenía co-

74 Testimonio de antos solre Atondo, fols. r-3v. Guadalajara, 39.

75 Ibicl., fols, $3 \mathrm{v},-5 \mathrm{v}$.

76 Ibid. fols, 8vi-no. 
menzada allí. Firmaron Gastegui y Romo la notificación de este auto, pero luego, para cumplir el mandamiento del gobernador, se dirigieron a Nío el 3 de octubre y requirieron a Atondo, ante escribano, por primera, segunda y tercera vez para que no estorbase la posesión de Fontes. Atondo replicó que se atendría a lo ordenado por el virrey el 4 de mayo, y los alcaldes se retiraron, convocando cabildo en Sinaloa el 7 de octubre para acordar la comunicación a Estrada de los sucesos, indicado que se hallaba el almirante "con la mano del gobierno de la guerra, cuyos soldados dispuestos a su orden los tenía para proseguir con fuerza al embarazo a la dicha posesión... cuya fuerza se hubiera experimentado a no haberse atravesado por medio las personas de suposición y cristiano celo que... han solicitado el medio de la paz". 77 También Fontes escribió a Estrada: "Hallamos que todos los soldados de este presidio los tenía recogidos dicho almirante, por su cabo y caudillo, a los cuales los tenían prevenidos de pólvora y! balas diciendo públicamente no había de consentir en su tiempo a mí ni a otro ningún alcalde mayor". Eran más de cuarenta los soldados, y había otros tantos hombres en el astillero de Nío a las órdenes de Atondo, que llegó a prender al regidor Tello porque se atrevió a decir que la autoridad superior de la provincia era Estrada. "El capitán Francisco de Lucenilla, que se halla en esta villa por varios accidentes de fortuna, hombre de mucho porte y de cristiano pecho", fue quien terció para que los capitulares cediesen, por evitar daños, y también él pasó sus noticias al gobernador.

Estrada dio parte de todo al virrey y a la audiencia de Guadalajara, ${ }^{8}$ reclamando se le subordinase Atondo, que estaba en su jurisdicción, y lamentando no poder acudir a Sinaloa por tener que atender a las resultas del reciente levantamiento de los indios de Nuevo México. Sin embargo, el virrey conde de Paredes, considerando que el asiento hecho con el almirante era justo, ordenó

77 Ibid., fols. Io-I $6 \mathrm{v}$.

78 Cartas de 4 y 27 noviembre I680. Ibid., fols. I9-21. 
que no se diese posesión a la persona que hubiese nombrado o nombrase el gobernador de Nueva Vizcaya. 79 Estrada acudió con todo al rey, pero el Consejo sólo pudo dictaminar, con el íiscal, que no se podía quitar a Atondo la jurisdicción política y militar que se había concedido por asiento por cinco años. ${ }^{s_{0}}$

Desptués de esto las facultades del gobernador de Nueva Vizcaya sobre Sinaloa quedaron muy mermadas. El virrey nombró a Terán de los Ríos sucesor de Atondo, con las mismas atribur ciones que había tenido éste, juzgando subsistían las mismas conveniencias en orden al descubrimiento y cristianización de Californias, y sólo en I 685 la real cédula de 22 de diciembre vino a establecer de manera firme que el mando militar de Sinaloa estaríá subordinado al gobernador del Parral, pero su provisión correspondería al virrey de una terna propuesta por aquél. Siguió dándose juntamente el gobierno político, y éste, por las razones aducidas en la céclula, vino a hacerse vitalicio. Pero la intromisión del poder real vino de todos modos a interferir en el normal desarrollo de este asunto.

Polf́mica entre aUdiencia y virrey. El real de Paredes y el motín de Sinaloa

Mientras Estrada pugnaba con el virrey por mantener su jurisclicción sobre Sinaloa, mantúvose la audiencia, al parecer, expectante. Inego, cuando los sucesores de Atondo - Terán y Quirós- obtuvieron el "pase", la audiencia puso sus reparos para salvaguardar los legítimos derechos del gobernador, reconocidos ya por ella después que en la primera mitad del siglo había estado objetándolos. Terán presentó sus títulos en Guadalajara en marzo de 1686 solicitando el pase ordinario. El fiscal Dr. don Luis Martínez Hidalgo informó que se podía conceder, "sin perjuicio de la facultad o derecho que compete a vuestro gobernador del Parral

79. Mandaniento de io diciembre 1680 . Ibicl, fols. 3ov.-31v.

So cstrada al rey, 2 abril 168 I, y respuesta fiscal de 2 agosto I682. Guarlalajara, 29 . 
cuando cesen los motivos de dicha nueva conquista de la California y su más fácil expeclición y socorro", con ctrya causa se iprobú la agregación del empleo político al militar en Atondo por real céclula de 29 de diciembre de 1679 . La audiencia otorgó el pase con las clátsulas indicadas clel fiscal, por anto de 2 de abril de 1686 . \$2

Al año siguiente acudió Quirós con icléntica pretensión. El mismo fiscal, en 9 de julio de 1687 , hizo constar que "con el motivo de haberse acostumbrado a nombrar por vuestro virey en dicha provincia alcalde malyor como se hizo con don Isidro de Atondo y Antillón con el pretexto del asiento que hizo del nuevo déscubrimiento de la California y por el tiempo sólo de dicho asiento, y después al capitán don Domingo Terán de los Ríos por tiempo de un año, cuyo paso de jurisdicción politicá y agregación de alcaldía mayor así en el dicho don Isidro de Atondo, cono en el dicho don Domingo Terán se ha hallado por V. A. por sus autos de 8 de mayo del año pasado de $6 S_{4}$ y 2 de abril del próximo pasado de 86 con la cláusula y calidad de por ahora y sin perjuicio de la jurisdicción superior de esta real audiencia y de la facultad y derecho que compete al gobernador y capitán general de la Nueva Vizcilya cuando cesen los motivos de la dicha nueva conquista de California..." ; en el caso presente podrían pasarse con los mismos términos los títulos de Quirós, pero "se debe más expresar para preocupar la perpetuidad que por este título nuevamente presentado se procura introducir sin expresa facultad de vuestra real persona, porque dicha real cédula citada - la de 22 de diciembre de I685-sólo habla de los puestos militares de los presidios para que se provean en perpetuidad, y son vuestras leyes reales prohibitivas de semejantes provisiones de puestos políticos en perpetuidad y en distrito de otra gobernación, que se halla reservada a sola vuestra real persona y sin su expresa facultad que conste no puede subsistir". Así, pues, se dio el pase a Quirós el i 2 de julio de 1687 con la misma cláusula que a Terán, ${ }^{82}$ y de toda la preo-

8i "Autos que sigue el capitán Don Manuel de Agramont... con el sargento mayor Don Diego de Quirós...", fols, 37v.-39v. Escribanía, 18 I B.

S2 Ibid., fols. 44-53. 
cupación manifestada por el fiscal dio noticia la audiencia al rey en 26 de mayo de I688, cuando se trataba ya de la polémica suscitada con el virrey con motivo de la fundación clel real de $\mathrm{Pa}$ redes, hecho al que ya aludimos al hablar de la minería en las provincias pero que ahora se hace preciso marrar aquí más por extens.o.

En el testimonio de la junta tenida en el puesto de los Alamos el 13 de octubre de $1686,8_{3}$ Terán clice que los vecinos le han representado repetidas veces "descle el asiento primero de este gobierno a la villa de Sinaloa, por parte de mi lugarteniente, vecinos, mineros y demás partícipes interesados en este descubrimiento del Cerro de Nuestra Señora de la Concepción de los Frailes" para que viniese a providenciar la planta y sitio que debe tener el real, que no está formado, sin iglesia, ni casas reales, "de más tiempo de tres años que ha que se descubrió". Además había ruídos sobre pretensión a las minas. "Y habiendo reconocido también el puesto que llaman de los Alamos, que es la parte clonde al presente residen la mayor parte de los vecinos, mineros e interesados" lo consideró poco apropiado por no ser el aguaje permanente y que podría secarse, y "habiendo corrido a la diligencia más de cincuenta leguas con asistencia de los dichos vecinos, mineros e interesados que me acompanaron para la busca y reconocimiento de la referida planta y sitio, catados todos los aguajes y no habiendo reconocido ninguno proporcionado, se halla por el mejor para la dicha fundación y real el que está sobre la ribera del río Mayo, en la medianía de los dos pueblos de Conicarit y Camoa, que dista del dicho cerro y descubrimiento cinco leguas con poca diferencia de tierra llana". Buen lugar, con dos arroyos, pastos, maderas, "y las salinas cerca a distancia de veinte leguas de este mar del Sur", donde se podrían fundar cuantas haciendas de beneficio de azogue de rueda alta quisieren, como en Potosí (Perú).

$8_{3}$ "Testimonio de los autos hechos a pedimento de Don Blas de Guzmán y Córdoba contra el general Don Domingo Terán de los Ríos...", fols. I-5v. Guadalajara, 19. 
Entonces llamó a Junta General con asistencia del Br. Francisco Sáenz de Carrizosa, cura y vicario del descubrimiento, y todos convinieron en el lugar, con el nombre de Nuestra Señora de Guadalupe y Santo Tomás de Paredes, a más de las razones dichas por éstas.

I. - - Porque es voluntad del rey que los vasallos vivan congregados y tengan iglesia.

2. ${ }^{2}$ - Porque se tiene reconocido en los reales de minas que estando distantes se evitan muchos daños, y el virrey Toledo prohibió se hiciesen sobre cerros de las minas, y Lemos, después de la sublevación de Puno, extinguió ese real y lo restauró a cuatro legrias.

3. "-Porque a esta distancia se evitan los "hucos", que de ordinario entran en las minas a hurtar los metales derribando los pilares y puentes, con lo que quedan encampanados y se imposibilitan las labores, y se derrumba la mina.

Por todo esto, "y porque se tiene la noticia de que todavía el enemigo de Etrropa infesta estos mares, sin el aviso de si ha desalojado o no y sin saber su paradero y derrota, y que será bien para que esto se mantenga en paz estén unidas las fuerzas y con los resguardos convenientes para cualquiera operación que dicho enemigo intente y conviene en todo frangente que haya unión que de tener vigías en la costa y de todo lo demás referido tengo dado cuenta al Excmo. Sr. conde de Paredes... como a la Sala de Justicia de la Corte, como al Sr. Presidente... en Guadalajara...".

"En la Junta, hecho el juramento y solemnidad acostumbrada según derecho, votaron unánimes y conformes se formase la referida planta con la advocación de Nuestra Señora de Guadalupe y Santo Tomás de Paredes para que se ejecute en ella su población en nombre del rey n. s. don Carlos II (q. D. g. muchos y felices años como la cristiandad ha menester y la monarquia necesita) por el real patronato y jurisdicción que ejerzo, sin atribuirme más que la que por derecho compete, protestando cada uno 
asistir a su función y a lo que le corresponde y fomentando en la forma referida como leales vasallos...".

A1 día siguiente - I4 de octubre de I686-bajó Terán al lugar convenido, señaló sitio para iglesia y casas reales y fue distribuyendo solares, percibiendo los correspondientes derechos. Pero once días más tarde faltaban muchos mineros y connerciantes que no habían renido aín , y dispuso acudiesen pena de 500 pesos, en plazo de cuatro días después de notificárseles esta orden, que se pregonaría en Nuestra Señora de la Concepción de Alanos el doningo 27 después de misa nayor. ${ }^{84}$ De resultas de este mandato vinieron algumos comerciantes, pero pronto empezaron a quejarse de que los que no lo hatbían obedecido hacían negocio en Frailes, mientras a ellos se les estropeaban los géneros en la nueva población donde no había casas y nada vendían. Por consiguiente, Terán hizo repetir el pregón dando sólo dos días de plazo, amenazando con quinientos pesos de multa o cien azotes a los mulatos, niestizos y coyotes que no acudiesen a Paredes, y ordenando se notificase especialmente la orden a Simón de Dudagoitia, Tomás de Peralta y Alonso Ruiz Cintado, mercaderes. ${ }^{85}$ Pero esta segunda llamada no debió tener mucho más éxito que la anterior.

E1 I I de enero de r687 quedaron designados y confirmados dos diputados elegidos para conservación del comercio: don Juan Hurtado de Mendoza y García de Ilarregui Pollerena. Y todo el comercio pidió al justicia que hiciese poner en vigor los dos autos para poblamiento del real. Terán dio ahora tres días de plazo. E1 2 I de enero piden los diputados que se ejecuten las multas en los inobedientes; los ejecutores encuentran el 24, en el puesto de la Aduana, a Diego de Amarilla dispuesto a trasladarse. Pero el 25 sacan a Blas de Guzmán dos cajas de chocolate y dos tercios dé azúcar, por valor de los quinientos pesos.

No nos es desconocido Blas de Guzmán, porque en época inme-

S+ Auto cle Terán, Paredes, 25 octubre 1686. Tbid., fols. 5v.-9.

S5 Petición de los mineros y auto de Terán, Io noviembre r686. Ibid., fols. $9 \mathrm{~V}-\mathrm{I} 3$. 
diatamente anterior a la de este episodio lo vemos figurar como uno de los capitanes de mar y tierra de la expedición de Atondo a California. En esta ocasión, se apresura a dirigirse a la audiencia - Terán había rechazado dos pedimentos suyos- en demanda de justicia. La audiencia ordenó a Terán que enviase los autos sobre la nueva población, y que restituyese la multa extraída a Guzmán, y además se le inhilió de conocer en todas las causas que afectasen a éste, que quedarían encomendadas a un alcalde ordinario de Sinaloa. Esta fue la real provisión de 2 I de febrero de 1687 para cuya ejecución se comisiona a Juan Antonio de Anguis y en su defecto a Juan del Hoyo. ${ }^{86}$ Encargóse éste, por ausencia del primero, de presentarla ante Terán, el $2 \mathrm{I}$ de marzo, y con sorpresa por su parte se halló con que éste se negó a darse por notificado de otra forma que no fuese ante sí mismo, poniendo por su mano el obedecimiento con las razones para no cumplir la real provisión, y luego conminó a Guzmán de nuevo pasase al real de Paredes, y ante su desobediencia le hizo descerrajar la puerta para sacarle multa de mil pesos en cajas de chocolate y tres tercios de azúcar que le fueron requisados.

Ante esta novedad la audiencia se precipitó a prover dos autos de 18 de abril de 687 que dan lugar a dos reales provisiones fechadas tres días más tarde. La primera es sobrecarta de la de 2 I de febrero y dispone que Terán comparezca en Guadalajara en plazo de cuarenta días después de serle notificada tal orden; multa a a cada diputado del nuevo real en doscientos pesos y reitera la voluntad de la audiencia de que se reintegre a Guzmán la multa que se le impuso. La provisión se dirige esta vez a Alonso Ruiz Cintado. El segundo auto de provisión de Guadalajara es sorprendente y da idea de que la audiencia sabía con quien se las había. Por él se ordena a Ruiz Cintado que si Terán no parte para Guadalajara a los quince días de serle notificada la anterior, lo prenda y remita arrestado. Dos días más tarde por pedimento y auto añadidos a la misma provisión, se anuló el plazo de quince días te- 
miendo que en este tiempo intentase algo Terán para evadirse de dar cuentas a la audiencia. ${ }^{8}$ Ruiz Cintado dio su obediencia a la primera provisión en Alanos el 6 de mayo, y aquel mismo día dio su obediencia Terán en Guadalupe, expresando apelar del anto de la andiencia por hallarse entendiendo en el real servicio con notivo de la sublevación, y por haber dado cuenta de todo a la at1diencia y al virrey, a quien tocaba por Capitanía General o por gobremo, y si no, apelaba ante el rey en el Consejo de Indias. Para mayor fracaso Ruiz Cintrido no halló a los diputarlos condenados. para sacarles las multas, y así hubo de remitir la provisión con. todo lo actuado en su consecuencia. $\$ 8$

$Y$ así llegamos también al momento crítico de esta contiencla. En Alamos el 9 de mayo --tres días después de la entrevista con Terán, nno antes de hacer remisión de la anterior provisión a la audiencia- Ruiz Cintado esgrime la segunda real provisión de 21 de abril, da su obedeciniento a lo en ella dispuesto, y convocá a diez hombres residentes en aquel real para que se apresten con sus armas a respaldar su acción judicial ejecutiva, pena de clos mil pesos y prisión a los mercaderes y mineros: y de closcientos pesos y destierro a China a los demás. Entre los que se pusieron a las ordenes de Ruiz estaba precisamente don Blas de Guznnán. ${ }^{\circ}$ Te lo que después ocurrió tenemos doble información debida a Ruiz y a Terán. Ruiz, a lo que parece, debienclo proceder a arrestar a éste, resolvió actuar rápidamente y en silencio para evitar esć́n-. dalos, y así, poniéndose en marcha con los diez hombres la noche inmediata, llegó al real de Guadaltupe de Paredes a las seis de lá mañana del ro de mayo - a las 4,30, dice Terún--, y dirigiéndose en tres escuadras con todo silencio a las casas reales, desmontaron a la puerta de ellas; llamó Ruiz y le abrieron. Ruiz, Guzmán y sus acompañantes se entraron en la morada armados con sus arcabuces y carabinas - Guzmán llevaba dos - hasta la alcoha de Terán, al

S7 Autos de la audiencia, Ibid., fols. $77-80$; primera real provisión, fols. $80-06 \mathrm{v}$. y segunda real provisión y anto añadiclo, fols. Ioov,-ro5v.

SS Ibid., fols, פ6v.-I00.

89 Ibid., fols, 105v.-108. 
que hallaron acostado, y se arrojaron a prenderle, enseñándole la real provisiór y requiriéndole se diese preso. "A lo cual, alzó (Terán) una voz implorando favor del rey y pidiendo a sus soldados el estandarte de su compañía". Ruiz se esforzaba en ponerle grillos en las muñecas, pero oyendo al alcalde mayor apellidar al rey se despertaron vecinos y soldados, y tomaron también stus armas para ver lo que era, y darle favor; así en pocos momentos salió el alférez don Agustín Jornero con el real estandarte enarbolado v trás él sus hombres, y visto por los del comisionado, cerraron las puertas de la casa de Terán, de modo que Jornero hubo de echar mano de un hacha para quebrar la reja de una ventana y penetrar por la brecha con el estandarte en una mano y en la otra un trabuco cazado. Ruiz Cintado y su adepto el también alférez Tonás de Peralta encañonaron con sus escopetas a Jornero, pero éste y Terán requirieron a los de la audiencia que depusiesen las armas, mientras seguían entrando soldados en la sala. La irresolución de los vecinos evitó un día luctuoso a Sinaloa. Los dos jefes ordenaron a sus facciones se sosegasen y Ruiz cesó en la tarea de proceder a remachar los grillos que ya tenía puestos a Terán, y en cambio le pareció oportuno dar lectura a la real provisión para arresto del alcalde mayor; y leída por éste mismo, dijo a Ruiz. que le soltase y que estaba llano a dar entero cumplimiento y obediencia a los mandatos de Su Alteza, "por cuya razón, y porque no hubo otras personas que se pusiesen a mi lado, aunque imploré el favor al rey $N$. S., por no causar mayor daño, empeños ni alteraciones, hube de sacarle dichos grillos". Como en la provisión se decía que la audiencia daba parte al virrey de lo resuelto sobre este asunto, Terán prometió darse preso hasta que se le quisiese despachar a Guadalajara, y nombrar teniente que gobernase durante su ausencia, aunque algunos de sus partidarios le dijeron que no se debía ejecutar la provisión por tener él dos jurisdicciones. A este acuerdo se llegó estando los de Ruiz a un lado de la. sala, los soldados a otra, todos con sus armas en las manos o a la cintura y mientras Terán se vestía; luego ordenó don Domingo 
traer chocolate y todos lo bebieron, menos Guzmén, quien estuvo paseándose a la puerta con una carabina en la cintura y otra en la mano, hasta que salió Ruiz Cintado, sin consentir que Terán pusiese su ohedeciniento a la real provisión como pretendia, y ambos montaron a caballo y se dirigieron a Alamos, disponiéndose Ruiz a preparar el viaje a Gradalajara, dándolo todo por apacignado.

Segridamente abría Terán infomación para dar testimonio del agravio de que habia sido objeto y bomó sus medidas para evitar ser conducido prisionero a la audiencia. El I tenía Ruiz Gintado noticia de que Terán --a quien al parecer consideraba sometido a arresto domiciliario- había salido de la prisión en que estaba, previniendo toda su infantería y llamando a todos los soldados que tenía repartidos en la jurisdicción y notificando a los vecinos del real le obedecieran y asistiesen, por lo cual Ruiz se clispuso a acudir de nuevo al real de Guadalupe, no sin prevenir antes a todos los vecinos y moradores, estantes y habitantes en la jurisclicción de Alamos para que a las dos de la tarde estuviesen en su casa listos para acompañarle a las diligencias oportunas, guardando obediencia y silencio; les leyó el auto redactado a tat fin a la salicla de misa or

A las siete y media de la tarde llegaba a Guadalupe el algualcil de la grewa de la compañía de Sinaloa, Gaspar Cuello de Fonseca y daba parte a Terán de que habiéndose dirigido con ocho hombres por orden stya a ctmplir ciertas diligencias había sabido cómo don Blas de Guznán estaba en Alamos y la Aduana juntando gente para venir a prender al alcalde mayor; Cuello dio vuelta para Guadaltupe, y en el puesto de Carrizal, en un cruce de caminos halló al nuismo Guzmán con muchos vecinos, que le dijeron se había apostado alli para atajar a toda la gente, ofreciendo dinero a los mulatos y otra gente vil y pobre para que se uniesen.

2o Toda la relación del suceso que antecede se fundamenta en in cabeza de proceso redactada por Terán y confirmada por nueve testigos en Guadalupe, 10-1 I mayn I687. (Escribaniá, 390 A, fols. 94v.-1to), y en el auto de Ruiz Cintado. Guadalupe, to mayo i687 (Guadalajarn, ig, "Testimonio de los autos...", fols. Io\$v.-I o).

91 "Testimonio de autos...", fols. 110-112. 
Guzmán exhibía un auto de Ruiz Cintado, y conninaba a los transeuntes a que se le agregasen, pena de dos mil pesos si eran mercaderes, quinientos si mineros, doscientos a los denás españoles y cincuenta y un año de presidio en Casas Grandes a los mulatos y coyotes. Tenía a su mando ocho hombres que montaban a caballo a la llegada de algún pasajero, para interceptarlo. Enterado Cuello quiso pasar adelante; quisieron impedírselo éstos, echaron de nuevo mano a las armas los soldados, y se abrieron camino porque algunos vecinos fueron dándoles campo para que no stucediera mayor tımulto del que amenazaba, y así pudieron llegar al real. En vista del suceso, mandó Terán tocar a recoger, y se juntaron todos los soldados y vecinos mineros y mercaderes; se les notificó la novedad, y todos se ofrecieron a servir al rey y a su estandarte, y comenzaron una vigilia que duró toda la noche. ${ }^{92}$

A las siete de ella había llegado Ruiz al mismo Carrizal $y_{1}$ leyó la provisión a todos los ya congregados. A las nueve estaba con sir gente - tal vez pasaban de setenta hombres, como dice Terán- en el paraje de Osobampo, a dos leguas del real, y allí salió a su encuentro el Br. Sáenz de Carrizosa y le intimó se detuviese pena de excomunión, porque si seguía se perdería la provincia, avisándole además que Terán tenía preparados más de cien hombres. Ruiz leyó la provisión al cura, y éste dijo que volviese alguno con él para hablar con Terán; el comisionado nombró a don José Rojo de Briones, que marchó con el vicario y no volvió hasta la mañana "diciendo que decía el alcalde mayor que no entrara (Ruiz) porque se habían de matar, y que no lo dudaba por la mucha prevención y gente con que me estaba esperando, pues tenía gente emboscada a estilo de guerra, con nombre dado a la entrada del real por donde había de pasar, y viendo el peligro tan conocido, mandé prevenir mi gente para entrar en dicho real de Guadalupe a hacer la dicha diligencia que se me comete". Efectivamente se puso en marcha el juez de la audiencia, hasta llegar

92 Cabeza de proceso formada por Terán, Guadalupe, i 2 mayo I687, y declaraciones de testigos, I 2 -I 4 mayo. Escribanía, $390 \mathrm{~A}$, fols. I Io-r 20. 
a una legua del real, y entonces envió a don José Rodero, don Diego de Aguilar y Juan de Buiza para que requiriesen a Terán prara que le dejase obrar como a stu juez, que le había preso, pero volviendo le dijeron "que respondió que no quería ni consentía que cosa alguna se le notificase, ni oía nada", y que "tenía toda su iniantería, mercaderes y vecinos en dos alas puestas al armal, a punto de guerra, con el estandarte real". Iban y venían mensajeros. A este tiempo actrdieron dos franciscanos - Fr. Bartolomé Gárcía, custodio, y Fr. Domingo Estévez- a exhortar a Ruiz Cintado que se retirase, y por esto y la censura que le impuso Sáenz de Carrizosa "y otros pretextos y fundamentos" que tuvo decidió el comisionado volverse a Alamos, no sin antes despedir a los que le acompañaban, de los que alguna parte iban pasándose al canpo de Terán. 93

Aquí cesaron las amenazas de rompimiento, después de haber se enseñado las armas por tres veces, sin que llegase a dispararse el primer tiro. Ruiz y Terán enviaron sus autos e informaciones, aquél a la aucliencia, y éste al virrey. Quedaba por ver la polénica entre estas dos autoridades. Según Ruiz, Terán había dicho "que si le vinieran diez mil provisiones con setenta mil pesos cada una de multa, no había de obedecer si no era a su capitán general".

$Y$ la audiencia, al disponer la segunda provisión había repusnado esta actitud: Terán pretextando un ejemplo dado por el virrey Lemos en Perú, había nombrado diputados del comercio en Guadalupe, sujetándolos al Consulado de México y negando absolutamente el conocimiento de las causas de sus vecinos a la audiencia, previniendo por anticipado no se diese cumpliniento a las provisiones que ésta despachase. Cuando llegó a México la carta en que la audiencia comunicaba al virrey su intimación a Terán para que compareciese ante ella, rogando a Monclova nombrase quien supliese al alcalcle mayor, el virrey la pasó con los autos remitidos por Terán sobre fundación del real al fiscal de México

93 Autos de Ruiz Cintado, I I, I 2 y I 3 mayo I687 en "Testimonio de autos...", fols. I r 2-115 y doc, cit, en nota anterior. 
y a su asesor general. Don Pedro de la Bastidal y don José de Aguirre estuvieron concordes en señalar los excesos cometidos por la audiencia, si bien el primero tachaba, además, de lo mismo a Terán.

Para el fiscal, Terán había obligado a los vecinos a poblar en Guadalupe; había procedido a erigir la población sin facultades ni orden del virrey para ello; estaba obligado por su título a dar apelaciones de los asuntos puramente políticos a Guadalajara, y había desobedecido dos provisiones de la audiencia. Esta erró en no dar parte al virrey de la primera como lo dio de la segunda, $y$ por parte de 'Terán era meritorio el haber formado una población, aunque equivocase el modo. En conclusión, el fiscal sostiene que el virrey debe mantener a Terán en su oficio militar y negar a la audiencia poder para privarle de él, y menos sin avisar al virrey; debe ordenar a Terán cese en sus métodos de población y admita las apelaciones para la audiencia. Esta quedaría autorizada para multar al alcalde mayor y obligarle a devolver las multas que sacó a Guzmán, pero no a privarle totalmente del oficio y prenderle, porque las provincias no podían: quedar sin un jefe militar.

Aguirre modifica el parecer de la Bastida en el sentido de que Terán no procedió sino a instancias y con consentimiento de los vecinos y dio aviso de todo al virrey Paredes, y luego a Monclova; y el mismo fiscal había aprobado su actuación al decir eran convenientes estas poblaciones. Sostiene luego que Terán obedeció las reales provisiones de la audiencia, aunque no les diese cumplimiento por haber causa bastante para ello, como era informar al superior los excesos del mismo Terán, que alguno había habido, sólo habían de ser castigados por el virrey, como único juez competente para el caso, según había establecido la real cédula de I 3 de marzo de 1782 que había inhibido a la audiencia en beneficio del virrey, de conocer en las causas de los individuos que ostentasen cargos militares. De ahí resultaba ser intolerable que la audiencia hubiese determinado prender y echar grillos a un cabo militar tan superior como Terán - tenía título de teniente de capi- 
tán generat-- y mandarle comparecer abancionando puesto de tanto peligro como Sinaloa sin licencia de su capitán general. Y era grave que tu jucz inferior pusiese grillos a un militar y se adjudicase luego el gobiemo, habiendo llegado Ruiz a recibir la obediencia de los vecinos, siendo este oficio de la provisión exclusiva del virtey. La torpeza de la andiencia habia originado bandos y tumalios, poniendo a la gente a punto de acometerse. En fin, la audiencia tenia jurisdicción sobre Terén en lo civil, pero no pedia actuar contra su persona; y estaban el presicente y oidores subordinados al virrey en materias de jurisdicción miliar, como lo estaban en las de gobierno, grerra y hacienda por leyes $44-52$, título 15 , libro 2. de la novísima Recopilación de Indias. Lo cua] no obstaba para que el virrey, por atención al presidente de Guadalajara, le renitiese ciertas causas sobre individas residentes en su territorio, teniendo como tenía facultad para comisionar un atior de Néxico que pasase a Nueva Galicia. La audiencia, segun Agnirre, podía enviar pesquisidores, pero sólo en asuntos de justicia y no contra militares y sus privilegios y la jurisdicción privativa del virrey.

Para el caso de Terán, Aguirre proponía que Monclova to hiciese parecer por procurador; 10 mantuviese en sus cargos; le hiciese admitir las apelaciones para Guadalajara, contenerse en los medios para poblar Gnadalupe y reintegrar las multas a Guzmán; y se reservaria el virrey el proceder contra los antores del motín, enviando para ello un comisionado, o $u n$ juez togado de la audiencia de México, ol nuevo teniente de capitán general de Nueva Galicia, y los culpables serían remitidos a México. El virrey se atuvo en todo al parecer del asesor general, y en estos términos dio s11 mandamiento de 25 de junio de 1687 , obedecido por Terán en Gradalupe el 6 de agosto siguiente. 24

La audiencia no podía menos de acudir al rey 95 al ver cómo

94 El manclamiento de Mouclova (Escribanía, $390 \mathrm{~A}$, fols. t20v-140) recoge la corta del presidente de Guadalajara y los pareceres de asesor y fiscal.

95 La audiencia a S. M., Guadalajara, 26 mayo izos. Guadalajara, 20. 
era recortada su jurisdicción, pues pocos serían los individuos que no escapasen de ella alegando ser militares, y considerando ofensivo el parecer de Aguirre. El Consejo de Indias le dio: lai razón : el conocimiento de las culpas de Terán correspondía privativamente al Tribunal de Guadalajara, y para ello le remitiría los autos y presa la persona de Terán el nuevo virrey conde de Galve. Pero, añade la real cédula de 28 de junio de 1689 , "estareis advertidos que en casos de esta calidad no habéis de pasar a remover ni llamar ningún teniente de capitán general que ejerza administración de justicia sin que primero hayais dado cuenta de ello al dicho mi virrey y sin que éste haya puesto persona que sirva lo militar... extrañándoos como lo hago el que pasárais a mandar prender, multar y privar de oficio al dicho don Domingo sin la circunstancia referida". Sin embargo, el Consejo estinaba que Terán había incurrido en desacato ante la audiencia y por ello le multaba en doscientos pesos, independientemente del castigo que después del proceso le impusiese ésta. ${ }^{6}$

\section{POLÉmica SOBRE LOS títulos REALES}

La última década del XVIII trajo a las provincias costeras una galería de justicias nombrados directamente por el rey, que vino de esta manera a superponerse a los tradicionales cuadros institucionales vigentes descle hacía siglo y medio. El primero de estos nombramientos se hizo en I687, a favor de don Manuel de Agramont, designado capitán y gobernador del'presidio de Sinaloa. Tras él vinieron, en I69o, don Melchor Ruiz, alcalde mayor de Sonora, y don Cristóbal de Agramont y Arce, nombrado para Culiacán; el 92, don Francisco Cortés, justicia de Rosario; en el 95, don Jacinto de Fuensaldaña obtenía el de Sinaloa, como futura para cuando se produjese vacante. En i joo proveía el rey por segunda vez la alcaldía de Culiacán, siendo ahora el benefi-

96 R. C. 28 junio 1689 a la audiencia. Escribanía 390 A, autos de la residencia de Terán, cuaderno $20^{\circ}$, fols. I-2. 
ciario don Domingo Orea de Bóveda, y la futura de Sonora, concedida a don Bernardo Bustimunte Bustillo, para cuando cesase el gobernaclor de Nueva Vizcaya, Larrea, que la había asumido. 97 Son, pues, seis en total los nombramientos hechos directamente por el rey en el siglo XVIII para empleos de justicia en Sonora y Sinaloa. Los motivos de esta innovación radican en la posibilidad de obtener así, mediante donativos de los agraciados, algún candal para el exhausto erario de la nación; y en otros casos, pues la explicación antecedente no es en modo alguno de validez general, el rey otorga uno de estos cargos como remuneración y distinción hecha a un militar, al que no halla otra manera de agradecer los servicios prestados.

Por lo que se nos alcanza, la novedad se admitió sin protesta en casi la totálidad de los casos. Los únicos en alguna manera lesionados eran los virreyes y gobernadores en cuanto a la amplitud de sus facultades. La excejción, por tratarse de un cargo vitalicio cuyo propietario no podía ser llanamente expulsado de él, la constituyó una vez más la alcaldía de Sinaloa, que llevaba decenios convertida en objeto de debate entre las tres principales autoridades de Nueva España.

Es el caso que la real cédula de 22 de diciembre de $1685^{98}$ había venido a hacer vitalicio el empleo de capitán del presidio de Sinaloa - como las plazas semejantes en el de Cerro Gordo y en los de Conchos, Gallo y Cuencamé, de nueva creación- estableciendo además que las vacantes se proveyesen por el virrey, de una ternál de candidatos que le presentaría el gobernador de Nueva Vizcaya. Con este trámite fue designado don Diego de Quirós, que se hizo

97 Títulos de don Manuel de Agramont, 30 mayo I687 (Archivo General de Simancas, D. G. Tesoro, İI-195 y Escribanía, ISi B, Autos Agramont-Quirós, IfI8); Melchor Ruiz, R. D., ro cliciembre 1690 (Guadalajara, 3); don Cristóbal de Agramont, 25 junio r $69 \mathrm{r}$ (Archivo General de Simancas, Dirección General del Tesoro, I71-35), don Francisco Cortés, R. D., 28 abril I692 (Guadalajara, 3); den Doningo Oxea, 22 enero izoo (A.G.S., D.G. Tesoro, I73-57); y don Bernatrdo de Bustamante, 23 abril 1700 (A.G.S., D. G. Tesoro, 173-148\%.

98 Esta real cédula se halla extensamente copiada en numerosos expedientes del Archivo General de Indias y concretamente en los "Atutos que sigue... Agramont con... Quirós...", Escribanía, I8I B, 4-Io. 
cargo de la provincia en diciembre de I688, siendo sus títulos datados en 3 de marzo de I687.99 Grande debió ser su sorpresa, y la del virrey Monclova que lo había nombrado, cuando en noviembre de este mismo año presentó su título de gobernador y capitán de la provincia de Sinaloa don Manuel de Agramont: el título en cuestión había sido expedido en Madrid, el 30 de mayo de I687, expresaba ser el empleo concedido vitalicio, y en cambio omitía cualquier alusión al hecho de que por la cédula de ${ }^{6} 68_{5}$ se habjá, ordenado que la provisión de este puesto había sido dejada al virrey a propuesta del gobernador de Nueva Vizcaya. ${ }^{100}$ Monclova se quejará seguidamente de lo que para él, como virrey, significaba este hecho junto con otros similares: de las ciento treinta alcaldías que podía proveer el virrey de Nueva España, sesenta eran sólo para gente miserable, sin méritos ni suficiencia que examinar; su cuantía era tan insignificante que más que provisión de empleo parecía repartimiento de limosna. De las otras setenta, las doce de primera clase valían tanto como las cincuenta y ocho de segunda y tercera juntas; las cuarenta de tercera valían realmente bien poco. $\mathrm{Y}$ para desesperación de Monclova, en el momento de hacerse él cargo del virreinato, el rey había decidido, al parecer, proveer por sí mismo las treinta alcaldías de primera y segunda clase. ror

Viéndose ante el nombramiento de Agramont, Monclova decidió símplemente no darle el pase, juzgando que no podia ir contra los derechos justamente adquiridos por Quirós, y se valió del medio de hacer a Agramont sargento mayor del presidio y ciudad de Veracruz, puesto en realidad mucho más honroso e importante que el que el rey le había concedido, aunque peor retribuido y de mal clima. Un año después le devolvió el título de Sinaloa sin ha-

99 Ibid, 39v. -43 v. y $47-49 v$.

I oo Hemos reproducido a la letra el título de Agramont páginas atrás, en este mismo capitulo.

Ior Monclova a S. M., Lima, I5 junio I69o; en esta carta inserta otra datada en México, I5 enero r688 (Moreyra y Paz Soldan, Mantuel, y Céspedes del Castillo, Guillermo: Virreinato peruano, Documentos para st historia, I, Lima, 1954, doc. 8, págs, 28-43). 
ber proveido nada sobre él. Entonces don Manuel de Agranont reclamo ante el nuevo virrey conde de Galve sirviendole de apoderado su hermano don Francisco de Agramont, ex-gobernador interino de Nueva Vizcaya. Ellos dos y un tercer hermano, don Cristóbal, alcalde mayor de Culiacán, vendrian a constituir uno de los típicos clanes faniliares de las provincias fronterizas.

Así, desputés de la dilación ideada por Monclova, vino a plantearse la polémica cuando ya Quirós estaba en posesión del gobiemó de Sinaloa. La pligña duró hasta IGg y no vino a resolverla otra cosa que un nuevo mandato del rey, pues las autoridades de Nueva España, por más reflexiones juridicas que hicieron, no lograron ponerse de actierdo sobre ios derechos de cata nowo de los litigantes.

Don Diego de Quirós, que había nombrado apoderado 3 don Pedro Pérez de Barreda, capatáz y emblanquecedor de lá Casa de Moneda, quien a su vez sustituyó su poder en don Andrés Bernardo de Quirós, contradijo la pretensión de su contricante sosteniendo que su propio nombramiento, legítimamente hecho por el virrey, era vitalicio. Sobre esto podía además presentar el defecto del título de Agramont al no respetar la real cédula de 1685,111 remir Agramont la condición en ella prevenida de ser soldado experimentado en la guerra de la frontera, nientras él era sargento mayor, grado obtenido en Nueva Vizcaya, y él y su padre se habían cledicado siempre a su costa a aquella guerra. En cambio, "los servicios hechos a S. M. en Flandes $n o$ deben ser remunerados por mayores que los hechos legitimamente en estos reinos, que aum exceden por los trabajos, hambres y secies a los mayores de Enropa, caminando por despoblados crecido núnero de leguas sin seguridad alguna, sin ver ni saber clónde están los indios enemigos, que acometen tan de impuroviso como es notorio... no siendo ignal milicia ni apropósito la de Flandes, Cataltña y la Armada para fronteras de indios, donde si se observaran aquellas reglas militares era preciso enviar cada día tropas de soldados con quien acabaran en breve los naturales". Favorable a Quirós se 
manifestó el fiscal de lo civil, don Benito de Novoa Salgado, a quien consultó el virrey, y que expuso que sólo el rey podía lícitamente anular el derecho que conforme a la ley había adquirido Quirós, no siendo bastante para ello el título de Agramont ni la posterior real cédula de 23 de junio de 1689 que ordenaba al virrey dar posesión a los individuos designados por el rey para cargos que antes había aquél provisto. ${ }^{102}$

La postura de Agramont era más complicada y difícil de defender. De una parte tenía que argumentar y atestiguar haber presentado su título antes de que Quirós tomase posesión, aunque Monclova no quiso darle el pase, y aún en I689 no constaba que Quirós hubiese jurado el cargo. Luego establecía que tanto Monclova como el rey se habían limitado a dar una "futura" para cuando vacase el empleo, y siempre sería preferente la del rey. Incluso siendo el nombramiento de Quirós hecho a título personal por Monclova, había aquél perdido sus derechos al no tomar posesión antes del cese del virrey. Añadía Francisco Agramont: "La parte contraria, sin ser mi intención más que decir la verdad, tiene muy pocos (servicios) en parte alguna, porque la profesión y ejercicio de su padre y suya no fue nunca de soldados, sino mineros, en cuya ocupación estuvo siempre el dicho don Domingo de Quirós, hasta que habrá como trece o catorce años que se graduó de capitán y sargento mayor de la milicia del Parral, sin haber servido antes ni después que lo fue, salvo alguna entrada que por su misma conveniencia haría, por que no estorbasen los indios el ejercicio de la minería, como suelen los demás vecinos, y porque rara o ninguna vez sale ni ha salido la milicia del Parral contra los indios; y el puesto de sargento mayor en aquella tierra sólo es un título ad honorem para poner alguna cruz o recibir alguna procesión y al gobernador cuando entra", lo cual era generalmente notorio en Nueva Vizcaya "y a mí como quien estuvo en ella muchos años y fui gobernador y capitán general de aquel reino".

ro2 Dicha cédula se halla en Autos de Agramont-Quirós, Escribania, I8r B, fol. 93 T. v.; el dictamen de Novoa en fols. 60v.-62v. 
Estas frases darían pie al representante de Quirós para escribir que seguramente don Francisco de Agramont, como práctico militar, debió en su tiempo de gobernar crear sargentos mayores y capitanes como los que pintaba. Don Francisco, en cambio, intentaba perstudir de que en Sinaloa no había indios hostiles, $y$ la tropa del presidio se destinaba a proteger la costa de los piratas que merodeaban por allí hacía cuatro años, y en estas funciones tendría aplicación la experiencia militar europea de su hermano. Finalmente, según los Agramont, Quirós se había posesionado de Sinaloa de manera irregular, por cuanto se adelantó varios meses al cumplimiento del tiempo por que estaba provisto Terán - no obstante declarar éste que entregó la vara a Quirós por orden que para ello tuvo del virrey. Esto le llevará a demostrar que las alcaldías se concedían, antes de la cédula de 1685 , por dos o tres años.

De parte de Agramont se puso el asesor general del virreinato, licenciado don Alfonso Arriaga Agïero, ${ }^{103}$ que hará formar las listas de los provistos en los últimos veinte años en los empleosi militares de las fronteras de indios, mientras don Francisco Agramont las hacía sacar de 1640 a 1670 . El 25 de enero de r6go dio su parecer Arriaga haciendo notar que el título de Agramont. para el empleo de Sinaloa hacía constar la cláusula de "que yo por la presente os recibo y he por recibido a él y a su uso y ejercicio", y que las cédulas de 23 de junio de 1689 ordenaban entregar el puesto a don Manuel. Pero más interés encierran estas frases: "En materia de mercedes y gracias, lo que necesita la del príncipe delegante para su prelación a la del delegado es la anterioridad o igualdad en el tiempo de su data, no el que derogute la facultad del delegado para hacer o haber hecho la merced misma, ni que en la sttya se ate el delegante a las solemnidades prevenidas para el delegado". Con esto quedaban salvados los vicios 11 omisiones del título de Agramont y Arriaga podía promover se le pusiera en posesión. En decreto del mismo día dio su aquiescencia el virrey.

103 Ibid, fols, $85 v,-87$. 
Lejos de resolver la cuestión, esto la complicó, porque el apoderado de Quirós, Pareja, pidió que se pasasen los autos a la audiencia - sin perjuicio de lo determinado, como pareció al asesor. Y la audiencia sentenció el ir de marzo revocando el auto del virrey de 25 de enero y remitiendo la solución del pleito al rey. Lógicamente, correspondió ahora al procurador de Agramont, Juan Leonardo de Sevilla, pedir se le admitiese stpplicación para representar la justicia del títtilo real de Agramont, pero la audiencia resolvió en definitiva el I I de mayo sostener la decisión adoptada dos meses atrás. Los autos fueron, por último, enviados al Consejo de Indias, mientras el conde de Galve informaba que Agramont seguía desempeñando bien el cargo que provisionalmente se le confirió en Veracruz.

El Consejo, cortando aquel nudo gordiano sin desatarlo, se negó a ver el problema como pleito y se limitó a expedir sobrecartada la real cédula de 23 de junio de 1689 para que Agramont fuese admitido al ejercicio del gobierno de Sinaloa. Institucionalmente, la polémica no había sido resuelta. En la práctica, Quirós se había desacreditado militarmente en la guerra contra los sublevados tarahumaras, y el virrey en $3 \mathrm{I}$ de marzo de $\mathrm{I} 69 \mathrm{I}$ 10 desplazó para colocar en su lugar a Agramont.

El problema volvería a plantearse. El i 5 de mayo de 1606 murió Agramont, ${ }^{\text {to4 }}$ y el obispo-virrey nombró en su lugar a don Andrés de Rezábal, sobre las mismas bases de la cédula de I685, ${ }^{\text {ro5 }}$ y la sorpresa volvió a repetirse cuando don Jacinto de Fuensaldaña presentó un título para el gobierno de Sinaloa expedido por el rey el 2 de agosto de 1695 . El nuevo fiscal de México estuvo ahora por Fuensaldaña: decía el licenciado Juan de Valdés ${ }^{106}$ que la cédula de 1685 attorizaba al virrey para nombrar cabos vitalicios de los presidios, pero no capitanes gobernadores vitalicios, y esto íltimo era lo que proveía el rey. La gra-

ro4 Autos de f́uensaldaña con Rezábal, pieza núm. 4, fol, 49, Guadalajara, 54. I05 Ibid, núm, 3, fols. 90v,-91v. Decreto del virtey, México, 2 I agosto I696.

Los títulos expedidos en $2 \mathrm{r}$ agosto $\mathrm{y} \mathrm{I}^{\circ}{ }^{\circ}$ setiembre siguiente.

I06 Ibid., núm. 3, fols, 26-29. 
cia hecha a Fuensaldaña llevaba, además, en sí un contrato, puesto que el provisto había hecho un servicio pecuniario al rey. En resumen, aunque Rezábal no dejó de hacer sus protestas, Fuensaldaña pasó a ejercer el mando de Sinaloa, y si algo después fue depuesto de tal mando, ello se debió a los malos antecedentes que sir contricante logró probarle. 



\section{LAS RELACIONES ENTRE LOS GRUPOS}

\section{A DIVERSA CONDICIÓN DE LOS INDIOS}

Y DE LAS PROVINCIAS

La vida cotidiana en Indias es muy distinta de unas a otras provincias según exista o no en ellas una capa de población constituida por las naciones indias sometidas: ello había de influir, por supuesto, en la estructura económica de los países y en su jerarquización social. Nosotros advertimos la diferenciación qule en las alcaldías costeras al norte del río Cañas introduce el hecho de que, en las provincias meridionales de Nueva Vizcaya, sea inexistente o casi inexistente la población india, mientras que de Culiacán al norte forma ésta un poderoso núcleo.

Seguidamente se señala otro importantísimo factor de diferenciación : las misiones. Culiacán no es país de misión. Los indios, sujetos desde I530, están constituidos en la clase de tributarios, verdaderos vasallos de la Corona de Castilla, sean sus relaciones con ésta directamente, a través del alcalde mayor, o indirecta. mente, por medio del encomendero. Su cristianización está a cargo de éste o de los clérigos de la villa. El alcalde mayor atenderá a sut gobierno temporal.

No ocurre lo mismo una vez pasados los confines de este enclave de Nueva Galicia. Sinaloa, Ostimuri y Sonora son tierras de misión: los pueblos indios se hallarán bajo la influencia directa de los padres de la Compañía de Jesús, cuya presencia se hará notar de manera acusadísima en la vida de las tres alcaldías, y no sólo como evangelizadores, sino como el tercer elemento en juego 
en el que de otro modo sería simple diálogo de los españoles con los indios.

Porque la tipificación que se ha hecho del misionero como instrumento a un tiempo de la Iglesia y de la Corona no alude al tan típico enfrentamiento del misionero con los españoles, y no siempre en defensa del indio, como se podía presentar el hecho tras una fácil alusión al padre Las Casas. El problema es bastante más complejo, apasionante $y$, sobre todo, delicado.

Lo dicho muestra cómo, en la porción de costa que estudiamos, se hallan tres tipos de sociedad: la de los españoles solos - comprendidos en este nombre todas las mezclas de "gentes de razón."-; la de las provincias con indios tribttarios organizados en curatos; la de los países de misión cuyos naturales se hallan en régimen de tutela por los jesuitas.

\section{ENCOMIENDAS, ESCLAVITUDES Y TRIBUTOS DE INDIOS}

Tanto en la gohernación de Nueva Vizcaya como en la de Nueva Galicia hubo encomiendas de indios, si bien en la primera fueron de escasa duración y de aún menos importancia. Muy recientemente ha apuntado Gallegos su existencia - hasta entonces desconocida - en los primeros momentos de la historia de Durango. I Nosotros podemos añadir una serie de noticias que cubren todo el siglo, aunque havamos de concluir mostrando la insignificancia de esta institución en las provincias costeras de Nueva Vizcaya.

Ya en i646 proponía el gobernador don Luis de Valdés que se diesen por vacas todas las encomiendas de Nueva Vizcaya, por no estar confirmadas por el Consejo de Indias, dándose en cambio facultad a los gobernadores y justicias para hacer los repartimientos que más conviniesen a los mineros y labradores, a lo que se proveyó ordenando al virrey informase qué encomiendas eran

I Gallegos C., José Ignacio: Durango colonial ( r $_{5} 6_{3}-1821$ ). México, Jus, I 960, págs 108-iro. 
éstas, quién las gozaha y con qué merced, y en qué forma se poseían, pero recomendando que se confirmase mediante composición, cuyo producto se enviaría a la Casa de Contratación. ${ }^{2}$ Se ignoran las consectrencias de tal orden. El testimonio de Valdés es concluyente en cuanto a la existencia de encomiendas en su gobernación, y al mismo tiempo explica la escasez de datos que padecemos acerca de ellas, puesto que sus beneficiarios no acudian a obtener la confirmación real. Esto aclara también el que, en el escrito de Juan Díez de la Calle titulado "Virrey, presidente y gobernadores que tienen facultad de encomendar los indios de st distrito", sólo figuren, dentro del virreinato de Nueva España, los gobernadores de Yucatán y Nuevo México, haciéndose omisión del de Durango y del gobernador-presidente de Guadalajara. 3

Que los gobernadores de Nueva Vizcaya, con facultad o sin ella, procedían a encomendar indios en fecha aún más tardía es cosa que se demuestra claramente con sólo reconocer en el "Libro de gobierno de títulos y mercedes que hizo el gobernador don Antonio Oca Sarmiento en el reino de la Nueva Vizcaya", la encomienda de los indios sumas de Carretas que éste confirió al capitán Bernardo Gómez, en Parral, el 6 de noviembre de r668. 4 Obsérvase también que este proceder de los gobernadores no fue jamás, que sepamos, objetado por la audiencia, los visitadores, ni los jueces de residencia, nuevo motivo por el que el hecho ha podido permanecer desconocido hasta hoy para el historiador. Por otra parte, pese al testimonio últimamente aducido, también es posible encontrar que el gobernador Gorráez, en fecha algo posterior, niega taxativamente la existencia de encomiendas en Nueva Vizcaya, 1o cual al menos probaría su nimia importancia en la vida del país. 5 Resistióse Tbarra en 'Chiametla, al decir de Obregón, a dar ser-

2 Valdés al rey. Parral, 28 febrero i64.6. Guadalajara, 2S. R. C. is enern I648. Guadialajara, 230, Z, 3, 46-47.

3 BN, Mss, 3.046.

4 Escribanía, 397 A, pieza I, núm. 2I de los Autos de la Residencia, 126r.I $27 \mathrm{v}$.

5 R. C. 4 marzo I673. Guadalajara, 231, Z. 4 , So r. v. 
vicios personales, limitándose a ofrecer a los pobladores, para más adelante, "repartimiento de servicio personal para el beneficio de sus casas". 6 Dice un testimonio posterior que los indios, en cuanto se les quería hacer una imposición, se alzaban a los montes. En las relaciones de repartimientos y encomiendas de indios vacos en Nueva España, como la hecha en I6Ir, no figuran las concesiones que tal vez hicieran los gobernadores de Nueva Vizcaya. 7 Si tales concesiones se hicieron por Ibarra o sus sucesores, sería contrariando al menos la voluntad expresa de Felipe II, constante en la instrucción dada al oidor Morones en cédula de i I de febrero de 1560 para el poblamiento de aquella provincia, 8 ratificada en términos generales años más tarde a Urdiñola en real cédula de 4 de abril de r6og en que, al aprobar que no se apremie a los chichimecas a trabajar en las salinas de Nueva Vizcaya, sino que se procure lo hagan por medios suaves, se añade: "La cédula que está dada sobre que no se encomienden a los indios naturales que nuevamente se redujesen a nuestra santa fe por la predicación del Evangelio, y que sean relevados de tributos por diez años, cumpliréis con toda puntualidad". 9 De todos modos es de fácil comprensión que los indios de Chiametla, de muy bajo nivel cultural y escaso número, ni se prestasen a servir como encomendados, ni fuesen solicitados por ningún aspirante a una de estas concesiones, y así pocas esperanzas de vida tenía este sistema de dominación en la costa de Nueva Vizcaya.

Pasemos a tratar del caso de la esclavitud. No es preciso recordar la prohibición general de hacer esclavos a los indios. Los que hubo de esta condición en Sinaloa y Sonora fueron ré sultado de las sublevaciones y guerras habidas en el país y en las zonas colindantes. Robert $C$. West ha estudiado las capturas de

6 Obregón, II8-iıg.

7 México, 15 noviembre 1611 . BN. Mss., 2.939, I67-172v.

8 Guadalajara, 230, Z I, 38-43. Chevalier, François: La formation des grands domaines au Méxique. Terre et societé au.r XVIe-XVIle sic̀cles. París, 1952. Pág. 5. Mecham, J. Lloyd: Francisco de Ibarra and Nucva Viscaya. Durham, i 927. Págs, 95, 108, 136, I 81 .

9 Guadalajara, 230 Z. 2, 1 25v,-1 26v. 
esclavos que ocasionalnente se produjeron en torno al distrito de Parral y sirvieron para dotar de mano de obra las minas y haciendas de plata del real, y algo por el estilo ocurrió en la costa.

La costumbre de hacer esclavos a los bárbaros strblevados apresados en campaña se recoge ell una carta de Rodrigo del Río de la Loza a S. M., en que dice que ni aun con este aliciente y el del sueldo querían los españoles ir a combatir a los caníbales de las sierras espesísinas de Chiametla. ro Con posterioridad a esta fecha sabemos que continuó sujetándose a esclavitud -aunque sólo temporal - a determinados enemigos y rebeldes en la porción interior de Nueva Vizcaya: a decir verdad, esto no es otra cosa que una condena a trabajos forzados por tiempo limitado.

En Sinaloa no volvemos a tener noticia de algo relacionado con esto sino con ocasión del expediente promovido por el fiscal Haro Monterroso en I6.7 I para extinguir esta costumbre, alcanzando la libertad gracias a st1s diligencias doscientos dos indios en Parral; setenta y dos, en Zacatecas, y cinco en Guadalajara. II Y muy poco después tenía lugar el episodio ya conocido por nosotros en que Haro hizo volver a Sinaloa un grupo de niños que eran conducidos a México, de los que algunos habían sido apresados en campañas contra los seris y otros grupos rebeldes, y otros eran simplemente hijos de indios sirvientes en casas de españoles. ${ }^{12}$ Los concluctores de estos diez indiezuelos sostuvieron siempre que éstos no eran considerados esclavos, sino que eran llevados a casas de españoles en que fuesen cristianamente educados. En: cambio. de sus mismas declaraciones se desprende que antes de la publicación de las provisiones despachadas a petición de Haro por la audiencia solían venderse los rebeldes por diez años a los mineros, pero antes que cumpliesen este tiempo, cuando ya tenían algún cliscurso, se huían a sus tierras. De Nuevo México habían llegado recientemente a Sonora más de treinta presos para ser vendidos

Io Rio de la Loza al rey. Vizcaya, 25 octubre 1591. Guadalajara, 28.

I Haro al rey. Guadalajara, 20 marzo I672, con testimonio adjunto. La audiencia al rey, Guadalajara, 7 abril I 672 , con testimonio. Guadalajara, I 2 .

12 Haro al rey, Guadalajara, 3 julio 1672 , con testimonio. Ibid, 
cono esclavos, pero se les dio la libertad al publicarse las reales provisiones. ${ }^{\mathrm{I}} 3$

La costumbre pudo resucitar, sin embargo, a raíz de las grandes st1)levaciones del ciclo que abre la rebelión triunfante de los indios de Nuevo México. Precisannente al tener noticia de este trágico suceso escribe el mismo gobernador de Nueva Vizcaya al virrey sugiriendo que cuando se hiciese guerra a los alzados se debería permitir que se les tomase por esclayos por diez años, amque lo impedian las leyes vigentes: pero esto animaría a los pobladores a entrar a la reconquista de la provincia perclicla. ${ }^{14}$ Efectivamente, a partir de estas fechas, volvemos a saber, si no de indios dados en recompensa a los pobladores y soldados españoles, si de otros vendidos por diez años: siendo Gironza gobernador de Nuevo México, vendió de esta forma setenta piezas apresadis en una de las campañas preparatorias de la recuperación del reino por Vargas Zapata; y el rey aprobó lo hecho, con tal que los indios vendidos fuesen mayores de edad y que a los diez años se les pusiese en su libertad natural. ${ }^{5} \mathrm{Ha}$ de entenderse que tal medicla, sobre ser un castigo a los sublevados, proporcionaba al erario un resarcimiento aunque pequeño de los gastos que representaban las operaciones punitivas.

Puesta, pues, de nuevo en vigor tal prícticá, la aplicaron en Sonora Verdugo y Cuervo Valdés con algunos indios complicados en proyectos de sublevación, y se producirían otros casos hasta la terminación del siglo: eran los indios que se decían condenados a obraje o a mortero. Verdugo envió con este fin al real de Nacosári por diez años, a los indios Juan Caiso y Francisco Quigue, de Bacuachi, sentenciados el 8 de julio de I68r ; su teniente general a guterra Juan Bautista de Escorza aplicó la misnna pena a Juan Saguori, gobernador de Bacadeguachi, por diez años, y al topil Lorenzo Curita, por cuatro, el 24 de julio del mismo año, siendo

I3 Declaraciones de Nicolás Ramos, Alonso Rascón y Juan de Mendoza eı testimonio citado en nota anterior.

14 Bartolomé de Estrada al virrey. Parral, 22 julio I680. Guadalajara, 138 .

I 5 R. C. 2I jtulio I6gI al virrey. Guadalajara, 232, Z. $7,89 v,-92$. 
su sentencia confirmada por Cuerro el 3 de agosto siguiente. De los dos primeros se dice que su trabajo se pagaría a razón de tres pesos al mes en concepto de servicio personal, siendo esta cantidad aplicada por tercios a la cámara real, a la fabricación de cárcel en el real de San Juan Bautista y a los gastos de la expedición hecha para dominar la sublevación en ciernes. Cuervo pone precio a Saguari en cien pesos, y a Curita en cincuenta, aplicados por mitad a la cámara y a los gastos de visita. ${ }^{16}$ Resulta curioso que, puesta en corriente esta práctica en la gobernación de Nueva Vizcaya, fuese en cambio repudiada en Cuervo como abusiva por el fiscal de Guadalajara don Pedro de Barreda. ${ }^{17}$

Culiacán ofrece, según se ha dicho ya, el único caso en que, en las alcaldías costeras, arraigan y perduran las encomiendas, $y$ en que los indios pagaron tributo, bien a sus enconnenderos, bien al rey, lo que no se dio en toda la gobernación de Nueva Vizcaya, según proclaman repetidas veces sus gobernadores para explicar por qué los alcaldes mayores no afianzan el cobro de este derecho, como era obligado, ${ }^{18}$ e incluso en 1682 , a consecuencia de un informe hecho por el gobernador oidor don Lope de Sierra Osorio, se ordenó por el rey suspender una tentativa para introdıcirlos. ${ }^{19}$ A principios de siglo había en Culiacán algo más de setenta pueblos de naturales, encomendados o en cabeza del rey. ${ }^{20}$ Por supuesto, los encomendados eran los vecinos de la villa de San Miguel, y en 1672 seguían incorporándose pueblos a la Corona. ${ }^{21}$

16 Escribanía, 40o C. pieza 2, cuaderno 8. del proceso de Cuervo, 20-25, 67 v. $-68,78$.

I7 Pedimento fiscal, Guadalajara, 9 setiembre I672. Escribanía, 400 A, pieza :, 224-226v.

Is R. C. 4 marzo 1673. Guadalajara, 231, Z. 4, 80 r. v.

ig Rs. Cs, 5 mayo 1682 al gobernador y al obispo de Nueva Vizcaya. Guadalajara, 23I, Z. 5, rogv.-iriv.

20 "Relación del distrito de la jurisdicción de la real audiencia de la Nueva Galicia y provincias subalternas a ella", remitida con carta de la audiencia al rey, Guadalajara, 28 de abril de 1605 . Guadalajara, 7.

21 Auto de los Oficiales Reales, Guadalajara, I5 setiembre I672. Auto de Calderón, Culiacán, 4 abril 1673. Cuaderno y cuenta del alcalde mayor, 2-2v. Guadalajara, I5. 
Producian este año de 1672 al rey los tributos de Culiacán poco más de seiscientos pesos, de los que los indios pagaban dos tercios en moneda, y el restante en gallinas de Castilla y en maíz. El alcalde malyor tenía, entre otras ocupaciones, que sacar a pregón y subasta pública lo procedido de este tercio para convertirlo en dinero. En el año que conocemos se remató en Andrés González Rodero, vecino de la villa que pagó la fanega de maíz a cuatro tomines, y a an tomín la gallina. sz Debia ser este un buen negocio, pues el mismo alcalde mayor Calclerón compraba el maíz para los trabajadores de las salinas a dos pesos y medio fanega. ${ }^{23}$

Los indios de Culiacán puestos en cabeza de Su Majestad dependian directamente del alcalde mayor y estaban bajo la tutela de un misionero. Percibía un varón por trabajar en las salinas, la comida y el salario de un tomín por día, y aquélla, compuesta de maíz, carne y pescado, podía valer algo más de dos tomines diarios, según se desprende de las cuentas. ${ }^{24} \mathrm{La}$ retribución es baja, comparada con la que la audiencia de Guadalajara establece para los indios de las alcaldías de Sinaloa y Sonora en estas mismas fechas.

\section{Minjsiros, MISIONEROS E INDIOS}

Descartado el caso de Culiacán, que es el usual en las Indias, se nos ofrece, de Sinaloa al norte, la pugna de los mineros con los Padres sobre la utilizaciún de los indios. La relación no se establece sobre la base españoles-indios, que equivaldría a la de dominadores-dominados, sino que el primer componente de esta relación se escinde dejando a un lado a los miembros de la Compañía de Jesús, y al otro a la restante población blanca o de gente de razón. Si a esta segunda fracción la designamos con el nombre

22 Renate de las gallinas y el maíz, Culiacán, is octubre I672. Relación jurada de lo cobrado por tributos, Guadalajara, 21 abril 1674 . Ibid., 19-20v. Guadalajara, I5.

23 Ibid., It 1 . v., 16.

24 Ibid., I $2-13 v .$, I 6. 
de mineros, ello se debe a la principalísima función que la minería desempeña en el país, como que es y siempre se consideró el motor de toda la actividad económica. Tras la suerte de los mineros y la bonanza o decadencia de sus minas va la de los comerciantes y la de los primeros ganaderos de Sonora. Incluso la única excepción que podríamos consignar - la del presidio de Sinaloa- puede insertarse a la larga en el mismo esquema de la minería y sus soportes agropecuarios. Para ellos los indios constituyen la indispensable mano de obra y los proveedores de cereales para toda la población. Por eso los mineros recabarán la prestación de servicios personales mediante o no retribución, y la libertad para comerciar con los pueblos de indios el rescate de granos por géneros.

Del otro lado vemos a los Padres. Su papel en principio se reduce a la predicación del Evangelio entre los indios; bautizarlos, enseñarles la doctrina, atender a la vida espiritual con todos los medios que previene la Iglesia. Puesto que, por la escasez de ciero, en numerosos casos se encargaban también de la administración de sacramentos a los españoles, no era extraño que de alguna manera interviniesen para suavizar, si hacía falta, las relaciones de éstos con los indios. Pero, ¿se mantuvieron en esta actitud? ¿No la rebasaron tan ampliamente como para dar lugar a las quejas y protestas de los vecinos? ¿Y cómo explicarlo?

A todo esto, los indios objeto de la polémica eran, claro está, los del centenar largo de pueblos comprendidos en las misiones. No hay cuestión sobre los indios que viven en los reales, ranchos y haciendas de los blancos, donde seguramente a la segunda generación quedan asimilados como gente de razón. Los indios de los pueblos, puesto que no estaban encomendados, debían ser gobernados por alcaldes mayores. Sus títulos lo muestran claramente, y aún más algunos textos que insertaremos después. La autoridad inmediata sobre los pueblos debía corresponder a los gobernadores, fiscales y alguaciles que los mismos indios elegían, y luego confirmaba el alcalde. ¿Cómo se incrustaron los Padres como tercera 
fuerza, hasta el punto de anular en la mayoría de los casos la de los propios indios?

LA LABOR DE GOBIERNO DE LOS MISIONEROS

La opinión común en las provincias, y la manifestada por la audiencia de Guadalajara, establecen como hecho indiscutible que son los Padres quienes hacen trabajar a los indios en las siembras, administrando luego si producto: "en los principios lo erraron unos y otros, los Padres en aplicarse a imponer a los indios en lo dicho, y las justicias primeras en dejarlo correr así y no, cuidar de ir dando la debida forma y policía a los indios, haciéndoles sembrar para sí mismos y para el abasto común, según S. M. lo manda y está corriente y bien establecido en tierra afuera". ${ }^{25}$

Este fallo inicial se explica por la necesidad en que los Padres se veían, para lograr sus fines espirituales, de comenzar por asentar a los indios en pueblos y de manera permanente, con objeto de que resultase eficaz la continuidad de su predicación y adoctrinamiento. Era punto capital que los indios pudiesen disponer, mediante el apropiado trabajo de la tierra, de recursos alimenticios suficientes como para no tener que abandonar sus casas en busca de las sabandijas, raíces y caza de montes. De lo contrario, o en caso de sequía, los naturales se veían empujados a una existencia seminómada, y en estas circunstancias olvidaban las nociones cristianas aprendidas y volvían a las prácticas de su anterior paganismo.

Los Padres no tuvieron más remedio que acudir a hacer, valer su actividad para que los indios procediesen a sembrar en los tiempos oportunos y en las cantidades necesarias; les hicieron trabajar en algunas obras de regadío, que fertilizasen sus tierras; les proporcionaron algún mejoramiento en su dieta, gracias a las

25 Gregorio López de Dicastillo a Daniel Angelo Marras, S. J. Real de San Miguel, 28 mayo I673. Patronato, 232, ramo I, I 3 I-I 35. 
reses, cuya introducción en la provincia ya hemos narrado, pero que nunca llegaron a ser de los indios.

No cabe duda de que también rebasaron estos límites los Padres, con otros motivos. El primero y más fácil y loable fue la construcción de las iglesias en cada pueblo, edificaciones de materiales pobres, pero a veces de apreciables dimensiones, que poco a poco iban sustituyendo a los humildes jacales de la primera hora. Su construcción y conservación recayó lógicamente sobre los indios, sin que nadie hallase reparo en ello, puesto que todos los fieles deben coperar a las necesidades de este tipo.

Después, los Padres indujeron a sus neófitos a que les sembrasen una milpa para su sostenimiento, de maíz o de trigo, o de ambos cereales, y luego a que les cuidasen, como es lógico, el pegujalito de ganado de que cada misión disponía. Sin duda el temor a que el contacto con los mineros y comerciantes corrompiese la fe y las costumbres ingenuas de los indios movió a los Padres a hacer que todo el producto del trabajo de éstos pasase por sus manos y ser ellos los que tratasen con los españoles o al menos vigilasen las transacciones, en precaución también de cualquier tentativa de engaño por parte de éstos.

E1 resultado fue que los vecinos vieron surgir frente a ellos a los misioneros hechos dueños de las voluntades, las tierras y los productos de los indios, osando incluso oponerse a los "mandamientos" o "sellos" con que los justicias disponían el trabajo de algunos en las minas o siembras de las villas y reales.

\section{EL “Apologético Defensorio" de I657}

A mitad de siglo se veían de nuevo los Padres obligados a remprender la defensa de sus actividades de resultas de los ataques de que se veían convertidos en blanco por parte de los capitanes y quizá de los vecinos de Sinaloa, y desde luego, pervivía el concepto común de los cuantiosos bienes que al parecer habían acumulado los misioneros en las alcaldías setentrionales; por eso 
el fiscal de Guadalajara doctor don Jerónimo de Alzate, se sintió impulsado a escribir al rey en 17 de abril de 1648 sugirientio se retirase la consignación que les pasaba el Erario, "siendo así que tienen fundadas haciendas muy considerables en las más de las doctrinas, hallándose señoreados de los indios, valiéndose de su trabajo para granjerías, lo cual le han asegurado personas celosas de mi servicio" - dice el rey, que desea ser detalladamente enterado de todos estos particulares. ${ }^{26}$ La réplica del Colegio de 1a Villa frente al ambiente hostil es el documento dado a conocer por Herrera Carrillo, titulado "Apologético Defensorio y puntual manifiesto que los Padres de la Compañía de Jesús misioneros de las provincias de Sinaloa y Sonora ofrecen por noviembre de este año de $\mathrm{I} 657$ al rectísimo tribunal y senado justísimo de la razón, de la equidad y de la justicia contra las antiguas, presentes y futuras calumnias que les ha forjado la envidia, les fabrica la malevolencia y cada día les está maquinando la iniquidad". ${ }^{27}$ E1 motivo de los ataques nos es conocido ya, y se perfila aún más a través de las protestas de los misioneros.

Tenía entonces la Compañía treinta y dos Padres en aquellos países, y su actividad iba dirigida y apoyada por el Colegio de San Felipe y Santiago, que ellos mismos presentan como la base económica de las misiones, con su riqueza ganadera, que le permitía comerciar con el real de Parral, enviando sebo, tasajo y cueros a través de la cordillera en grandes recuas, 28 y surtir constantemente los pueblos administrados por sus miembros; que "aviaba" a los pobladores de la provincia cuando se animaban a trabajar alguna mina o hacienda; que les socorría en los viajes, enfermedades y en cualquier necesidad. El potencial ganadero de la Compañía era ya tan fuerte como para hacer factible lo que los Padres cuentan: "sólo en los dos pueblos de Ráum y de Pótam, que son

26 R. C. 2 diciembre 1648 al obispo y oficiales reales de Durango. Guadalajara, $230, Z .3,7$ I-72.

27 Estudios históricos de Sinaloa, México, I960, I45-174.

28 Ibid, I68. 
de los más numerosos de la nación yaqui, repartió el año pasado de 55 su ministro, por espacio de más de cuatro meses continuos, que duró lo riguroso del hambre de aquellos pueblos, más de seis mil raciones de alimento cada clía, contadas y admiradas de algunos españoles que lo vieron". ${ }^{29}$

Los Padres dicen en el mismo título de su escrito que la envidia es una de las cansas de los ataques que se les dirigen. Ante tal alarde de riqueza se comprende esa envidia, aunque los españoles no fueran tan pobres como ellos los pintan, sin caer en la cuenta de su inconsecuencia. Para los autores del "Defensorio" los españoles son la bestia negra de las provincias: pobres, codiciosos, divididos entre sí, causa de la corrupción de los indios, explotadores de éstos. Evidentemente, el escrito no es muy digno de crédito sobre estos puntos. Poca explotación de los indios podian hacer los pobres españoles en las minas, estanzt1elas y hacenduelas que trabajaban ayuclados por el Colegio; ni tampoco podian hacer mucho perjuicio a los naturales los únicos dos mercaderes que tenían tienda en la villa, aparte del capitán. Por lo que podemos atisbar a través de tan confusas noticias, aún no había llegado el momento de la verdadera oposición de pobladores y misioneros; aquéllos se limitahan a criticar el bienestar y la seguridad con que tal vez podían vivir los jestitas. "Oue - se quejan éstos- tenemos grandes cosechas de maíces, de trigos y frijoles, que hacemos exorbitantes siembras, que tenemos gran copia de ganados, mucho número de mulas, grandes almacenes de tejidos, que vivimos en unos palacios, que es grande el aparato y majestad con que caminamos". 30 La retina del poblador era, seguramente, exacta. Las grandes cosechas, cuando no fueran propias de los Padres, eran las de los indios, y los jestuitas no se cuidan de hacer la distinción; los ganados, ya se ha visto su import tancia; las mulas eran precisas, y en crecido número, para los'

29 Ibid. I72.

30 Ibid, 162 . 
constantes acarreos de bastimentos y demás cosas necesarias de unas misiones a otras, para el tráfico con Parral y con México; los tejidos estaban allí para vestuario de los indios, a los que se les distribuía anualmente. Las casas de los Padres, de una sola planta, con tres piezas al frente $y$ un patio trasero, bien podían parecer palacios a aquellos españoles cuyas habitaciones llaman los misioneros "chozas gallegas", y "tabuco" a las mismas Casas Reales de la villa de Sinaloa,

¿Podrá dejarse más clara constancia de la potencia que representaba la Compañía en fecha tan temprana en las provincias? No hace falta discurrir mucho para hallar la fuente de esa riqueza : son los indios. Para convertirlos, y para no fracasar en su empresa, los jesuitas han construido - es sólo una de sus innumerables y magníficas creaciones- un instrumento perfecto. Sinaloa y Sonora ofrecían un estupendo reto. Los Padres han creado la miaquina que lo supere. Obligados en el primer momento a bastarse por sí mismos, cincuenta años después han logrado tuna autosuficiencia abrumadora. Muchos testimonios posteriores darán fe de este hecho que ahora se perfila aquí. El "cómo hacerlo", el "medio" es sencillo: utilizando a sus propios neófitos. Así, la ganadería y la agricultura, y todas las industrias artesanas derivadas de ellas estarán a su disposición; porque no son los Padres quienes siembran, cuidan las reses, ni conducen las recuas. Pero todo el sistema misional se beneficia de que los indios lo hagan. Poco después, el fiscal de Guadalajara y otros personajes sacarán a lız la otra cara de la medalla.

Digamos unas palabras más valederas para la fecha del "Defensorio". Los españoles, a !os que los misioneros, desde la altura de su obra, parecen despreciar un poco, son todavía escaso adversario para ellos. La razón es clara, como lo es la de la buena armonía entre todos desde fines del XVI: mientras los vecinos sean unos pobres y escasos labradores, angustiados ante la perspectiva de una posible sublevación, los Padres serán bienvenidos como 
mensajeros de paz enviados a las naciones indias. Múls adelante, mientras la minería no dé lugar a una modificación profunda de las estructuras económicas, los pobladores sólo advertirán el contraste de su propia miseria con la fuerza y la riqueza que en uin momento determinado podía movilizar una empresa colonizadora y misional de altos vuelos como era la Compañía en Sonoral y Sinaloa.

La villa de los dos apóstoles había llegado a tener en el momento de redactarse el "Defensorio" doscientos vecinos, pero la minería sonorense estaba en sus tumbrales, y este documento sólo habla del real de San Pedro, considerando sin interés algunos otros reducidos núcleos mineros. Cuando algo más adelante surjan los principales reales en Sonora, Ostimuri y Sinaloa, y cuando los españoles se rean necesitados de los productos agrícolas y ganaderos de los pueblos de indios sometidos al inflijo de los Padres, la diatriba con éstos adquirirá verdaderos caracteres de tal y una sorprendente acritud. Los textos de los años 30 y el "Apologético Defensorio" serán sólo documentos que permiten apreciar la formación de un estado de cosas y de un ambiente que prepara el estalliclo de $\mathrm{r} 672$.

\section{LOS SERVICIOS PERSONALES PROHIBIDOS}

Es evidente que entre los Padres se mantenía la idea de que era preciso defender a los indios de los mineros. En I67 I, siendo alcalde mayor de Sinaloa don Mateo Ramírez de Castro, eli misionero de Tehueco, Padre Jacinto Cortés, movía al protector de indios Francisco de Luque para que se esforzase por impedir las exigencias del primero en orden a que los indios de la provincia: acudiesen gratuitamente a desempeñar determinadas faenas en el presidio o en beneficio del propio capitán. Es de advertir que cinco años antes ya Oca Sarmiento, gobernador de Nueva Vizcaya, había dado orden al alcalde mayor de Sinaloa que entonces ejerciese y a sus sucesores para que no sacasen a los naturales con 
"sellos" de sus pueblos si no fuera porque a los mismos indios les conviniese y haciéndoles pagar su trabajo, y llamándolos de modo que no tuviesen que abandonar el cuidado de sus propias milpas, reservando siempre a los cantores y sirvientes de las iglesias. Habían advertido los Padres a Oca que se obligaba a los indios de Tehueco y Bacubirito a ir a servir, sin paga, en las labores de la villa de Sinaloa, a veinte y treinta leguas de sus pueblos. El gobernador mandaba se observasen las cédulas reales sobre estas materias. ${ }^{31}$ En I67 I, desde Tehueco y Charay, el Padre Cortés animaba a Luque para que no permitiese que los indios saliesen de sus casas a trabajar sin paga conforme a arancel. El Padre comisario enviaba sus cartas en el mismo sentido. Y Luque fue a Parral a presentar como apoderado de los tehuecos una demanda en la residencia de Ramírez de Castro, mientras los Padres esperaban que con don Miguel Calderón y don Antonio de Otermín, nuevo alcalde mayor y capitán, se arreglase la cuestión.

Los de Tehueco reclamaban la paga de dos "tapisques" que el capitán hacía ir semanalmente al fuerte de Carapoa. Que en I670 les mandó ir a sembrar una milpa de una fanega en San Lázaro, a catorce leguas de Sinaloa, porque decía que allí llovía más, y tuvo veinte o treinta indios cada semana desde jullio a noviembre que se cogió la milpa y se la desgranaron y encerraron en las ramadas que allí mandó hacer, sin darles paga ni comida a ellos, ni a cuatro indias que tuvo para guardar la siembra los cinco meses, debiendo abonárseles 2 tomines diarios, puesto que no se les dio manutención. Así había cosechado el capitán cien fanegas de maíz, que envió a vender al real de San Miguel; y el año i669, que fue estéril, recogió sólo seis fanegas que vendió en el fuerte a marco de plata. Del mismo modo pedían los indios salario de los días que habían acudido a trabajar en la villa de Sinaloa y en otros servicios, que se les devolvieran "diez fanegas que el teniente Juan Francisco les llevó por la visita del pueblo, y midió el maíz con su

31 Parral, 25 agosto 1666. Escribania, 398 A, pieza I, 59-60. 
almud, que es mucho mayor que el de Nueva Vizcaya, y con él midió también el maíz que les rescató". Aín liabía otras cuestiones sobre alquiler de caballerías de los indios, etc. ${ }^{32}$

Todo esto debió tratarse en la residencia de Ranírez de Castro, que no nos es conocida, y muestra la sujeción a que los capitanes o caudillos del fuerte podían obligar a los indios del contorno, con la tolerancia de los alcaldes mayores en beneficio a veces de los vecinos. No por eso, a su vez, y es significativo, se abstenía el Padre Cortés de enviar indios, por su propia autoridad a lo que parece, al capitản Luque, de ocho en ocho semanalmente para que le envarasen la casa. De todos modos, Cortés menudeaba sus cartas a Luque y al alcalde Calderón para que se quitasen aquellos servicios que con nombre de encomiendas antiguas imponían los del presidio. 33 El misionero estaba dispuesto a excomulgar a cunalquiera que reclamase indios sin paga: "si no es con aranceles, ni vecinos ni soldados han de llegar ni agua". 34

\section{LA CUESTIÓN ANTE La AUDIENCIA}

En noviembre de 1672 se presentaba Francisco de Luque en Guadalajara, acompañado de tres indios mocoritos, y hacía tma larga relación de protesta contra los abusos a que se veían some-1 tidos los indios por parte de los capitanes y vecinos de Sinaloa... y de los misioneros. 35 Después dirán estos que el protector actuó así en venganza por cierto proceso que el juez eclesiástico jesuita de San Felipe y Santiago había abierto contra él, pero es lo cierto que a las acusaciones de Luque se dio crédito por igual en todas sus partes, y que los testigos que presentó abonaron todas sus afirmaciones. No se olvide, sin embargo, que el título de capitán pro-

32 Cartas del P. Cortés a Luque, 1671 y 1672 , en Patronato, 232, ramo 2, $30 \mathrm{v} .-46 \mathrm{v}$,

33 Ibid, 3ov. $-3 \mathrm{I}$.

34 Ibid. $45 \mathrm{v} \cdot-46 \mathrm{v}$.

35 Luque a la audiencia. Patronato, 232, ramo I, I-6v. 
tector que manifestó ante la audiencia le hacía especialmente digno de crédito a los ojos de los magistrados.

La acusación de Luque contra los capitanes alude a los malos tratamientos a los indios, a que no pagan el trabajo de éstos, a que los someten a vejaciones en los pueblos y les toman cosas y bestias que no devuelven, habiendo sido inútiles las quejas del misionero al alcalde mayor. "Asimismo me querello de una imposición que tienen los dichos capitanes de dicho presidio en que les siembren dos pueblos una milpa cada uno y con dos indios cada semana sin paga ni de comer, diciendo que son encomiendas antiguas". Luque declaró haber ido a Parral, y que el gobernador le había entregado una real cédula de r67o sobre el trabajo de los naturales, y él la hizo pregonar: pero que el capitán dijo que aquello no: iba con él ni con los soldados. En consecuencia, este año se habían hecho las milpas lo mismo que antes, y aun con más rigor, amenazando el capitán con el bramadero a los gobernadores de los pueblos si salían de lo que él les ordenaba, sacando indios para su servicio y el de los soldados con sus sellos o mandamientos. Cuando se pagara a los indios según arancel dado por el alcalde mayor, los indios se verían sujetos al mismo trato que los soldados por parte del capitán, pues éste pagaba a unos y otros con géneros al quíntuplo de su valor, y así se hacían las compras a los naturales.i

Sigue la segunda parte del pedimento de Luque. Según dice, los indios van abandonando los pueblos "en cuatro ríos que tengo a mi cargo, que es jurisdicción de dicha villa de Sinaloa... por trabajo que les dan: sus Padres ministros en sembrar tantas cantidades de maíces, frijol, algodones... por el mucho interés que se les sigue a los Padres, no dejando en su libertad, tratándolos más que esclavos... sin pagarles su trabajo ... son domadores... arrieros... vinateros... meleros... esclavos, pues trabajan de noche y de día sin pagarles su trabajo". Con su mal estilo Luque sigue representando los malos tratos de algún Padre a sus naturales: al gobernador, un alcalde y un topil de Mocorito los azotaron y tusaron 
- -esto es, cortaron el cabello-y a uno le dijeron: "anda a tu alcalde mayor y capitán protector que os quite los azotes, que si se ofrece también los azotaremos".

Según Luque, no había para los indios más jueces que Jos Padres; ponían éstos gobernadores a su voluntad, buscalban sus particulares intereses, se desentendían: de los deberes de su ministerio, y habían dado lugar a que los achires se fuesen al monte. Los indios pedían pagar tributo, y el protector pedía que se pusiese remedio y se hiciese extensivo a Sonora, donde había aún mayo: desorden por ser mayores las siembras, habiendo partido doncle más de cuatrocientas mujeres molían trigo en sus metates. Con esto juntaban los Padres muchas cantidades de platas, por ser el género de más gasto y con que tenían tratos muy gruesos. Solicitaba finalmente Luque la protección de la audiencia, diciendo que los misioneros eran "muy perseguidores".

E1 I6 de noviembre de 1672 , la audiencia ${ }^{36}$ hizo pasar esta representación de Luque con los recaudos que mostraba -su título de protector y las cartas del Padre Cortés, fundamentalmente- al fiscal Haro y Monterroso, y éste dictaminó ser la materia "grave y secreta" y que se debía recibir la información de los tres indios, con dos intérpretes, por el oidor semanero. 37 Así empezó don Tomás Pizarro Cortés a recibir las declaraciones del indio Juan Bautista, que había sido gobernador del pueblo de Mocorito, y al primer día suspendió Pizarro el interrogatorio para pedir a la audiencia se reconociese la petición de Luque por comprenderse en la información sumaria los excesos de los miembros de la Compañía de Jesús, 38 "y habiéndose visto y ponderado - en la audiencia - la gravedad de los puntos que contiene, y que viendo si esto es conveniente al servicio de Dios y de S. M. el aplicarles el remedio que hubiese lugar, mandaron que dicho señor oidor prosiga en dicha información sin omitir ningún punto de los que

36 Tbid. $6 \mathrm{v},-7$.

37 Ibid. 7 .

38 Ibid. $7 \mathrm{v},-\mathrm{I} 2 \mathrm{v}$. 
en la petición se expresan, para en vista de ella dar cuenta a $S_{\mathfrak{}}$ Santidad, al rey nuestro señor en su Real Consejo de Indias, y para los más efectos que convengan conforme a derecho y cédulas del rey". 39

Prosiguió, pues, hasta el I4 de diciembre de 1672 , la deposición de Juan Bautista, de Martín Juárez y de Diego Martín, quienes citaron por su nombres a los Padres Francisco de Sepúlveda, Domingo Treto, Pedro de Amaya y Juan de Anchieta. Al parecer eran especialmente sensibles a la vista de los ganados mayor $y$ menor, mular y caballar, que los Padres tenían, y a las recuas con que trajinaban los granos para llevarlos a vender, y atnque ellos recurrían en sus quejas al alcalde mayor, créan en la superior autoridad que a los Padres daba el poder de excomunión. Así, los Padres quitaban a cualquier alcalde indio que no cuidase de enviarles al Colegio de Sinaloa el zacate, la leña, etc., aunque estuviese elegido por los pueblos y confirmado por el justicia mayor. Como los Padres disponían libremente de tode, los indios se quejan de cualquier disminución del número de candeleros o de cálices de las iglesias de sus pueblos _ - pues esto lo consideraban como propio- 10 mismo que de la venta de parte de los ganados de sus cofradías, siendo ésta la única noticia que nos llega de que los naturales de Mocorito tuviesen reses propias, aunque fuese como bienes de comunidad bajo la forma de cofradías. 40

Poco más añaden los indios, salvo algunas apreciaciones de las diferencias de precios de los artículos entre Guadalajara y la tienda del capitán de Sinaloa. Con esto, la primera piedra había sido lanzada. A la audiencia sólo le tocaba actuar con discreción en un astrnto de cuyo conocimiento no podía inhibirse.

39 Auto de 9 diciembre I672. Ibid. 12v.-13.

40 Ibid. 8v.-I $2 v$, y I3v. $-36 v$. 


\section{LA ACTUACIÓN DEL FISCAL Y LA REAL PROVISIÓN}

DE 24 DE DICIEMBRE DE 1672

Concluída de recibir la información de los mocoritos pasú el expediente, según los trámites usuales, a manos del fiscal, que el I $S$ de diciembre elevaba su escrito a la audiencia, ${ }^{4}$ dando por bastantemente justificada la demanda de Luque y los indios, y estableciendo dos cosas de interés para la continuación del asunto las determinaciones de la audiencia se harán extensivas a Sonora; se tratará con separación lo que afecta a los misioneros: "no es bien se halle mezclado lo demás que contiene este expediente que es tan secreto y conviene que ande aparte".

Por lo tocante al presidio, "la audiencia tiene jurisdicción privativa para castigar a todos los capitanes y militares que proveen en la Vizcaya y Galicia los señores virreyes", y así se deber mandar prender a Ramírez de Castro, con real provisión: para que se embarguen sus bienes en Sinaloa. El presidio, con sus crecidas dotaciones de salarios, no tenía por qué ser sustentado con el trabajo de los indios, o bien a éstos había que pagarles según la última cédula real que prohibía los servicios personales de leña, pescado, zacate, maíz, trigo, algodón, ni obrajes mayores ni menores, ni guardas de ganados, ni arrieros. Los indios debían percibir dos reales y medio por día por su trabajo, sin cue se permitiesen servicios por ningún pretexto a los alcaldes mayores, ni a los doctrineros seculares ni regulares, haciéndose a los primeros serio encargo para que lo cuidasen así, recurriendo si hiciese falta a la audiencia, y procurando al mismo tiempo que los indios sembrasen sus milpas de comunidad y una fanega a lo menos cada indio pari sí y su familia. "Y de lo que se proveyere se despachen dos provisiones, una para el alcalde mayor de Sonora y otra para el de Sinaloa".

Aquí concluye el primer punto del expediente según el fiscal,

$4 \mathrm{I}$ Ibid. $36 \mathrm{v} \cdot-42 \mathrm{v}$. 
que pide ahora que lo que sigue se aparte en expediente distinto, y continúa con estas sorprendentes palabras: 42 " $Y$ en cuanto a las molestias que padecen los indios de dichas provincias de los Padres doctrineros y tributos que ofrecen pagar a S. M. porque se les libre de ellos, considerando que las provisiones que se deban de despachar en el punto primero en que se manda poner en libertad a los indios y librarlos del servicio personal sólo servirán para que vayan con algún despacho de la audiencia, pero no tendrán efecto, como no lo han tenido las cédulas del real patronato, materia más escrupulosa, ni la ejecutoria de los diezmos que se despachó en el Real Consejo, porque los alcaldes mayores no tienen fuerzas, por estar más de trescientas leguas apartados de esta audiencia y más de doscientas del Parral, donde reside el gobernador de la Vizcaya, de cuyo distrito son dichas provincias, y que los Padres de la Compañia son muchos, y muchísimos los indios que tienen sujetos, y que todos los doctrineros o misioneros a los indios de su doctrina o misión, con pretexto de que son incapaces les hacen trabajar a unos en la labranza, a otros en crianza, a otros en obrajes, y ai otros en otros ministerios sin pagarles jornales, dándoles como les dan ración a todos los indios como si fueran sus criados, y aunque algunos Padres de la Compañía de dichas misiones que proceden apostólicamente todos los frutos que cogen del trabajo de los indios de su doctrina lo gastan en los mismos indios y en el culto divino, otros y los más lo emplean en otros fines muy apartados de su instituto, $y$ séase el fin que quisieren esto repugna a la ley natural que prohibe hacer trabajar al libre o distribuirle o disponer de su jornal contra su voluntad, y a tantas cédulas que tanto encargan la libertad de los indios e impiden el servicio personal".

Del mismo modo repugna al fiscal que las indias tengan que moler el trigo a mano, y supone que los provinciales de la Compañía no ponen remedio por razón de la distancia a que se encuentran.

42 Todos los subrayados son nuestros. 
"Y aunque todo lo referido es público, sin embargo, para dar cuenta y consultar al Consejo lo que pareciere más conveniente sin poner la materia en téminos de que sucedan los mismos escándalos que sucedieron en la provincia del Paraguay, parece que además de la información que está hecha se despache comisión para que el alcalcle mayor de Sinaloa la haga de los puntos siguientes, sin pasar a más, por conservar a la Compañía en su buen crédito, y todo con testigos españoles o los más".

Las cinco preguntas, en extracto, expresan lo siguiente: 1) Si es cierto que las provincias de Sonora y Sinaloa tienen más de sesenta y dos Padres de la Compañía de Jesús que administran ciento diecisiete pueblos y en ellos a $51.9 S_{4}$ indios matriculados, todos reducidos a pueblos, unos de más de cien años a esta parte, otros sesenta y el que menos cuarenta años. 2) Que indique cućntos de estos Padres son extranjeros italianos, ingleses, franceses, alemanes, portugueses, o de cualquier otra nación que no sea de Castilla y León. 3) Averiguará que vecindad tienen de españoles las villas de Sinaloa y Sonora, y qué otras poblaciones de españoles y reales de minas hay en las dos provincias. 4) Si los Padres hacen trabajar a indios e indias sin darles jornal y sólo les dan ración cle carne y maíz y alguna ropa para vestir según la calidad del indio y la familia que tiene. 5) Si es verdad que los dichos doctrineros tienen asimismo el gobierno temporal de los indios, eligiendo alcaldes y gobernadores sin que éstos los confirmen los alcaldes mayores, ni les den lugar a que se entrometan en ello.

Concluye Haro pidiendo se ordene al justicia de Sinaloa que proteja a los tres mocoritos que vinieron a declarar y que se confirme el título de protector a Luque.

Dos días después del pedimento de Haro y Monterroso, en 20 de diciembre de 1672 , la audiencia acordaba por tres autos distintos despachar real provisión para que se presentase ante ella Ramírez de Castro, procediéndose a prenderlo en caso contrario y 
que se separasen los autos de la manera pedida por el fiscal; 43 segunda provisión para que los alcaldes mayores de Sonora y Sinaloa amparasen y pusiesen en libertad a los indios, para que nadie les hiciese trabajar contra su voluntad, insertándose en ella las cédulas contra los servicios personales, ordenándose a los justicias enviasen original todo lo que actuasen con este motivo, y que amparasen a Luque y a los tres indios; 44 la tercera real provisión| debía dirigirse al capitán. Andrés González Rodero, vecino de la villa de San Niguel de Culiacán, a quien se encomienda reciba la sumaria de los cinco puntos propuestos por el fiscal, "y la remita original con persona de toda seguridad, de manera que no corra riesgo en el camino, y dicho capitán Andrés González Rodero informará a esta real audiencia lo que sintiere y entendiere sobre cada punto". 45

De las tres reales provisiones que debieron, pues, expedirse sólo nos ha llegado la prevista por el segundo anto. De la dirigida a González Rodero, cuyas resultas debían ser de extraordinario interés para nosotros, nada sabemos. La real provisión de 24 de diciembre de 1672 que da lugar a todas las polémicas que a continuación se producen - y de cuya utilidad, ya se ha visto, nada esperaba el fiscal - transcribe el texto del escrito de Luque hasta la relación de los diversos trabajos realizados por los indios bajo el gobierno de los misioneros, y narra los trámites siguientes del asunto hasta el auto que aprueba la proposición del fiscal, insertando luego las reales cédulas de 7 de junio de I62 I y 2 I de junio de 1662 que prohiben los servicios personales, y con la orden de poner en libertad a los indios e indias sin que nadie les hiciese trabajar contra su voluntad pasó a manos de los alcaldes mayores. ${ }^{6} 6$

43 Ibid. $42 \mathrm{v} \cdot-43 \mathrm{v}$.

44 Ibid. $43 \mathrm{v},-44 \mathrm{v}$.

45 Ibid. $44 v,-46 \mathrm{v}, \mathrm{La}$ separación de expedientes con mutilación de textos se llevó efectivamente a cabo, según puede verse en Patronato, 232, ramo 2.", 2-21. 46 Patronato, 232, ramo $10^{\circ}, 167-176 \mathrm{v}$. 


\section{Estalla la tormenta en Sinaloa}

A mediados de abril de I673 dio don Miguel Calderón y Ojeda, alcalde mayor de Sinaloa, su obedecimiento a la real provisión de la audiencia que le presentó Luque, "sobre que se pongan en libertad los indios e indias de dicha provincia". La besó y puso sobre su cabeza, "y despachó sus mandamientos a los pueblos del río de esta villa y a demás vecinos para que se hallasen a su publicación, la cual se hizo el día domingo que se contaron dieciséis de este presente mes, después de misa mayor, en voz alta de pregonero, siendo presentes los gobernadores y algunos más indios de dicho pueblo y vecinos de esta villa".

Verificada la publicación, se retiró Calderón a la plaza, y "al tiempo y cuando dicho alcalde mayor estaba en las casas de su morada dándoles a entender a los gobernadores de dichos pueblos lo que S. M. mandaba, llegó el Padre Pedro de Maya de la Conpañía de Jesús, vicerrector del Colegio de esta villa, el cual dijo que venía en nombre de su sagrada religión a obedecer los mandamientos de S. M., pero que en cuanto a su cumplimiento cesase en él, porque habían sus paternidades de proseguir como de antes, porque tenía su sagrada religión que informar a su alteza (la audiencia), y que en el interin no le parase perjuicio contra las falsedades que Francisco de Luque había informado, de que se les seguía grave daño a su sagrada religión, a que le respondió dicho alcalde mayor hablase por escrito su paternidad, que se le gyturdaría justicia, y que mirase su paternidad lo que hacía, en que le era fuerza dar cuenta a S. A., pues con eso cumplía con los mandatos de S. M." 47 Estaban a estos lances presentes el alcalde ordinario de la villa, capitán Pedro Barcelón, y el alférez nayor y regiclo: del primer voto, capitán don José Gómez, que como era usual habían pasado hasta las casas reales haciendo corte al justicia mayor. Muchos otros vecinos estaban a las puertas de las casas, y fueron

47 Auto de Calderón, Sinaloa, I7 abril I673. Patronato, 232, ramo 2. ${ }^{\circ}, 62-63$ ․ 
testigos de lo ocurrido. ${ }^{48}$ El Padre Maya se volvió al Colegio y 110 reaparece hasta diez días más tarde. Aquel mismo día el cabildo de la villa hizo presente por escrito al capitán Calderón que aunque en las reales cédulas insertas en la provisión se estipulaba se pagase dos reales y medio a los indios por día de trabajo, y que sólo trabajasen por esta paga los que voluntariamente se prestasen a ello, se continuasen los repartimientos de indios, por no haber otras gentes de que poderse valer para las faenas del campo o las construcciones de las casas, y que la remuneración se fijase en un real diario más la comida, "pues a Vmd. le consta la suma pobreza de esta tierra y poco trabajo de los indios, y que los bastimentos son tan caros que no hay indio que no coma de real y medio para arriba cada día, y aunque se le diese los dos reales y medio con cargo de que de ello se sustentaran, no fuera posible el poderlo conseguir por ser conto es la tierra incómoda para poder comprar el indio la comida". Alegaban los vecinos que por el gobernador de Nueva Vizcaya se había ordenado se pagase un real en plata, y que el propio Calderón había admitido en los aranceles que el pago fuese en ropa, "por haber reconocido que no hay real ni plata en esta provincia, ni aunque se le diera a los indios no lo habían de recibir". Calderón se limitó a disponer la remisión de este escrito a la audiencia. 49

A continuación el alcalde mayor consideró oportuno salir a la visita de los pueblos del río de Petatlán, para dar todo cumplimiento a la real provisión, y así el I8 de abril salió a Bamoa, regresando a la villa; el 20 lo hallamos en Nío; el 23, en Guazave, y el 24 en Tamazula. En todos estos lugares procedió Calderón a numerar las familias de indios de que se componían y a dar la libertad a los individuos que se consideraban criados o sirvientes del misionero: mayordomos, vaqueros, cabreros, jaboneros, cargadores, fiscales, topiles, sacristanes, pajes, cantores, cocineros y

48 Información de testigos recibida por Calderón, ibid. 63v.-66v,

49 Ibid. $66 \mathrm{v} .-68 \mathrm{v}$. 
guardas de milpas. Lnego les daba a todos el tlatole, "así en castilla cono en su lengua", por medio del intérprete José L_ugo, del contenido de la provisión, y les lacía elegir nuevos gobernaldores, a los que Calderón expedía los correspondientes títulos. La visita no quedó en esto solo, porque el 24 de abril presentaron al alcalde mayor los indios de Tanlazula un escrito de acusación de su misionero y seis días después imitaban el gesto los de Guazave. Todavía el 4 de mayo se presentó nuevo papel de Tamazula. Pero estas diligencias no condujeron a ningún resultado, y en cambio, al mismo tiempo, los jesuitas preparaban la réplica. ${ }^{50}$

El 24 de abril precisamente, en el Fuerte de Montesclaros, el visitador de las misiones, P. Alvaro Flores de Sierra, daba su poder al P. Bernabé Francisco Gutiérrez para actuar judicialmente en representación de todos los misioneros de Sonora y Sinaloa, 5: y al día siguiente, a petición del mismo visitador, el capitán Miguel de la Vega, teniente de alcalde mayor y capitán a guerra del Fuerte estimaba oportuno certificar "como nacido y criado en esta provincia" que los Padres daban siempre buen trato a los indios, sin someterlos a esclavitud ni tequios continuos, empleándolos sólo en ocasiones para arreglar las iglesias y sus casas de tierra, y dándoles entonces carne y maíz en abundancia para su sustento; dice Vega que los Paclres, por lo común, preferían valerse de otras personas; qute sus semillas se gastan en socorro de los indios, y que si queda algo se invierte, como las limosnas, en adornar la iglesia.

El teniente de alcalde continúa rebatiendo lo dicho por Lucue -el P. Flores debía estar bien informado-, diciendo haber visto cómo eran socorridos los indios en los partidos de Toro y Vaca. Sólo en Toro se les han dado más de doscientos setenta reses, habiendo habido cosecha en el partido de apenas doscientas fanegas de maíz y de cuarenta o cincuenta de trigo. Los Padres dan

5.0 Ibid. $46 \mathrm{v} .-50,58-6$ Iv

51 Ibid. 72. 
mucho más de lo que merece el trabajo de los indios, y cuando los ocupan en algo que paréca 110 ser de su obligación - -aunque redunde en beneficio de ellos-, les pagan y mantienen.

Nunca ha visto Vega abundancia de harina en los reales de minas. En Sonora, donde hay más trigo que aquí, tienen los Padres tres o cuatro tahonas que bastan para aprovisionarlos sin que las indias tengan que moler. En Sinaloa no sabe que nunca se haya molido una carga de harina para vender, sino sólo lo que los Padres necesitan para su sustento, que es bien poco, "pues con dos almudes de trigo molido entre cuatro o seis indias, comiéndose ellas parte de él, tiene un religioso pan para una semana y mucho para muchos más días".

Concluye el teniente del Fuerte aludiendo a las continuas conversiones de gentiles que todavía se realizaban en aquella región por parte de la sierra de los Tubares. ${ }^{5} \mathbf{z}$

E1 26 de abril, en fin, daba comienzo el P. Maya a la reclamación por escrito que tenía pendiente desde el I6.53 Maya, que pasa a indicar motivaciones en la conducta del justicia y a combatirlo, empieza diciendo "que luego que fue pregonada una provisión real de la real audiencia de Guadalajara, por lo que a los de la Compañía de Jesús ministros de doctrina de esta provincia de Sinaloa tocaba o podía tocar, ante Vmd. y testigos di el obedecimiento y dije que en cuanto al cumplimiento de algunas cosas tenía la Compañía de Jesús que informar, y que Vmd. no dijese a los indios cosa alguna de donde se pudiese originar poco respeto y obediencia a sus ministros, por ser gente nueva y deseosa de vivir a sus anchas y costumbres antiguas". También le pidió cesase en cualquier diligencia que pudiera tocar el nombre y crédito de la Compañía: "y no obstante todo esto, llevado Vmd. del mal afecto y enemistad que tiene a mi sagrada religión y a sus religiosos, no contento con haber llamado a esta villa a los indios

52 Ibid. $68 \mathrm{v} \cdot-72$.

53 Ibid. $50,5 \mathrm{I}$. 
de este río para el día del pregón de dicha provisión real, y dícholes lo que contenía la provisión real y otras muchas cosas que no están ni se mandan en dicha provisión: real, ha ido Vmd. a algunos pueblos de este río con título de visita a dar libertad a los indios, como ha dicho Vmd. quizá para darle más fuerza a la falsedad con que Francisco de Luque fue a la real audiencia exponiendo de los religiosos que tienen esclavos a los indios, siendo así que ellos sirven con toda voluntad por ver el desinterés con que los de la Compañía los administran". Asegura el P. Moya que ahora mutchos indios han quedado inquietos y otros escandalizados, y que Calderón dijo que la provisión tocaba a los Padres y al capitán, y no a los vecinos, "que arguye su mal afecto de Vmd.", y sus últimas palabras son: "recuso a Vmd. por enemigo declarado y apasionado contra la Compañía de Jesús y sus religiosos".

Admitiendo el pedimento de Maya, y teniendo que darse por recusado, hubo de proceder Calderón a nombrar juez acompañado para las causas que se of recieren tocantes a la Compañía de Jesís. nombrando para esta función al alcalde ordinario Barcelón, 54 y después, para hacer frente a las imputaciones del jesuita, pasó a asentar con declaraciones de testigos que siempre había declarado comprendidos en la provisión a los vecinos, como lo prueba el hecho de que éstos presentasen inmediatamente un escrito para modificar las condiciones; otros dos testigos informarían de cómo el P. Gutiérrez había abierto en el Colegio una carta de Luque a Calderón en que aquél advertía a éste los muchos enemigos que habría de tener de resultas de su gestión en Guadalajara; los testigos de la visita a su vez habían de declarar qué tlatoles dio él a los indios, y certificarían la autenticidad del primer papel de los de Tamazt1la - único hasta entonces recibido. Por lo demás, Calderón afirmaba que hasta el tiempo en que Luque fue a la audiencia le estuvieron comunicando los Padres, y carteándose y escribiendo cartas al gobernador de la Vizcaya diciendo que él tenía méritos para

54 Ibid. $5^{\mathrm{I}-52}$. 
cualquier oficio y que debía ser puesto en estatua en el pueblo de Tehueco - extremos éstos bastante bien probados en la mism: correspondencia del P. Cortés con Luque. Finalmente, "para que los señores de dicha real audiencia reconozcan quién perturba el cumplimiento de la real provisión y cédulas de S. M. y atendiendo al mucho ruido que dichos Padres de la Compañía han hecho juntándose $\mathrm{y}$ congregándose en este Colegio y dando a entender a la gente de esta tierra que ellos pueden mucho y que se ha de huir dicho alcalde mayor, dijo que cesaba y cesó en dicha visita, hasta tanto que S. A. de todo punto declare el servicio que cada Padre ha de tener y la obligación del indio". 55 Hízose, pues: la información de testigos a satisfacción del alcalde mayor ante Barcelón, ${ }^{6}$ y unos días más tarde compareció ante éste el Padre Maya para pedir se le recibiese a él otra de los testigos que presentaría sobre los antecedentes del delator Luque, en tres puntos, y sobre el trato que los Padres daban a los indios, si daban lugar a que éstos huyesen, y si no los sustentaban en hambres y enfermedades, 57 y en efecto, en dos días presentó el jesuita cinco testigos suspendiendo el continuar haciéndolo para aprovechar la primera ocasión de enviar la documentación a Guadalajara, aunque sin abstenerse de recabar de Barcelón certificaciones de que estaba dispuesto a seguir presentando testigos de lo más granado de la villa, de que había dado el obedecimiento el día que se presentó la real provisión, y de que ese mismo día nombró Calderón gobernador a Juan, uno de los mocoritos que habían acompañado a Luque a la audiencia. 58

\section{LA AUDIENCIA MANTIENE SU POSTURA}

E1 I3 de mayo de 1673 hizo remisión el alcalde mayor de Sinaloa a la audiencia de lo actuado, y al parecer cesan con esto

55 Auto de Calderón, Sinaloa, 29 abril I673. Ibid. 52-53v.

56 Ibid. $53 \mathrm{v},-58$.

57 Pedimento de 2 mayo 1673 . Ibid. 73v.-74.

58 Ibid. $74-84$. 
las diligencias que venían practicándose en la villa en tensión. 59 El astunto se traslada a Guadalajara, donde el apoderado de las misiones, P. Gutiérrez, presenta ahora una petición en que, aludiendo a la gestión de Luque, "protector que dijo ser de los naturales de la provincia de Sinaloa, mestizo", y para rechazar la real provisión emitida en consecuencia, presenta certificación dada por Miguel de la Vega, en la cual consta el buen trato dado a los indios, que Luque abultó las cosechas, que se paga a los arrieros y que los Padres sólo se ocupan en su ministerio. Desatutoriza Gutiérrez a Luque haciendo relación de su mala vida y de su fuga y excomunión, y de que "hasta el día de hoy anda fugitivo", y naturalmente presenta en su apoyo la información que el P. Maya hizo dar ante Barcelón, que en su primera parte favorece además a los Padres, más la carta de Luque a Calderón, "que por accidente llegó a mi poder", y dice ser notoria la enemiga del segrundo a la Compañía, que le lleva a librar a los vecinos del pago a los indios, manifestando además - los Padres no olvidaban nada- que siendo Calderón casado en Castilla, y estando aquí ausente de su esposa, se le debía hacer volver a la península.

Pide el Padre Gutiérrez a la audiencia que se recojan las reales provisiones y se suspenda su efecto por ahora, hasta que se decida en vista de lo que deben informar los alcaldes mayores, despachándose para esto nueva provisión a justicia que no sea Calderón. En todo caso, la audiencia debía aclarar a qué indios se debía pagar y por qué concepto. 6.0

A la vista de este escrito y sus documentos anejos, el fiscal Haro propone ${ }^{6 I}$ la devolución de la causa de concubinato contra Luque a su juez, para su fenecimiento; y que se ordene al gobernador de Nueva Vizcaya nombre otro alcalde mayor en Sinaloa, para que Calderón regrese a España. Son clos victorias de los

59 Ibid. 6 I v. -62 y $68 \mathrm{v}$.

60 Relación del P. Gutiérrez, Iz junio r673. Ibid. 95-103.

6 I Pedimento fiscal de 23 junio 1673. Ibid. 103-106. Los subrayados son nuestros. 
Padres, sin duda, pero que no afectan al fondo del problema. En cuanto a la pretensión de los vecinos de Sinaloa, remitida por. Calderón, "respecto de que en esta Ciudad se dan salarios a los labradores sólo por el tiempo de la siembra y por el tiempo de la siega, se debe mandar lo mismo para dichas provincias, con calidad que no los ocupen más tiempo, ni más días, ni en otros ministerios, dándoles de comer y el jornal de cada día el que tasare la audiencia según la calidad de aquella provincia".

"Que se despache sobrecarta para que luego y sin dilación se publique y ejecute y que no se oiga ni se forme litigio sobre ello, porque no es ni puede ser contra la Compañía ni sus misioneros, a los cuales no les toca el gobierno corporal de los indios, que están a cargo del gobernador de la Vizcaya, y de los alcaldes mayores que nombran, cuidar en común y en particular de los indios, de sus sementeras y milpas, y el hacerles que trabajen y no vivan holgazanes y el castigarlos si no lo hicieren, y si les sobra algo a los indios de la milpa de comunidad, no le toca al doctrinero el distribuirlo ni gastarlo, aunque sea en el culto divino, pues las reales cédulas y su instituto les prohibe la administración de lo temporal, y si los misioneros o doctrineros necesitan de indios para sus milpas $u$ otros ministerios, no lo han de hacer, ni pueden hacerlo de su autoridad sin pedirlos al gobernador como to hacen los demás vecinos, y entonces pagándoles su jornal, pues S. M. les paga el estipendio de sus reales cajas con calidad expresa de que los indios no les hagan servicio, y considerando que la provincia de Sonora es la más apartada y que confina con indios gentiles, los cuales viendo que a los reducidos se les hace buen tratamiento y que en todo son tratados como libres y que a ninguno hacen servicio, con facilidad se reducirán al gremio de la Iglesia, y aunque se debe presumir del santo celo de los Padres de la Compañía que tratan a los indios con el amor de hijos y que por excusar su flojedad los ocupan en diferentes ministerios con que consiguen que no haya embriaguez y que se mantenga y conserven, alimen- 
tándolos como los alimentan, y el residuo y lo que sobra lo gasten en el adorno de los templos y cura de los enfermos, todavía pesa más el que se ejecute lo que S. M. manda en sus reales cédulas. pues en todos tiempos se han reconocido que es mejor quitar a los indios de la carga del servicio personal y que su gobiemo temporal corra por sus justicias, y así no se debe formar litigio sobre esto, sino sólo que se ejecuten las reales cédulas".

El dictamen del fiscal, a un tiempo discreto y certero, es, no se olvide, el del mismo hombre que no creía seis meses antes gute la real provisión fuese a dar ningún fruto, porque los Padres lo impedirían. Ahora termina diciendo que no sería justo que al misionero tuviese que pagar a los indios del servicio de la iglesia : el gobernador de Nueva Vizcaya podría determinar cuántos requerían las atenciones de cada templo, y a éstos los pagaría la comunidad de los indios "como se hace en La Galicia".

Llegado este momento, la audiencia decidió pasar traslaclo del pedimento fiscal al apoderado de las misiones, que lo era ya, por sustitución del P. Gutiérrez, Juan Pacheco de Solís, quien respondiendo con suma brevedad e insistiendo en las demandas de Gutiérrez, añade, ${ }^{62}$ que se reduzca el salario fijado a los indios, y que no sea en reales; que se reconozca el buen trato, pagas y cariño de los Padres a los naturales, ya probados en los autos "que pasa los términos de la presunción"; y que se tache del escrito de Luque la acusación contra los misioneros. A continulición fragua Pacheco un verdadero sofisma que es al mismo tiempo una columna contra sus defendidos: reconociendo que no toca a los Padres la administración temporal, dice que "en ella nunca se han metido, por no ser de obligación", que los naturales no tienen milpas de comunidad "por falta de tierras, y por esto les es de conveniencia el servicio que han hecho voluntario a la Compañía... y no teniendo milpas de comunidad, no se pueden haber ocupado los doctrineros en distribuir sus efectos", y asi sólo han

62 Ibid. 28 junio 1673 . 
repartido los propios bienes de la Compañía. El desgraciado pensamiento de Pacheco y de su sucesor jurídico Zabala, arranca de la idea de considerar toda la tierra de las provincias como propia de la Compañía - ¿ dónde están los títulos?-. Concluye haciendo presente que los servidores de las iglesias son, de ordinario, algunos huérfanos a quienes los misioneros adoctrinan, visten y sustentan, y no sería lógico que hubieran de pagarles; pidiendo al fin que se dé providencia que vuelva a la tranquilidad a los indios, y que su ejecución se cometa al alcalde ordinario de Sinaloa o a otra persona desinteresada y de buen celo.

Cuando Haro, a su vez, pasó la vista por el escrito que acabamos de extractar, se limitó a añadir : "El fiscal, afirmándose en lo que tiene dicho y alegado y negando la perjudicial, concluye sin embargo". ${ }^{63}$ Así, el 30 de junio de 1673 pudo la audiencia pedir los autos y el 18 de junio de 1673 siguiente prové́a uno mandando expedir real provisión para que nadie se sirviese de los indios sin pagarles a razón de dos tomines y medio cada día en época de cosecha, y el resto del tiempo a dos, "sin la comida, que no se ha de tener en cuenta", y en Sonora, por no haber dinero, en cosa que equivaliese según el uso corriente de aquella provincia. Los sirvientes de la iglesia - portero, campanero, sacristán y cantores- no percibirian salario, pues estas ocupaciones las desempeñaban todos los indios por turno. "Que estos autos - decide la audiencia- se recojan en el secreto del Acterdo, y lo acordado se someta la ejecución de lo contenido en este auto a Juan Francisco Maldonado, vecino de la provincia de Sonora, para que lo ejecute y le de a entender a los indios la obligación y reverencia que deben tener a sus doctrineros". 64

A este tenor se expidió efectivamente la real provisión y sobrecarta de 20 de julio de $1673^{65}$ que realmente afianza lo dispuesto en la de diciembre del año anterior sin desentonar en las

6328 julio 1673 . Ibid. III.

64 Ibid. III-II3.

65 Patronato, 232, ramo $30^{\circ}$, I-IIV. 
manifestaciones de respeto a la Compañía de Jesús y sus miembros, y sin dejar tampoco apuntar la visión del problema que mucho más claramente expone el fiscal. Su ejecución, en cambioi, encomendada a un adicto de los Padres, constituiría un triunfo de éstos en su afán de mantener el estado de cosas.

\section{LA POLÉmica sobre los indios EN SONORA}

El 20 de abril de I 673 obedecía la real provisión de 24 de diciembre anterior el alcalde mayor de Sonora, don Gregorio López. de Dicastillo y Aramburtu. Al día siguiente, primer domingo de Pascua del Espíritu Santo, a la salida de misa mayor, a la puerta de la iglesia del real de San Miguel, ante españoles, indios y gente latina, tenía lugar la publicación del documento, y el I I de junio lo hacía pregonar en el real de San Juan Bautista el teniente de alcalde mayor y capitán a guerra Juan de Grijalva, por voz del mulato Felipe de la Cruz. ${ }^{66}$

Al parecer, el efecto inmediato de la publicación en San Miguel consistió en una apreciable disminución de los bastimentos que habitualmente habían estado remitiendo al real las vecinas misiones y simultáneamente pedían los Padres abrir información, y en efecto, empezó a recibir declaraciones el alcalde mayor, preguntando a los vecinos si podían pasar sin los bastimentos de los $\mathrm{Pa}$ dres. Aquellos se apresuraban a responder que no, entendiéndose que los Padres manejaban las cosechas de los indios, cosa ajena a la voluntad del rey y al ministerio de los jesuitas. Ya anteriormente se habian hecho informaciones sobre que no se podía vivir en la provincia sin el anxilio de los Padres, y Dicastillo podía consultar los testimonios al respecto en el archivo de la alcaldía para tales diligencias - practicadas durante el gobierno de Pedro Francisco Sartillón - evitaban aludir a la causa de esa extraña dependencia de los reales de minas respecto de los misioneros. No nos

66 Patronato, 232, ramo I, I 76 v.-180v. 
han han llegado las informaciones recibidas en este momento por Dicastillo, pero él las cita al escribir al P. Marras pidiéndole no corte el suministro de mantenimientos. ${ }^{67}$

Casi un mes más tarde convocaba don Gregorio junta de los vecinos de San Miguel en su morada ${ }^{68}$ alegando que como los Padres tenían todos los mantenimientos y las tierras e indios, y como después de la publicación de la real provisión los Padres habían de jado de hacer sus ventas, por lo que faltaban harina y maiz, siendo ellos la causa de esta hambre, y que habiendo el Padre Marras suspendido las ventas después que él le escribió sobre el asunto, siendo el intento de todos que no hubiese más remedio que declarar que sin ellos no se podía vivir, como ya procuró probarlo años atrás el mismo Padre citado, era preciso que cada uno en la reunión convocada dijese lo que sentía en negocio y causa tan importante y grave, para que se eligiese y ejecutase el medio que más conviniese para el remedio de la necesidad comín.

Acudieron, en efecto, los vecinos e1 23 de junio a la junta y. comenzó Discatillo preguntando si había hambre, "habiendo habido muy pocos días antes del presente abundancia", y la causa de ello. Respondieron que se debía a que los Padres ya no enviaban los artículos de las misiones, y don Pedro de la Vega, vecino, dijo que habiendo ido él mismo, con plata, a buscar maíz entre los Padres, no se lo habían querido vender como solían, ni se hallaba. Después leyó el alcalde el auto de convocatoria de la junta y pasó a preguntar su sentir a Sartillón, quien se limitó a manifestar que siendo él alcalde mayor de Sonora se había hecho la ya conocida información para probar la utilidad de las ventas que hacían los Padres, y continuó luego diciendo muchas cosas en defensa de éstos. En su intervención pasỏ largo rato y la junta concluvó con la propuesta del bachiller Valdés, cura de los reales de San Juan y San 'Miguel, para que "por medios suaves se solicitasen los mantenimien-

67 Dicastillo al P. Marras. San Miquel, 28 mayo r673. Ibid., I3r-135.

68 Auto, San Miguel, 23 junio 1673. Ibid. I39-1 46. 
tos del dicho P. Daniel Angeto, que es el que siempre los ha vendido y vende para todo el abasto del real de San Mignel, y que yo el alcalde mayor escribiese en esta razón, de cuyo sentir fueron todos los de lá dicha junta". A continuación, el alcalde, el vicario y ocho vecinos acordaron "que en cualesquiera información que de parte de los dichos Padres y en su favor se hicieren en adelante en esta materia de bastimentos no es conveniente declare el dicho don Pedro Sartillón ni otros en este real de San Mignel, ni en el de Sán Juan, por ser notoriamente confidentes y parciales del dicho P. Daniel Angelo Marrás y de los clenás Pulres", y mandó Dicastillo unir al expediente las dos cartas que tenía escritas al Padre citado y la que ahora escribiría. 60

Ei 25 de junio, pues, escribió Dicastillo de nuevo al Paclie Marras dándole cuenta de lo acordado en la junta pública y previniéndole no dejase de enviar los bastimentos como hasta entonces, por medio del general Sartillón, al real, y a los mineros y haciendas, hasta que los indios sembrasen para sí mismos y empezasen a vender directanente al común. En cuanto a los mantenimientos, "muchas (veces) he visto y han visto todos que se los enviaba V. P. a su casa (de Sartillón) con la recua de la misión de Matape para que los vendiera". jo

Para entonces ya sabía Dicastillo que su sucesor don Domingo del Hoyo y Santayana estaba en Gtrazaras, viniendo a tomar posesión del mando cle la provincia, y cuando esto tuvo lugar, lo que hasta entonces había sido prácticamente monólogo de don Gregorio, pasó a convertirse en amplia polémica de creciente acritı1 pública.

El I 5 de julio, transcurridos tres meses de la publicación de la real provisión, presentaba el Br. Valdés ante Hoyo un pecli-

69 Ibid, I39-146. Son los firmantes del acterdo, con Dicastillo y el Br. Valdés, Juan Ignacio de Abreros, Juan Antonio de Echevarría, Pedro de Ibarra, don Gabriel Fontes de Espinosa, Nicolás de Valenzuela, Andrés de Acuña, don Juan Amatilla y José del Castillo.

$7^{0}$ Ibid. $135^{-1} 39$. 
mento ${ }^{71}$ para que aquélla, que sólo había sido dada a conocer a: los indios del real de San Miguel, de Tecoripa y de Matape, fuese pregonada en todos los partidos y misiones de Sonora. $Y$ pedía además que no se admitiese información alguna contraria a la aplicación de dicha real provisión sin que antes se le diese aviso a él y se citase al protector de los indios, para que éstos no quedasen indefensos. Floyo, que debía ser bastante ajeno a los contendientes de la cuestión, se avino a lo pedido por el vicario, invocando además la real cédula dirigida en 1672 a los prelados de Indias para que celasen no se gravase a los indios con servicios personales. "Saldré a la visita -dice el nuevo justicia- por todos los partidos de esta jurisdicción, no permitiendo en el interin se contravenga a dichas reales cédulas". ${ }^{72}$

Muy poco después se producía el primer conato de la contraofensiva de los Padres. El 22 de julio entregaban veinte vecinos de San Miguel al teniente de alcalde mayor Sierra un escrito declarando que aquél real se pobló con ayuda y fomento 73 de los jesuitas, y muy en particular del P. Marras, misionero de Matape y rector de la misión y colegio de San Francisco de Borja, "a quien según pública voz y fama se debe no sólo al haberse poblado, sino el haberse conservado siete años poco más o menos, habiendo acudido dicho Padre Rector, no sólo con los bastimentos que sobraban de su partido, sino con muchos otros que de varias $y$ muy remotas partes hacía conducir con mucha costa, sin más intereses que el socorro de los pobres y de muchos vecinos a quienes se repartían... al mismo precio que su $P$. Rector los compraba, de que se seguía no sólo el remedio de los pobles, sí también mucha utilidad al resto de dicho real, porque por esta causa no subían de precio los demás bastimentos que en él entraban, y esto es tanta verdad como pública voz que la "recua de los pobres", que así se llamaba la del dicho P. Rector Daniel Angelo de pocos días a esta parte ha

$7 \mathrm{I}$ Ibid. I 80-I $83 \mathrm{v}$.

72 Auto de Hoyo, San Juan, 17 julio 1673 . Tbid. 183v.-185.

73 Ibid. 203-206v. 
alzado la mano a dichos socorros $(y)$ se ha experinentado mucha necesidad en este real y ha legado a nuestra noticia que el clicho P. Rector ha dejado de hacemos el bien que solía por una voz que se ha esparcido por la provincia diciendo que los dichos Padres se han apoderado de los bastimentos y mantenimientos necesarios para la vida humana, que no dejan a los naturales en su libertad para sembrar y criar ganados para si y para vender a los españoles y que venden los ganados de los indios e impiden a los españoles las siembras y crias de ganado, a fin que el común compre a dichos Padres y que éstos sean dueños de la hambre o abundancia de la tierra".

El párrafo es, sin duda, mucho más elocuente de lo que sus antores pretendieron, $y$ las noticias que poco después stministrará Dicastillo arrojan sobre él y sobre la situación de Sonora vivisima luz que aclare, no ya el problema del indio, sino la vicla y las relaciones econónicas generales de todos los habitantes de la provincia. Los vecinos todavía añaden algunas consideraciones más: los indios - dicen- siembran para sí y venden a los rescatadores españoles en los valles de Cumpas, Oposura y otros; los indios no tienen ganados porque no se lo permite su pobreza, y por tánto tampoco pueden venderlos los Padres; hay en la provincia muchas estancias de ganado y sementeras de españoles, "los cuales venden en los reales de minas sus ganados y semillas, pero no con la conveniencia a que los Padres los dan, pues ha habido ocasiones que algunos seculares vendieron maíz una larga temporada seis, ocho, y diez pesos fanega, cuando el dicho P. Daniel Angelo Marras se lo daba a tres pesos". Por consiguiente los vecinos consideraban a los Padres merecedores del agradecimiento de sus superiores y del rey, y piden al teniente Juan de Sierra que autorice este infome con su certificación de lo expuesto por ellos.

Sierra, efectivamente, tras dar constancia de que los firmantes del anterior escrito eran vecinos del real de San Miguel, dueños de carboneras y mercaderes y aviadores de dichas haciendas y car- 
boneras, añade: "Y yo el dicho capitán Juan de Sierra, como vecino y minero de este dicho real, dueño de hacienda de sacar plata beneficio de fuego, digo, que debajo de juramento, que lo haré siempre que se ofreciere ante mi juez, como persona que soy de los primeros pobladores y descubridores de este dicho real, que todo lo que contiene este pedimento presentado por las personas que lo han firmado es cierto $\mathrm{y}$ verdadero, y digo lo mismo como vecino minero y como persona que tengo muchas y muy buenas noticias de lo bien que los Rdos PP. de la Conıañía de Jesís han obrado en servicio de ambas majestades, fomento de los reales de minas, socorro de todos los vecinos de esta provincia y los pobres de ella". Sierra da por falsa cualquier voz en contra de esta afirmación. I't

Después de los escritos hechos por los vecinos y del teniente de alcalde mayor de San Miguel, aparecen por fin ante Hoyo los Padres Juan de Betencourt, misionero de Babiacora y rector de la misión de San Francisco Javier, y Daniel Angelo Marras, misionero de Matape y rector de la misión y colegio de San Francisco de Borja, quienes en nombre propio y de los demás misioneros de la Compañía en la provincia únicamente piden al justicia que obligue a su antecesor a manifestar el auto de convocatoria de la junta que leyó a los vecinos de San Miguel, "porque dicho escrito no pueda en tiempo alguno perjudicar al crédito y buen nombre de nuestra sagrada religión ni a alguno de sus hijos". Conociéndolo podrán ellos alegar y pedir lo que convenga a su derecho. 75

\section{La estructura económico-social de Sonora}

A LA LUZ DE LA CONTROVERSIA

Con el pedimento de Betancourt y Marras de 28 de julio que acabamos de citar se abre por fin en Sonora el debate suscitado por la real provisión de diciembre de 1672 . Este debate dura prácticamente un mes, hasta el 26 de agosto siguiente en que Hoyo,

74 Ibid. $206 \mathrm{v} \cdot-207 \mathrm{v}$.

75 Ibid. $185-187$. 
que previanente se ha declarado juez incompetente en materia tan peigrosa, decide renitir el expediente a lá audiencia de Nueva Gálicia. En el intervalo se amontonan los escritos de una y otra parte, siendo de advertir como características del problema que en Sonora janás se discute - como habia ocurrido en Sinaloa-que los vecinos hayan de pagar el trabajo de los indios; y que casi desde el primer momento la polénica se hará enormemente personal, entre Dicastillo - que dice luchar por la interpretación correcta de los hechos visibles y por la aplicación estricta de la real previsión-y el P. Marras - quien descle principios de agosto aparece actuando solo y a quien Dicastillo presenta como defensor del lamentable estado de cosas, pero que por su purte dice no pretender cosa alguna contra las disposiciones del rey y de la audiencia.

Si los Parlies no hubiesen entrado en escena el 28 de julio con la mira de defender el crédito de la Compañía, tal vez nunca se hubieran producido los documentos que hoy polemos analizar para conocer la situación real, los grupos y los intereses de los pobladores de Sonora. En cuanto al desarrollo de la polémica, Dicastillo mantendrá siempre que los autos sobre la junta y real provisión los renitió a la audiencia por conducto del Br. Valdés - y en efecto, había enviado estos documentos a Guadalajara con carta fechada en 24 de junio anterior-, 76 y pasará desde el primer momento a la ofensiva acusando a los Padres de hacer trabajar sin paga a los indios para luego comerciar los frutos con los españoles, y de no dejar intervenir a los justicias en el gobierno de aquéllos. Ante esta actitud, el P. Daniel Angelo, llamando al auto de la junta libelo infamatorio y declarando al Br. Valdés no sólo incompetente, sino conocido émulo de los misioneros, pasó a cuterellarse en nombre de la Compañía contra don Domingo por calumniador. comminándole a declarar cuáles sean los reales de minas del distrito del real de San Miguel, qué haciendas habían aviado el P. Marras y los demás jesuitas y a qué mercaderes se remitían los basti-

76 Ibid, 130-I 31 . 
mentos; y pidiendo que esta querella y demanda se acumulase al juicio de residencia de Dicastillo. El ex-alcalde nayor no podía menos de ratificarse cada vez con mayor extensión en sus declaraciones, de palabra y por escrito, asegurando siempre: "mi intento no es, ni ha sido, ni me ha pasado ni pasa por la imaginación el desdorar en cosa alguna al dicho Padre ni a los denás hijos de tán santa religión y tan grande y grave como es la de la Compañía de Jesús", mientras que de sí mismo dice, que no teniéndose por sabio ni "estudiante", pero tampoco por bobo, que es "no sólo leal vasallo de S. M., q. D. g., sino de los que han nacido dentro de España y de conocida calidad en lo limpio y noble de mi sangre, y aunque esto es notorio, consta también de los papeles auténticos que en mi poder tengo". $77 \mathrm{El} \mathrm{P.} \mathrm{Marras} \mathrm{entonces} \mathrm{llegó} \mathrm{a} \mathrm{pedir} \mathrm{se}$ le recibiese información sobre un interrogatorio cuyas catorce preguntas - quitadas las generales del principio y fin son: 3) si es cierto que los Padres no cobran estipendios ni pensiones; 4) que atienden a los pasajeros que circulan por los caminos; 5 ) que abastecen a los soldados; 6) que pagan a sus sirvientes y arrieros; 7) que matan reses para sus indios los domingos y otros días de fiesta; 8) que socorren a los indios en sus necesidades todo el año; 9) que les dan semillas para que ellos siembren para sí; 10) que lo que los Padres obtienen de beneficio lo invierten en el culto divino; I I) que han formado capillas de música y enseñado cantores, etc. ; I2) que han proporcionado el fomento indispensable a los reales de minas; I3) que los naturales siembran trigo, maíz, y sus otras semillas; I4) que también se rescatan granos a los gentiles; I 5) que hay muchos labradores y ganaderos españoles; I6) que en caso de necesidad en el país, ellos hacen venir bastimentos incluso de otras lejanas provincias; 17 ) si es cierto que el P. Marras por sí solo abastece San Miguel. ${ }^{78}$

Hoyo llegó a admitir esta información, pero antes de que se

77 Ibid. $220-233$.

78 Ibid. 253-256. 
hiciese decidió, según propuso tenazmente Dicastilo, renitir todos los autos a Guadalajara, al tiempo que el P. Marras tachaba al cápitén protector Juan de Encinas - a quien Hoyo había citado para que estuviese presente a las declaraciones de los testigos- de ser "enunigo declarado del stisodicho y de los demás Padres misioneros de esta provincia, pues públicamente dijo en el Real de Sar Miguel delante del general don Pedro Francisco Sartillón y del Br. José Coronado vicario actual del dicho real de San Mighel, con voto que echó, diciendo voto a Dios que el rey mestro señor no es dueño de esta tierra, sino es los Padres Teatinos y que daré doscientas puñaladas al P. Daniel Angelo Marras", 79

En fin, después de resuelta la remisión de todo a la audiencia, procedió Dicastillo a elaborar un extenso inforne dirigido a este tribunal, en el que hace ver lo ourrido en Sonora entre misioneros, españoles e indios; ${ }^{\circ}$ por supuesto que también el nisionero de Matape recurrió a eseribir a Haro, e ignorando la mentalidad del fiscal asienta en su segunda carta: "según ni pobre juicio, juzgo que todo el alivio y consuelo de esta tierra pende del santo y cristiano celo de Vnud.". "s Puestos en movimiento los resortes de la Compañia, escriben algo desunés a Haro Juan de Sierra, Pedro Francisco Sartillón y Pedro de Camorlingo; ${ }^{8}$ y y aún más tarde seguirán las informaciones recibidas en México y Ostimuri, de que hablaremos a su tiempo.

Pero, ¿cuál es la fisonomía que nos muestra Sonora a través de las invectivas cambiadas entre los contendientes en la polémica sobre los indios? Las tierras eran todas, legalmente, de los indios y del rey. No debían haberse hecho muchas mercedes a españoles en los ctiarenta años de historia de la provincia. Sin embargo, los Padres las señoreaban todas de fucto. Algunos habían comprado

79 Ibid, $260-262 \mathrm{v}$.

So Dicastillo a la Audiencia, San Juan, I2 octubre 1673. Ibid, 46-127. Este es el principal informe de Dicastillo, al que aludimos en todo lo que sigue, salvo indicación ell contrario.

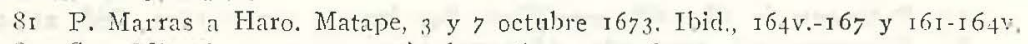
82 San Miguel, 10 y it noviembre 1673. I5I-16I. 
algún terreno para las misiones, no teniendo éstas licencia del rey para su fundación, ni hacienda ninguna, ni propios : así la de $\mathrm{Ma}$ tape tenía un corto sitio de tierra "que fue de los herederos de don Pedro de Perea, conquistador de Sonora" $8_{3}$ que el P. Daniel Angelo había adquirido para un sirviente suyo llamado Tomás. Pero lo importante era que, a través de los indios, los Padres eran dueños de todas las tierras útiles de la región, y que esto es cierto lo prueba, aún mejor que todo los alegatos de Dicastilla, una curiosa confusión producida al tratarse de estos puntos pocos meses más tarde. El I4 de febrero de I674 proveía la audiencia de Guadalajara un auto del tenor siguiente:

"Por cuanto de los autos que se han visto... se han reconocido muchos pleitos y disensiones que hay en las provincias de Sinaloa y Sonora entre los vecinos españoles e indios naturales de ellas sobre las tierras y repartimiento de ellas de que hay mucha confusión por ser nuevamente pobladas y por no estar repartidas en forma dispuesta por las reales ordenanzas se carece de los bastimentos de que necesitan para el sustento de sus pobladores $\mathrm{y}$ : convendrá muclio al servicio de S. M. que el maestre de campo don José García de Salcedo, caballero del hábito de Santiago, gobernador y capitán general de las provincias de la Nueva Vizcaya baje a dichas provincias y como quien tiene la cosa presente divida y reparta entre los vecinos españoles e indios las tierras quei le pareciere necesita cada uno conforme sus méritos, teniendo siempre consideración a dar a los naturales todas las que hubieren menester como esta audiencia lo espera lo hará conforme a sus buenas obligaciones. Mandaron que luego que se desembarazase de sus ocupaciones militares que tiene entre manos vaya a las dichas provincias de Sinaloa y Sonora a ejecutar lo contenido en este auto, dando cuenta a esta real audiencia de todo lo que obrarel para que la pueda pasar a S. M., y a su Real y Supremo Consejo de las Indias en la primera ocasión". 84

83 Pedimento de Dicastillo ante Hoyo, San Juan, 9 agosto 1673 . Ibid. 220-233.

84 Patronato, 232, ramo $3 \cdot^{\circ} 3,2 .^{2}$ parte, I-IV. 
En estos términos fue la real provisión despachadí por la andiencia en 20 de febrero de 1674 al gobernador det Parral, quien poco después escribió sobre ello al provincial de los jestitas de México, que lo era el P. Manuel de Artegra, diciéndole que pasaria a las alcalías costeras a repartir las tierras sin quitar a la Conpañía las que poseyese por merced real. Arteaga pone el grito en el cielo clamando gue la Conpañía no tiene merced especial para poseer esta o aquella tierra, este o aquel sitio: sólo se le dijo que entrara a la conversión del país, y sus miembros pasaron a él los primeros, mucho antes que crialfuier otro español, y vivieron durante años solos en las ratucherías y pueblo. Ahora, sigue el provincial, si García de Salcedo ha de obrar como dice, "bien puede $V$. S. desde luego demoler nuestras casas todas en aquellas misiones, talando las sementeras que hubiere, y sacar de la provincia los gamados todos que para su sustento y el de los indios, y aun para el de los misnos españoles han ido criando los Padres en algunas partes cómodas". ${ }^{85}$ Ante tan extraño alegato-qute nuestra terminantemente que las tiertas que las misiones poseyesen en Sonora las tenían sin concesión real--, se dirige García de Salcedo a la audiencia, respondiendo a la real provisión con estos no menos sorprendentes conceptos: "Teniendo restrelto... bajar a dichas provincias luego que pasen las aguas, he recibido carta adiunta, que remito a V. A. con ésta, del P. Provincial de la Compañía de Tesús, en que respondiendo a otra que le escribí sobre las materias convenientes al gobierno parece que en un párrafo de ella afirma que la Compañía tiene y posee tierras en aquellas provincias con el título de haber entrado los religiosos de la Compañía a convertir y predicar la fe a aquel gentilismo por mandato de S. M., y que tienen éste por bastante título para poseer las tierras y sitios de que gozan. Y si esto es como refiere el P. Provincial, tengo por vaga y supervacua mi visita y ida a aquellas partes, por

85 P. Arteaga a García de Salcedo, México, 28 abril I674. Ibid. Iv.-7. 
tener como tengo especial noticia de que es la mayor parte la que poseen los Padres". 86

Si Salcedo da como cierto que los misioneros tienen la mayor parte de las tierras, es claro que tal idea se fundamenta en el hecho de que ellos controlaban las de los indios, para labranzas - para pastos. La audiencia también debió entenderlo así después de leer la carta del gobernador y la anexa del Provincial, y decidió, pese a las instancias del fiscal, "que por ahora suspendían y suspendieron el que el gobernador de la Nueva Vizcaya pase a las provincias de Sinaloa y Sonora ínterin que se da ctrenta a S. M." 87 Ciertamente años después dispuso el Consejo de Indias que se 1levasen a cabo las oportunas averiguaciones sobre aquellas tierras y aguas, 88 pero si esta orden fue obedecida, no hemos hallado los testimonios de lo que se actuase.

Es lo cierto, pues, que en los años 70 los Padres poseían el suelo de Sonora. Dicastillo supone incluso que impidieron desde el principio que los españoles fundasen estancias de ganados ni hiciesen siembras, "y que así como intentaba algún español hacer alguna casa en algún puesto conveniente para sembrar y criar ganado, luego iba el Padre más cercano y mandaba llevar una campana y se hacía una enramada y decía misa, y luego le mandaba a un indio hacer un jacarito que viviera allí $v$ sembrara algunas matas de maíces, y siempre han hecho esto". Tan curioso procedimiento se puede ver convertido en curiosa anécdota: el vecino del real de San Juan, Juan Martín Bernal, que había logrado posesión jurídica de un terreno en Teuricachi, tropezó con el P. Juan Antonio de Estrella, que hizo poner la consabida campana en el lugar donde aquél tenía su ganado, "y mandando el dicho Padre a los indios que tocasen siempre la campana se espan-

86 García de Salcedo a la audiencia. Parral, 30 junio I674. Ibid. 7-8.

87 Auto de 8 agosto I674. Ibid. 9-9v.

88 Auto del Consejo, 3 marzo I679. Patronato, 232, ramo $7 .^{\circ}$. R. C. 25 marzo 1679, a la audiencia de Guadalajara. Guadalajara, 23I, Z. 4. 3I3v.-3I5v. 
taba el ganado, que no paraba allí, y corría muy lejos, que se le alzó y perdió lo más del ganado".

Como resultado de esta actitud de los misioneros, eran pocos los labradores y criadores españoles de Sonora: según el P. Marras "es público y notorio que en las provincias hay muchas hnciendas de valor y estancias de ganado de españoles", pero no cita ninguna en apoyo de sus palabras. ${ }^{89}$ Es más explícito Dicastillo: "no hay en toda ella sino dos labradores, y estos son el capitán Matías Pereyra y el capitán José Romo, que siembran y cogen algún trigo, y el tuno de ellos no coge si no es para su gasto ordinario, sin que le sobre para vender"; y las demás labores eran ranchuelos que ninguno tenía para abastecerse. El capitán Matías Pereyra Lobo, el padre, ya difunto, vecino que había sido de Sinaloa y luego del real de San Juan, quiso poblar La Alberca, sitio con agua y a propósito para labor y ganados, y los Padres lo contradijeron, y él renunció por no tener pleitos. En otras ocasiones, los Padres hacían demostración de dominio sobre las tierras en sentido inverso: a Bernal que había obtenido merced real de ciertas tierras por el gobernador de Nueva Vizcaya, y pagado la media anata de dicho título, y que fue víctima de la campana del P. Estrella, quien además le amenazó que por la fuerza con los indios lo echaría de allí, y que le pondría pleito, etc., luego que hubo de llevarse lejos su ganado, al confín de la tierra de los indios gentiles, con gran peligro y costas y menoscabo, luego de esto el mismo P. Estrella le escribió ofreciéndole un sitio del pueblo de indios llamado Teras. Admitidos estos antecedentes, bien puede ser cierto lo que también el P. Marras declaraba contra Encinas y Dicastillo, expresado así : "Se dice aquí conúnmente que esta tierra no parece de Su Majestad", y "los que más bien sienten dicen que es lástima que siendo esta provincia de Sonora

89 Pedimento de Marras ante Hoyo. San Juan, 8 agosto 1673. Patronato, 232, ramo $10^{\circ}, 207 \mathrm{v} .-2 \mathrm{r} 8 \mathrm{v}$. Este es el más importante documento proporcionado por el P. Marras y sobre él asentamos cuanto se le atribuye en el texto. 
tan grande, rica y fértil no parezca que es del rey nutestro señor, que Dios guarde muchos años".

Gracias a ese dominio directo o indirecto del stuelo, los misioneros podían disfrutar de una abundantísima ganadería y de copiosas cosechas de granos. Los ganados eran propiedad de la Compañía; el P. Arteaga lo dice así en un texto recientemente transcrito, y alude a su introducción en las provincias, ya conocida por nosotros; también hemos sabido de su abundancia por las ponderaciones tempranas del obispo de Durango y por las más cré́bles alusiones del "Apologético Defensorio". Tampoco faltan otras a lo largo de la presente polémica: dice el P. Daniel Angelo que a los indios que labran las misiones, "por ser el comín del pueblo, les dan y matan mucho ganado los más domingos y fiestas principales del año, y también cuando les faltan los bastimentos, y en particular el dicho P. Daniel", como que "sólo en el partido de Matape se gastan cada día cinco reses en el tiempo que dura (el hambre), que suele ser de cuatro y cinco meses". En cuanto a los productos agrícolas "en esta tierra hav dos cosechas al año, por cuva causa hay también dos siembras, la tina es temporal y la otra es de riego, y cada Padre tiene dos y tres pueblos de su cargo, que a ésta llaman misión, y en cada pueblo de éstos le hacen al Padre una milna de trigo y otra de maíz, y éstas grandes con la siembra de algún frijol y algodón, con que vienen a ser, si son dos pueblos, cuatro milpas, y si son tres pueblos, seis milpas, y ya se extienden a más y en las meiores tierras que hay en los pueblos cada año". Ningún español podía conseguir bastimentos con esta. facilidad, pero gracias a ello podían los Padres socorrerse unos a otros en las malas cosechas y a los que empezaban a fundar misión. El P. Daniel Angelo prefería disminuir la importancia de las cosechas: "en el partido de Matape se coge muy poco maíz, por no haber tierras de verano, y el trigo que se coge es en tierras que si no fuera por la solicitud y cuidado de dicho Padre no se pudieran sembrar". Los indios sembraban un poco de maíz, como dos almudes, para sí -el trigo sólo para los Padres-, y no hacían 
sementeras de comminiclad. Y supone el ex alcalde mayor que si sembraran para ellos mismos habría mucha mayor abundancia en la provincia.

Lo definitivo para asegurar la potencia económica y social de los jesuitas en Sonora era que disponían de la mano de obra india, fuese como patronos, o fuese - y es más probable-- como administradores; porque les exigían el cultivo de su milpa de nua fanega, o porque los compelían a trabajar para los mismos pucblos, a encerrar las cosechas y a clesgranar las mazorcas y espigas, y a molerlas, y porque eran ellos quienes intervenían en la práctica las cosechas propiedad de los indios para su comercio.

Si la milpa era del Padre, éste debía, lógicamente, pagar el trabajo que requierese. El jestuita, según el fiscal de Guadalajara, lo que hacía eta dar de comer y vestir a los indios como si fuesen sus criados, pero es claro que la audiencia sabía que en las pro* vincias setentrionales el pago había de hacerse en géneros por escasez de numerario. Los Padres protestarán siempre que pagan. y aun con creces, las faenas de los indios, y hay que darles crédito, porque si en alguna o en muchas cosas pudieron equivocarse a juicio de un hombre del siglo XX, nadie podrá tacharles de haber ido a la frontera con a fán de lucro, con ánimo de explotar a los indios. llegando para ello a negar el justo salario del trälajador. "Los Padres --dice el misionero de Matape - pagan a los que grtardan los ganados en la ropa que han de menester para ellos y para su familia", y a los que cultivan las sementeras del partido se les da ganado en cantidad que bastaría para comprar doble cantidad de trigo de la que se coge. Para el trabajo del campo, cuenta Dicastillo, convoca el Padre a todos los indios. "La paga de estos trabajos es, mientras dura aquella limpia, o siembra, o cosecha, matarles una o dos reses y poner mas ollas grandes con maíz dentro y carne, y al día dos veces les dan de comer de esta carne y maíz, y esta es la paga que los dichos Padres misioneros hacen ordinariamente a los indios, y muchas veces se ha visto en una tava de estar andar trescientas personas, y tal vez cuatro- 
cientas; y que la paga que les hacen a otros indios que tienen ocupados todo el año, como son vaqueros que guardan el ganado, y recogedores de manadas de yeguas con burros, y arrieros y domadores de mulas, $y$ otros hortelanos, $y$ otros panaderos, y otros carniceros, y otros del servicio de la persona de los padres, y otros que hilan lanas, y los que tejen jergas, y otros mescaleros, que hacen vino de mescal, a todos estos les dan de comer maíz y carne, y en el discurso del año les suelen: dar cuatro varas de sayal o una vara de paño y alguna cosa para la mujer del indio, como es un, güipil o naguas de Ilotepeque, una de las cosas dichas a cada uno, y no otra; con esto, no hay más cuenta ni paga en todo el año".

Esta retribución podía ser alta o baja según el nivel general de salarios del país. Dicastillo intenta persuadir lo segundo alegando que los vecinos de la provincia se quejaban todos, salvo dos o tres, de estar pobres, y también los mineros, por razón de las pagas que habían de hacer cada año a sus operarios, y de las compras que tenían que hacer de bastimentos, "conque aquí se conoce que si los que tienen en esta tierras la labranza de ella pagaran a los indios no les sobraría nada, como no les sobra a dos o tres seculares que de poco tiempo a esta parte se han retirado al valle de Bacanuche, entre gentiles, a ser labradores, y dicen que lo quieren dejar, porque ven lo poco o nada que se interesa, por cuya causa, si los $\mathrm{Pa}$ dres misioneros pagaran a los indios, tampoco sembraran, pues de ello les quedara poca o ninguna utilidad". En Sonora no se labraba con bueyes, sino que se sembraba a mano en hoyos, y no se trillaba el trigo, sino que se desgranaban a mano las espigas, o las sacudian con palos, y para tales faenas reunían los Padres a todos los indios que necesitaban, y al decir del antiguo justicia - contradicho, como se ha visto, por el P. Marras- había cosechas de mil, dos mil y tres mil fanegas.

Dicastillo pone todos los colores para ofrecer la imagen de un misionero que sea empresario, hacendero o señor feudal de los dos o tres pueblos de su misión. En su retina se confunde la cosecha del Padre con la propia de los indios, el trabajo artesano de 
éstos, con el que parece les encarga el jesuita. Probablemente éste, en cuestión de cosechas, no hacia distingos: de todos modos, si los indios pasaban hamhres, él les daría suls reses y sus maíces; y si él quedase sin granos no tendría dificultad en adquirirlos de los indios. Pero puesto que éstos sembraban poco para sí, debía ser propio el maíz y el trigo con que comerciaba el Padre, guien también podría ocupar a los indios en hacer candelas del sebo de sus ganados, que rendían, y en hacer y curtir corambre, "para lo cual tiene tenería el P. Daniel Angelo Marras": "y también hasta el tiempo presente nolían las indias a mano en metates, no sólo el trigo del común de los Padres, sino todo to que vendían y segaban en esta provnicia”.

Los Padres alegan siempre que ellos se ven obligados a hacer trabajar a los indios - esto, ya es bastante, no lo niegan- porque son flojos. Cada misionero, establece terminantemente el P. Provincial, "está obligado a cuidar del bien espiritual de las almas a su cargo y juntamente a no descuidar de lo temporal de sus casas, antes sí debe cada uno cuidar tanto de la conservación y aun del atmento en to temporal cuanto es necesario en aquellas provincias, en ese y aqueste reino - esto es, en Nueva Vizcaya y en Nueva España--, que el abasto en lo temporal conserva a los indios en sus pueblos, y los tiene debajo de campana para enseñanza de la doctrina evangélica, como la falta de sustento y del vestido los ahuyenta y retira a los montes o a las poblaciones de los españoles, donde olvidan hasta el saber persignarse". 90 Otro texto dice más gráficamente que la religión, al indio, por la boca le ha entrado y por la boca se le ha de conservar. Y para cue el indio pueda comer en el pueblo y no se vea precisado a ir a buscar raíces, sabandijas y caza del monte es preciso que el Padre supla con su previsión la indolencia del indio. La verdad, según Dicastillo, es que los indios etudeves eran naturalmente trabajadores, y que los conquistadores hallaron sus valles llenos de milperias, y les costaba el maíz muy

90 Doc, cit., en nota 85 . 
barato, y que con un cuero de toro o de vaca rescataban en tiempo de cosechas maíz para todo el año. Podemos convenir nosotros con nuestro polemista en la laboriosidad de los eudeves, pero no en la baratura de sus frutos, porque salvada la posible exageración de la frase, siempre indicará ésta mejor el aprecio de los indios a un cuero, que no el valor intrínseco del grano: nadie dirá, cuando los indios cambiaban oro por espejos y cascabeles, que el oro estaba barato en Indias.

Otra cosa es cuando los Padres alegan que los indios son brutos o inútiles. Es cierto que un creciente pesimismo se va apoderando de los misioneros con el transcurso de los siglos, y esto es visible - lo ha apuntado con gran tino el P. Fintan Warren O. F. M.- en las crónicas o historias de los mismos jesuitas de Sonora. Pero en sí el indio era seguramente apto para cualquier tarea con poco que se le adiestrase. Los primeros misioneros estaban seguros de ello. E1 "Apologético Defensorio" hace una verdadera exaltación de la habilidad y aplicación del indio comparándole precisamente con la desidia de los españoles de la villa de Sinaloa. Luque, en su acusación, alude a una serie de actividades en las que los indios servían a los Padres. Dicastillo nos ha hablado ya de otras, y aún dirá más: "A los que saben la lengua de los indios, y les saben mandar, ellos saben obedecer y hacer cualquier cosa y otra, aunque sea de primor, y para que se vea su ingenio hasta donde llega, ellos, si los enseñan, en breve tiempo aprenden a leer y escribir, como se conocen hoy muchos que lo saben; también aprenden muy bien a cantores de punto de solfa, $y$ han en cada misión su capilla de indios cantores, con sus instrumentos -algunos indios han llegado a componer música, dice el "Defensorio". Ellos han aprendido a tocar en arpa y guitarra sin enseñárselo de propósito, y hay indios carpinteros y cerrajeros y zapateros y sastres; hay también hiladores de lana y tejedores de jerga, y coraceros, curtidores y zurradores, hacen muy lindas medias de algodón y las indias saben hilar con mucho primor y tejer manteles y servilletas extremadas, y tejen también paños y toallas muy 
finals, y si les dan sedas de colores tejen colchas de admirables labores y de mucha cuental para diferentes personajes por orden de los Padres misioneros, y tejen muy lindas mantas de algodón de que hacen tiendas de campaña parit caminar, que son de mucha estimación por la calidad del tejido, y las suelen vender los Padres a 80 y 100 pesos un pabellón de in asta, y las de a clos, a i 50 pesos".

Aqui hemos de dar cuenta de lo ocurrido, importante y significativo incidente, nacido de la misma polémica. Ello fue que el P. Daniel Angelo, molesto por las recriminaciones de Dicastillo sobre el trabajo que éste suponía daba a los indios, tomó la abr surda y a un tiempo reveladora decisión ; de hacer traer negros desde México, para trabajar las tierras de la misión! Así lo declacar el mismo misionero de Matape en uno de sus pedimentos, y Dicastillo cuenta haber sabido de fuente del mismo Padre que éste tenía enviada orden y plata a México para que le enviasen hasta sesenta esclavos. El ex-alcalde mayor apunta los inconvenientes graves de esta medicla: porque los negros malearán a los indios, $\mathrm{y}$ si se juntan y alzan molestarán los caninos, y aun podrán alborotar a los gentiles. A poco de llegar los primeros, ya se le habían huído algumos al misionero de Matape, y otro le hurtó ropals y plata de su casa mientras Marras andaba en el real de San Juan sosteniendo su controversia con Dicastillo. Perseguido ese ladrón mulato, llamado Pascual, se apuñaló -a aunque no llegó a darse muerte- antes de caer en manos de los que lo buscaban.

Pero lo que más dolía a los españoles que participaban de la opinión de Dicastillo, y que al mismo tiempo era la mayor victoria de los jestritas, era el dominio que éstos ejercían sobre los indios: estaban apoderados o hechos dueños de ellos, gracias a que sabían sus lenguas. "Sólo penden del Padre misionero y no hacen sino lo que él quiere y manda según los tienen impuestos por lo mucho que les temen y por hablarles en su lengua, que aquí no entienden los alcaldes mayores, ni para su inteligencia tienen ni han teniclo intérpretes, y apenas hay quien lo pueda ser, por ser muchas y va- 
rias las lenguas de los indios y pocos las entienden, si no es cada Padre en su misión". Así, en la práctica, sólo del Padre depende el indio. Cuando Dicastillo pasaba, siendo alcalde mayor, por $\mathrm{Ma}$ tape, camino del real de San Miguel o de otro pueblo, hallaba a las puertas de la ficticia casa de comunidad "algunos indios e indias que para muestra de obediencia a la justicia se ponían allí a un lado y otro, en hilera, para que a los indios e indias les fuera poniendo la mano sobre la cabeza, como es costumbre en esta tierra hacerlo así los superiores de los indios, sin que en otra cosa pudiera tener mano en dicho pueblo". Avisaba al Padre que iría a besarle la mano, y éste le daba de comer a él y a sus acompañantes, pero no le dejaba entrar en el gobierno de los pueblos. El teniente de gobernador y visitador de Sonora don Francisco Coto, que procuró dar la forma conveniente a los naturales de ella, salió a hacer su visita proveído de bastimentos y de todo lo necesario para no tener que pedir cosa alguna a los misioneros, pero no tuvo éxito: de nada sirvió, por ejemplo, que hiciese sacar un cepo de la cárcel que un Padre tenía en su casa; luego, éste - que todavía vivía cuando Dicastillo lo escribe- hizo fabricar tres.

Pasemos al punto del aislamiento del mundo misional de los misioneros. Contrariamente a Pérez de Ribas, que comprende de qué manera el trabajo en las minas, más productivo y mejor pagado siempre que el de la tierra, beneficia a los indios y les permite mejorar su nivel de vida, los jesuitas de mediados del XVII, por pretendidas razones morales, procuraban evitar que sus neófitos acudieran a trabajar a los reales y haciendas de sacar plata, diciendo que los españoles eran escandalosos en sus pecados, y que sacando a los indios de sus pueblos les impedían que sembrarsen y guardasen sus ganados; que en los reales vivían los indios amancebados, aprendían la lengua castellana - se hacían ladinos- y aprendían lo que no debían saber, no volvían a sus pueblos y se llevaban indias robadas; no oían misa y morían sin confesarse. Así se explica que el P. Marras contradijese el que don: Laureano Gascón de Prado fundase hacienda de sacar plata para explotar una 
rica mina que descubrió en el paraje de Banachare, cercá de Matape, y sobre esto tuvieron en la audiencia reñido pleito en que al fin tue vencido el Padre.

Los Padres ejercitaban frecuentemente sti absoluta autoridad subre los indios para no admitir los sellos de la justicia para enviar algunos a algím español no grato a los misioneros, dando cualquier excusa. A Dicastillo le había ocurrido algún caso siendo alcalde mayor, y también a Juan de Munguia cuando lo era. Tanbién solian impedir a los indios el comerciar directamente sus géneros con los españoles. Antes vendian los indios algún maíz o frijol y otras cosas a cambio de paño, sayal, naguas de Ilotepeque, giiipiles, y quesquemiles para sus mujeres y frezadas para abrigarse del frio, y cosas para limpiar y sembrar sus milpas, pero ahora los indios vivían lejos de los pueblos, no tenían mulas para acudir y nadie iba a venderles, porque los Padres tenían de todo. Dicastillo recuerda que un indio podía ganarse la vida con una barra, trabajando apartado, independiente, en un real de minas, arrancando algunos minerales, o bien yendo a pepenar, juntando algumas piedras en los terrenos y fundiendo sus metales, y entendiéndose directamente con el mercader, que le fiaba las ropas y los maíces a cambio del rescate.

En sus propios lugares, descle la conquista no habían tenido gobiemo ni policía los naturales. En sus pueblos no había siembras de comunidad, ni aranceles para el avio de los pasajeros. Los caminantes no hallaban indios que por precio alguno les diesen de comer, ni les vendiesen lo que necesitaran, ni les alquilasen una bestia sin permiso del misionero. Así lograba éste que nadie tuviese comercio ni comunicación con los indios, y lograba que los españoles respetasen su autoridad y lo necesitasen. Pero con esto también, vivían en la miseria los indios de misión : los gentiles - si es que el parangón puede admitirse - sembraban mucho maíz, lo guardaban en sus trojillas, y siempre podrían vender entre año, lo cual no ocurría con los indios cristianos de Sonora, cuya pobreza y desmudez era extremada, "y los que hemos entrado y habemos ca- 
minado por tierra de indios gentiles sabemos por- haberlo visto que andan vestidos ellos y sus mujeres, y que tienen sus casas, buenas a su modo, y que tienen y cuidan muchos carneros, y gallinas, y tienen sus caballos, y en particular los del contorno del real de Ostimuri y desde allí al Parral por nás de ciento tneinta leguas que se caminan por tierra de estos indios gentiles". Siempre es dolorosa esta comparación, sobre todo por lo que podía dificultar las conversiones, porque los gentiles no querían hacerse r.ristianos viendo lo mal que vivían los indios reducidos.

Para mejorar su condición debían los indios producir más, pero para aumentar su productividad era preciso que se les despertase el afán de lucro, lo cual no era posible mientras fuesen los misioneros quienes comerciasen los frutos a su arbitrio, administrasen las ganancias, los redujesen al trabajo exclusivo de la tierra y a vivir de su paternalista protección y ahogasen con su abrumadora autoridad toda iniciativa del indio - salvo cuando éste, que sin duda era capaz de ella, huía de la misión para ir a trabajar en las haciendas y reales. ¿Nos atreveremos a decir que el gobierno de los Padres -es seguro que éstos tenían el efectivo gobierno temporal de los pueblos, como lo dice o lo insinúa el fiscal Haro:pudo ser siempre y en el peor de los casos bienintencionado, pero no fue igualmente educativo? ¿Habremos de ver en el mismo. arraigo de los Padres en lo temporal el notorio fracaso que supone el hecho de que un siglo después de la llegada de los primeros a Sinaloa, medio siglo después de su entrada en Sonora, siguiesen siendo estas provincias de misión - hablamos sólo de I690, no de 1767 ?

Mírese como se quiera, hablando sólo de las fuerzas económico-sociales, he aquí bien delimitado el campo, el mundo agrícola-ganadero de Sonora, totalmente personalizado por los Padres, por violento que parezca el cuadro. Ellos son quienes gobiernan los pueblos, controlan su trabajo y su producción y -aquí es donda más se acusa su presencia- quienes tienen la exclusiva del comercio de granos, de los productos de la artesanía e industria 
indígena, y por suptresto, de ganados, Es inútil que el P’. Daniel Angelo afirme que "rescatador es espanoles entran a rescatar entie los indios cristianos" - -no favorece su catusa, según se ha visto, el antadir como lo hace "y gentiles". También dice que los misioneros dan a los indios semillas para que siembren y cojan para sustentarse y vender a los espanoles. "Solamente en el valle de Cumpas y Oposura se rescata cada año de los indios más de dos mil fanegas de maíz, sin los más valles de la provincia". Adinitida la cifra - ¿cuánto necesitaban los espátioles?-y los demás rescates; pero entonces, ¿mintieron todos los que en las repetidas informaciones, declaraciones previo juramento y pedimentos de los vecinos hechos a favor de los Padres declararon insistentemente que sin los auxilios de granos de éstos no se podía poblar ni vivir en Sonora? Dicastillo strpone maliciosamente que los jesuitas se habían aduenado de las tierras, de los indios y de su comercio, e impedian a los espanoles establecer haciendas de labor y de ganado, con objeto de ser ellos inicos dueños de todos los bastimentos de toda la provincia, con una clara mentalidad nonopolista, movidos por fines mercantiles o por ejercitar su poder: "Siendo notorio que tiene este Palde (Daniel Angelo) y los otros misioneros la llave de abrir y cerrar los manteninientos en esta provincia y de la hambre o abundancia de ella, porque no están ni vienen por otras manos". Por eso bastó a Marras retirar el suministro de bastimentos a los reales, a raíz de la provisión de la audiencia, para que todos clamasen en loor de los misioneros y en justificación de sus ventas. El ser los únicos dueños cle las vituallas permite a los Padres ponerles el precio "y tenerles a todos los españoles la llave del pan y de la carne, como hoy la tienen". Don Gregorio no vacila en asegurar que algunos hacian uso de esta llave contra los españoles que no les eran sumisos y gratos, o bien como recurso coercitivo para cobrar deudas de los mineros y recinos. Los misioneros, si no les gusta algún español, no lo reciben ni atienden cuando viaja, "y si acaso se le ha soltado alguna palabra en algúm tiempo en contra del gobierno y estilo de los Padres, aunque vaya 
desde Guazavas a Sinaloa, que hay doscientas leguas, siempre halla el mismo agasajo, porque se avisan unos a otros, y el pobre nunca camina sino por tierra de enemigos"; lo contrario ocurría si el viandante era afecto a la Compañía. Por eso nadie hablaba ni podía sacar la cara, al decir del corrosivo Dicastillo.

Los Padres comerciaban en todo, y tenían todo el comercio de Sonora; según Dicastillo, contra su instituto; según la voz de Marras, más autorizada en la materia, con autorización de sus superiores, siendo Colegio Matape. Las palabras del Provincial parecen darle la razón, al menos en su espíritu. Y nosotros estamos hablando aquí de economía y de justicia, no de la observancia de las reglas por parte de los misioneros. En el peor de los casos, veremos surgir en Sonora un poderoso y absorbente trust, pero nadie podrá hablar de corrupción personal ni colectiva, como tampoco se nos ocurre hablar de teocracia, palabra tan cara a los defensores de las libertades humanas.

Vendían, pues, los Padres a los españoles mineros y mercaderes y a todo el común harina, maíz, frijol, carne, y todos los demás géneros procedidos del mucho ganado mayor y menor que les cuidaban los indios, y al haberse ido aumentando la población y el gasto de los reales, habían aumentado ellos proporcionalmente sus siembras y sus moliendas, y para esto último habían construído recientemente algunos misioneros tahonas, mientras que en otros pueblos todavía se trabajaba en los metates a mano. Ni que decir tiene que también vendían las mantas, colchas y tiendas de campaña. $Y$, punto principal en la materia, los Padres tenían su propia tienda para comerciar con los indios. Sobre la fuerza que les daba el monopolio de los artículos alimenticios, hay que calibrar el daño que causaba su comercio en otros géneros a los mercaderes de los reales, que no podían sufrir su competencia: una entidad económica de este tipo es, por naturaleza, excluyente. Malo es que su ingerencia en el gobierno de los indios apartase a éstos del beneficio que hubiesen obtenido en el trabajo de las minas, única ocupación, aunque arriesgada, rentable. ¿Pero, cómo valorar la suc- 
ción de riquè que su ventosa comercial ejerció constantemente sobre la provincia y el raquitismo a que concienó a las empresas ganaderas, agrícolas, mercantiles y mineras de los españoles?

Eil imico criador de sanado en mediana cantidad había sido Matías Pereira, y el P. Marras se optuso a que hiciese postura para el ahasto de carnes del real de San Miguel, por ser él el vendedor, y, como era de esperar, tuvo a los vecinos de su parte. Le servían de intermediarios al Padre el sargento Cristóbal de Ibarra Guinea y luego, en la época en que escribe don Gregorio, dan Pedro tirancisco de Sartillón, ay udándole en el cobro Pedro de Camorlingo, mercader. Entonces Pereira empezó a vender la mayor parte de su ganado al por mayor para tierra afuera, y habían quedado los Padres casi únicos dueños del género, y cualquier vecino que hacía postura de alrasto de carne en algún real tenía que comprar el gamado a los Pádres.

Tenian los jesuitas de Sonora todo el comercio de granos, que les producía muchos, grandes y gruesos tratos y grangerías, aunque Marras dice que sólo enviaba algunos bastimentos a Sartillón para alivio de los necesitados, y ctue no se dedicaba a aviar haciendas, habiendo tan sólo socorrido con lo que pudo la hacienda y casa de los Rochas, "y si acaso a otros vecinos del dicho real (de San Miguel) ha dado algún bastimento no ha siclo por razón de avio"; pues no debía ser cosa tan de ocasión, cuando más adelante añade que lo más del trigo que él cogía en Matape servía para "remedio" de los españoles, sobre todo los de San Miguel, "a cuyos vecinos más necesitados se ha socorrido con ellos, como con otros muchos (granos) que el Padre hacía conducir de otras partes remotas y hasta de la misma gentilidad dándolos al mismo precio que los compraba sin interés alguno, y cuando los españoles que al dicho real conducían algunos bastimentos los vendían a siete, ocho y diez pesos fanega, el dicho Padre Daniel los daba a tres pesos, que era el costo, en lo cual, adenás de no haberse el dicho Padre apartado del cumplimiento de las obligaciones de su estado y profesión, ha hecho gran servicio a ambas Majestades". 
Como era de esperar, Dicastillo ve las mismas cosas con un color diferente: siendo tan fértil el país y tantos los indios cultivadores, extraña que "nunca baja el precio de la harina de diez pesos carga, y en particular en el real de San Miguel, y por saber (se) fuera de esta provincia que los Padres de la Compañía son los que venden en ella todos los mantenimientos forzosos, no acuden a venderlos de otras partes, ni los envían, como vinieran y entraran a la fama y voz de la plata que hay y saca en ella; y tal vez de Sinaloa suele venir algún maíz al real de San Miguel, pero en muy poca cantidad y raras veces, y también lo suelen traer y comprar de los indios gentiles, que con serlo, lo tienen para vender todo el año, y los que son cristianos en esta provincia no lo tienen por las causas dichas".

Tres años atrás, cuando Dicastillo no había aún llegado a la provincia - escribe el I9 de octubre de I673- hubo año estéril y también lo había sido el anterior. El maíz llegó a valer en el real de San Juan a diez pesos fanega, y en el real de San Miguel a marco de plata. E1 P. Marras no se atuvo a los precios y vendió su maíz a tres pesos en su misión y a cuatro en el real, y por esto le estaban muy obligados en San Miguel. Don Gregorio recoge la maledicencia del arroyo de que el Padre obró así por poder publicar esta buena obra, como lo hacía, y por ganar adeptos; y añade con más seguridad que lo hizo así porque tenía los trojes llenos y porque en aquel tiempo dio salida a una gran cantidad de ropa que tenía en su tienda de Matape, y la envió a todas las misiones para que con ella se rescataran granos: y esto dio lugar a que muchos pobres que durante la escasez se dirigieron al valle de Sonora, Cumpas y Oposura, no pudieran adquirir maíz, porque los Padres habían acaparado ya todo el de los indios.

A continuación el insaciable Dicastillo arremete contra dos fábulas con que los Padres y sus afectos justifican y ensalzan las ventas de los primeros: son la del socorro de los pobres y la del fomento de la provincia. La primera, tal como se pinta en boca de don Gregorio, equivale a la práctica del "dumping". E1 P. Marras 
vende el llamado "maíz cle los pobres" en el real de San Tuan a tres pesos de plata al contado y a los ricos se lo vende por muty poco más. "Industria grande - hasta donde llega la mala fe de mercader de Ijicastillo?--, por vender él sólo y cogerse toda la plata, porque a este precio no hay ningún hombre que tenga recua que lo puecta ir a rescatar a los pueblos de los indios gentiles, que lo pueden dar y lo tienen, por cuanto pagan mozos y tienen el gasto de lo que montan los fletes". A los Padres, como nada les cuesta sembrarlo ni acarrearlo, o así imagina su contradictor, "aunque lo dieran a peso fanega, ganaran y no perdieran".

De este modo habían arruinado el tráfico de nutuchos pobres vecinos que traían granos de los gentiles. Los mercaderes entregaban antes ropas a los rescatadores por valor de quinientos a mil pesos, y estos al cabo del año las habían convertido en plata y maíz. Las platas entraban en el connercio y los mercaderes avisaban con el maíz algunas haciendas. Ahora los rescatadores sólo recogen plata a cambio de los bastimentos de carne, maíz y candelas que envían los Padres, y el P. Marras envía así cada año a México más plata que todos los mercaderes juntos, y éstos no venden ya casi nada de ropa a los indios, porque los Padres la traen de México para los indios y para sus criados y pajes, "porque el porte de los Padres es más que de misioneros".

En el otro caso, Dicastillo revela igualmente lo que hay tras una palabra: Jos Padres llaman "fomento" a vender los bastimentos por plata contada, limpia, fina y de la nejor, $y$ nunca fían. $Y$ la prueba es que de tantos bastimentos qute en tantos años han vendido no le deben hoy nada al P. Daniel, y a todos los demás Padres juntos no les deben dos mil pesos, que sólo al P. Juan de Uter le cleben alguna cantidlad, mientras que los mercaderes qute entran en la provincia tienen que fiar a los mineros, y después les tienen deudas que hoy pasan de doscientos mil pesos, "y no en ditas seguras ni buenas, por la cortedad y pobreza a que han venido los dichos vecinos y mineros". Marras había aviado las minas de Santa Bárbara y Banachare, la hacienda de Santiago de 
Tuapa y las de los Rochas y Luis de la Campa, que eran las dos más gruesas del real de San Miguel. En andando buenas las minas, acude el misionero de Matape de buena gana con la venta de bastimentos - maíz, manteca, candelas, carne de ganados en pie-"y que en conociendo que decrecen y le están debiendo alguna plata, se retira de aviarlas". Así lo hizo con los Rochas, que le debían novecientos pesos cuando les empezó a disminuir el rendimiento de la mina de las Animas, hasta que Camorlingo, a instancias de Sartillón, cuñado de los Rochas, saldó la detıda en sı nombre. Lo mismo había experimentado Juan de Sierra.

Parece lógico, después de todo lo dicho, que los Padres obtuvieran en su comercio crecidos beneficios, y esto además era visible "porque visto está que con trescientos quince pesos que S. M. da a cada misionero no podían beber chocolate, ni comprar especies, ni lienzo y ropa para vestirse, ni lo demás necesario". Son frecuentes las alusiones a la plata que los jesuitas enviaban a México. ¿Cómo se explicaría si no que el P. Daniel Angelo pudiera ordenar como confiesa la compra de esclavos para su misión? Pero el Provincial lo entendía de otro modo: "Es también notorio por la bondad del Señor que lo que los Padres misioneros o por industria y trabajo suyo, o de limosnas que les da S. M. el rey nuestro señor, la mayor parte gastan en adorno de sus iglesias en vestir y sustentar a los indios de sus partidos, no ya unos $u$ otros, sino familias $y$ pueblos enteros, y la menor $y$ muy pequeña parte gastan en sus menesteres, lo cual se reconoce con evidencia de las mismas memorias que acá nos envían, pidiendo en la mayor cantidad ornamentos, casullas, albas, plata labrada y todo el demás ornato de iglesias con todos géneros de vestuarios y menesteres para los indios que allí o se les da como a hijos liberalmente, o se les recompensa el servicio que hacen a las iglesias y casas de sus ministros". ¿Es posible presentar en menos palabras todo, absolutamente todo cuanto dice Dicastillo, pero bajo una luz ingenua y diametralmente opuesta? Pero el antiguo alcalde mayor nos puede decir alguna cifra sobre esas "memorias" 
de los Padres: en el mismo I673, envió Marras a México quince cargas de plata con su mayordonno de recta Ignacio González, recino de San Miguel. En I673 envió poco menos con st1 confidente Melchor de la Peña, y en i6 r i se llevó muchas cargas Pedro de Uríaz, también vecino de San Miguel, y lo mismo en años anteriores, y a todo ello hay que añadir la que mandaban los restantes misioneros. Serád posible algún dia contabilizar el río de plata que por las manos de éstos afluía a la capital del virreinato, para retornar converticlo en objetos clel culto y en nuevos géneros para el comercio con los neófitos?

Hasta aquí la triste, dramática pintura que nos hace Dicastillo, confirmada en muchas de sus partes por otras noticias suministradas por sus mismos antagonistas. Escaso campo de acción y reducidas posibilidades de desarrollo quedaba al grupo minero de Sonora. ¿Cómo podría sobrevivir y fortalecerse?

\section{Ia comisión de Juan Franco Maldonado}

Para crecimiento de su exasperación, conoció Dicastillo la segunda real provisión expedicla por la audiencia y la persona a quien se le habían cometido las diligencias para su promulgación: "es necesario y aun forzoso informar a $\mathrm{V}$. A. de la verdad, y es que el sujeto, para la práctica de materia y negocio tan importante no es en cosa alguna a propósito, antes lo es para que todo se empeore y se quede en el mismo estado que ha tenido hastal aquí, porque el dicho Juan Franco Maldonado, aunque es buena persona y muy devoto y que reza mucho, demás de ser muy viejo, es $u 11$ hombre muy simple y sencillo y que no sale un punto de la roluntad y gusto de los Padres de la Compañía de Jesús de esta provincia y está en todo sujeto a lo que le ha mandado y manda el P. Daniel Angelo Marras, el cual de mucho tiempo a esta parte le tiene hospedado en la casa de su misión de Matape y ahora tres años le vendía dentro de ella en una tienda de todos los géneros de mercadurías que allí se iban a comprar de distintas partes de 
esta provincia, y hoy en día le está vendiendo en dicha misión el dicho Juan Franco Maldonado al P. Daniel Angelo los géneros de bastimentos que a todos se venden en dicha misión, y el susodicho tiene las llaves de todo lo que hay en ella, que para esto lo tiene el dicho Pad1'e, y también le vende el mismo Juan Franco los que ha de menester el mismo para el avío de una hacienda de minas que tiene cercana a la dicha misión de Matape y se llama la dicha hacienda Santiago de Trapa, la cual fue de don Lat1reano Gascón de Prado, ya difunto".

Este había sido el comisionado, cuya designación se debió sin duda a las indicaciones del P. Gutiérrez, para poner' en vigor la real provisión de 20 de julio de 1673 . E1 P. Marras fue, claro está, la persona que la presentó, pidiendo stı cumplimiento, el $3 \mathrm{I}$ de agosto siguiente, en el ptreblo de Matape: "vista por mí, Juan Franco Maldonado, vecino y minero del real y minas de Santiago de Topa, la tomé en mis manos, besé y puse sobre mi cabeza y la obedezco y estoy presto a cumplir y ejecutar". or

E1 7 de setiembre, en el real de San Juan, requería Franco al alcalde mayor Hoyo, para que diese su obedecimiento a la real provisión y exhibiese del archivo del lugar la de 24 de diciembre anterior con los documentos anejos, a todo lo cual accedió don Domingo. E1 8, día de la Natividad de Nuestra Señora, se pregonó después de misa la nueva disposición por voz de Ignacio, mulato esclavo de los Sosas, en presencia de Hoyo, y luego de leída requirió Franco a todos los presentes fuesen testigos de esta publicación. E1 2 I de setiembre tenía lugar la misma en el real de San Miguel, adonde se había trasladado Franco. El 4 de noviembre se hallaba ya el comisionado en la villa de Sinaloa, notificando la real provisión a Barcelón, quien por ausencia de Calderón, que estaba en Parral, puso el obedecimiento y exhibió la anterior provisión, pero no más porque el alcalde mayor no le había dejado el archivo, "el cual vide yo y no hallé en él auto que tocase a

9I Patronato, 232, ramo $33^{\circ}$, IIV.-I 2 . 
visita de las que hizo en el río de la villa, habiendo declaraclo dicho teniente que hizo algunos autos de que fue acompañado". Al siguiente día 5 putblicó Franco la provisión en la villa, y luego, como había hecho en los pueblos de los ríos Yaqui, Mayo y Carapoa, hizo juntar a los alguaciles, alcaldes y topiles, con muchos maceguales que vinieron de los pueblos del río de Sinaloa, y por intérprete les dio a entender el contenido re la diltima disposición y el respeto rue debían a sus Padres. 92

Narrando el mismo Juan Franco el modo en que llevó a cabo su comisión dice 93 que después de publicada en el real cle San Miguel la provisión - - tan oportuna, porque las persuasiones o tatoles de unos pocos hahían puesto a las provincias muy inquietas, y en peligro de perderse el crédito de la Compañía-, le pidieron los Padres que pasase a los pueblos del Yaqui que estaban particularmente alborotados. "Y fue el caso que don Gaspar de Valdés, cura y vicario de los reales de San Juran y San Miguel, que hay cincuenta legruas de un real a otro, y Juan de Encinas, protector de los naturales de la provincia de Sonora. dieron vara alta a un indio yaqui y lo despacharon a dicho río de Yaqui, a que de su parte dijese a los indios que en cosa ninguna sirviesen a los Padres menos que pagándoles su trabajo, y que se aninasen, que dentro de breve tiempo vendrían clérigos que los administrasen, de que resultó que los indios empezaron a desvergonzarse y matar ganados de los Padres", con la natural aflicción de éstos. "Futi a dicho río, dije a los indios lo que V. A. mandaba, diles a entender la obligación que tenían de venerar a sus Padres ministros, con que quedaron tan otros que de vtrelta tan breve nos admiramos, quedando nuly contentos y desengañados y los Padres doctrineros muy gustosos; lice lo mismo en el río de Mayo y del Fuerte por haber acudido algunos tatoles malos que se habían dado en el río de la villa de San Felipe y Santiago

92 Ibid, I2-I $8 \mathrm{v}$.

93 Juan Franco Maldonado a la audiencia, Sinaloa, Io-14 noviembre I673. Ibid. 75 v. -79 . 
de Sinaloa, a la cual villa pasé luego y hallé algunos partidos que necesitaban de mi venida, porque don Miguel Calderón, alcalde mayor de esta villa, con el mal afecto que es público tiene a los religiosos ( $y$ no me espanto por sus obligaciones) de la Compaña de Jesús había sembrado entre los indios tal cizaña que ha sido muy menester todo to que V. A. manda en esta su sobrecarta que hice publicar en presencia de todos los españoles de dicha villa y muchos gobernadores y topiles y maceguales de diferentes partidos que hice juntar a su publicación, después que en común di los tatoles a los indios, y pregunté si alguno de los presentes u otros de sus pueblos vivían como esclavos o no tenían libertast para acudir a sus menesteres, mandé que me lo dijeran para poner en libertad al que así se hallase oprimido; respondieron que ni ellos ni los de sus pueblos carecían de libertad, que todos la tenían y vivían muy contentos. Aquí se me hizo saber cómo los indios de Guazave y Tamazula habían presentado unos papeles contra el P. Domingo de Treto que es el ministro que administra dichos pueblos, y que dichos papeles los habían entregado a don Miguel Calderón; pidióseme examinase a dichos indios. Dijéronme también que acerca de esta materia se había hecho cierta información ante el alcalde ordinario de esta villa, pero que no obstante, para mayor crédito de la verdad, examinase a los dichos indios; hícelo y cada uno en particular y todos me dijeron que no todos los indios concurrieron a dichos papeles, porque del pueblo de Tamazula fue solo uno sentido de que el Padre hubiese dado un leve castigo a una india parienta del autor; los del pueblo de Guazave aún fueron más, pero todos dicen que don Miguel Calderón, su alcalde mayor, los indujo y persuadió a que escribiesen dichos papeles, diciéndoles no temiesen, que él les ayudaría en todo, con que ellos de temor dicen que los escribieron y que ahora y siempre han vivido gustosos con su ministro (y no lo dudo, porque es amabilísimo), que no los ha vejado con trabajos algunos, que los que han tenido han sido hacer en tiempo del Padre dos iglesias y sembrado maíz para este efecto y para sustento de su Padre ministro". 
Sólo al principio usó éste de algín rigor, necesario por ser gente resabiada, pero no quieren otro Padre, y él les exhortó a terminar las iglesias y la casa del ministro, que Calderón les había dicho que no la teminaran si no les pagaba su trabajo el Pactre. "Ha11" que fuera del mal afecto que dicho alcalcle mayor tiene a los religiosos, se ha esmerado con el P. Domingo de Treto y es público que ha dicho 10 ha de dejar piedra por mover hasta echar de esta provincia a dicho Padre. Parecióme dar cuenta a V. A. cómo don Miguel Calderón y Ojeda prosigue en su oficio de alcalde mayor y Francisco Lucue en el suyo de protector, y cue parece no se trata de poner otro alcalde mayor, y por lo que he visto y reconocido digo a $V$. A. que menos que saliendo de estas tierras estos dos y de Sonora Juan de Encinas, protector, que no ha de haber paz, porque ha tiempo me consta sus inquietudes y naturales malos, no será posible que esto tome la forma y corriente que V. A. desea y estas provincias necesitan, porque estando estos hombres en ellas las han de revolver cada dia porque sus naturales inquietos así lo dan a entender, y más ahora, picados de que se hayan descubierto stus marañas".

Por su parte, al menos Calderón dio nuna versión distinta de lo ocurrido en la villa. 94 Estando él ausente llegó Franco y publicó la real provisión a favor de los indios, de que quedaron éstos nuty gustosos, y después el mismo comisionado llamó a los indios presentes y les dijo por tatole "que le sembrasen al P. misionero todo lo que su Reverenda Paternidad quisiese, y que le deben servir como de antes, y aún con más fuerza hoy, siendo el intérprete de dicho Juan Franco los mismos Padres que estaban presentes". Cuando él volvió fue a ver a Juan Franco y tuvo con él algunos encuentros sobre la materia de servir los indios sin paga, y le pidió un tanto de la provisión para el archivo de la villa, a lo que aquél se negó, y aun a mostrársela. En cambio, acudieron a Calderón los naturales y se le quejaron de que el rey los da por libres

94 Calderón a Haro. Sinaloa, 7 diciembre 1673 . Patronato, 232, ramo I. I 49V,-I5I. 
y los Padres les dicen que siguen como antes, y 10 mismo el capitán. Nada podia hacer Calderón, ignorando incluso el texto de la última real provisión, porque como asienta el propio comisionado, "no le di a dicho alcalde mayor tanto de la real provisión por hallarle y reconocer que no les es nada afecto a los Padres doctrineros como en dicha real provisión se menciona, la cual dicho traslado lo dejo en poder del R. P. vicerrector Pedro de Amaya de la Compañía de Jestís hasta que V. A. me mande otra cosa". 95

¿Qué había de pensar la audiencia a la vista de la interpretación que se había dado a su orden? ¿Quué decir habiendo hallado en Calderón y Dicastillo dos adversarios del régimen misional y en Franco un adicto de los Padres? En enero de I674 llegaron los autos del comisionado a Guadalajara, y sin que mediase nuevo parecer del fiscal se limitó la audiencia a disponer por auto de I4 de febrero 96 se despachase nueva provisión para que el gobernador de Nueva Vizcaya y sus alcaldes mayores cumpliesen la de 20 de julio de 1673 , entregando aquél a estos copia autorizada de dicha disposición que quede en los archivos de las alcaldías, para que la hagan cumplir pena de mil pesos aplicados por mitad a la real cámara y gastos de justicia”. El sentir del Tribunal aparece más diáfano viendo cómo ese mismo día ordena acuda García de Salcedo a Sinaloa y Sonora a repartir las tierras, aunque ya sabemos cómo quedó abortada esta vía para poner remedio a la situación de las provincias.

\section{Ultimas GESTIONES DE LA COMPAÑía}

\section{y DECISIÓN FINAL DEL CONSEJO}

Era de esperar que los jesuitas recurriesen a todas las autoridades posibles para justificar y acreditar el buen comportamiento

95 Auto de Juan Franco Maldonado. Sinaloa, I4 noviembre r673. Patronato. 232, ramo $3 .^{\circ}$, J9-19v.

96 Ibid, 79-79v. 
de sus miembros en las discuticlas misiones de Sinaloa y Sonora, porque dotada de tin notable espíritu de cuerpo, consideraban que este astunto afectaba al buen nombre de toda la Compañía. A la carta en que el gobernaclor García de Salcedo le había connunicado su deseo de que se retirase al P. Marras de la misión de Matape y la comisión que tenía de ir a repartir las tierras de aquellas provincias, habia contestado el Provincial P. Manuel de Arteaga que ya tenía encargado al visitador de las misiones la averiguación de los excesos que el gobernador refería, y que de salir ciertos sacaría al P. Marras y a cualquier otro que hiciese falta. Pero que entretanto guardase Salcedo el crédito de la Compañía, para que ésta no quedase desattorizada con riesgo de alboroto de los indios, "si llega a sus oídos la poca estina que en $\mathrm{V}$. S. han engendrado los informes que se han hecho contra los PP. ministros y maestros suyos". 97

Podemos conjeturar que el visitador hizo efectivamente $u n$ informe favorable acerca clel P. Marras, y que entonces los jesuitas de México se decidieron a dar un nuevo paso, como fue presentarse Antonio González, en nombre de la Compañía, ante el virrey el 20 de octubre de 1674 , para pedir se le recibiese información con cierto número de testigos que se hallaban en la capital sobre las misiones de Sinaloa y Sonora y las demás y la forma con que las administraban los religiosos y los agravios que les habia hecho el mestizo Francisco de Luque, nombrado justicia por el gobernador de Nueva Vizcaya. ${ }^{8} \mathrm{El}$ interrogatorio propuesto para la información 99 muestra una especialísima manera de abordar la cuestión, pues de los cuatro puntos fundamentales -quitados los dos de formulario - el segundo intenta acreditar el buen trato y sustento dado a los indios para que no se les vayan a los montes; y el quinto, que los Padres no han hecho agravio a los indios, "ni tienen ningún género de trato ni granjería de nin-

97 Doc, eit. en nota 85.

os Patronato, 232, ramo $4 .^{\circ}$, I-1V.

99 Ibicl, 2-3v, 
gún género"; mientras que el tercero pregunta "si saben que por haber declarado por excomulgado el rector de la villa de Sinaloa con orden del ordinario de Guadalajara al dicho Francisco de Luque por un amancebaniento de más de quince años, habiéndole nombrado por justicia el dicho gobernador, empezó a alborotar los indios sacando en su nombre una real provisión de la Real Audiencia de Guadalajara, que después se recogió, y publicándola con alborotos y escándalos, y por entender su lengua mudó sus cláusulas dándoles a entender que se dirigía a que los indios de ninguna manera obedeciesen ni asistiesen a los religiosos ni al servicio de sus iglesias" - ¿qué se puede decir de las inexactitudes que manifiestamente encierran estas frases? Y el cuarto punto supone que, por las causas indicadas en el anterior, los indios faltan -adviértase la fecha de este documento- cada día más al respeto de los $\mathrm{Pa}$ dres y a las iglesias", y que de esto se puede ocasionar algún alboroto entre ellos y levantarse los pueblos y volverse a su gentiliclad".

A esta solicitud dictaminó el fiscal de México licenciado don Martín Solís de Miranda que, "sin que sea visto perjudicar la jurisdicción ni el fuero de ella a quien le perteneciere”, podía el virrey autorizar se recibiese la información, ${ }^{100}$ y así se llevó a cabo ror ante el escribano Anclrés de Palomares Castro, entre los días 23 de octubre al I3 de noviembre de 1674 , y en este plaze declararon nueve personas: vecinos de Sinaloa y Sonora, arrieros y mercaderes viandantes de aquellas provincias, un soldado del presidio, dos antiguos cabos caudillos de éste -don Juan Francisco Goyeneche y don Alonso Ramírez de Prado, a la sazón racionero de la catedral de México - y un ex-gobernador de aquellas provincias: el general don Gaspar de Quesada Hurtado de Mendoza. Las declaraciones, vagas y retóricas, sólo ofrecen detalles al aludir a la persona e intriga de Luque, y en alguna ocasión confirman la nada posible suposición de que éste se halló a la publicación de la

Ioo Dictamen del fiscal, M'éxico, 22 de octubre r674. Ibid, 2.

IoI Ibid. $3 \mathrm{v},-25 \mathrm{v}$. 
real provisión y tergiversó maliciosannente la traducción de sus conceptos a los inclios.

Con este poco apreciable funclamento volvio a parecer Antonio González ante el virrey pidiéndole determinase se mantuviesen las misiones sin novedad. ${ }^{10 z}$ fil fiscal dio tin dictanen de este tenor: "como quiera que aś lo que mira al reo que resulta culpado - Lucure- como por lo que toca al real patronato en defensa de los misioneros pertenece a otra jurisdicción y corre por cuenta del gobernador y capitán general de la Nueva Vizcaya y real andiencia de Guadalajara", se debía disponer que la parte acudiese con la información a donde le conviniese. ${ }^{03}$ El 5 de diciembre de 1674 lo dispuso así el virrey. 104

A principios del siguiente año, el P. Antonio Suárez, misionero de Sahuaripa, promneve ante el capitán Mannel de Ojeda, alcalde mayor y capitán a guerra del real de San Ildefonso de Ostimuri y su distrito, se le reciba información de haber sido falso d informe que hombres poco ajustados hicieron al gobernador de Nueva Vizcaya y a su Superior mayor y Provincial. 105 Dice el P. Suárez actuar con poder, orden y mandato de sus superiores, y particularmente del más inmediato, P. Rector Alonso de Vitoria, de la mision de San Francisco de Borja. También su interrogatorio consta de cuatro puntos a saber: I) si los Padres quitan sus tierras a los naturales; 2) si los castigan por doctrina o misa o por tenerlos trabajando para sus granjerias; 3) si los hacen trabajar mucho sin pagarles; 4) si las siembras son excesivas, con mayordomos pagados y grandes recuas para remitir los bastimentos. Del 23 al 29 de enero de 1675 pudo presentar Suárez nueve testigos en abono de las tesis negativas de aquellos cuatro puntos. го́

A continnación, del 30 de enero al i de febrero, el P. Vitoria

I03 Ibid. $25^{\vee},-26$.

I03 Dictanen clel fiscal, 26 noviembre I674. Ibid, 26v.-27.

I04 Ibid. 27.

I 05 Real de San Ildefonso de Ostimuri, 23 enero 1675. Ibid. 28v.-29v,

roú Ibicl. 30-54. 
hacía recibir declaraciones de testigos españoles e indios sobre los mismos extremos, ell el real de San Nicolás, ante Miguel de Villanteva, teniente del alcalde mayor en dicho real. Así depusieron siete vecinos y mercaderes y seis indios. ${ }^{107}$ Los veintidós declarantes difieren en algunas cuestiones, pero su testimonio es valioso por la luz que arroja sobre ciertos detalles que hasta ahora habian quedado sin tocar en la polémica antecedente. El bachiller don Juan Laso Cordero, aura de San Ildefonso, dice que los $\mathrm{Pa}$ dres no tienen tierras ni para huerta, mientras que el mercader Francisco Flores se limita a declarar que siempre ha visto pertenecer a la iglesia las mismas tierras; el capitán Domingo de Paz asienta que los Padres trabajan por sí mismos para mantenerse, y el bachiller Cristóbal de Mendoza, en San Nicolás, dispone que el P. Francisco Liserino encierra para los indios y para el año siguiente, para tener qué darles y que no se le vayan al monte, más de mil fanegas de bledo y mezquite, además del maíz y trigo - suponemos que todo ello del Padre; y que sólo vendía algunos bastimientos a trueque de cera $\mathrm{u}$ otras cosas para la iglesia.

El capitán Pedro de la Vega se adelanta a decir que los Padres compran a los indios algunas tierras por más de su valor, y Francisco de León, que la iglesia tiene tierras señaladas. En fin, si los indios Pedro Cheno y Diego Bacumara declaran que a ellos nadie les ha quitado sus parcelas, otro indio - Gaspar de Figueroaatestigua que los Padres "aunque tengan muchas tierras, no se las quitan los Padres doctrineros, antes ellos (los indios), no teniendo herederos, en artículo de muerte se las dan a la iglesia de su voluntad, y que si algunas tierras los demás indios del pueblo tienen de sobra, se las pide el Padre y se las pagan muy bien, y que todos quedan contentos"; y un cuarto natural, Luis Conibuamea, dice que efectivamente sobran muchas tierras por haber muerto mucha gente por las pestes.

107 Ibid. 54v.-87v. 
En cuanto al trabajo de los indios, el misionero de Sahuaripa tenía necesiclad de bastinentos, por haber dejado a la voluntad de sus neófitos el que le trabajasen algo para su sostenimiento, y éstos lo descuidaron; pero el Padre quedó muy gozoso porque los inclios se habían cuidado de stis propios cultivos. Los Padres pagaban a los naturales con exceso, de modo que éstos venían a estar menos necesitados que los españules pobres. Los inclios, por otra parte, podian comerciar libremente sus granos con los mercaderes y tratantes de los reales. El Br. Mendoza indica que los indios trabajan muy a gusto para los Padres porque éstos les dan muy bien de comer; que si todo el año les dieran trabajo, todo el año fuese Pascua para los indios. Caso contrario al del misionero de Sahuaripa ofrece Francisco de León al decir que, si el Padre no tiene maíz, los indios pasan hambre, "que atenidos a lo que el Padre siembra están todos", y Prudencio Tello cuenta liaber visto al P. Francisco de Sepúlveda sustentarse con hierbas por haber dado sus bastimentos a los maturales de Chicorato y Mocorito.

Sólo un testigo recuerda que los Padres tienen como mayordomos asalariados "algtunos pobres de solemniclad, a los cuales les ayudan en lo que sus fuerzas alcanzan prestándoles las mulas para que con ellas socorran sus mecesidades". La recua de cacla misión oscilaba entre seis y doce mulas - sólo los Colegios de Sinaloa y Matape tenían recuas grandes - y los Padres las ntilizaban para llevar sal y granos a su particlo, para transportar géneros y ropas que repartir a sus indios, o bien para conducir imággenes y otros objetos para el culto de las iglesias.

Es posible que alguna parte de los datos favorables a los misioneros que acabamos de recoger se daba a la toma de conciencia de determinados problemas que quizá se produjera en algunas mentes a raíz de la polémica suscitada por Luque, Calclerón y Dicastillo. El Br. Laso Cordero redondea la anterior información con un certificado en que acredita la buena armonía y mutua ayuda en que se mantiene con todos los misioneros de las inmediaciones del 
real de San Ildefonso, y el espíritu caritativo de éstos para con otro clérigo secular. ${ }^{108}$

No debió quedar muy satisfecha la Compañía de los instrumentos que tenía en su mano -o bien se esforzaba mientras tocando otros resortes - cuando hasta octubre de 1676 no presentó el P. Diego Díaz ante la audiencia de Guadalajara los expedientes promovidos en 'México, Ostimuri y San Nicolás, junto con la "retractación" de Luque, solicitando que, enterada de todo la audiencia, amparase y defendiese a los Padres y pusiese estos autos con los de los contrarios para que en todo tiempo pareciese la verdad. ${ }^{109}$

Aquí concluye, prácticamente, el debate sobre tierras, indios y comercio de Sinaloa y Sonora, a lo menos tal como nos es conocido. Cuando el P. Díaz presentó su pedimento se había recibido en la audiencia una real cédula de 2 de abril de 1676 en que se ordenaba remitir al Consejo de Indias los papeles, autos y testimonios de este pleito, de que se tenía noticia por carta del fiscal Haro de I. ${ }^{\circ}$ de junio de $1675 .{ }^{\text {1 }}$ o En su cumplimiento, el 30 de diciembre de i676 despachó la audiencia de Guadalajara al rey los infolios de testimonios que, ordenados en cuatro ramos, se conservan en el Archivo General de Indias y nos han permitido dar relación de este negocio. Ir I El Consejo, a su vez, actuando con gran parsimonia, no acorcló por auto hasta el 3 de marzo de 1679 , que dio lugar a la real cédula de 25 de aquel mes, aprobar lo obrado por la audiencia sobre buen tratamiento y libertad de los indios, agradeciéndole su atención a estos puntos y encargándole hiciese investigaciones sobre el de aguas y tierras, enviando los testimonios, con su informe, al mismo Consejo. ${ }^{12}$ Pero de las resultas de tal disposición, que no debió tenerlas, nada hemos sabido hasta hoy.

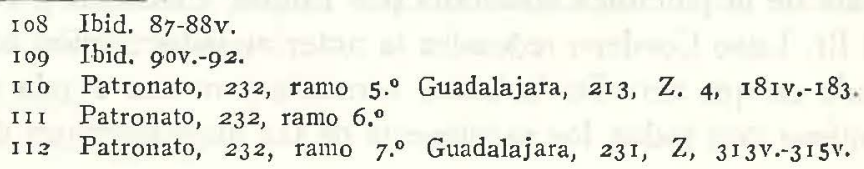




\section{Capítelo V \\ DOMINACION $Y$ DEFENSA}

LOS DOS TRJESIDIOS

La historia de las insignificantes guarniciones de Sonora $y$ Sinaloa en el siglo XVII es movida e interesante. Su actividad como fuerza de protección de los misioneros, abriendo campo at la labor de éstos; como contingentes destinados a mantener en sumisión a la población india de las propias provincias y de los territorios vecinos - la Sierra Madre, la costa seri; como verdaderas guarniciones costeras frente a un posible agresor europeo, de carácter pirático; como núcleo de desembarco en California, en fin, donde no lograrán mantenerse ni concuistar la península; todo ello hace que la crónica de estas guarniciones esté llena de incidentes heterogéneos por demás, entre los cuales, sin embargo, no deben quedar olvidados dos hechos de otro tipo: la importancia del factor militar. en la vida institucional de las provincias, y la participación frectente de gran cantidad de pobladores no soldados en las campañas y expediciones de las tropas presidiales.

La historia militar cle nuestras provincias, a lo menos en el XVII, no comprende a Culiacán, que así como pertenece a jurisdicción distinta, parece no le afectan los mismos problemas defensivos que a las otras alcaldías. Tbarra trajo consigo la jaz a la villa de San Miguel, y esa paz duraría siglos. En cambio, las dos fundaciones de Ibarra conservarían muy largo tiempo el carácter de presidios fronterizos con que nacieron el día de la conquista. La misma distinta índole de los aborígenes que hizo distintas las conquistas diversificó el color de los establecimientos europeos en 
el país. El episodio inmediato a la fundación de las villas de San Juan y San Sebastián es la sublevación de la comarca circunclante.

Los primeros pobladores españoles de Sinaloa fueron conquistadores, soldados. También eran soldados los treinta y cinco que condujo Pedro de Montoya para fundar la nueva villa que llamó de San Felipe y Santiago. ' Después de la tercera fundación y la llegada de los jesuitas, bautizados ya más de ocho mil indios, la provincia de Sinaloa se alzó en tres años dos veces. Se pensó entonces poner población con alguna fuerza; el virrey dio largas al asunto, diciendo se hiciesen primero ciertas diligencias, y el gobernador de Nueva Vizcaya, don Diego de Velasco, envió a hacerlas un teniente con veinte soldados, que se sumarían a los doce que ya se habían puesto para custodia de los misioneros. ${ }^{2}$ En 160 I se erigió presidio formal en la villa de Sinaloa.

\section{La tropa de Chiametla}

Vamos a recorrer rápidamente los breves anales bélicos de San Sebastián, que estuvo siempre desconectada, a este respecto, de la frontera setentrional. El establecimiento de tropa a sucldo alli se relaciona con el levantamiento de los acajees y jijimes de la sierra de Topia en I60I.

En 28 de enero del año siguiente, dando cuenta al conde de Monterrey de las incidencias de la campaña, escribe el gobernador Rodrigo de Vivero: "También tengo puesto en Chiametla por estos días un presidio de ocho soldados, porque se ha temido que aquellos indios convecinos de los alzados y de su misma lengua se podrían aunar con ellos, y para todo acontecimiento supera bien lo hecho a lo por hacer". Continuando pues, en esta medida preventiva pide Vivero se le envíen de México para el nuevo presidio cuatro versos y algunos mosquetes y arcabuces de cuerda y doce quintales

I Diego de Ibarra a S. M., México, 5 octubre 1583 . Guadalajara, 28.

2 Don Diego de Velasco a S. M. Durango, 8 abril 1598. Ibid. 
de pólvora. 3 Por su valor general como apreciación sobre los motivos del levantamiento aludido y de los que segunirán a lo largo del siglo citaremos aquí unas palabras del virrey, 4 quien dice que la causa de la inquietud de los acajees no es aún conocida, pero que "1o más cierto de ella y que yo 10 entiendo es fueron agravios que iban recibiendo de los españoles mineros, de cuya asistencia y beneficio de haciendas reciben por otra parte grande ganancia en st1s sustento y vestido, y en lo que más importa, que es la segruridad y perpetuidad de la conversión y doctrina, siendo estos hombres el nervio para la población de la tierra y para el amparo de los religiosos".

A mitad de este año Vivero claba por vencida la sublevación, pero consideraba conveniente mantener el presidio de Chiametla con diez hombres. ${ }^{5}$ La guerra, sin cluda, había a fectado a la provincia, pues en I604 se atribuía a ella el despoblamiento del real de Copala; ${ }^{6}$ bien es verdad que esto debió ocurrir en el rebrote de la inquietud que hubo de sofocar Urdiñola.

Es sabido que los acajees y jijimes, entre los que se pusieron los presidios de San Antonio y San Hipólito, no volvieron a suscitar problemas al gobierno de Durango. En cambio, en I6I6 se produjo la gran sublevación de los tepehuanes que tuvo dos años en pie de guerra a la provincia. Este levantamiento, que no dejó de inquictar a algunos jijimes, se extendió en fuertes ramificaciones hacia el sur, hasta Nayarit y Acaponeta, que fue incendiada. Con tal motivo hubo de acudir don Gaspar de Alvear, que dice: "me fui metiendo la tierra adentro en la provincia de Chiametla y Copala, costa del mar del Sur, donde más riesgo corrían por entonces las cosas". 7 La "Relación breve y sucinta de los sucesos que ha tenido la guerra de los tepehuanes de la gobernación de la Nueva Vizcaya desde el 15 de noviembre de I 6 i 6 hasta 16 de mayo

3 Ibid.

4 E.1 conde de Monterrey a S. M., México, 3 I marzo i602. Guadalajara, I33.

5 Vivero a Monterrey, i i junio 1602. Guadalajara, 28.

6 Relación de vecinos por Francisco Rodríguez Bayón, 9 febrero i 604. Ibid.

7 Alvear a S. M., Cacaria, I4 mayo I618. Guadalajara, 8 y 28 , 
de I6 I8", 8 narra así los hechos : "en este tiempo había saltado el fuego en algunos pueblos del mar del Sur pertenecientes al gobierno de la audiencia de Guadalajara, y tenido aviso y demanda de la dicha audiencia, en que se le pedía al gobernador socorro, no se quiso fiar de otro que de sí mismo, y así aprestándose por marzo de i6 i 7 para esta jornada con razonable número de soldados españoles y algunos indios amigos, partió a 22 del dicho mes, encaminóse primeramente a Chiametla por quietar de camino aquella provincia donde también se habían alzado muchos pueblos; fue nenester poner mucha diligencia para buscarlos, principalmente a los indios que llaman del Rincón de Zamora, por ayudarles mucho la fragosidad de la tierra y ser necesario bajar casi a gatas parte del camino, y parte descolgándose con sogas, sin poder entrar bestias, ni aun hombres del todo armados; al fin, aunque con trabajo grande, recabó el gobernador la pacificación de aquellas gentes. Desde allí fue a los pueblos de la Galicia y socorrió el presidio de Acaponeta, que le habían quemado el lugar, y ahuyentó a los enemigos de modo que en virtud de esta jornada se aseguró aquella tierra".

Veinte años más tarde uno de los combatientes de la jornada, el maestre de campo Francisco Montaño de la Cueva, contaba 9 que "habiéndose tenido aviso que estaban alzadas las provincias de Chiametla y Acaponeta, fue el dicho gobernador (Alvear) a socorrerlas, y pasando a socorrerlas, y pasando por el Rincón de Zamora, que son unas profundísimas quebradas llenas de indios rebeldes, el dicho Francisco Montaño con su compañía se atrevió a entrar en ellas, cosa que hasta entonces ningún capitán había osado, y redujo de paz a todos los indios que allí se habían recogido, con que cesó por aquella parte la guerra. Que en la Chiametla hizo varias jornadas de importancia, y todas con buen suceso,

8 Guadalajara, 8. Publicada en Bandelier, II, ro8.

9 Memorial de Montaño con carta de la audiencia a S. M., Guadalajara, 22 junio r638. Guadalajara, 9. 
sienclo el mejor haber reducido a Mateo Canelas, mestizo muy nombrado en aguella tierra, con que se consiguió su pacificación a costa de grandes trabajos y riesgos que se padecieron".

Con estas notas hemos incorporado a la historia de Chiametla tres personajes - el gobemador Alvear, único que la visitó en todo el siglo y el primer tercio del siguiente; el entonces capitán Montaño, y el jefe de saltendores que debía ser Mateo Canelas-- y tull episoclio: la pacificación del Rincón de Zamora. Echamos de menos una alusión al presicio de San Sebastián, que no parece por parte alguna. El obispo Mota y Escobar dice que el conde de Monterrey, que suprimió la Real Caja que había tenido la villa, dejó también sin paga a los vecinos que la cobraban del rey a título de soldados, ro

Sin embargo, aunque concluida la guerra de los tepehuanes se llevó a cabo una reducción cle los efectivos militares de toda Nueva Vizcaya - misión que se enconnendó precisamente a Montañosulssistió o volvió a erigirse el presiclio de Chiametla, mandado por el alcalde mayor de San Sehastín en virtud del acnerdo de otorgar a una misma persona los títulos de capitán y de alcalde expedidos respectivamente por el virrey y por: el gobernador, ir procedimiento que se practicaba de igual modo en Nueva Vizcaya para los presidios de Acaponeta y Mazapil. Chiametla era por entonces 11no de los cuatro presidios de la gobernación, siendo los otros los de Sinaloa, San Hipólito y Santa Catalina Tepehuanes. La "Relación de las alcaldías mayores" elaborada hacia i640 indica que el presidio de San Sebastián tenía ocho soldados que colraban 450 pesos antrales, y su capitán-alcalde mayor, 6oo. ${ }^{\mathrm{r} z}$ Con nueve hombres, era éste el más reducido presidio de Nueva Vizcaya, pues Santa Catalina tenía dieciséis: San Hipólito, diecisiete, y Sinaloa cuarenta y siete. Aquella minúscula fuerza aún se redujo posterior-

I0 Mota, 80-00.

i B Biblioteca Nacional de Madrid, M'ss. 3.048, fols, Ior-i 63.

I 2 Ibid. Mss, I 8.684 , fol. $\mathrm{S}$. 
mente, pues en I67I sólo consta de seis soldados y un capitán. ${ }^{\mathrm{I}} 3$ No sabemos cuándo se produjo la extinción de este presidio, del que no hallamos noticias más adelante y sólo nos queda como indicio de su permanencia la continuidad de los nombramientos hechos por el virrey de capitanes del presidio de la villa de San Sebastián Chiantetla, siendo el último que nos es conocido el de don Juan de Isla, debido al virrey Paredes, en 5 de octubre de I684. ${ }^{14}$

Presidio y misión en Sinaloa

Según Pérez de Ribas, en I596, los escasos pobladores de la villa de los Dos Apóstoles reclamaron al gobernador de Nueva Vizcaya y al virrey, a raíz de la muerte del $\mathrm{P}$. Gonzalo de Tapia, para que se pusiese una escolta que protegiese a los misioneros en aquella provincia. Y en ese año llegaron de Durango el capitán Alonso Díaz, con título de teniente general del gobernador, y veinticuatro soldados. ${ }^{15}$ Algo más adelante asienta el historiador jesuita que al tiempo de escribir él los "Triunfos", la fuerza del presidio era de cuarenta y seis soldados. ${ }^{16} \mathrm{E} 1$ cálculo del P. Pérez debe ser que a los veinticuatro que cita, más el capitán y el caudillo -Díaz y Hurdaide - , se sumaron diez soldados más cuando Hurdaide fue nombrado capitán, y otros diez años adelante, al ampliarse las misiones. ${ }^{17} \mathrm{Ya}$ hemos aludido al texto en que el gobernador Velasco da noticia de treinta y dos hombres, de los que doce estaban ya en la villa cuando él envió los otros veinte.

Pero sin duda es de mayor interés que esta diferencia, la serie de reflexiones que Pérez de Ribas desarrolla en tres capítulos

I3 Certificación adjunta a carta de Haro Monterroso a S. M., Guadalajara, I9 marzo I67I. Guadalajara, II.

I4 Escribanía, I8 I B. fols. 67-69v.

I5 Pérez de Ribas, Trinufos, I, I86.

I6 Ibid. I93.

I7 Ibid. $21 \mathrm{I}$. 
- XII al XIV- para mostrar que la utilización de la fuerza de las armas no contravenía al espíritu ni a la letra de la doctrina evangélica que los misioneros predicaban. "Obligado me hallo a tratar y exaninar en este lugar. tula clificultad y duda de importancia". Pero para el P. Andrés, precisamente para el hombre que veía con pleno optimismo las perspectivas de nina fácil conversión de los indios, no había tal duda ni contradicción, considerando la erección de los presidios medio justo y proporcionado al tiempo, lugar, personas y obras que se pretendian. Puesto que los soldados sólo se querían para evitar los disturbios que promovían algrt1nos apóstatas, para guardar la paz que permitiese la libre predicación de la fe, para defender de sus enemigos a los pueblos que se convertían y acogian a la amistad y protección del rey de España y para castigar a los delincuentes. Que en ninguna manera estaba fuera del pensamiento cristiano el pretender los Padres aquel auxilio, y que por consiguiente el gasto que el erario tenía en la guarnición era justo y glorioso. Pérez de Ribas no disimula el carácter de los soldados de I600, "cuya libertad, orgullo y trato strele inquietar a estas nuevas gentes con sus altiveces y licencias que se toman, que hacen más daño que provecho..., pero puesto en una balanza esos tales inconvenientes y en otras las conveniencias que de los presidios dejamos escritas, éstas sobrepujan incomparablemente a todos los inconvenientes contrarios". Ta razón de más peso, a juicio del P. Pérez, sobre el particular consistía concretamente en el efecto que en los indios causaba ver a los valientes españoles hincarse de rodillas en la Misa, adorar el Santísino Sacramento; ver la reverencia con que trataban a los Pacles, verlos confesarse, comulgar y adorar las santas inágenes. "En particular. vi al valeroso y piadoso capitán Diego Martínez de Hurdaide (de cuyo celo de la salvación de estas almas va adelante un poco escrito) que ejercitaba estos actos de religión y no pocas veces se ponía a vista de ellas a confesar de rodillas a los pies del sacerdote, y después con mayor reverencia recibir la Sagrada Comunión, a cuyo 
ejemplo hacían 10 mismo sus soldados. Y a todos 10 dio el valeroso Cortés, conquistador del Nuevo Mundo...".

He aquí, pues, establecido y justificado el presidio del capitán Alonso Díaz en Sinaloa, reducidísima fuerza de tres o cuatro decenas de hombres frente a los veinte o treinta mil que podrían levantar las naciones indias si se coligasen contra ellos. Claro que los españoles también utilizaban an número proporcionado de auxiliares indios, que por sí solos jamás aconeterían las cmpresas a que entrahan gobernados por los espanoles. "También se rebe atender a que el soldado armado y sobre 111 caballo de armas es un castillo incontrastable a las flechas para defenderse. $Y$ si la batalla es en campaña rasa y donde el soldado a caballo puede acometer y dar alcance al enenigo, lo puede ofender mucho y desharatar". Cuando el encuentro era en terreno montañoso, los jinetes se situahan en algún punto elevado, y protegidos por el fuego de sus arcabuces, actuaban los indios a pie. Soldados y caloallos de armas eran, por lo visto, todavía a mediados del XVII la principal fuerza y defensa. Los caballos, cargados con sus pesadas corazas, dobles ctreros de toros, eran llevados del diestro y los españoles no los montaban hasta el momento de entrar en batalla. Por st1 parte, también los enemigos habían hecho alardes de arrojo temerario: había quienes se arrojaban debajo del caballo para desjarretarlo, y quienes se juntaban para hacer caer uno de estos animales tirándoles de la cola; otras veces el caballo se inutilizaba en piezas $\mathfrak{t}$ hoyos. En tales lances, caballo y caballero corrían grave peligro, inmovilizados por los arreos defensivos. Olssérvese, por último, la total omisión por el historiador jesuita de cualquier alusión a la presencia de indios enemigos montados en zona como Sinaloa y Sonora, un siglo después de la conquista de Nuño de Guzmán, y después que Mota y Escobar nos ha dicho que Culiacán fue un tiempo famosa en caballos. En cambio dirá que. Hurdaide obsequiaba a los caciques regalándole potros, "y ellos estiman mucho dar una carrera en un caballo, aunque sea a pelo, y esto les es de gran gusto y entretenimiento, aunque no tengan 
otro freno con que gobernarlo que una cuerda que les atan a la barba". ${ }^{8}$

E1 25 de enero de 1595 habian llegado los cloce primeros soldados al mando de Alonso Díaz. Io Sus primeras diligencias sirvieron para pacificar a los guazaves, no sin que mediase $u n$ encuentro de quince españoles con doscientos indios, y para poner en fuga al asesino del P. Tapia, Necaveva, que se refugió entre los zuaques, que se atrevían a asaltar la villa y robar y matar bestias, y luego entre los tehnecos, que lo entregaron a Hurdaide, entonces caudillo del presidio, quien to hizo ajusticiar. 20

\section{Hurdaide, Capitán vitalicio}

Criollo nacido en Zacatecas, hijo de padre vizcaíno, Hurdaide llegó a Sinaloa con la primera escuadra del capitán Díaz. Fute éste quien hacia 1599 le envió a México a dar cuenta al conde de Monterrey del estado de la provincia. El conde, atendiendo a la avanzada edad de Alonso Díaz, le concedió el retiro y nombró a Diego Martínez de Hurdaide jefe de la guarnición de la villa, que con diez soldados más pasó a tener treinta y seis hombres. Los Padres se entendian directamente con el virrey y éste disponía de la tropa y nombraba capitán sin contar con el gobernador de Durango; sin embargo, Hurdaide se reconocía subordinado a él como justicia mayor de Sinaloa. Guerrero experimentado a las, órdenes de Urdiñola en las fronteras de Nueva Vizcaya y Nueva Galicia —en Guanaveci, Santa Bárbara y Mazapil--, su primera gestión fue para poner en calma a los guazaves, nutevamente inquietos, logrando definitivamente la paz en el río de la villa. Los papeles en que imprimía en cera su sello - -quizás de aquí vinieran el nombre de "sellos" que más tarde se le dio a los mandamientos de los alcaldes- servían más adelante de salvoconducto

I 8 Ibid, 2 I 6.

I9 Decorme, II, I62.

20 Pérez de Ribas, I, zor-208. 
en cien leguas de distancia del presidio: éste fue el fruto de un cuarto de siglo largo de trabajos al frente de las armas de la provincia, pues murió en los primeros meses de 1626.

Su primera gran empresa, mezcla de astucia, valentía y rigor, fue el castigo de los indios zuaques. ${ }^{21}$ Someticlos estos enemigos, quedó abierto a los misioneros el camino al río que más adelante se llamó del Fuerte, y vengada la destrucción de las primeras villas de Carapoa y Sinaloa.

Seguidamente llevó a cabo una expedición que le encargó el conde de Monterrey a la sierra de Chínipas en busca de yacimientos mineros que se suponía existían allí los indios de la sierra le prepararon una emboscada en un paso angosto y lograron tenerlo aislado de su retaguardia dos días, al cabo de los cuales hubo de emprender la retirada, concluyéndose la campaña con el castigo de los sinaloas del curso medio del río Fuerte que le habían traicionado. ${ }^{22}$ La próxima incursión, hecha en defensa de los aliados ahomes, le llevó en i6or a un nuevo encuentro con los zuaques de Mochicahui unidos a los sinaloas, y a dar una sorpresa a los tehuecos, que habían usurpado ciertas tierras a los ahomes. De regreso de esta entrada cortó Hurtaide el cabello a los zuaques como castigo a sus veleidades, haciéndoles además entregar algunas mantas o armas como pena pecuniaria. ${ }^{23}$

Al cabo de estas y otras facciones, zuaques, tehuecos, y sinaloas acudieron a la villa a pedir misioneros, y siendo para ello preciso recabar previamente la autorización del virrey, marchó Hurdaide a México por segunda vez, acompañado de algunos de los caciques solicitantes. Este hecho marcó realmente el principio de la expansión de la provincia, hasta entonces contenida en el calle del río de Petatlán. El virrey dio su aquiescencia para la entrada de los Padres al río de Carapoa, y envió con Hurdaide

\footnotetext{
2 I Ibid. 217-224.

22 Ibid. 227-228.

23 Ibid. 233-237.
} 
otros dos jestitas, uno de los cuales cra Pérez de Ribas. ${ }^{24}$ E1 capitán hubo de empezar por reducir a algunos pueblos ya convertidos, pero que a la nenor incidencia se amotinaban y alzaban a los montes, pero pocos años después, entre revueltas y peligros, las misiones se habian consolidado y Hurdaide hacía construir nuevo presidio en el Zuaque, que desde entonces ionó el nombre que conserva de río del Finerte: la guarnición se iba desplazando al norte conforme avanzaha la fronteta. El presidio, que se llamó de Montesclaros, fabricado entre 1610 y Iot2, serviría para empezar a someter a los mayos y yaquis y fue, con el timpo, origen de la villa de líl Finerte. Se edificó junto al mplazamiento de la arruinada villa de Carapoa fundada por Ibarra; era de adobes, y podía contener en su interior la caballacla de los soldados, $y$ presentalja cuatro bastiones en sus esquinas.

\section{Hurdaide en ei, Mayo y tei, YaQUi}

Hacia I6o\$ tenía el capitán de Sinaloa concluido por escrito un convenio de paz y alianza of ensiva-defensiva con los mayos, la más numerosa nación india de la costa, enemiga hasta entonces de los tehuecos, ya evangelizados, y que lo segúa sienclo de los yaquis, que fueron los más aguerridos adversarios de Hurdaide. El establecimiento de misiones en los pueblos de mayos tenía lugar en I6I4, esto es, a los diez años del ingreso de los jesuitas en el río del Fuerte. El virrey Guadalcázar dio su consentimiento a este segundo paso hacia el norte. ${ }^{25}$

Hurdaide había hecho el trato con los mayos con su cuenta y razón. De años atrás tenía una deuda pendiente con los yaquis, que habían venido siendo el refugio de todos los descontentos de los pueblos de misión. En I608 hizo el capitán dos incursiones al Yaqui: la primera, en son de paz, fue un fracaso; la segunda, en que fue con cuarenta soldados y dos mil auxiliares, concluyó

24 Ibid. $237-239$.

25 Pérez de Ribas, II, 9-I 2. 
con el regreso de Hurdaide después de un sangriento combate de sol a sol. ${ }^{26}$ A principios de 1609 , con cincuenta soldados - gracias al refuerzo de alguna gente de Culiacán-- y cuatro mil auxiliares, sufrió un serio descalabro, pues esparcida la nueva de su muerte en el primer encuentro, todo el ejército se deshizo, y él salvó la vida gracias a un ardid. ${ }^{27}$ Pero los yaquis, aunque victoriosos, querlaron tan impresionados de la fuerza de los españoles y tan temerosos de las represalias, que se aprestraron a iniciar negociaciones de paz, negociaciones que condujeron a la celebración de un tratado en la villa de San Felipe y Santiago el 25 de abril de I6Io. ${ }^{2}$ La frontera podía dar un nuevo salto al frente y en efecto, en I6r7, a sólo tres años de la llegada de los misioneros al Mayo, pasaba Pérez de Ribas, con licencia del mismo marqués de Guadalcázar, al Yaqui, al pueblo de Cocorit. ${ }^{29}$

Por estas fechas habían sucedido otros dos acontecimientos de importancia para Sinaloa: uno, la presencia de los pechilingues en sus costas, los viajes de Iturbi en busca de las perlas del Golfo, y la comisión dada al capitán de San Hipólito, Bartolomé Juárez para ir en busca de la nao de Filipinas; en conpendio, ya henos narrado estos sucesos en otro lugar. El segundo acontecimiento fue la sublevación de los tepehuanes en I6I 6 , al otro lado de la sierra. Este movimiento, segunda gran convulsión de la atormentada historia de Nueva Vizcaya, significó para las alcaldías costeras, sobre el cierre temporal de los caminos transversales, un fundado riesgo de contagio de los indios cristianos con los sublevados. Emisarios tepehuanes bajaron de la sierra buscando la alianza de los vecinos chicoratos, del curso superior del río de Sinaloa, que hacía años daban muestras de inquietud. Acudió luego Hurdaide y puso una pequeña guarnición de siete soldados y setenta

\footnotetext{
26 Ibid. 66-69.

27 Ibid, 69-73.

28 Ibid. 82. Decorme, II, 326.

29 Pérez de Ribas, II, 84 y 89.
} 
atxilitres en Tecuchiaja, que se convirió en puesto avanzado de defensa contra los alzados y preservó la paz en Sinaloa. 30

\section{POR LL, YaQUL, TIERRA ADENTRO}

El Yaqui es lit gran vín de Sonora. Y con la conversión de los yaquis, L-Iurdaide y los Padres halian puesio pie, sin saberlo, en el umbral de una provincia distinta. Los yajuis ocupan el curso inferior de su río. Corriente atriba los pimas bajos se extienden hasta la sierra; por los alluentes de la orilla derecha, hacia el norte, se asientan los ópatas, y al noroeste, saltando al río de Sonora y al de San Miguel, otros pimas ván bordeando el desierto seri y cerrando la Opatería. Del Yaqui por la costa no se puede avanzar: el río Matape sólo está poblado hasta la mitad de sil curso; el Sonora, hasta litemosillo, que en su día se llamó Pitic, y eso no antes de 1748 . Es inútil seguir aún más al norte y al oeste: ni las condiciones geográícas, ni la casi inevistente población permiten pensar en otra cosa que pequentas rancherías nóviles, primero de seris, luego de pimas altos, distanciadas por desiertos, arenales y mirismas, hasta el Colorado.

La ruta del Yaqui se impone por sí sola, e históricamente así sucedió. La marcha "contra corriente" fute mucho más fácil de to que se hubiera podido suponer. Hay que decir que Intade era aliado de los pimas bajos descle la misma época en que había acogido a los mayos bajo la protección del rey de España: la belicosa condición de los yaquis contra todos sus vecinos lo había hecho casi inevitable. Cuando Hurdaide visitó a st1s aliados nebomes en I6I4 los encontró muy pacíficos y laboriosos, criadores de gran cantidad de gallinas de Castilla --esa crianza que prevenían los títulos de los alcalcles mayores-y deseosos de recibir a los misioneros. Muy poco después los caciques pimas viajaban hasta la villa de Sinaloa - la "paz hispánica" aseguraba los caminos-

30 Con motivo de la sublevación, antes de entrar al Yaqui, tuvo Pérez de Ribas que dar un rodeo desde Durango a Sinaloa. Ibid. 85. Decorme, II, 192-I93. 
para reiterar estas instancias; los mismos yaquis cruzaban confiados las tierras de sus enemigos de ayer para acudir a trabajar a las minas del otro lado de la sierra. Incluso varios centenares de pimas se trasladaron sus viviendas a Bamoa para estar pronto cerca de los Padres. Establecido el P. Pérez de Ribas entre los yaquis, la cristianización de los pimas bajos comenzó casi simultáneamente, en el mismo $16 \mathrm{I} 7{ }^{3 \mathrm{I}}$

Hurdaide tuvo pronto nueva ocasión de intervenir. En I6I9, cuando se establecían las misiones de Buenavista, Conurripa, Suaqui Grande y Tecoripa, tuvo que llevar a sus hombres y mil auxiliares contra Matape, fortaleza de los aibinos semisalvajes, en un encuentro sangriento pero afortunado. ${ }^{2}$ Después de esto, el camino de Sonora estaba definitivamente abierto, aunque Perea tendría que sofocar un conato de rebelión por parte de algunos nebomes.

El piadoso y justiciero capitán Hurdaide debía estar, pasados los cincuenta años de vida, muy gastado por las fatigas de la frontera. Su última campaña le llevó de nuevo a la sierra, a las orillas del río del Fuerte, y donde ya se asentaba el de Carapoa - Montesclaros. En 1625, el cacique Jocopillo se convirtió en adalid de uno de los innumerables y típicos novimientos independentistas y antieuropeos contra el reloj de la historia. Se le unieron otros jefes del contorno y todos juntos destruyeron la misión de Vaca, mataron a varios indios cristianos, e incluso se comieron a varios mensajeros del capitán. Hurdaide tuvo que salir al frente con cuarenta y ocho soldados y quinientos indios, y los halló empeñolados, refugiados en lo alto del cerro de Barrabás; los sitió tenazmente durante treinta días, al cabo de los cuales, recibidos diez soldados y dos mil auxiliares de refuerzo, decidió el asalto que le dio la victoria: ciento cincuenta muertos y cuarenta prisioneros enemigos fue el balance de aquella jornada, y los cautivos fueron ajusticiados o condenados a trabajos forzados. Hur-

3 I Pérez de Ribas, II, I 5 I.

32 Ibid. I62-164. 
daide envió emisarios que informasen del suceso al gobernador de Nueva Vizcaya, Mateo de Vesga, 33 y antes de un año fallecía en la villa de San Felipe, desputés de haber presenciado y protagonizado, de I595 a I626, la fantástica expansión que permilía a la villa un tiempo amenazada por los zuaques dentro de sus muros, señorear del Mocorito al Yaqui gracias al esfuerzo, arrojo y abnegación de un centenar de soldados, misioneros y vecinos.

Pedro de Perea, capitán joe Sinaloa

Murió don Diego Martínez de Hurdaide cuando ya venía caminando para hacerse cargo del mando del presidio el capitán don Pedro de Perea, "alentado y animoso soldado" andaluz, de la familia del virrey de Nueva España. 34 Enterados los indios del fallecimiento del uno y de la 1legada del otro, acudieron luego a cumplimentar y dar la obediencia a Perea, a tiempo, sin embargo, en que los nebomes empezaban a inquietarse con ánimo de sacudir y rechazar la reciente dominación de los españoles, coligándose para este fin con otros indios aún gentiles y no sometides, con los que intercambiaban cañas de tabaco como señal de la alianza y aviso del próximo levantamiento. De todo tuvo noticia inmediatamente Perea, y hechas las diligencias oportunas, prendió e hizo ahorcar a un indio de nación distinta a la de los nebones, complicado en la conjura. Ocurrieron luego amenazas y ataruues a los Padres, y siguió la quema de varias iglesias, y hubieron de acudir los soldados con su escolta de auxiliares a correr la tierra, perseguir a los levantiscos, apresar algunos y hacer varios castigos, hasta que la nación quedó sosegada. ${ }^{35}$

Luego hubo Perea de intervenir en la sierra, en la región de Chínipas, donde tuna misión de jesuitas empezaba a afianzarse, pero donde el apóstata Cobamei impulsó un movimiento de rebel-

33 Bandelier, II, I46-I52,

34 Pérez de Ribas, II, I52-I53.

35 Ibid. I 69. 
día que el I. ${ }^{\circ}$ de febrero de 1632 costó la vida a los Padres Pascual y Martínez. Las fuerzas de Sinaloa se pusieron en camino para Chínipas, donde los guazapares y varohios andaban alzados por los montes : los auxiliares de Perea ${ }^{36}$ dieron buena cuenta de las dos terceras partes de ellos. Al mismo virrey marqués de Cerralbo le pareció excesivo el castigo. 37 Los cuatrocientos que todavía se rindieron fueron agregados, como los chínipas, a los pueblos de Toro y Vaca, en Sinaloa. En los años siguientes, escuadras de Sinaloa visitaron con frecuencia la sierra para mantener la quietud de los indios que la habitaban, que se mantenían al margen de la vida de las misiones.

Había por estas fechas en Sinaloa cuarenta o cuarenta y cinco soldados. Según Juan López de Vicuna, el capitán residía con treinta hombres en el fuerte de Carapoa, y otros diez mandados por el caudillo hacian guarnición en la villa de San Felipe y Santiago. Tenía el capitán dos mil pesos de salario y, según nuestro informante, podia ganar diez mil más dedicándose a comerciar en el presidio. Ochocientos pesos ganaba el caudillo. Y a juzgar por sus noticias ya en $163_{2}$ andaban desgajados los oficios de capitán de la guarnición y de alcalde mayor de la provincia, pues éste, nombrado por el gobernador de Nueva Vizcaya, percibía sólo cuatrocientos pesos sobre el producto de las salinas de la costa de su jurisdicción. 38 Pagóse al principio a los soldados 450 pesos anuales en plata, pero hacia I625 - hace doce o catorce años, se expresan los jesuitas en I639- resolvió el virrey en Real Acuerdo que en vez de percibirse aquellos miles de pesos en México, los abonase en Sinaloa un pagador nombrado a este fin, y que entregaría a los soldados una parte de sus haberes en reales, y el resto en ropas y géneros, sobre cuyos precios tendría él un margen de beneficio. 39 Las noticias, aun tratándose de un mismo

36 Decorme, II, 224-225.

37 Asi lo eseribe Porter a Guajardo en Sinaloa, ro julio I650. Guadalajara, 29.

38 Segunda relación, fols. 2ir,v. Guadalajara, 3rз.

39 Informe de la Compañia al virrey, México, I2 setiembre 1638 , fols. 3-22v. Guadalajara, I38. 
punto, varían segín los informantes. Para don Francisco de Bustamante, no tenía importancia la forma en que se pagase a los soldados, pero que en Sinaloa no había tratos ni de qué hacerlos. Ei es de los que dicen que habia cuarenta y seis soldados - cuarenta y cinco y un caudillo-_ y que asistían "como en plaza de armas, en la villa", omitiendo toda altusión al Futerte; y él, en fin, ejerció al parecer simultáneamente la capitanía de la tropa y el mando civil de la provincia, habiendo tenido que reconstruir las casas reales de San Felipe y Santiago, arrasadas en 1634 por una crecida del rio. 40

Por aquellas fechas, otros autores hacen cierta la descripción de los soldados y sus armas que ofrece Pérez de Ribas. López de Vicuña, proponiendo los usos de tierra adentro para las tropas tropas que se deberían enviar a Californias, habla de dobles coletos de cuero, caballos con armas también cle cuero, climales o adargas pequeñas de cuero crudo con que defenderse de las flechas, cascos y sobrevistas, arcabuces de pedernal "que llaman en Castilla escopetas". Los Padres ponen énfasis en la descripción de las flechas envenenadas que utilizaba el adversario, y que "con yerba, irreparable de muerte cuindo es fresca, annque sea la herida en el extremo del pie", obligaban a los soldados cuando entraban en campaña a valerse de armas defensivas hasta en las manos. $4^{\mathrm{T}}$

\section{Perea ocupa Nueva Andalucía}

En I640 se produce un fenómeno extraño sobre el que ya hemos llamado 1a atención. Don Pedro de Perea - a quien algunas fuentes siguen llamando capitán de Sinaloa- capituló con el virrey Cadereita el poblamiento del país al norte del Yaqui, al que en recuerdo de su tierra quiso llamar Nueva Andalucía. Y entre sus obligaciones como capitulante entraba la de sostener por su cuenta veinticinco soldados, al parecer de los mismos que el rey

40 Informe de Bustamante, México, 28 febrero I639, fols. $57 v .65 \mathrm{v}$. Ibid.

4 I Informe de la Compañía, cit. 
pagaba en Sinaloa. Perea, volviendo de México, entró a sin nuevo mandato en I64I, desde Parral: su gestión en lo que se llamaría Sonora fue breve y complicada.

Don Pedro de Perea, que se asentó en Bananichi, en el valle de Sonora, comenzó disgustándose con el P. Figueroa, que lo habia acompañado en su viaje por la Tarahumara, y llamando misioneros franciscanos para ponerlos al frente de las misiones ópatas y pimas. Como a poco de su entrada le hicieron devolver a Sinaloa los veinticinco soldados de cue había dispuesto, Perea pasó a Nuevo México para traer pobladores - trajo efectivamente doce- y para conseguir del superior Fr. Tomás Manso el envío de cinco franciscanos, que vinieron a establecerse en la más reciente frontera del norte. Eran estos Padres Fr. Juan Suárez, que atendía a las misiones de Arizpe, Chinapa y Bacuachi y actuaba como superior. Otro establecido entre los potlapiguas, bavispes y baseracas. Un tercero en Guazavas, Oputo, Techicodeguachi y Batepito. En Teuricachi, Cuquiarachi y Teras misionaba Fr. Juan de San José. Y el quinto y último padre dedicó sus afanes a Cucurpe y Toapa, a donde ya habían llegado los jesuitas. En los cortos años que estos frailes residieron en Sonora bautizaron unos siete mil indios. 42

Protestaron naturalmente los de la Compañía de la intronisión que la orden hacía en terrenos en los que ellos estaban realizando la introducción del evangelio, aunque hoy pueda parecer extraño que se produzcan competencias por un motivo así. Pero en la época parecían legítimas semejantes reclamaciones, y como tales fueron atendidas, precisamente por quien mejor podía comprenderlas, el obispo-virrey Palafox, que en esto - pese a su fama- estuvo de parte de los jesuitas y favoreció su demanda. También su sucesor, el conde de Salvatierra, falló a favor de la Compañía. 43

Entretanto, Perea, poniendo desafortunadamente en práctica

42 Pérez de Ribas, II, 239. Mange, 340, 341, Decorme, II, 263, 332, 362-365.

43 Decorme, II, $363-365$. 
ideas y procedimientos bien distintos y aun contradictorios a los habituales, llevó con gran tropa a los franciscanos a tierras de los indios himeris - pimas altos, en el río Magdalena- intentando abrir allí misión. Pero acquellos indios, rechazando to que se presentaba como tna invasión, lo atacaron en los pasos estrechos que ofrecía el terreno, obligándole a retroceder aprestradamente. Su terquedad, sin embargo, le llevó a intentar repetir la tentativa - pese a una grave enfermedad padecida en el intervalo- y esto le hizo morir en Tuape, el 4 de octubre de I645, a mitad de camino de su objetivo, 44 días antes de que diese el virrey Salvaticrra la orden para su relevo en aquel manclo, en g del mismo octubre. 45

Con todo, Perea había logrado el poblaniento de Sonora por los españoles; había hecho así una conquista inapreciable para las provincias situadas más al sur y para toda la frontera de Nueva España en general, y había por tanto vinculado su nombre incliscutiblemente a la historia de aquella provincia.

La gestión de Perea, por otra parte, se extendió también por el rumbo opuesto, desde el mismo valle del río de Sonora, a los cuatro valles de los guazavas, ópatas y jovas del curso inferior del río de Bavispe, a los que entró con ciento cincuenta españoles y dos mil anxiliares talándoles sus milpas para obligarles a aceptar la paz. ${ }^{46}$

Perea estableció, por el interior de Sonora, las posiciones más setentrionales de españoles en la zona durante medio siglo, y posteriormente sólo avanzarían sobre esos límites poco más que algunos puestos militares. En su tienpo, por tanto, quedó esbozaclo lo que luego sería frontera de Sonora, en la divisoria de los ópatas con los sumas en el río de Teuricachi o de Santa Bárbara, afluente del de Bavispe.

Muerto el fundador de Sonora, y resignándose a retirarse del

44 Ibicl.

45 En 9 de octubre de 1645 encomendó el virrey el gobierno de Sonora al entonces capitán de Sinaloa, don Juan de Peralta. Atondo a Porter Casanate, Sinaloa, 20 nowiembre I 650 . Guadalajara, 29.

46 Decorme, II, 369. 
país los franciscanos, hallaron los jesuitas expedito el camino para su actividad: los himer-is, los guazavas y aun los sumas se prestaron sucesivamente a mantener relaciones amistosas con los Padres y a recibir misioneros en sus pueblos. La última nación citada celebró las paces en Oputo en I65 I,47 fecha que es casi un hito, desde la primera salida de Alonso Díaz de la villa de Sinaloa. Sonora estaba prácticamente ganada.

Porter, California y la rebelión tarahumara

A despecho de los medios insignificantes puestos a contribución por los sucesores de Cortés, durante medio siglo Sinaloa, la aislada villa fronteriza de Ibarra, había presenciado y protagonizado una expansión prodigiosa. La aparente paralización relativa que se produce en la segunda mitad de la centuria no se explicaría si no se tuviese en cuenta: que más allá de los ópatas, como más al noroeste de los yaquis, se hallaban pueblos - sumas, janos, apaches, seris, etc.- difícilmente asimilables al mundo y moldes de los europeos; que la fase siguiente a la etapa de Hurdaide y Perea había de ser, según todas las probabilidades, antes de permitir un nuevo movimiento expansivo de cualquier tipo, una fase de consolidación de las provincias ganadas, de "relleno" interior del territorio, de puesta en explotación de las riquezas que Sonora precisamente acababa de ofrecer a los españoles; finalmente, y de manera destacada, que Sonora constituye después de Perea, durante una treintena de años, una avanzada casi totalmente aislada del resto del Imperio, puesto que salvo su conexión con Culiacán, verdadero nudo de comunicaciones de la costa, no tenía más enlace al otro lado de la sierra que el muy débil cordón de misiones franciscanas que empezaba en Casas Grandes y, por tierras de los sumas, mansos y conchos, permitía enlazar con Parral, y aun esta

47 Ibicl. 370. Los sumas debían ser un grupo atapasco también llamado "jano", "jocome" o "manso" y finalmente "apache chiricahua". Forbes, Jack D.: The janos, jocomes, mansos and sumas indians. N. M. H. R., 1957, 4, 319-334. 
linea no comenzó a cerrarse sino después que en i 650 se establecieron los primeros misioneros de Grtadalupe del Paso y que en los años sesenta, como sabemos, se creó la alcalclía mayor en Casals Grandes para apoyar la misión que había comenzado aquí.

La inmensa zona comprendicla entre Sinaloa y Sonora, Casas Grandes, E1 Paso y Parral escapaba todavía al dominio español. Recuérclese que en I64 Perea había intentado asegurar t11 camino de Parral a Sonora a través de este territorio; ocho años más tarde, todavía decía Guajardo Fajalrdo de los tarahumaras que era "gente que jamás había teniclo noticia del Evangelio, ni nós comunicación con los españoles que haber unos años antes pasado por sus tierras el capitán Don Pedro de Perea a poblar la Nueva Andalucia”. 48 Y don Gregorio López de Dicastillo podrá aún aludir al camino de ciento treinta leguas, a través de infieles, que conducía de Ostimuri a Parral. Sobre esto y para apreciar mejor la dificultad de entrar a la Sierra Madre chihuahnense, baste recordar que en i.64 8 se producía el peligroso levantamiento de la Tarahumara baja, cuyos efectos en Sonora expondremos más adelante.

Entretanto, Sinaloa había pasado a convertirse en plataforma de las tentativas para la ocupación de la frontera península de California. Un suceson de Perea en aquella alcaldía, don Luis Cestín de Cañas, llevó a cabo la primera tentativa en junio de I 642, por orden del virrey Salvatierra, con una fragata y una escuadira de presidiales. 49 La expedición, que visitó la isla de San José y el puerto de La Paz, salvo por el rescate de perlas, resultó baldía, porque, como acreditarian las empresas posteriores, ni el país ni. sus habitantes abrían posibilidades para una fácil conquista, misión, ni población.

Sin embargo, los viajes a través del mar de Cortés contintaron, incluso con mayor empuje, por móviles misionales y estratégicos -con objeto de impedir la caída de la península en manos de los piratas que hacía tiempo se dejaban sentir en açuellas aguas

48 Guajardo a S. M., Parral, 3 mayo I649. Guadalajara, 29.

4) Mange, I37. Vellegas, I $54-155$. 
con evidente riesgo de la ruta que enlazaba Manila con Acapulco. Por eso en I6 42 se concedió aquel descubrimiento y conquista al gran marino aragonés don Pedro Porter Casanate, que envió una fragata a California en 1644 , y luego, personalmente, hizo en $16_{4} 8$ aquel viaje con naves construidas en Sinaloa, cuyo gobierno le había sido concedido. ${ }^{\circ}$ California significó, pues, para la tropa de Sinaloa, un nuevo campo de actividades.

El cese de Perea en Sonora en I 645 había dejado planteado a su vez, una serie de problemas. Según el mandamiento de Salvatierra, el entonces capitán de los presidios de Sinaloa y teniente de capitán general por el virrey don Juan de Peralta asumió el mando militar de Nueva Andalucía, del que tomó posesión el i i de abril de I646. De Peralta recibió Porter el mando, y en virtud de órdenes de México practicó el almirante la visita de Sonora en I650, con objeto de mantener a los indios en paz y sujeción. $\mathrm{Y}$ a se ha dicho, hablando de los asuntos institucionales, cómo el gobernador de Parral protestó de los títulos de teniente de capitán general que los virreyes daban a los capitanes de Sinaloa - títulos, no obstante, que todos habían tenido, desde Alonso Díaz- por cuanto esto significaba a su juicio la dependencia directa de la guarnición de Sinaloa del virrey. Los roces se iniciaron ya de manera inevitable con ocasión de la reluelión de los tarahumnaras bajos comenzada el día del Corpus de i648.

"Estando en la pacificación de la provincia de la Tarahı1mara -dice Guajardo Fajardo-, 5 ${ }^{\text {I }}$ despaché por justicia mayor y capitán a guerra de la Sonora a Simón Lasso de la Vega con orden de que por aquella parte hiciese frente al enemigo, y también

50 Venegas,, I56-I57. Portillo, Alvaro del: Descubriniento y expediciones en las costas de California, Madrid, I947, dedica a Porter el Cap. VII, págs. 245-290, y muestra que Porter no estuvo presente en la navegación de $\mathrm{r} 644$, que encomendó a Alonso González de Barriga, quien al parecer no tuvo ocasión de acompañar al galeón de Manila, como pretende Venegas. Son sumamente valiosos los apéndices XIV al XX de esta misma obra para conocer los propósitos y realizaciones de Porter en orden a la conquista de la península.

5.I Guajardo a S. M., Parral, i9 enero I650. Guadalajara, 29. 
se la di para que por ella reconociese toda la tierra que pudiese y la fuese reduciendo al servicio de V. M., en que ha puesto el cuidado y diligencia que se verá por los autos que con ésta remito a V.M., y es cierto que se aventajaran los progresos a no tener los impedimentos y contradicción que hace el capitán del presidio de Sinaloa", que pretendia tener jurisdicción militar sobre Sonora, como el mismo Porter declaraba y justificaba. Por su parte, el almirante, avisado por Guajardo de las sangrientas novedades acaecidas en la sierra, y de cómo el capitán Juan Fernández de Morales dirigía las tropas de Nueva Vizcaya en la represión del alzamiento, envió a don Pedro, gobernador de los indios yécoras de Mobas, con auxiliares que reforzasen el campo español; y sabiendo luego cómo Lasso de la Vega se disponía a marchar hacia la villa de Aguilar -establecida por Guajardo en el centro de la Tarahumara-, ordenó nuevas levas de contingentes de indios de Nuris, Mobas, Onavas, Tonichi, Sahuaripa y Arivechi, que serían muy útiles para combatir a los alzaclos, y eran los más próximos al teatro de la guerra. "En cuanto yo pudiere - dice el aragonésacudiré a causa tan del servicio de Vuestra Majestad".

Sin embargo, como Guajardo le pidiese que entrase él mismo, al frente de los presidiales de Sinaloa, en la Tarahumara, Porter se negó haciendo valer sus razones: "Ayer -escribe en Io de julio de I650- 52 llegué a esta villa con la gente de estos presidios después de haber andado tres meses en campaña visitando estas provincias, habiendo marchado más de trescientas leguas con caballos armádos, con que la mulada y caballada ha nenester muchos días para rehacerse, y ya han entrado las aguas, y así no es posible liacer lo que V. S. me dice en la suya, además, señor, que para la jornada que he hecho ha sido necesario gastar para el herraje todo el hierro que tenía de fábricas y también me hallo falto de pólvora, pues desde que estoy en esta provincia, que va para cuatro años, no se me han enviado municiones ni pertrechos, habiéndolos solicitado

52 Porter a Guajardo, Sinaloa, Io julio I650. Ibid. 
constantemente... y para hacer entrada es necesaria ayuda de costa, como V. S. sabe y se acostumbra, para sustentar el campo y los indios amigos que hubiera de llevarse, pues ni la provincia pudiera visitarse si los Padres de la Compañía de Jesús no sustentaran el presidio de unos pueblos a otros, y así antecedentemente se ha de prevenir todo lo necesario y comprar los bastimentos a los Padres, que son los que pueden darlos". En último término, tampoco creía Porter prudente que los soldados salieran de la provincia en tales circunstancias para entrar a la sierra. Pocos textos más ilustrativos que el citado para conocer las características de la actividad militar en Sinaloa y Sonora en el momento: el uso de caballos armados en esta época, la falta de hierro y pólvora, la dependencia de las misiones para cualquier movimiento de tropas, etc.

En fin, Porter, cumpliendo órdenes de México, había realizado la visita de Sonora, y en cambio se negaba a cooperar en la pacificación de Tarahumara. Aún empeoró la situación el hecho de que, cuando Lasso se disponía a entrar desde la alcaldía de Sonora hacia la villa de Aguilar - debía ser a mediados de 1650 - se supo que "habían muerto alevosamente en dicha provincia de un arcabuzazo a dicho capitán Simón Lasso de la Vega”. Guajardo nombró en su lugar y para investigar aquella muerte precisamente a Juan Fernández de Morales, que partió del campo del gobernador el 5 de octubre de ${ }^{6} 6_{5}$ para dirigirse a Sonora, pero ya es sabido de qué manera impidió Porter que pasase a hacerse cargo del mando de esta provincia, "con lo que no se consiguió el socorro que se pretendía, ni se castigó el delito". 53 Porter se mantuvo en el mando de Sinaloa hasta su dimisión en 8 de noviembre de 165 I, llamado a intervenir en la defensa del Perú contra los piratas. 54

Treinta AÑOS DE PAZ

Concluida la rebelión tarahumara y relevado Porter del go-

53 Guajardo a S. M., Parral, 26 de febrero I65I, y testimonio adjunto. Ibid.

54 Relación de servicios de Porter, Lima, I 5 setiembre 1655, Portillo, ob. cit., apéndice XX, pág. 522 . 
bierno de Sinaloa, contintuaron los gobernadores de Nueva Vizcaya nombrando alcaldes mayores capitanes a guerra para la provincia de Sonora. Y entró la frontera noroeste de Nueva España en una etapa de paz y prosperidad. A decir verdad, las provincias costeras sólo habían padecido en las ocasionales inquietudes de sus propios indios; acajees, jijimes, chínipas, tepehunanes y taraht1maras bajos sólo habían significado para ellas un riesgo cierto y cercano, sí, pero nunca actualizado en forma de subversión repentina de los dominados o invasión incontenible cle los serranos. Ahora, en cambio, Sonora y Sinaloa se beneficiarían de una serie de acontecimientos derivados de manera más o menos inmediata de la última conmoción; todos ellos conducirían finalnente a liquidar el relativo aislamiento en que hasta entonces había vivido Sonora.

El primero de estos hechos - ya alıdido anteriormente- consistió en el establecimiento de misión y alcaldía mayor en Casas Grandes, mediando la distancia entre Sonora y El Paso, doncle los misioneros franciscanos de Nuevo México se habían asentado descle mitad de siglo. La ocupación de Casas Grandes debe datar de i66I, por cuanto en I666 se hacía constar que hacía más de cinco años que no se ponía alcalde mayor en estos parajes, por lo que había venido ejerciendo tal oficio el capitán Andrés López de Gracia. 55 Este acontecimiento es para Sonora tan decisivo como lo muestra el hecho de que precisamente en 9 de junio de 1666 se nombralia alcalde mayor de Casas Grandes al capitán don Francisco Alvarez de la Bandera, que en 25 de enero del mismo año había sido designado alcalde mayor de Sonora. ${ }^{6}$ Las dos jurisdicciones separadas geográficamente por la sierra aparecen así políticamente unidas, anticipando la idea del socorro mutuo en un frente común que se hará patente andando el tiempo. Dos años después, el general don Carlos Gago de Mendoza reuniría los mismos títulos que

55. En el título de Alvarez de la Bandera, Parral, 9 junio ч666. Escribanía, 397 A, pieza 21 de la residencia de Oca Sarmiento, fols. $35 \mathrm{v} \cdot-36$.

${ }_{5} 6$ Vid. nota anterior. Todos los títulos de Alvarez de la Bandera, ibid,, fols. 10-I $2,34-37 \mathrm{~V}$. 
Alvarez de la Bandera -alcalde mayor, capitán a guerra, teniente de gobernador y de capitán general, visitador, juez de residenciasobre Sonora, Casas Grandes y Ostimuri, recién nacicla esta última provincia. 57

El otrn hecho de interés entraría en lo puramente fortuito si no hubiera venido posibilitado ya por el tránsito de mercaderes y tropas habido a través de la Tarahumara en los últimos tiempos. Consiste en los sucesivos descubrimientos de yacimientos mineros ocurridos en esta zona a partir de los años sesenta, y que naturalmente habían de atraer a buena porción de españoles y gentes de razón a este territorio que hasta entonces se había conservado indio cien por cien.

San Diego de Minas Nuevas y Ostimuri - creado alcaldía en I668- no son más que el pórtico del desarrollo minero del noroeste, que va jalonado por los descubrimientos posteriores de Alamos, Cusihuiriáchic, Uríque, etc., hasta el real de Santa Eulalia, luego Chihuahua, en los umbrales del XVIII.

La paz de que disfrutaban las alcaldías costeras dio ocasión al sucesor de Guajardo, don Antonio Oca y Sarmiento, para proponer la disminución de los efectivos de Sinaloa con objeto de reforzar la frontera oriental de Nueva Vizcaya, entonces muy amenazada, y donde Oca proyectaba establecer diez atalayas que cubriesen el camino real de México a Parral. "En el presidio de Sinaloa, que es una de las provincias de este reino - escribía el gobernador-, ${ }^{8}$ tiene Vuestra Majestad cuarenta y cuatro soldados y un capitán con dos mil pesos de sueldo, y un caudillo con mil. Esta provincia es de indios muy mansos y muy quietos, adonde no hay alzamiento ni se ha conocido inquietud alguna. Puédense sacar veinte soldados de aquel presidio (que no hay razón ni pretexto para que no haciendo alli guerra ni daños el enemigo estén los soldados ociosos cuando hacia la parte que digo - se refiere a los

57 Ibid, fols. 122-1 $26 \mathrm{~V}$. Son títulos y conisiones de 5 y 6 noviembre 1668 .

58 Oca a S. M., Parral, Ig marzo 5667 , adjuntando mapa. Guadalajara, 19. Oca al virrey, Parral, I 2 marzo I667, eli Bandelier, II, I88-I9z. 
bordes del Bolsón de Mapini- están destruyendo este reino y provincias, y si aquélla padeciera las hostilidades que éstas, de aguí se había de socorrer)". Las faligas de Hurdaide y Perea en los charenta primeros años de] XVII habían dado cono fruto la consolidación de una paz tan finte como para liacer verdaderas las palabras de Oca, un ctarto de siglo después, de que los indios de Sinaloa "nunca" habian tenido inquietudes.

La única turbación que se ofrecerá por esta parte en las tres décaldas que ahora recorremos la proporcionan los seris, extraños siempre en realiclad a las provincias, conno que nunca fueron dicazmente dominados, y empujados ahora a hostilizar las misiones vecinas a su territorio por la sequía y hambre que hacia 1670 se hace sentir desde las praderas texanas a las orillas del mar de Cortés y es uno de los principales factores determinantes de la subsiguiente conmoción de to da la frontera española. Las dos victoriosas entradas y la muerte del capitán de Sinaloa Andrés de Bucha en 167 I han sido ya narradas en páginas anteriores.

Para que no quedase rota la tradicional vinculación de nuestra costa con la península vecina, en la década de los sesentas -1664, I668- tiene lugar una serie de expediciones a Californias, dirigridas esta vez por el almirante don Bermardo Bernal de Pinadero, a quien no favoreció la fortuna y hubo incluso de padecer 111 motín de sus hombres, y que tuwo primeramente su base en el Valle de Banderas, pero que acabó solicitando del rey en r67 I la concesión del gobierno y capitanía del presidio de Sinaloa para continuar sus tentativas de entrada y poblamiento de la península. 50 Tales instancias, unidas al cleseo que ciertamente había en la Corte de que dicho poblamiento se hiciese, movieron a lí Corona a otorgar facultad al virrey para capitular la conquista de California con quien se ofreciese a realizarla con sus propios medios, y si no, a costa del real erario. Así lo conseguría Atondo. Hacia 1670 se sitúan también las navegaciones californianas del capitán Francisco

59 Soliciturl de 30 diciembre i $67 \mathrm{r}$, en Guadalajara, I34. 
de Lucenilla, uno de cuyos barcos varó y ardió en la costa del Yaqui, siendo el otro un "muy razonable vaso", 60

Finalmente en I 677 ó I6.79 tuvo lugar la primera fundación de misión para los seris, que fueron congregados en bastante número por el jesuita P. Fernández en Santa María del Pópulo, paraje próximo a la junta de los ríos Sonora y San Miguel. ${ }^{6 r}$

I680, EL AÑO DEL JESASTRE. ATONDO

Hacia I680, la frontera española cobra nuevo ritmo, la documentación sobre los acontecimientos se hace más abundante, y nuestra narración gana en precisión lo que pierde en rapidez. La crisis que entonces se clesencadena para Sonora es presenciada desde Sinaloa y Californias por el alcalde mayor don Isidro de Atondo y Antillón.

Como ya se dijo, el virrey de Nueva España había recibido autorización - por reales cédulas de 26 de febrero y 18 de junio de 1678 - para admitir las proposiciones que pudieran hacérsele por particulares para acometer la ocupación de la península californiana. Publicadas tales disposiciones, el 8 de noviembre de 1678 se ofreció el capitán y ayudante general don Isidro de Atondo para llevar a cabo tal empresa. Atondo había sido ya alcalde mayor y teniente de capitán general de Sinaloa de 1673 a 1675 , de cuyos empleos había dado una "residencia" satisfactoria. Ahora pedía, para entrar en California, treinta soldados pagados por la hacienda a trescientos cincuenta pesos, y un cabo a seiscientos veinte, "y se le ha de dar facultad para que en las ocasiones que se of recieren pueda llevar de los presidios de Sinaloa los soldados que hubiere menester"; había que hacer acopio de bastimentos en esta costa, y proceder a la construcción de barcos, y "por cuanto para la asistencia de dichos bastimentos, para la fábrica de dichas fragatas

60 Declaración de Felipe Bermejo de la Carrera en Parral, I 5 marzo I68r, en lestimonio adjunto a carta de Estrada a S. M., Durango, I5 abril I68I. Gua-; dalajara, 29.

61 Decorme, II, 446. 
y para valerse de los soldados de los presidios de Sinaloa en los casos necesarios necesita de tener toda autoriclad en dicha provincia, se ha de servir V. E. de nombrarle luego por gobernador de dla en lo político y militar en conformidad de la facultad que se concede a V. M. por las nuevas reales cédulas que hablan en esta materia".

Dando su parecer al virrey sobre la materia, escribia en 1678 el fiscal don Martin de Solís Miranda: "parece precisamente necesario el que V. E. se sirva de hacerle merced del gobiemo de Sinaloa y Sonora, por lo menos por tiempo de ties años y si pareciere por cinco, despachándole asimismo título de almirante de las Californias y de los navios que llevare... conno también el que se le conceda facultad para aprovecharse de los soldados de aquellos presidios en las ocasiones que se le ofrecieren, y annque se puede ofrecer duda de concederle el título de alcalde mayor en lo político de Sinaloa y Sonora por pertenecer esta provisión al gobernador de la Nueva Vizcaya, cono quiera que a V. E. se le concede facultad por las réieridas cédulas de 26 de febrero y is de jumio para poler capitular, asentar y disponer dicha ntteva conversión, parece haberse concedido todo lo conducente a su logro y disposición, y si V. E. fuese servido podrá, sin embargo, hacer insinuación de la tal voluntad a dicho gobernador o despachar la provisión de ruego y encargo, para que despache título de alcalde mayor o gobernador de lo político de las referidas provincias al suplicante, o le consienta el uso y ejercicio en virtud del título que V. E. le despachare en conformidad de lo que se capitulare". "62 Tales palabras del fiscal explican la conducta clel virrey, aunque no la despectiva actitud que en la práctica parece adoptó sobre los derechos del gobernador de Nueva Vizcaya, dando con ello lugar a los choques de éste con Atondo.

Representó éste, por su parte, la conveniencia de que se le otorgase el gobierno político y militar de Sinaloa por cinco años,

62 Testimonio del "isiento" en Patronato, $3 \mathrm{I}$, ramo $44^{\circ}$. 
porque sólo en cortar y conducir maderas, fabricar bajeles, etc., se irían dos años, y sólo en el tercero se podría efectuar el primer viaje a la península; "y aunque el Sr. fiscal propone los gobiernos de Sinaloa y Sonora, el suplicante reconoce que no necesita de la jurisdicción política de la provincia de Sonora". Atondo decía esto con algún fundamento, puesto que ya de I673 a I675 había ejercido la alcaldía de Sinaloa. En su lugar indicamos cómo el electo gobernador de Parral, don Bartolomé de Estrada, estuvo presente a la Junta General de Hacienda celebrada en México en 28 de noviembre de 1678 , en la que aprobó el asiento propuesto por Atondo, y que fue definitivamente estipulado el i6 de diciembre siguiente.

Así pues, Atondo pudo pasar con todos los poderes a la villa de San Felipe y Santiago y dar comienzo a los trabajos del astillero de Nío, vinculando una vez más históricamente ambas costas del golfo. En Sinaloa le sorprendieron las noticias del desencadenamiento de la gran guerra de la frontera cuyo primer acto lo constituye la sublevación de los indios pueblos de Nuevo México.

La catástrofe acaecida en esta provincia fue muy pronto conocida en su retaguardia de Nueva Vizcaya y en la vecina de Sonora. Estrada preparaba un ataque a los habituales enemigos del camino real: "espero que lleguen los soldados de Sinaloa que envié orden a don Isidro de Atondo en virtud de la que tuve de Su Majestad". ${ }^{6}$ En realidad había abandonado ya tal esperanza, puesto que el comportaniento del virrey le había dejado desautorizado a él frente al almirante. Sus órdenes habían sido las de reclamar veinte hombres del presidio de Sinaloa y cinco del de San Sebastián y hacer salir al alcalde mayor de Sonora con toda la gente que pudiese en socorro de los fugitivos de Nuevo México, aislados en la zona de El Paso; en el mismo sentido había enviado

63 Estrada al virrey, Parral, 22 julio 1680 . Guadalajara, I38, fols. 3ov.-33 de los autos sobre alzamiento de Nuevo México. 
otros despachos al alcalde mayor de Casas Grandes, Andrés López cle Gracia, 64

E1 is de setienbre, por cartas del Padre Aycta que vinieron de El Paso y Carretas, se tuvo en el real de San Juan Bautista de Sonora la noticia del alzamiento de los indios pueblos cle Nuevo México, y de cómo el gobenador Otermín había logrado escapar casi milagrosamente. El ex-gobernador interino de Nueva Vizcaya, don Francisco de Agramont, reconocía el peligro que amenazaba a toda la frontera, "porque los janos y sumas y otras naciones de aquí que confinan con ésos, todos son de runos humores, y quizá peores". La indefensión de las provincias era general, a juicio de Agramont; ${ }^{65}$ el entonces sargento mayor de Sonora, Juan Bautista Escorza, parecía más optimista sobre el particular: hacía tiempo que tenía pedido a Atondo acudiese con el presidio de Sinaloa, y él se atrevería a ir de San Juan a Senecú, por Teuricachi, en siete días. 66

Atondo, atareado como estaba en su astillero, y enzarzado en polémicas con el gobernador cle Parral, tardó bastante tiempo en pasar el Canal y en socorrer la frontera.

\section{LÁZARO VERDUGO Y LA CONSPIRACIÓN ÓPATA-APACHE}

El contagio temido descle el primer momento del mal ejemplo del alzamiento de Nuevo México sobre los indios sometidos cle toda Nueva Vizcaya, tuvo su primera manifestación en Sonora un año después, en tuno de los muchos episodios hasta hoy desconocidos de la historia de la provincia, y que es al mismo tiempo parte de la serie de acontecinientos, de alcance incalculable, que se escalonan entre la pérdida y la reconquista del bastión español de Nuevo México.

64 Estrada al virrey, Parral, 7 setiembre I68o. Ibid, fols. 4 I v. $-43 \mathrm{v}$.

65 Agramont a Otermín, San Juan Eantista, i6 setiembre I680. En "Testimonio de autos tocantes al alzamiento general de los indios de la provincia de Nuevo México", núm. 1, fols, 273-275v. Guaclalajara, i 38 .

66 Escorza a Otermin, San Juan, I7 setiembre 1680. Ibid,, fols. 275v.-278v. 
Duró la alarma en Sonora poco más de un mes, iniciándose en San Juan Bautista el 2 de julio de I 68 r cuando el alcalde nuyor Lázaro Verdugo formó junta de guerra de vecinos para tomar declaración al indio Javier, ladino en Castilla, criado de Lorenzo Quintero, que declaró ante la asamblea que de tiempo atrás sabía él cómo había juntas de indios en Chinapa, donde se trataba de organizar una rebelión con la ayuda de los pueblos de Bacuachi, Cuquiarachi, Tebideguachi, Cuchuta, Teuricachi, San Juan Guachinera, San Miguel Bavispe y San María Basaraca; como a los sometidos pueblos de Nuevo México, no les faltaría a estos ópatas el auxilio de los apaches, representados en esta frontera, como Escorza había tenido, por los cristianos sumas y janos y los gentiles jocomes y otros del río arriba de Bacuachi. Verdugo creyó llegado el momento de actuar rápidamente y con mano dura. Inmediatamente ordenó a Lorenzo y Lucas Quintero acudiesen a Chinapa y Bacuachi a prender a los cabecillas. Ordena al capitán Pedro de Peralta, su teniente de alcalde mayor y capitán a guerra del real de Nuestra Señora del Rosario de Nacosari fuese con diez hombres al día siguiente, 3 de julio, a prender al gobernador, alcaldes $y$ topiles de Cuquiarachi. ${ }^{67} \mathrm{El}$ propio Verdugo salió el día 2 a las ocho de la noche del real de San Juan con diez hombres y a marchas forzadas llegó a Chinapa el 4 al salir el sol. Estas fueron las primeras gestiones de la represión ya puestas en marcha, y dieron como resultado una serie de detenciones, declaraciones y ajusticiamientos. El i I de julio estaba el alcalde mayor prosiguiendo sus pesquisas en Cuquiarachi; 68 el I4, ya concluidas sus diligencias en este lugar, despachaba comisión a Juan Bautista Escorza, que se hallaba en el valle de Tepache, jurisdicción del real de San Juan,

67 Escribania, $400 \mathrm{C}$, pieza 2. "Autos hechos contra el general don Franciseo Cuervo de Valdés. Legajo sobre los indios, Autos que se fulminaron por el general Lázaro Verdugo y don Francisco Cuervo en el tiempo que administraron justicia en la provincia de Sonora sobre la conspiración de los indios de dicha provincia, etc,". Cuaderno $80^{\circ}$ del proceso contra Cuervo, 768 fols. La junta del real de San Juall, 2 julio $168 \mathrm{I}$, en fols. $3-4$.

$6 \mathrm{~S}$ Ibic. fols. 4-4v. y 32-32v. 
para que con título de tenicnte general a gutura en toda Sonora retniese cierto número de vecinos armados y pasase a hacer indagaciones en los pueblos de la Sierra Madre, por la parte de Nacori, Escorza obedeció el 20 de julio, retunió dieciocho hombres, de los que catorce armados de arcabuz, y marchó a Bacadeguachi, donde pronto puso a buen recaudo respetable cantidad de indios complicados en la intriga, legando dos de ellos a pagar con la vida su infideliclad. 69

Entre tanto, Verdugo ya se había desplazado el ip de julio a Bavispe, desde donde incluso reclamó algmnos individuos a Andrés López de Gracia, de Carretas, y el I9 y 20 visitó Santa María Basaraca y San Juan Guachinera, y de estos pueblos del río de Bavispe bajó a Bacadegruachi, donde el 28 encontró a Escorza, cuyos actos de justicia confirmó. El 29, habiendo sido llamado Verdugo a San Juan por su sucesor Cuervo, dejó a cargo de Escorza todo el arreglo de la difícil situación por que atravesaba la provincia 70 y en este supuesto entró Escorza en Guachinera, en zo de julio. Tres días más tarde estaba allí el alcalde Cuervo Valdés para ratificar sus sentencias, y hechos los últimos castigos, se daban por concluidas las gestiones para averiguar las ramificaciones del movimiento subversivo abortado, 71

Las docenas de sospechosos examinados por Verdugo, Peralta y Escorza dieron una masá de informes que, dejando claramente establecida la realidad de la conjura, ofrecen sin enbargo nna extensa gama de variantes en punto a sus orígenes y al modo en que debería producirse. Probablemente 10 más exacto será decir que llevaba bastante tiempo gestándose en la Opatería un ambiente de inquietud que, desde hacía tres años, segín la confesión de Javier Jauri $72-y$ esto llevaría los orígenes de la conspiración a fecha anterior a la de la rebelión de Nuevo México - venía to-

\footnotetext{
69 Ibid. fols. $42 \mathrm{v} .-69$.

70 Ibid, fols. $43-49 \mathrm{v}$ y 69 r.v.

7 I Ibid. fols. $70-78$.

72 Ibid. fols. 50-52.
} 
mando cuerpo en las reuniones o tlatoles celebrados en varios pueblos, y en los que tomaban parte sus gobernadores, alcaldes y topiles. Este ambiente general es lo que hace confusas las noticias sobre los motores y la vía de penetración de la conjura. Para nosotros sería lo más fácil entender que todo ello se había iniciado después de la huida de los españoles de Nuevo México, cuando El Paso se convirtió en su refugio y en foco de agitación para todos los grupos indios vecinos. Así esta agitación había venido transmitiéndose a través de las misiones franciscanas de conchos y sumas hasta Carretas, y de aquí pasó a Sonora. Algunos de los ópatas indicados de Cuquiarachi decían efectivamente que el "convoco" había venido de Casas Grandes; otros, como Francisco Baduque e Ignacio Jojoi parecían haberse movido espontáneamente al conocer el ejemplo dado por los pueblos. Esta iniciativa de algunos jefes ópatas parece haber sido lo más decisivo.

Jojoi confesó haber ido por su voluntad a Bacobichi a tratar el asunto con Diego Suri, quien aceptó la idea con todos los indios de Bacobichi. Todos los de Cuquiarachi estaban dispuestos a seguir a Jojoi, y éste, que se aconsejaba con otro llamado Basusa - muerto tres meses antes de descubrirse la conspiración- envió al indio Banasuri a comunicar su propósito al gobernadorcillo de Bavispe, Lucas Canari, que también admitió el tlatole y dijo estar dispuesto a ponerse de acuerdo con los sumas aunque recientemente se había disgustado con ellos. Es significativo que Jojoi confesase a Verdugo que los sumas todavía no habían dado su respuesta, mientras que Baduque, que se decía inspirador de los movimientos de Jojoi, declaraba saber que los sumas de Carretas estaban dispuestos a colaborar en la rebelión. En cambio, Jojoi decía contar con la cooperación de los indios de Guachinera, Chinapa y los gentiles de Quiburi -que eran sobaipuris. Uno de los declarantes pretendia que incluso los pimas de Cucurpe y los seris habian sido avisados de lo que se tramaba. El movimiento debería estallar en el invierno próximo, en octubre según Jojoi; el delator y Lázaro Verdugo se habían adelantado más de dos 
meses. El plan del levantaniento era muy simple: un grupo de los complicados atraería a los españoles con una falsa alarma y los sorprendería mientras los demás asaltaban los ptreblos so capa de apaches. 73

En Chinapa, que fue por donde se descubrió la trama, las declaraciones coincidian en señalar que el tlatole vino de Cuquiarachi, a través de Diego Suri e Ignacio 'Turuque, gobernador este último de Bacuachi. Sin embargo, el propio Turuque aseguraba que el convoco vino de los sumas y janos a Cuquiarachi: tal vez Jojoi y Suri lo habían dicho así para aparentar más fuerza de la que realmente tenían. De Bacuachi el tlatole había pasado a Chinapa y al valle de Sonora, donde fue rechazado, y además se emprendieron nuevas gestiones para asegurarse el refuerzo de los gentiles. Pablo Mara, en cuya casa de Chinapa tenían lugar las reuniones que delató Javier, había entrado a la gentilidad descle la Cananea hasta Quiburi y hasta el río Grande y Terrenate y Guebavi, hallando que estos indios no se atreverían a luchar en llano, sino en sierra, con los españoles - -señal segura de que no tenían caballos. Por su parte, Turupue aseguraba que Diego Suri, desde Bacuachi, había entrado hasta la gentilidad más remota, buscando aliados para consumir a los españoles en los próximos fríos, pero los necuas gentiles tampoco aceptaron la idea, "porque se quieren estar quietos y pacíficos, sembrando, y que tienen que comer con eso, y que no son apaches, ni sumas para andar huyendo ni comiendo mezcal, sino estarse quietos". Uno de los principales sospechosos de Bacuachi, Francisco Quigue, joven guerrero de veinte años, contó cómo Suri los había empujado a él, al gobernador Turuque y a Juan Caiso, sacristán, a entrar a los apaches para atraérselos y matar a los Padres que los azotaban, al capitán que los ahorcaba, a los españoles para quitarles los caballos y las vacas, y a los mercaderes para apoderarse de las camisas, calzones y ropas. Al parecer ya habían hecho acopio de flechas, que tenían ocultas en la sierra,

73 Declaraciones en fols, 24-37. 
para cuando llegasen los fríos. El contacto con los apaches no debía ser difícil, porque éstos entraban por la noche hasta las proximidades del real de San Juan, caminando por la sierra entre Cumpas y Nacosari: tal dato proporciona clarísima idea de la permeabilidad de la frontera española en Sonora. 74

Chinapa, Bacuachi, Cuquiarachi y Teuricachi eran pueblos evidentemente comprometidos en la conspiración. El tlatole le había llegado hasta Arizpe, como que lo llevó Javier Jauri a los pajes del misionero, uno de los cuales, Lorenzo el Boquinete, decía que los españoles eran lentos en cargar los arcabuces y entretanto ellos les darían cuatro jarazos. Pero Arizpe no debió sumarse a aquella intentona; tampoco Guazavas, pues los conjurados de Bacuachi hubieron de dar muerte a un indio de este pueblo que quiso delatarlos. 75 En cambio, cada vez parecía más seguro que Cuquiarachi había llevado la dirección del alzamiento que se preparaba.

Las diligencias de Verdugo y Escorza en los pueblos orientales dejaron al menos esta impresión, toda vez que Verdugo y sus consejeros de la junta de guerra celebrada en Bavispe el i 8 de julio resolvieron no forzar mediante tormento a declarar al gobernador de este pueblo Lucas Canari, contra quien pesaban las graves delaciones de Jojoi, en atención a que Canari tenía título de capitán a guerra de la frontera de Santa María Basaraca y San Juan Guachinera además del gobierno de Bavispe, y su persona era muy útil para la defensa contra sumas y janos. ${ }^{6}$ Así pues, en Bavispe sólo se tomó confesión al fiscal mayor Pablo Quigue, por medio del suma Baromi y de otro indio de Bavispe llamado Matequi. 77

Por Bacadeguachi corrían vientos de inquietud, debido quizá al gran número de sellos que se despachaban. El mestizo José Ramos declaraba en Tepache haber advertido movimiento de indios de diferentes naciones, entre ellos un jova, que suponían iban a

74 Ibid, fols. 9-I $2 \mathrm{v}$.

75 Declaración de Javier Jauri, fols. 50-52.

76 Junta de guerra, en fols. $47 \mathrm{v} .-48$.

77 Ibid. fols. 43-44. 
agitar los pueblos. $7^{8}$ A Bacadeguachi habían llegado tlatoles de Bavispe, hacía muño, y también mensajeros de otros pueblos más al norte que habían dicho que nás allá en su país tno que llamaban el Buchanrini había proclanado que toda la tierra la tenían echada a percler las vacas y bestias, que por eso la tierra no daba ya frutos como antes y se secaban los aguajes - alusión sin ducla a las hambres y sequías de los setentas; que él era dios, que había hecho todo, y no quería que vendiesen maíz a los españoles y que fuesen cristianos, que más valía que quemaran a todos los españoles y vivirían más a gusto, y habría agua en la tierra; lo mismo decía otro llamado Batacuma. Por aquí se decía que el centro de la rebelión estaba en Guachinera, 79 pero los indios de este pueblo, a clonde acudian muchos conchos gentiles y cristianos, aunque estaban seriamente complicados en la conspiración, entendían que los de Chinapa y Bacuachi los capitanearían a todos. Las indagaciones de Escorza en Guachinera le llevaron a la decisión de enviar el 2 de agosto seis soldados a Bavispe para que trajeran preso al Canari; so que esta vez no se salvó, porque el 3 llegaba el nuevo alcalde mayor, Cuervo, a reunirse con Escorza, clispuesto a concluir con cualduier recelo de sublevación.

\section{Paz y Redeldía con Francisco Cuervo de Valdés}

E1 3 I de julio había teniclo noticia Cuervo en San Juan de Sonora de la actividad de Escorza en Gnachinera y de la indicación de ésta para que se apresase a los gobemadores de este pueblo y el de Basaraca que venían precisamente a dar sur obediencia al nuevo justicia. Cuervo hizo aprestar diez hombres, ${ }^{8}$ arrestó por el camino a la embajada que venía a su encuentro, y una vez en Guachinera les tomó declaración a ellos y a Lucas Canari. E1 6, después de recibido un pedimento del misionero P. Estrella a favor

78 Declaración de Ramos ante Escorza, en fols. 55.

79 Ibid. fols. $56 r,-63$.

So Ibjid. fols. 70-77v.

Si Auto de Cuervo ell el real de San Juan, 3 I julio I68r. Ibid. fol. 248. 
de los culpados, "que como fáciles y desdichados han caído en semejante culpa y delito", prontunció sentencia. ${ }^{82}$

Verdugo había condenado a la pena capital a Jojoi y Baduque en Cuquiarachi, el I4 de julio; y a Mara, Jura y Turtuqe, en Chinapa, seis días antes. Escorza sentenció a muerte a Maiboca y Duqui en Bacadeguachi, el 24 de julio. Otros varios convictos habían sido condenados a azotes, a pasar bajo la horca, o a trabajos forzados. Escorza había hecho quemar todas las armas de Bacadeguachi, y prohibió a los del pueblo usar arco y flechas durante un año. Ahora Cuervo pronunció la última pena para los tres gobernadores Juan Uro de Guachinera, Bagueri de Basaraca y Lucas Canari de Bavispe y para otros seis ópatas, de los que uno fue luego indultado. Las ejecuciones tendrían lugar en los pueblos de los condenados, pero el Canari fue arcabuceado en Basaracia porque la crecida del río no permitía que se le condujese a Bavispe. ${ }^{8}$

Después de estos escarmientos, la paz parecía asegurada, pero no tardó en verse cuán frágilnuente había sido establecida. El 8 de octubre declaraba Lorenzo Quintero ante el teniente de alcalde de Nacatabori, Pedro Valencia, en el valle de Tepache, haber observado claros síntomas de que los indios querían alzarse, enojados porque las vacas del propio Quintero se habian comido una milpa de calabazas y sandías de ellos. Se reunían a chupar - esto es, a fumar- en la junta de los ríos, y allí hacían planes para una nueva intentona. Valencia procedió a prender al topil Juan Juraque, quien dijo haberle venido el tlatole de Guazavas, y confesó poseer flechas enyerbadas y dos canutos de veneno. Cuatro días más tarde, Salvador Moreno, José de Valencia y el gobernador de Tepache denunciaban ante el mismo teniente a Jerónimo Jumari, que hacía un mes venía dando tlatoles para vengar a los ajusticiados. Se le detuvo en la hacienda de sacar plata por fuego del difunto capitán Andrés de Almagro en el real de San Juan Bautista, y confesó

82 Ibid. fols, $248 \mathrm{v},-265 \mathrm{v}$,

$8_{3}$ Ibid. fols. $266 \mathrm{v},-268 \mathrm{v}$. 
tener el propósito de convocar a los ópatas y a los gentiles, hasta los apaches, contra los españoles. ${ }^{84}$

Así hubo de recomendarse la búsqueda de los complicados, que llevó a Cuervo, que estaba en Nacosari, a ordenar otras detenciones en Teuricachi y Cuquiarachi, donde fueron presos Francisco Banasuri y Manuel Tasina. A favor de éste, protestando haber sido detenido en sagrado, reclamó el P. Antonio Leal, amenazando con excomunión a Cuervo, que hubo de ceder, aunque pensaba que el misionero no tenía razón. ${ }^{85}$ Banasuri, en cambio, confesó que desde hacía cuatro meses había dado tlatoles en varios pueblos; que los sumas y jocomes estaban nuevamente de acuerdo y que había muchos ópatas deseosos de vengar a sus parientes. Según Banasuri había flechas escondidas en la cueva de Tosocomoche, a diez leguas de Cuquiarachi, y la rebelión estaba prevista para la luna llena de aquel mismo mes de octubre, y comenzaría con el asalto de las cuatro casas de españoles que había en el valle de Teuricachi, para convertirse, con auxilio de los de Cuquiarachi y los stumas y jocomes en un ataque contra Nacosari y el real de San Juan. Otros presos dijeron que el tlatole había venido de ios sumas, por Carretas, cuyo gobernador había recibido visita de diez apaches y habían conversado sobre los sucesos de Nuevo México; los jocomes y los gentiles de Napo también habían enviado embajadas y Tamichopa, Bavispe, Bacobichi, Chinapa y Arizpe estaban comprometidos en el levantamiento. ${ }^{86}$

Hasta aquí las investigaciones, cuando el 20 de octubre supo Francisco Cuervo que Cuchuta, Cuquiarachi y Tebideguachi estaban despoblados porque sus habitantes se habían ido a las sierras. Comprendiendo que el temor había sido la causa de esta novedad, Cuervo decidió en junta de guerra con sus treinta soldados enviar a los dos prisioneros menos culpados para que fuesen a buscar a los alzados con el mensaje de que si volvían en el plazo de seis días

84 Ibid. fols. $230-236$.

85 Ibid. fols. 204-205.

86 Ibid. fols. $205 \mathrm{~V} .-218$. 
10 se les castigaría por aquella fuga. Cuervo dio tal comisión, en presencia de los indios de Tenricachi, a Juan Tebacasame y Lorenzo Manche, capitán a guerra y topil de Cuchuta, a quienes como señal de paz colgó al cuello una cruz de Caravaca y un listón. \$r En Nacosari y en San Juan Bautista se comenzaron novenas y rogativas a la virgen del Rosario para alejar el jeligro del levantamiento, al tiempo que se pedia a Atondo enviase nna escuadra del presidio. 88 El recuerdo de la catástrofe de Nuevo México desvelaba a los vecinos.

El 24 de octulbre se presentaron los clos emisarios, y con ello, venían unos setecientos cincuenta indios de los tres pueblos abandonados y Tenricachi, y algunas gentes de las rancherías de la frontera. La paz se había salvado. Cuervo reconvino a aquella gente por este segundo conato de rebeldía y les amenazó con hacerles guerra a sangre y fuego caso que reincidiesen. Les comminó que no recibiesen tlatoleros, que acudiesen a sus pueblos, obedeciesen a los Padres, y a los justicias y cuidasen sus sementeras. Todos aceptaron la paz y dieron su palabra de no quebrantarla jamás, en prtteba de la cual los gobernadorcillos entregaron cada uno una cruz. Cuervo, a stu vez, en prueba de benevolencia, dio libertad a todos los sospechosos de sublevación que había hecho prisioneros. 89

Al día siguiente, con ánimo de dejar bien sentada esta concordia, Cuervo despachó al sargento mayor José Romo de Vivar con reinticinco soldados con la comisión de visitar la frontera y pueblos de Bacobichi, Chinapa y Arizpe, dar tlatoles a sus habitantes y a los jefes de las rancherías gentiles vecinas y afirmar así la amistad con los españoles. El 29, llegado Cuervo al real de San Juan, clio también libertad a Juraque y Tumari, oo José Romo cumplió su cometido. El 26 habló a los ópatas de Cuchuta; el 27, a los

S7 Junta de suerra en Teuricachi, 20 octubre I68r. Ibid., fols, 219-220v.

SS Ibid. fols. 222-226,

So Ibicl, fols. $226 \mathrm{v},-220$.

go Ibid, fols, 220 y $243 \mathrm{v},-244$. 
de Santa Rosa Tebideguachi, y envió a llanar a los sumas, jocomes y necuas fronterizos, los cuales acudieron puntualmente a dar la obediencia, "y en señal de paz trajeron sus varas de justicias los que lo eran, y en presencia de todos los soldados les di un tlatole por mano de Juan Pérez Lora, intérprete, que lo entendieron muy bien por ser ladinos en la lengua ópata los más de ellos, y después de haberse enterado con lo que les dije prometieron estar quietos y pacíficos en la amistad, y ser amigos verdaderos de los españoles, $y$ estar muy obedientes a los mandatos de la real justicia, y que de ahora para siempre estarán quietos y pacíficos; y la nación suma me pidió les hiciese un gobernador por habérseles muerto el que tenían, $y$ atendiendo a ser necesario, les nombré por gobernador a Pasachi, en nombre de Su Majestad, y les di a entender la obligación que tenía un gobernador, que viviera quieto y pacífico, lo cual prometió hacer así, y que estará muy obediente a los mandatos de la real justicia él (y) toda su gente", 9 I

Cumplida esta parte esencial de su visita - cuyos autos nos permiten dejar perfectamente situados a los atapascos gentiles vecinos de Sonora, y asistir al nombramiento de un gobernador suma por los españoles-, el 28 se encaminó Romo de Vivar a Cuquiarachi, que se consideraba centro de la última conjuración como de la anterior, y repitió allí sus exhortaciones para la paz. El 29 se dirigió en busca de la cueva de Tosocomoche, donde se decía tenían depósito de flechas los indios; la cueva estaba en un cerro altísimo y no hallaron en ella cosa alguna, ni rastro de que nadie hubiese estado en ella en muchísimo tiempo. Este mismo día a las tres de la tarde llegó a Bacobichi, donde aseguró el perdón a Juan Caizo y Francisco Quigue, sospechosos en la anterior conjura y que ahora se habian refugiado en la iglesia. $9^{2}$ Con esto, por fin, la paz de Sonora volvía a quedar consolidada, con sólo haber usado de compasión, y los ópatas no volverían nunca a apartarse de la fidelidad a los españoles.

gi Autos de José Romo de Vivar. Ibid,, fols. 245-246,

92 Ibicl. fols. 246-247. 
LA ALARMA DE $\mathbf{I} 684$.

Don Francisco Cuervo entró a gobernar Sonora en un momento crítico, y abandonó también el mando en circunstancias difíciles para la provincia, no obstante sus buenos servicios por la paz, como que hemos de considerarle artífice de la alianza ópata. Pero el año 1684 repercutió en las inmediaciones de Sonora la conmoción general de las fronteras de Nueva Vizcaya preparada por la conjuración general de janos, jocomes, sumas, mansos, chinarras y conchos, y que estalló el 6 de mayo de 1684 cuando los sumas y janos de la misión de la Soledad dieron muerte a fray Manuel Beltrán, el capitán Antonio de Albizu y a un criado coyote, llevándose cautivos seis mujeres y dos o tres niños. 93 Las misiones franciscanas de Sonora a El Paso habían de soportar en este frente el empuje de los sublevados. El capitán Francisco Ramírez de Salazar, alcalde mayor de Casas Grandes, no pudo dar la alarma y pedir auxilio a El Paso y Parral hasta el II de mayo.

En Sonora no se supo la novedad hasta el ro, cuando fray Antonio de Aguilar escribió a Cuervo desde Basaraca nartando cómo el 9 al amanecer se habían alzado los sumas de su misión de Carretas llevándose las bestias y aun las ropas de la cama, pero respetando su vida. Unos españoles que pasaron más tarde lo recogieron y trajeron a Basaraca, donde fue recibido por el jesuita P. Juan Antonio Estrella. En Carretas habían quedado los santos, imágenes y joyas del culto; el P. Aguilar daba por seguro que la rebelión se extendería desde su misión hasta Parral. 94 Efectivamente, el I 3 se fugaron los sumas de Casas Grandes, en cuyo valle no habían quedado con el alcalde mayor más que ocho hombres - cifra que permite suponer que no fueron las vejaciones de los españoles lo que empujó a los indios a la rebeldía. Así lo avisaba Ramírez de Salazar a Cuervo el día siguiente, ${ }^{95}$ pidiendo auxilios

93 José Cortés al P. Estrella. Ibid., fols. 85.

94 Ibid. fols. 79-80.

95 Ibid. fols, IOI-IO2. 
y reduciendo a cuatro el número de las mujeres robadas por los indios en la Soledad de Janos. Iz1 mismo I4 sabía el misionero de Guazaras, P. Antonio Leal, por el P. Estrella, que los sublevados habían visitado Carretas, incendiando la abandonada misión, profanando el templo y destruyendo las inágenes. 96

Entre el I 3 y el I 5 de mayo llegaron estas cartas al real de San Tuan. Cuervo, expeditivo siempre, el mismo día I3 ordenó al capitún de la milicia provincial, Juan Fernández de la Fuente -nombre que se haría ilustre a partir de este momento, como el del alcalde mayor de Casas Grandes-, que desde Nacosari, denclc se hallaba, acudiese con gente de guerra a Carretas y demás partes donde conviniese para inquirir los hechos y castigar y pacificar a los indios. Al nismo tiempo, el futuro gobernador de Nuevo León, de Coahuila y de Nuevo México, disponía la publicación de un bando para que todos los vecinos de Sonora pasasen muestra con sus armas ante los justicias de los partidos. 97

E1 I 3 publicó el bando en San Juan. El i 5 pasaban revista treinta y seis hombres en este real; el 16 se contaban doce en el valle de Tenricachi y cuarenta y dos en Nacosari; el I7, Gregorio de Año concentraba veintinneve en el valle de Tepache; Nacatobori era de los reales peor defendidos, puesto que sólo tenía once honbres armados el 2 I de mayo; el 22, Bacanuche reunía sesenta y dos milicianos; el 23, en el real de San Miguel contaba Juan de Encinas treinta y seis hombres. 98

No podría imaginarse tropa más irregtular. Los hombres que jasaban muestra no eran soldados - aunque a veces empleemos este témino para aloreviar-, sino vecinos comerciantes, mineros que se presentaban con arnıs de todas clases. Todavía en i684 había en Sonora una docena de pobladores dispuestos a usar caballos armados o acorazados. El arma de fuego ordinaria es, por supuesto, el arcabuz. De muchos vecinos se dice que se presentan armados

96 Ibid. fol. 84 .

97 Ibid. fol, $8 \mathrm{I}$.

ig Ihid. fols. 82-83,88-90v., 93-95V., I 08 , II $4-$ II 6 y I $42-$ I 43 . 
de todas armas. En Nacosari, con objeto de que todos los hombres estuviesen listos caso de ser llamados a intervenir, el teniente Pascual Volado prohibió que las escopetas pudiesen ser empeñadas por nadie. Pistolas, espadas y dagas, y alguna lanza aislada aparecen en las muestras; cueras, coletos de ante, ternos de armas, adargas y chimales se anotan profusamente en las listas.

La muestra celebrada a son de caja de guerra o de tañido de campana significaba sólo una alerta y recuento de la gente disponible. Los acontecimientos serían los que decidiesen si habría necesidad de sacar aquellos hombres a campaña. De todas partes se podía asegurar que los ópatas estaban tranquilos: esta amenaza en la frontera fue la mejor prueba de la confianza con que podía contarse con esta nación y constituyó un éxito indudable, en este sentido, para Cuervo. De Cuchuta se sabía que cuatro sumas gentiles que habían estado rancheados junto a Tebideguachi se habían huido; los ópatas que salieron en su seguimiento encontraron a un jano y a un jocome que llevaban una docena de caballos robados, y pronto se supo que janos, jocomes, sumas y otros rapados (que serían mansos o apaches) estaban formando un campo atrincherado, fortificándose de fajina y subiendo agua a un aljibe en un cerro a dos leguas de Tebideguachi. En cambio, los necuas habían avisado que persistían en su decisión de amigos de los españoles, aunque entre ellos había dos o tres individuos jocomes. 99 Más adelante, las noticias variaron en el sentido de que el campo fortificado de los apóstatas se hallaba a veinte o veinticuatro leguas de Cuchuta, en la sierra de Panicagui o Cuchicague - seguramente Chiricahui. ${ }^{\text {roo }}$

En Bacanuchi, García de Terán había formado causa al indio llamado El Canito, acusado por los gobernadores gentiles de Mototicachi, La Cananea, Santa María y Cuitacari de haber convocado a los indios del valle de Quiburi para la luna llena, pagándoles

99 Ibid. fols. 96-97.

I00 Ibid, fols. Iro-III y I27-130. 
st servicio en yeguas y cahallos. ${ }^{10}$ r Con estas alarmas, pero sin sufrir desgracias, pasó a Sonora lo que restaba de mayo.

FERNÁNDEZ Y CUERVO CONTRA LOS SUMAS

Entretanto, Juan Fernández de la Fuente se había puesto en camino hacia lit frontera de Carretas, al frente de diecinneve hombres, casi todos a pie y sin bastimentos, habiendo salido de Nacosari el I 7 de mayo a las dos de la tarde. ${ }^{\text {Ior }}$ E1 20 estaba en Guachinera y pedía a Cuervo caballos y dos o tres termos de ammas. Cuervo se las proporcionó de la caballada de Salvador Moreno, en número de cincuenta, y además nombró al gobernadorcillo de Guazavas, Francisco Javier Cuervo, capitán general de la cordillera de Guazavas, Oputo, Nacori, Guachinera, Basaraca y Bavispe, encargándole pusiera cincuenta anxiliares a disposición de Juan Fernández de la Finente, y ordenando no se sacasen indios de sello de estos pueblos. ${ }^{\text {ro3 }}$

En Basaraca supo el capitán de la milicia cómo Fr. Antonio Agurilar había persuadido al P. Estrella para que los indios de este pueblo y de Bavispe entrasen a reconocer Carretas. Esta entrada se hizo efectivamente y los ópatas hallaron la iglesia y casa del misionero ardiendo y las imágenes rasgadas, con cuyos pedazos habían hecho costales los sublevados, y de una pintura de Nuestra Señora de la Asunción no quedó sino una mano y algunas figuras de ángeles, y con estas reliquias, "y por animar a los españoles e indios amigos - dice Fernández de la Fuente-- hizo mi alférez una bandera, la cual llevamos con toda veneración en nuestra compañía, para que por su divina intercesión tengamos buen suceso". Desde Basaraca despachó dos hombres y dos indios, con un pliego, a Ramírez de Salazar, que todavía ignoraba las muertes ocurridas en la Soledad dieciocho días antes; y entonces envió seis

I I I Ihid. fols, I I9-I 23.

IOz Ibid. fols. 8S-90V.

I03 Ibid. fols. 99-I00. 
hombres a enterrar los cuerpos, que ya no se conocían. El capitán de Sonora se abstuvo por el momento de entrar a Carretas por no ser de su jurisdicción y por falta de bastimentos, pero había reunido ya bajo su mando a treinta españoles y cincuenta o sesenta indios, recibidos ya los refuerzos dispuestos por Cuervo. El alcalde mayor de Casas Grandes, en fin, le había of recido maíz, carne y caballos y le había citado para el 3 de junio para proceder a recorrer toda la frontera de Casas Grandes. ${ }^{104} \mathrm{El} 27$ de mayo había hecho Fernández muestra o alarde de su campo en Bavispe, obteniendo un total de veintisiete españoles con arcabuz, adarga y caballo, "y otras armas cortas de fuego, espadas y alfanjes que en campaña y en la guerra es permitido y usado, con pólvora, balas y cueras". El gobernador y capitán general de los indios Francisco Javier capitaneaba setenta y seis ópatas. ${ }^{105}$ Al día siguiente pasaría Fernández la sierra con toda la gente.

Tenía ya, pues, noticia de este propósito Cuervo cuando el 7 de junio recibió una carta despachada desde Basaraca dos días antes por el P. Antonio Estrella, y en cuyo sobreescrito se anunciaba ya esta novedad: "Hállase apretado el campo español". El texto de dicha carta explicaba cómo por tres indios había sabido el Padre que los españoles estaban cercados y que había muerto Francisco de Acuña, a cuya mujer hacían bailar los enemigos a la vista de los castellanos, y que también habían perecido varios auxiliares en un encuentro. Que los sitiados carecían de agua y les habían quitado la caballada, y estaban río abajo de Janos en una sierra peñascosa. Que el capitán Ramírez salió con cuarenta hombres. ${ }^{\text {I }} 6$

Inmediatamente reunió Cuervo junta de guerra, a la que asistieron los generales Hoyo Santayana y Luis de Morales, que habian sido alcaldes de Sonora, con otros muchos capitanes y vecinos, y allí se acordó que saliese a campaña el propio Cuervo con veinte

I04 Fernández de la Fuente a Cuervo, Bavispe, 27 mayo I684. Ibid., fols. I3I-I 32.

I05 Ibid. fols. I5I-I 53 .

I06 Ibid. fol. I 34 . 
españoles y por lo menos cien inclios, picliéndose a los Padres en préstanno todas las cabalgaduras que hiciesen falta; además se pedía al P. Visitador de las misiones que requiriese al almirante Atondo que enviase al candillo del presidio con veinte hombres a recorrer la frontera. Iil real de San Miguel, por su parte, delería aportar otros veinte. ${ }^{107}$ En ejecución de estos acuerdos, el 9 de junio partía Cuervo de San Juan en socorro de Fennández, dejando como teniente de alcalde mayor y capitán general a guerra del real y superintendente de todo lo militar de la provincia a don Pedro García de Almazán. ${ }^{108}$

Veamos lo que realmente había ocurrido en el teatro de lat guerra. El diario de Fernández de la Fuente ${ }^{100}$ muestra que habiéndose puesto en marcha deste Bavispe el 28 de mayo, aquel mismo día llegó a la abrasada Carretas, y el 30 se hallaba en el puesto de La Soledad, donde encontró el templo profanado. La plaza de armas y lugar designado para la conjunción con la fuerza de Casas Grandes estaba dos leguas distante, y el encuentro con Ramírez tuvo lugar el 3 de junio en el puesto de Conversión; aquí proveyó auto Ramírez otorgando a Fernández en esta jurisclicción las mismas facultades que se le comisionaron en Sonora por Cuervo. E1 2 de jurio, estando ya en el puesto del Ojo del Perro, salió todo el campo de Casas Grandes, más el tercio de Nuevo México que había traido el maestre de campo Alonso García y que se componía de doce hombres, más los veintiocho milicianos de Sonora con Fernández, a combatir a los alzados, cuyo campamento de dos mil indios se encontraba a cuatro leguas, en la sierra y peñol del Diablo. El encuentro duró seis horas, perdiendo los españoles un soldado y nueve auxiliares, y por último, con los caballos heridos y cansados y sin agua se acordó retirarse y no volver en busca del adversario, y dividir los campos para que cada nno regresase al punto de su

107 Ibicl. fols. I $35-136 \mathrm{~V}$.

I 08 Ibid. fol, I 39 .

Iog Ibid, fols. I53-I 54 . 
procedencia. La cosa no había sido, pues, tan dramática como la pintó el P. Estrella.

En efecto, el 7 estaba Fernández en Basaraca y el Io se encontraba en Oposura con Cuervo, que iba en su busca. El alcalde mayor empezó en seguida a despedir a los indios que iban a incorporársele para tomar parte en la campaña que ya no se verificaría, y los fue devolviendo a sus pueblos en esta época de las sementeras. En Guazavas el i2 de junio dio gracias por el refuerzo que prestaron a Fernández, y entregó limosnas a las viudas y huérfanos de los que cayeron en el Peñol del Diablo, relevándolos de sellos para lo sucesivo; el I5 repitió estas ceremonias en Guachinera, y el i7 alcanzó Basaraca. Aquí vino a verle Picondo, destinado por Fernández con nueve hombres a guarnecer Bavispe, pueblo que vivía con gran temor porque los enemigos jocomes conocían toda su tierra. Cuervo elevó esta guarnición y especie de presidio a doce hombres, mandados por Juan Vaca, la mitad de los cuales debían correr diariamente aquella frontera. El mismo iz emprendió Cuervo el regreso a la capital de la provincia, ino donde García de Almazán había hecho otra muestra previendo, por noticias de Fernández, una invasión de los alzados y el abandono de las misiones por los jesuitas. ${ }^{11}$

Tales presagios no eran muy extremados, como se vio inmediatamente, porque el $P$. Leal anunciaba la fuga y alzamiento de los conchos de Basaraca y de los sumas de Teuricachi, y pronto se notaron sus depredaciones en la frontera del río de Bavispe inmediata a la Sierra Madre. El P. Leal, como rector de la misión de los Mártires del Japón, pedía a Cuervo urgente socorro, considerando la situación verdaderamente grave por que pasaba aquella frontera. ${ }^{112}$ Desde Casas Grandes, Ramírez de Salazar II3 repetía las mismas demandas, diciendo necesitar especialmente tropas de

I 10 Ibid. fols. I $55^{-1} 59 \mathrm{v}$.

II I Ibid. fols, I39-I 4 IV.

I 2 Ibid. fols. I 60 y I64-165.

I1 3 I.bid. fol. I62. 
auxiliares pimas o yaquis o cualesquiera otros indios, que era lo que faltaba en su jurisdicción.

Cuervo reunió junta en San Juan el 29 de junio exhortando a todos a concurrir a la defensa de la provincia, porque como el rey no tenía en ella tropas ni efectos para levantarlas, sólo de los vecinos pendía la conservación del país. Todos replicaron hallarse prestos pese a su polreza a acudir con las armas a asegurar la frontera de Guachinera a Bavispe, que era el flanco que había quedado descubierto de resultas de la sublevación de los sumas, y así se enviaron diez hombres más de Nacosari al capitán Cristóbal Baca. ${ }^{114} \mathrm{El} 28$ las cuadrillas de enenigos habían cortado los caminos entre Guachinera y San Juan y el P. Estrella escribía: "La tierra se pierde y yo con ella y todos sus cristianos". Entre los alzados, los conchos adoptaban una actitud equívoca, viniendo algunos a establecerse más al interior de la provincia diciendo temer a los rebeldes, pero teniéndose sospechas de su comportamiento. Los campos de los tres pueblos del nordeste habían sido talados y robados; y los agresores rehusaban combatir con los ópatas, diciendo que sólo querían destruir a los españoles. En realidad buscaban atraer y asustar a un tiempo a estos indios. ${ }^{15}$

Poco después se vio que Cuervo estaba dispuesto a entrar seriamente en campaña, ordenando a Fernández de la Fuente sacar gente de los distintos reales para formar un buen cuerpo de milicianos; "y por cuanto en esta provincia no tiene Su Majestad gente de guerra pagada, ni medios para levantarla, y pedir el caso eficaz remedio, usando de la facultad que en otras ocasiones de menos consecuencia han dado los Sres. gobernadores y capitanes generales de estos reinos a sus tenientes, se despachen autos que se pregonen en todas las partes de esta provincia para que todos los delincuentes que no tuvieren delitos de los prohibidos que se presentaren ante mí para servir en esta guerra el tiempo que se les señalare queden indultados, y asimismo los mulatos, negros, mestizos y otro género

I 14 Ibid. fols. $165-167 \mathrm{~V}$.

I 5 Ibid. fols. $175-173$. 
de gentes a quien está prohibido traer armas, que sirviendo una campaña puedan usar de ellas perpetuamente. Por su parte, el teniente de San Miguel reclutaría en su jurisdicción doscientos yaquis, a los que se pagaría su trabajo y daría buen trato. ${ }^{\text {I }} 6$ E1 8 de julio se daba en San Juan como seguro que había quedado cortado el camino a Parral por Carretas, y que estaban totalmente aislados Bavispe, Basaraca y Guachinera, y que los enemigos estaban ya en el camino de Nacosari y de San Juan, en el puesto de Guepari, y atacando Bacadeguachi y Sahuaripa, "para atajar el último camino que va a salir a la provincia de Tarahumara para el Parra!". Grupos de alzados acampaban en Tamichopa. ${ }^{\text {xi }}$

Cuervo estaba tan deseoso de salir a campaña como los vecinos. El mismo I8 de junio cuando había llegado a Guachinera, había escrito a Ramírez de Salazar prometiéndole retinirse con él al frente de cinctrenta hombres y cuatrocientos yaquis, seris y ópatas; en aquella ocasión habia pedido al alcalde de Casas Grandes que le proporcionase una cuera, y éste replicaba: "haré diligencias de la cuera en El Paso, cueste lo que costare, para Vmd., o si hallase gamuzas para hacerla, que acá no las hay sino cual o cual, y esas dicen los dueños más aínas darán el pellejo que la cuera”. 118

La segunda mitad de julio se fue en reclutar la gente necesaria, mientras los Padres aprontaban cargar de bizcocho, harina y maíz y ofrecian toda la carne que fuese necesaria. El pueblo o ranchería de Teras fue asaltado por los rebeldes. ${ }^{119}$ Por fin, el 3 de agosto hizo Cuervo tocar el clarín en el real de San Juan y salió con dirección a Basaraca, incorporando en el camino indios ópatas y pidiendo caballos a los misioneros y algunos hacenderos - Salvador Moreno, Sebastián Valero, Ignacio de Sepúlveda. El r 2 estaba en Basaraca y el I 4 pasaba muestra a toda la fuerza concentrada: ochenta y siete soldados y ciento treinta y ocho indios

I 6 Ibid. fols. I73-I 74 .

i 7 Los diputados de la provincia y real de San Juan a Cuervo. Ibid., fols. 179180 .

I 8 Ibid. fols. I8I-I82.

1 I 9 Ibid. fols. I82v.-I87. 
de Guzavas, Batuco, Cumpas, Oposura, Nacori, Bacadeguachi, Serva, Pinas, Basaraca, Guachinera, Bavispe, Arizpe y Chinapa. Entre los milicianos sólo se señalan clos mulatos; ignoramos el numero de delincuentes que se alistaron buscando la redención de su culpa. I 20

El I 5 de agosto, dividida toda la fuera en cuatro compañías mandadas por Pedro García de Alnazán, Francisco Pacheco, Andrés de Rezábal y Cristóbal de I.eón, dejando sólo nueve hombres para escolta de Bavispe y Basaraca, Cuervo hizo tocar marcha y el campo se movió hacia Carretas. El I 7 estaba en Carretas, el Ig en Ojitos Fríos, y dos días después efectuaba la conjunción con Ramírez de Salazar, decicliéndose aculir al Peñol del Diablo, y luego al paraje del Alamo Hueco, pero ni aquí ni en la vecina sierra se halló a los enenigos. En el Peñol pudo Cuervo recoger los cuerpos de los que allí murieron hacía dos meses, para que fuesen enterrados en sagrado, y vio la fortaleza del cerro y las defensas que hicieron los alzados.

La campaña empezaba a clar frutos negativos. Por parte alguna se hallaba al enemigo. Pero no era poco que Cuervo hubiese marchado con paz absoluta y camino expedito descle San Juan al Peñol del Diablo. Luego, Cucrvo y Salazar continuaron río abajo de Janos, marchando carla nno por nua orilla, hasta el 30 de aggosto. Sólo se vieron rastros, annque abundantes, y Cuervo había llegado a ciento veinte leguas de Sonora. Renuida junta, la mayor parte de los capitanes estuvieron por continuar la expedición hasta el río del Norte, del que sólo distaban ya quince o veinte leguas, suponiendo que las fronteras de Sonora y Casas Grandes habían quedado bien defendidas y que no sería fácil volver a rennir 111 contingente de tropas como el que en aquella ocasión se hallaba sobre el terreno. Pero Cuervo, viéndose tan lejos de su jurisdicción y con noticias de que su sucesor ya se hallaba en camino, y teniendo además complicaciones si entraba en Nuevo México, don-

I 20 Ibicl. fols. $18_{7}-194 \mathrm{~V}$. 
de había gohernador y capitán general, resolvió regresar con una pequeña escuadra de españoles y treinta indios, siguiendo el derrotero de la Sierra Coaguillona y puesto de Batepito, hasta Teuricachi; mientras que Fernández de la Funte, con todo el resto del campo de Sonora, continuría unido a Ramírez hasta el río del Norte y, si no hallasen enemigo, volvería por Casas Grandes y las sierras de los sumas y conchos. Y se despidió Cuervo dando a todos las gracias por el esfuerzo hecho y prometiéndoles en nombre de Su Majestad recompensa para tan señalado servicio, yendo a entregar el mando de la provincia en paz a su sucesor. ${ }^{\text {I2I }}$ Mediado octubre, todavía seguía Fernández de la Fuente en campaña con la gente de Sonora. ${ }^{\text {r } 22}$

\section{California, LA SIERRA y EL PIRATA}

Mientras Cuerro había hecho frente a la delicada situación de Sonora, Atondo había llevado a cabo la más seria tentativa de ocupación de California. El I7 de enero de $I_{68} 3$ se hizo a la mar la armadilla construida por el almirante y compuesta de dos naves - la fragata almirante "San José" y la balandra capitana- y un patache. Los barcos de Sinaloa no abordaron a las costas californianas del puerto de La Paz hasta el $r{ }^{\circ}$ de abril, y allí saltaron a tierra veinticuatro soldados "juntamente con los de Sinaloa". El viejo presidio de Díaz y Hurdaide cumplía una misión ultramarina, de la que Sinaloa era astillero, base de partida, cuartel y centro de aprovisionamiento. Atondo había dejado a su cabo y caudillo del presidio, Juan Antonio de Anguis, en el Yaqui, con el encargo de reunir bastimentos, que pronto fue la capitana a buscar. Precisamente el retraso en volver de esta nave fue una de las causas de que la expedición regresase en julio a la costa del continente.

I 2 I Ibid. fols. I 95-201.

I 22 Interrogatorio para descargo de Cuervo en su residencia, San Juan, I9 octubre I684. Escribanía, $400 \mathrm{C}$, pieza I, fols, 58-59, pregunta 6." 
La empresa se acometió con renovados bríos dos meses després. Fi 6 de octubre desembarcó Atondo en la península y fundó el real de San Brtno: esta segunda tentativa duró catorce meses, subsistiendo los dos establecinientos - -se había añadido el de San Isidro-gracias a los continuos viajes de las naves al Y aqui para traer caballos, ganaclo vacuno, granos, etc.

El primer viaje del almirante, en agosto de $168_{4}$, ya no encontró at Anguis en Sinaloa, porque el caudillo, obedeciendo a las instancias que acababan de hacérsele de Sonora, había teniclo que pasar con la tropa a aquella frontera. ${ }^{123}$ En diciembre de 1684 , descorazonado por las escasas posibilidades de subsistencia que ofrecia el país, con la mayor parte de sil gente enferma, Atondo hubo de renunciar a mantenerse en la peninsula y resolvió retornar a Sinaloa, y aunque la junta habida en México y el Consejo de Indias fueron de parecer que se conservasen los dos puestos fundaclos por el almirante, de hecho quedaron abandonados.

La ausencia de Anguis y su tropa - que no llegó a intervenir en las campanas de Cuervo- de Sinaloa no debió durar muchos neses, pues estaba allí en el momento de tomar posesión del gobierno de la provincia en el presidio de la villa, llamado "de Cadereita", en is de mayo de 1686 , el nuevo alcalde mayor, Terán, I24 a quien él entregó el bastón y que, aparte el famoso motín ocurrido en el real de Paredes, tuvo un gobierno bastante agitado. Insertamos a continuación el título de teniente de capitán general de Sinaloa que Paredes despachó a Terán ${ }^{125}$ por ser el más antiguo que hemos hallado.

"Don Carlos... Por cuanto en la villa de San Felipe y San1tiago, fuerte de Montesclaros, de la provincia de Sinaloa en la Nueva España hay prevención de gente de guerra para defensa de las poblaciones que habitan indios gentiles de diferentes naciones rebeldes y al presente estáis proveído vos el capitán Don

I 23 Patronato, 3I, ramos $70^{\circ}$ y $80^{\circ}$

124 Escribanía, j\&i $B$, fol. 66 .

125 Ibicl, fols $34-3 \% \mathrm{v}$. 
Domingo Terán de los Ríos por gobernador capitán de ella y conviene que en dicha provincia laya un teniente de capitán general así para el gobierno de las armas como para el reparo de los accidentes que se pudieren of recer en su contorno, jurisdicción y costas del Mar del Sur, y que sea persona de satisfacción, calidad, práctica e inteligencia que se requiere en casos militares, atendiendo a que en la vuestra concurren estas y otras muchas necesarias para este ministerio y a que me habéis servido más tiempo de veintiséis años en mis reinos del Perút en el puesto de alférez de una de las compañías que por el año pasado de i66r se levantó en la ciudad del Cuzco para el reino de Chile, de que os mandó despachar patente el conde de Santisteban mi virrey que fue de aquellas provincias y gobernasteis la dicha compañía por reforma de vuestro capitán Don Felipe de Aranzana, quedándoos por protector de los naturales de aquel partido, descle donde fuisteis a la villa imperial del Potosí cuando el pirata inglés entró en el castillo de Chagre y ciudad de Panamá sentando plaza de vuestra espontánea voluntad, bajando a este socorro que continuasteis desde 6 de marzo del dicho año de 66r hasta que se agregó toda la gente de las compañías al gobernador Don Francisco Narriondo que lo era de aquel presidio y os apuntaron la plaza a los $2 \mathrm{I}$ de julio de él en virtud de decreto del dicho mi virrey, cumpliendo en todo con las veras de vuestro valor, como asimismo en la averiguación de la causa a que os envió el dicho gobernador sobre las heridas que se habían dado al licenciado D. Juan de Castro Sotomayor, presbítero, y comisión que os despachó contra los salteadores y delincuentes de aquellos parajes, de que disteis muy buena cuenta, como también para que se manifestase en mi real caja de la ciudad de Nuestra Señora de la Paz los oros de las minas de aquel distrito que se extraviaban y sustraían de manifestar, como todo consta y parece de los títulos, papeles, certificaciones y fes de oficios que demostrasteis al conde de Paredes, marqués de la Laguna, pariente, de mi Consejo de Cámara y junta de Guerra de Indias, mi virrey gobernador y capitán general de la Nueva España y juez de la real 
audiencia de la ciudad de México, con cuyo reconociniento os despachó patente a los 7 de agosto del año pasado de 1682 de capitán de infantería española de la que se había de levantar en la nueva cindacl de la Veracruz para reclutar la dotación de la real fuerza y castillo de San Juan de Ulúa por que os mandé despachar mi real cédula a los $i_{5}$ de febrero del año de 1683 recomendando vuestra persona al dicho mi virrey para que os proveyese o ocupase en los cargos políticos y militares de ste provisión, en cuyo cumplimiento os ha hecho merced del referido y yo lo he tenido por bien y esperando como espero de vos el dicho capitán Don Domingo Terán de los Ríos y de ruestras muchas y honradas obligaciones continuaréis en mi real servicio con acterdo del dicho mi virrey conde de Paredes de la Laguna, por la presente os elijo y nombro por teniente de capitán general de la dicha provincia de Sinaloa, sus presidios y costas del Mar del Sur de ella por el tiempo que sirviereis la plaza de mi gobierno capitán de la gente de guerra de ellos y fronteras de sul distrito, usando este cargo en todos los casos y cosas anejas y concernientes segín y como los han usado, podido y debido usar vuestros antecesores y como lo han 11sado, y ejercido los demás tenientes de capitán general de las provincias de la Nueva España, guardando las órdenes e instrucciones del dicho mi virrey con la vigilancia y cuidado que fío de vos y conoceréis de gutrra, corrigiendo y castigando los excesos que se cometieren precediendo información breve y sumariamente a usanza de guerra, otorgando las apelaciones que conforme a derecho y leyes militares se debieren admitir, y mando al caudillo y soldados de los dichos presidios de Sinaloa y a los demás oficiales y ministros de guerra os acaten, respeten y obedezcan guardando vuestras órdenes a los plazos y con las penas que les pusiéredes que habéis de ejecutar en los rebeldes e inobedientes, que para todo ello y gozar de las honras, gracias, preeminencias, exenciones, prerrogativas e inmunidades que por razón del dicho cargo de teniente de capitán general debéis gozar os doy poder y facultad cual de derecho se requiere y por esta ocupación no os señalo sueldo alguno respecto de que 
habéis de percibir por la de gobernador y capitán de la dicha gente de guerra. Dada en México a 2 de febrero de 686 años. El conde de Paredes, marqués de la Laguna”.

Pasemos a ver las incidencias de su mandato. En I687 fue llamado por los Padres misioneros de Chínipas, cuyos indios habían recibido tlatole de los tarahumaras de Papigochi para hacer juntos una sublevación. Llegado el aviso a la villa de San Felipe y Santiago un día a las siete de la noche, doce horas después partia Terán para la sierra al frente de ciento noventa y tres hombres, entre soldados, milicianos y auxiliares. Los chínipas y guazapares quedaron muy atemorizados al ver la presteza con que llegaba este socorro, Terán ajustició al tlatolero y a los cinco cabecillas de la conjuración, y la tierra quedó en paz y sometida, al cuidado de sus misioneros, presididos por el P. Salvatierra. ${ }^{\mathbf{2} 6}$

Poco después se presentó nuevo peligro, menos frecuente, en forma de agresión pirática. Hubo, efectivamente, una incursión pirática por estas latitudes del mar del Sur en los años r687 y 1688, y fue en esta ocasión cuando Acaponeta padeció asalto y saqueo. ${ }^{127}$ En 1687 , a poco de regresar de su incursión a Chínipas, fue avisado Terán que el pirata estaba en el Yaqui, como que llegó a desembarcar en este lugar. A toda prisa se encaminó con cien hombres a rechazar esta agresión, lo que consiguió con sólo hacer acto de presencia, pues el pirata se hizo rápidamente a la mar. El alcalde mayor puso vigías y centinelas por la costa, y sus precauciones no fueron baldías, puesto que en agosto de 1688 de nuevo se dio la alarma en el Yaqui. Segunda vez acudió Terán con un trozo de tropas, y armó a los indios y los tuvo preparados, hasta que se supo que el pirata se había alejado de aquella costa, que él fue reconociendo a su regreso a la villa. ${ }^{\text {r28 }}$

Según se dijo con anterioridad, a Terán sucedió el primer

I 26 Respuestas al interrogatorio de descargo de Terán en su residencia. Escribania, $390 \mathrm{~A}$, fols. $9 \mathrm{v} .-53 \mathrm{v}$, preguntas 7 : $^{\mathrm{A}}$ y $160^{\circ}$

I 27 Bandelier, II, 230.

128 Escribania, 390 A, fols. 9v.-53v. pregunta 16." 
alcalde mayor o gobernador vitalicio de Sinaloa, Quirós, y en su tiempo persistió la amenaza por mar a las provincias, segtín escribió el presidente de Guadalajara, Ceballos Villagutierre, al rey, en mayo de I690, I20 diciendo que, cuando ya llevalsa el pirata del nur del Sur muy cerca de cuatro años en la costa y puettos de Nueva Galicia y Nueva Vizcaya, ordenó el virrey conde de Gálvez saliese a combatirle un navio peruano que había llegado a Acapulco. Este navío batalló con el pirata, que se dio a la fuga a vela y remo, escondiénclose en las islas Marias, según después se supo; el pertano le buscó y volvió a Acapulco sin hallarle. Luego, el pirata se dejó ver en la isla del Palmito, cercana al real y minas del Rosario, y en otras partes de aquella costa. Galve envió contra él a don Andrés de Arriola con tres navios que lo buscaron sin éxito. No volvió a producirse alarma, aunque se signió manteniendo la vigilancia, y el presidente-gobernador pidió un donativo en todo el distrito de la audiencia -quitadas las alcaldias costeras-- para sufragar los gastos ocasionados, y la iniciativa halló tan buena acogida que se recaudó algo más de lo gastado. Hay constancia de un libramiento de 1.725 pesos hecho en 19 de diciembre de 1689 para bastimentar y equipar a los vecinos del real del Rosario, que debían estar a punto para rechazar la temida invasión del pirata. ${ }^{\text {I30 }}$ Su presencia daría pretexto a Quirós para regresar de Ostimuri: "Hay -dice Juan María Salvatierra, S. J.- dos navíos de alto bordo en la costa del Sur, hacia la de Tepic, dicen que desembarcaron al intérprete Carlos y hacen todas las diligencias para topar con el capitán Francisco...". "13 Luego, repentinamente, se hizo el silencio sobre el pirata, el temiclo pichilingue, que se desvaneció en el Pacífico.

\section{Quirós y la rebelión de Ostimuri}

En abril de I69o ardió en Yepómera la primera chispa de la

I 29 Celallos a S. M., Guadalajara, 20 mayo I69o. Guadalajara, 23.

I30 Certificación con carta de Ceballos a S. M., 28 mayo i693. Guadalajara, 25.

I,31 Salvatierra a Pardiñas, s. f, Patronato, 236, ramo I,0, fols. I83-185. 
rebelión de los tarahumaras; como en tantas otras ocasiones, los acontecimientos del interior tenían una especial resonancia en las alcaldías costeras, resonancia que esta vez acusó el naciente y próspero Ostimuri. La sublevación de los pimas bajos que ocupaban las vertientes orientales de la Sierra Madre, en contacto directo con los tarahumaras, tuvo entre otros efectos, el de impedir que pasase a actuar en la frontera de Sonora el presidio de Sinaloa, que desde fines del año anterior se preparaba para hacerlo.

Es sabido que el segundo acto de lo que en términos generales se llama la rebelión tarahumara consistió en la muerte del P. Manuel Sánchez y del capitán don Mantrel Clavero, cuando aquél volvía de predicar en el real de San Nicolás; estos crímenes fueron obra de los pimas, según la impresión que recoge el recién nombrado alcalde de Sonora, comisionado por el gobernador Pardiñas para nombrar justicia en Ostimuri. Castillo designó a Capelo, que se venía dedicando a la minería en el real de Bacanora, y Capelo aceptó "por desear la paz de los reverendos Padres de esta jurisdicción y la de los vecinos"; a poco, "el día que se hizo el ajuste y compromiso del capitán Guadianeche tuve razón de que Ostimuri lo habían quemado", y también de los alborotos de Yécora y Maicoba, Tapipa, Taraichi, Teopari, etc.; los pimas, seguidamente, "se convocaron y juntaron como siete leguas de este valle - Capelo escribe desde Sahuaripa - 132 en el peñol inexpugnable para asolar este real de Tacupeto, y que pasaba la junta de más de 1.500 indios, y hallándome con poca gente y ser el riesgo declarado y no tener satisfacción de los pueblos de Arivechi y Sahuaripa, porque se reconoce estar todos convocados...". El justicia de Ostimuri menciona con algún detalle los motivos de esta convocación: "por los daños que han recibido de los vecinos en quitarles sus tierras y poblarlas de caballadas y ganado mayor y haberles sacado al trabajo de dos años a esta parte con exceso... y los vecinos más principales de este valle, que es Pedro Coronado y Isidro de Quesada

I 32 Capelo a Pardiñas, Sahuaripa, 20 abril 1690 . Patronato, 236, ramo $10^{\circ}$, fols. 79-82. 
se lallan para despoljar por razón de que tienen mucho ganado y caballada y parte que esto ha ocasionalo algunas molestias que recibian los indios sin poderlo remediar los daños, pues los indios no podian sembrar stis tierras porque las bestias les hacían daño y les conian sus milpas, por cuya razún parce se ha despoblado el pueblo de Onapa y un indio llamado El Junari, capitán getneral que era de toda la Pimería, se alzó y, según parece, anda capitáneando toda esta Fimería, y ne parece conveniente que estas dos familias salgan a la parte que les pareciere porque no pierdan sus haciendas, y támbién porque lós pueblos que hán quedado no se les lagan daños y se sigan otras ruinas". Comó últina causa del peligro que pasaba Ostimuri apuntaba "la poca unión de los vecinos, que siempre han vivido abanderizados, sin que haya habido conformidad ni nadie lo ha podido remediar". Quirós recoge más adelante la mención de los abusos en los sellos y en las tierras y da como cierto que más o menos el estado de rebeldía se remontaba a tiempos anteriores, "y en particular en tiempo que administró justicia don Juan Francisco Guadianeche y sus tenientes". ${ }^{\text {I33 }}$

Las noticias que daba Blas del Castillo dos días después que Capelo, desde Nácatobori, eran que él súlo disponía de veinte arcabuces y unos treinta vecinos sin pólvora, balas, ni cueras, y como doscientas mujeres. Cuando, después del primer chispazo, se retiró con los vecinos a la zona de Arivechi y Sahuaripa, supo el alzamiento ocurrido en Nacori y Teopari, cuando él había de volver a Sonora para defender su frontera setentrional. ${ }^{\text {I } 34}$ Para Castillo, todo se perdía por no haber conseguido que viniese el presidio, estando la provincia totalmente inerme ante la sublevación, "por ser caso impensado y que en esta provincia descle que se pobló no ha habido ninguna guerra, ni levantamiento en estas fronteras". ${ }^{135}$

El caso es que los alzados pusieron fuego al real de Tacupeto,

133 Quirós a Pardiñas, Arivechi, \& julio 1690. Ibid, fols, 259-26I.

134 Castillo a Parilinas, Nacatobori, 22 abril 169o. Ibid., fols. S2-84v.

13z Así lo asegura Capelo en certificado dado a Quirós. Arivechi, 28 mayo [6ou. Ibid., fols. 310v.-3I3. 
abandonado ya por sus pobladores, y que resultaron falsas las paces que intentaron estipular Castillo y el P. Lombardo. El riesgo de despoblamiento por parte de los comerciantes y mineros era cierto, toda vez que nadie podía garantizarles una solución duradera del conflicto y a ellos les llegaba ya en un momento en que nada les quedaba que perder en un Ostimuri paralizado en su habitual explotación minera. ${ }^{136}$ En cuanto a los antecedentes de la sublevación, la pluma del P. Salvatierra escribe: "el presente alzamiento es el mismo y con las mismas circunstancias y cabezas que descubrió tres años ha don Domingo Terán y el P. Nicolás de Prado y el cabo del presidio de Janos, lo cual todo fue en tiempo del Sr. Don José de Neira". ${ }^{137}$

Afortunadamente, el foco rebelde quedó desde el primer momento perfectamente localizado al este de Ostimuri, entre el curso superior del río Mayo y la gran curva del Yaqui en el límite con Sonora. Los cuatro partidos de la misión de Chínipas-Loreto, Chínipas, Guazapares y Cerocahui con Cuiteco-, donde Salvatierra acababa de ser nombrado visitador de Sonora y Sinaloa, se encontraban tranquilos; en este distrito, Pedro Martínez de Mendíbil, alcalde mayor del reciente real de Monserrat de Urique, había reunido un puñado de españoles y se había situado en Loreto, para evitar la expansión del núcleo sublevado. Sin duda la inmediata presencia de Castillo, aunque volvió pronto a Sonora, en Tacupeto, y de Quirós, que estaba en el real de los Frailes y acudió inmediatamente con cincuenta hombres, mitad presidiales, mitad vecinos, y ciento setenta yaquis, hicieron mucho para localizar el incendio. ${ }^{138}$

Quirós, desde Frailes, entró por Nuri, que dice pacificó aunque es dudoso que se hubiera alzado, y tuvo un pequeño encuentro en el peñol de Tepoca, donde hizo cuatro bajas a los pimas y recuperó casi doscientas bestias y reses. A poco se le huyó la mayor parte de los auxiliares, quedándole sólo treinta. Desde Nuri debió

I 36 Doc. cit., en nota 132 .

I37 Salvatierra a Pardiñas. Cerocahui, 29 junio r69o. Ibid., fols. 195v.-197.

r 38 Salvatierra a Pardinas, s. f., y Cerocahui, 24 abril I690. Ibid., fols. 74-78. 
Quirós seguir en dirección a Yécora, para cloucle había citado a la gente de Arivechi, pero cambiando de planes se dirigió a Onavas, con ánimo de asegurar su tranquilidad, y hastá el I de mayo no entró en Arivechi. Esta modificación del itinerario tuvo cono frutos la pérdida de una buena oportunidad para atacar la junta dé los rebeldes en las proximidades de Yécora, y la pruesta en peligro cle la escradra de veinte espanoles que siguiendo sus úrdenes había salido de Arivechi para converger sobre aquella concentración de pimas. ${ }^{139}$ Una rez en Arivechi, Guirós se procuró monturas para sus soldados, que el que menos tomós dos caballos, y marchó a Yécora, emprendiendo la persecución de los alzados por Haros, Sura, Guaguasar:a, Mataraichi y Tapipa, hasta el it en que hubo de detencrse porque los pimas se habian retirado a las barrancas de Haros, donde las cabalgaduras no podian entrar. Regresaron, pues, Quirós con su gente y los veinte hombres de Ostimuri mandados por el teniente de alcalde mayor Francisco Ramos, pasando por el real de Ostimuri, donde recogieron los restos de las alhajas de la incendiada iglesia y algunas herranientas de la hacienda cle Doningo de la Faz, y arrearon hacia Arivechi algún ganaclo que quedaha en Ostimntri y en Yécora. El 27 se celebró en Arivechi junta de los vecinos de este pueblo y del de Sahuaripa, que hallándose nuty necesitados estaban decididos a volver a poblar el real de Táctupeto; pero como necesitasen allí escolta de quince hombres, Quirós se negó al proporcionarla y el proyecto se hundió. I 40

En cambio, estaban en marcha algnumas diligencias para la pacificación. Cuando Quirós venía de regreso de su anterior batida, el zo de junio se le presentó Pedro, sobrino del jefecillo Jumari, que le enviaba a decir que, a cambio del perdón, entregaría a los asesinos del P. Sánchez y Clavero. Quirós admitió la propuesta, cándole término hasta el 7 de julio para que acudiese a Arivechi. En este día se presentaron doce familias de Onapa avisando que el Jumari tardaría tres días más en llegar con los gobernadorcillos

I39 Ilid. fols. I97-190, 296-299 y 303r.-310y.

1te Ibicl. fols, 209-301, 197-199. 
de Tapipa, Taraichi, Mataraychi y Yécora: se suponía que sólo los indios de Maicoba eran culpables. Pablo el Jumari se presentó, por último, el iz de julio, con otros jefes pimas, conducidos todos por el P. Lombardo. Salió Quirós con el estandarte real a recibirlos, oyeron misa, y luego el capitán de Sinaloa los envió a Capelo para que le diesen la obediencia, y Capelo les puso la mano sobre la cabeza. La declaración que el Jumari hizo ante Quirós cita el incidente habido entre los conchos de Yepónera y el alcalde mayor de Cusihuiriáchic, que fue la señal para el levantamiento de la Tarahumara, y las muertes de Sánchez, Clavero, tres arrieros y cinco españoles por los indios de Maicoba; dice que sólo este pueblo y los de Mori, Yepachi, Suari y Muiderrama se habían sumado a la rebelión; y alıde a las milpas que se les obligó a sembrar y los robos de ovejas, carneros y maíz a que se les sometió en tiempos del alcalde Guadianeche. El ig de julio Quirós se disponía a salir segunda vez a campaña contra las cinco rancherías o pueblos que acabamos de citar. ${ }^{\text {I4 } \mathrm{I}}$

La guerra dturaba ya más de tres meses, habiendo empezado de manera fulminante y devastadora para las misiones y los españoles - habían sido destruidos los templos y casas del real de Ostimuri, Onapa, Taraichi, Tapipa y Yécora, y las muladas, ganados y caballadas de Ostimuri, Tacupeto, San Nicolás, Santa Ana y El Valle-, y se había formado una opinión hostil a Quirós y sus métodos. Basta leer el auto suscrito por Capelo en Sahuaripa el mismo ig de julio, ${ }^{142}$ en que asienta que en los pueblos no quedaban más de diez hombres, porque los más se habían huido y los otros se habían marchado sin licencia, pues habían quedado arruinados por los ataques y por no haberse podido poblar las minas. Cinco días más tarde, el teniente de Capelo, Bernardo Fernández, dirigía un largo informe sobre lo ocurrido al gobernador de Parral, Pardiñas, ${ }^{\text {I43 }}$ y en él no se muestra nada favorable a Quirós.

I 4 I Ibid. fols. 259-26I, 30I, 26I-262 y 30IV.-302.

I 42 Ibid. fols. $302 \mathrm{~V} \cdot-303$.

I 43 Ibid. fols. 303v. -3 Iov. 
"Dicho justicia mayor - escribe- es de buenas partes y calidades, conno dicen, a lo de 'Castilla la Vieja, sencillo y sin malicia, amigo de dar gusto a cuanto le persuaden". Pero decía haber traído diecintreve vecinos de los Frailes a su costa, siencto así que no había comprado nada para ellos, "sustentándose de los partidos, y principalmente de este de Sahuaripa, que pertenece al P. rector Domingo Miguel, pues ha dos meses que dicho capitán con toda su compañía residen y viven en la estancia de dicho partido, en el mismo valle, entre este preblo y el de Arivechi, en donde ha tenido el rodeo de dicha estancia de su mano, y no contentos con ganado de rodeo han muerto vacas chichiguas, cabestros y bueyes de arada, y otros daños mayores que los soldados han hecho y hacen, que para solo ello salen de dicha estancia a los pueblos, quitándoles a los natuiales de ellos lo que tienen, y en las milpas los frutos de ellas, sirviéndose no sólo de los caballos clel partido, sino también de los de los naturales, no escapándose los de los vecinos, por no tenerlos propios". Quirós era descle luego de la teoría de que los Padres estaban obligados a sostener al presidio todo el timpo que permaneciera en campaña; por lo menos así había sido siempre. E1 P. Miguel le abastecía de harina, pero $n o$ quería que esto se entendiera precisa obligación. "Pasada ésta, por lo que tengo experimentado y ódlo a muchos, primero se dejarán matar a manos de los pimas de volver a llamar a dicha compañía".

Fermández se mofaba de la primera campaña de Quirós, por los caminos usados, "con clarín por clelante y clarín por detrás". Lo acusa de buscar pretextos para rehuir los combates y de presentarse como superior a Capelo en lo militar como en lo político, estando en su jurisdicción, diciéndoles a los indios que él es el capitán grande, y también que ya no habría más sellos. En otro pasaje entra a cuestiones más profundas: "También solicitan y pretenden embarazos por debajo de cuerda, como dicen, de que no haya vecindad española ni que se pueblen las minas. De este sentir es el Rdo. P. Natal Lombardo, y no es juicio temerario, que es público y notorio y todas sus acciones lo confiesan pues 
también ha hecho rogativas a Santa Rosalía para que falten las minas y metales; quien también no ha tenido pío afecto a las justicias de estos tiempos, pues ha procurado hacerle los desaires que ha poclido, y en el que se ha hecho al justicia mayor que refiero arriba es parte su paternidad, pues siendo instrumento principal de dichas paces persuadió a dichos indios la diesen sólo al capitán don Diego de Quirós, y los dos están tan unidos según las demostraciones en un misno intento ptres los dos, no tan solamente no han ayudado a que se poblase el real de Tacupeto, sino que han solicitado lo contrario y no cooperado a ello, pues dicho Padre muy enojado a voces en público dijo que se obre, que la justicia había de impedir a los vecinos que se saliesen, que eran leyes inicuas y que no lo podía hacer, que se saliesen y se fueran, que el rey no permitía vejaciones a sus vasallos". Así, continúa Fernández, metiéndose el P. Lombardo en lo que no le importaba, había impedido el poblaniento del valle de Tacupeto; hubiera bastado que la compañía de Quirós se situase allí, gozando de la misma ociosidad con que se había manteniclo en la estancia del valle de Arivechi.

Bernardo Fernández tacha de falsa la noticia de que sólo quedasen alzadas cinco rancherías, cuando una ranchería tenía, cuando nás, cuatro familias y menos de diez indios de pelea. Para acabarlas no hubiese tenido que pedir a Capelo para salir segunda vez treinta hombres y doscientos auxiliares. Todo un coro de voces se unía a la del teniente de alcalde mayor. El P. Domingo Miguel, que soportaba a la compañía, decía que causaba más daño, que si fuesen pimas. Pedro Martínez de Mendibil, desde Frailes, concordaba con él acerca del mal estado de la tropa e informaba al virrey y a Pardiñas que se temía una sublevación en el Yaqui, Mayo y Fuerte.

Salvatierra y el Padre Juan de Meneses, misionero de Mobas, también se manifestaban adversarios de Quirós. El segundo padeció el 4 de agosto un motín en Nuri, con muerte del mayordomo, escarnio de las ceremonias religiosas y demostraciones de 
apostasía: "esto dice el capitán Quirós que es nada, no lo dijera Lutero, y que de paso se puede componer". ${ }^{\text {I4t }}$ Tal vez tuviera razón el capitán al explicar. ${ }^{4} 5$ que todo se debía a que el Padie había puesto un mayordomo de su gusto, pero no del de los indios. Salvatierra no se extrañaba del comportamiento de los soldados: "He sido testigo ocular de semejantes casos cuatro años ha en la entrada de clon Domingo de Terán a Chínipas, y el escándalo mayor que tuve fue ver que el mismo capitán decía que no lo podía renediar; y si se deja vivir los soldados como amotinados, mejor será quedarse sin presiclio, pues tanto se pierden los reinos por los enemigos como por los soldados amotinados". "i46 Sin duda los Padres consideraban que este asunto se podía arreglar, pues precisamente importunaban a Pardiñas pretendiendo tener una escolta de doce soldados en cada misión de la Tarahumara. Por último, también el P. Miguel, a petición de Salvatierra, hizo narración a Parclinas de la ineficacia de Quirós: ni siquiera se habían pedido a los alzados las muladas y caballadas que habían quitado a los vecinos, ni siquiera se habían rescatado y sepultado los cuerpos de los muertos. ${ }^{4} 4$

Por su parte, Quirós debió salir de Sahuaripa el iz de agosto, pero fue para ir al puesto de Berapa, junto a Arivechi, donde querían establecerse los pimas del Jumari de Onapa, y dos rancherías del Carrizal y Tepoca. En tolal eran setenta fanilias, a las que di.o posesión el 24 de agosto, dejándolus al cuidado del P. Lombardo. E1 29 le dieron la obediencia en el real de Ostimuri los pimas de Tapipa, Taraichi, Río de los Mulatos, Coradepe, Sura, Guaguasar y Mataraichi. E1 2 de setiembre fue recibido por los indios de Yécora, a los que el 9 se habian unido algunas familias de Maicoba, Muiderrana, Los Pilares, Tucapa, Nuri y algunos tarahumaras. En todos estos pasos le acompañaron Lombardo y

I 44 Ibid. fols. $333-339$.

I 45 Ibid. fol, 33 I.

I 46 Ibid. $340 \mathrm{~V},-342 \mathrm{~V}$,

I 47 Ibid. fols. $442-444 \mathrm{~V}, y$ 449-450. 
Capelo, quien además certificó que hacía dos meses que se trabajaban ya algunas minas y que dos recuas habían transitado el país sin necesidad de escoltas, acompañadas por los mismos pimas. ${ }^{148}$

Como quiera que fuese, las cartas adversas a él habían causado efecto. Pardiñas le escribía indignado por el suceso de Nuri de 4 de agosto. "Si vuelvo el rostro a que Maicoba está intacta, sin haber visto las armas de los españoles, no me espanta el que cada día haya tales insultos, porque a dieciséis o veinte leguas de las fronteras no se logra el empleo de las armas con estos géneros de gentes". ${ }^{149}$ Quirós se justificó asegurando que el suceso de Nuri se había reducido a la muerte del mayordomo mestizo, que realmente había causado muchos daños a los indios; y que si no fue a Maicoba fue, al principio por estar crecido el río, y más tarde porque no podía moverse hasta que no acabasen de bajar de las sierras los indios que iban a pedir la paz. Pero finalmente había dejado expeditos los caminos hasta Tutuaca y había logrado se trabajasen las minas de Tacupeto, real que si no estaba poblado era porque la mayor parte de la vecindad se salió. Dice Quirós ser bueno se trabajen las minas para alivio de los gastos del rey, "mas no es caso de decir a V. S. que hay minas que destruyen lo aumentado y pierden lo ganado si en ellas no se usa de los medios que se deben prevenir como por mí se han prevenido". Ignoramos qué medios son los que aquí menciona. Por estas fechas Quirós preparaba una entrada por el río de Macoyahui con objeto de "reducir a dos misiones la gentilidad hasta Moris" y de capturar a dieciocho indios pimas, culpables de las muertes de Maicoba y Tutuaca, que andaban por las inmediaciones del real de Ostimuri. En cuanto a su renuncia a ejecutar castigos duros contra los naturales, Quirós alega tener orden del virrey para no proceder a ninguno hasta que, vistos los autos sobre los acontecimientos, se le dé el aviso de lo que parezca oportuno; y además, "los que tienen oficios políticos, como no andan de continuo las sierras, atienden sólo a los sellos, y luego

148 Ibic. fols. 417-424v.

149 Pardiñas a Quirós, Carichic, 28 agosto I 690. Ibid. 263-264. 
se han de baja. (los indios) a frerza de ahorcar ya que tienen sus alhorotos, V.S. sabrá ya de cónde dimanan". r 50

Esta carta parece qute puso la situación bajo una nueva luz y produjo el acercamiento de Pardiñas al alcalde mayor de Sinaloa. Por lo menos, la réplica del gobernador muestra la satisfacción por las esperanzas de paz que Quirós manifestaba, "que es 10 importante, sin atender al celo inconsiderado de algunos que les parece no permanecerá paz sin el derramamiento de sangre que pretenden sus inconsideraclos recelos". El últino párrafo transcrito de Quirós semeja una invectiva contra el alcalcle Guadianeche, citado en otras ocasiones, y quizá contra Capelo o Fernánclez. En cambio, las frases de Pardiñas que acabanos de insertar, ¿no son nua alusión contra Salvatierra y algmos otros jesuitas? Parcliñas agrega algo sobre los motivos de la insurrección de Jumari: "Cójenme tan de susto las noticias que $V_{1 n}$. me da de los agravios que han recibido los indios de esas fronteras que estoy escandalizado, y aunque ahora acudo al reparo enviando a que se hagan las averiguaciones, me espanto de que Vm. no me haya avisado los sujetos que lo han hecho y ios tenientes que han ahorcado indios, para tomar la presta resolución en el castigo que merecen, y así sirvase $V m$. de avisármelo con toda distinción de personas y casos, pues no nos podemos negar a cosa tan justa". Si Quirós informó sobre este particular, al menos tal informe no ha siclo hallado en los testimonios que nos han llegado. Por su parte, en aruella nisma fecha, Pardiñas daba conisión a Francisco de Mendoza, vecino de Nacatobori, para que pasase a Ostimuri a averiguar los excesos que allí se hubiesen cometido contra los indios, con objeto de saber las causas del levantamiento. ${ }^{\mathrm{I}}{ }^{\mathrm{r}}$

De todos modos, las dudas que anteriormente había manifestado Pardiñas sobre la capacidad militar de Quirós, respaldadas por toda la campaña de descréclito emprendida por sus adversarios, había dado sus frutos en México. En Is de octubre de I69o par-

I50 Ihice. fols, $424-428$.

35 I Ibid. fols. $438-442$. 
ticipaba el virrey conde de Galve al gobernador de Nueva Vizcaya, haber resuelto por despacho de aquella fecha que don Juan Ignacio de Castañeda, vecino del real de Alamos, se hiciese cargo del mando de las armas de Sinaloa, mientras Quirós, con la mitad de las de este presidio, pasaba a defender Sonora. Prohibía a éste salir de Sonora sin su licencia y le ordenaba otorgar título de teniente de alcalde mayor al tal Castañeda. ${ }^{152}$ De cualquier modo que fuese, Quirós se había retirado ya de Ostimuri, como que el ro de setiembre había salido de Yécora para si1 presidio, llamado a él, al parecer, por el peligro de que el pirata asolara aquella costa, y dando seguramente por pacificada la sublevación. ${ }^{\mathrm{I}}{ }_{3}$

De los sucesores de Quirós en Sinaloa - Agramont, Rezábal y Fuensaldaña-, sólo el segundo hubo de afrontar nuevos problemas en la sierra. Probablemente el retorno de Quirós a la villa de San Felipe y Santiago dejó inútiles las levas de tropas y envíos de armamentos hechos por el presidente de Guadalajara entre setienbre y diciembre de I690. I54

\section{Rezabal, EN EL MAYo y EN Moris}

El Io de enero de 1697 avisaba el gobernador de Parral, don Gabriel clel Castillo, al alcalde mayor y capitán vitalicio de Sinaloa, don Andrés de Rezábal, que la Tarahumara había vuelto a alzarse, por Papigochi, y le ordenaba entrar inmediatamente con treinta y cinco o cuarenta hombres del presidio, por Tacupeto, y el río de Haros, en dirección al foco de la insurrección, y si hallase a aquellos pimas del tránsito rebeldes "entre sobre ellos a sangre y fuego, pasándolos a cuchillo, sin reservar indio", y si estuviesen tranquilos formaría autos para descubrir los motores del levantamiento, procediendo siempre "sin atender a persuasiones ni a pedimentos para la piedad, pues siempre que ésta se practicare en estas

I52 Ibid. fols. 70-71.

I53 P, Domingo Miguel a Pardiñas, Sahuaripa, I 4 octubre r6go. Ibid,, fols. 442-444V.

I54 Certificados con carta de Ceballos a S. M., 28 mayo I693. Guadalajara, 25. 
provincias se perderán". Castillo daba a Rezábal todo su poder sobre los vecinos y sobre todos los justicias de las jurisdiciones por donde pasare, siempre que no coincidiese con el general Juan de Retani, jefe de las tropas del otro lado de la sierra. ${ }^{15} 5$

De lejos se advierte la diferencia de criterios entre Padinas y Castillo para entender un levantamiento. Por otra parte se notará la extraordinaria importancia del hecho de la fidelidad del pueblo ópata - un indigenista diría traición o insolidaridad racial- de modo que cualquier contagio de sublevación tarahumara podía localizarse vigilando sólo la frontera de Tacupeto o de Ostimuri. Finalmente anotemos los plenos poderes dados a Rezábal "como a tan gran capitán”, dice Castillo. Rezábal, además de haber servido en las armadas reales en España, era efectivamente un soldado experimentado y acreditado en las conducciones de tropas y campañas de Nuevo México de 1676 a 1680 , en las operaciones de Cuervo desde Sonora en I68 I y 1684, y en otros incidentes posteriores de la frontera de Sonora, y además gozaba al parecer del afecto de los indios; se decía "persona independiente, con caudal propio", soltero y sin parientes, minas, ni haciendas en Sonora y Sinaloa. $\times 56$

Llegada a Sinaloa la alarma de Castillo, Rezábal envió por delante a Tacupeto al cabo y caudillo de su presidio, con veintidós soldados, disponiéndose a seguirle con el resto de la compañía. El cabo Nicolás de la Higuera llegó a Yécora y no halló novedad, y continuó su marcha hacia Moris y Haros. ${ }^{157}$ Sabiéndose ya la tranquilidad que habia en el oriente de Ostimuri, cuando Rezabal se dirigía a unirse con su cabo, los vecinos y mineros de Alamos le requirieron el 25 de febrero para que pusiese remedio al despoblamiento de las misiones del río Mayo, cuyos indios se habían salido de sus pueblos tiempo atrás, puesto que ya en 16 de diciem-

155 Castillo a Rezábal, Parral, to enero i697. Autos de Fuensaldaña-Rezábal, núm. 3, fols. 93v-05. Guadałajara, r54.

T56 Interrogatorio sobre méritos de Rezábal. Ibid., fols. 56v.-59v.

157 Ibid. $05 \mathrm{r},-96 \mathrm{r}$. 
bre de 1693 lo había connunicado el antiguo visitador jestuita J. Jerónimo de Pistoya al antecesor de Rezábal, Agramont. I58

Rezábal obedeció el requerimiento y visitó el río Mayo, encontrando los pueblos sin casas, pero consiguió reunir y reducir quinientas veintiuna. familias con cuatrocientos ochenta y ocho muchachos y muchachas; luego se incorporaron ciento cincuenta familias más, con otras tantas criaturas. El les ordenó reedificar los pueblos y, para asegurar su subsistencia, hizo donativo de cincuenta fanegas de maíz que se repartieron en Santa Cruz y Echojoa, donde se sembraron milpas de comunidad y se dio nuevo principio a una vida política y cristiana. Luego dio sus disposiciones para que se continuasen y aumentasen las milpas, y se construyesen trojes - de los que una llave tendría el misionero y otra el gobernadorcillo indio- con objeto de evitar que los indios abandonasen sus pueblos empujados por el hambre. ${ }^{\mathrm{r} 59}$

Hasta mediados de junio estuvo Rezábal entendiendo en este asunto, mientras tenía noticia de los primeros golpes afortunados dados por Retana a los tarahumaras, ${ }^{\mathbf{6} 0}$ pero descuidado de la frontera de Tacupeto donde se mantenía la calma, aunque Juan Fernández de Retana le urgía a que entrase con presidiales y auxiliares yaquis en la Tarahumara para cooperar con él en aquella pacificación. ${ }^{61}$ Por entonces había estado temiendo Gironza, alcalde mayor de Sonora, un levantamiento ópata que, desde luego, no se produjo: la intranquilidad, de todos modos, se explicaba, puesto que el i6 de abril se había descubierto una conjuración general de tarahumaras, pimas y sonoras, auxiliados de las naciones de Nuevo México. En aquel momento llovieron sobre Rezábal las llamadas de socorro de Retana, el alcalde y el misionero de Tacupeto, los Padres de Chínipas y hasta el obispo de Durango. ${ }^{{ }^{6}{ }_{2}}$

I5 Guadalajara, I 54 , pieza $44^{\mathrm{n}}$, fols. Iv. $-3 \mathrm{v}$.

I59 Escribanía, $390 \mathrm{~B}$, pieza $24^{a}$, fols, $138-167 \mathrm{v}$.

I6o Guadalajara, 154, pieza $4{ }^{*}$, fols. Iv, $-3 \mathrm{v}$.

I6 I Escribania, $390 \mathrm{~B}$, pieza 2., fols, $\times$ 56-159v.

I62 Guadalajara, I54, pieza 3.", fols. 28-roov. 
El it de junio de r 697 se puso al fin Rezábal en narcha descle Alamos hacia Tacupeto, habiendo añadico veinticuatro hombres a los pocos presidiales - diecisiete- que tenía. De aquella tropa destacó tres hombres con el cabo Antonio de Cosio a Chínipas, nientras ordenaha al teniente que había dejado en Sinaloa reclutase otros veinte soldados. ${ }^{6} 63$ En la frontera de Ostimuri quien más se habia moviclo había sido el alcalde mayor de aquella jurisdicción, José de Zubiate. Cinco complicados en la sublevación habian sido ejecutados. Fl 25 de jumio dieron la obediencia a Rezábal los indios de Maicoba, Moris, Tapipa, Taraichi, Onapa, Teopari, Arivechi y Sahnaripa, y el capitán de Sinaloa creyó llegado el momento de pasar a Yécora, nnisión que alcanzó dos días después: pero había apenas vuelto la espalda cuando se alzaron Maicoba y Moris. Rezábal hubo, pues, de entrar en verdadera campaña. Cinco semanas pasó en Yécora acopiando víveres y esperando trin contingente de doscientos quince yaquis que puso en pie de guerra, y el 5 de agosto salió a campaña, cuando tenía ya ochenta y cuatro prisioneros de los rebeldes capturados por el Jumari y había acogido en Yécora a la mitad del pueblo de Maicoba que había permanecido fiel.

Cuando salió a campaña se dirigió contra Moris, misión recién convertida, cuyos indios le enviaron con embajador los vasos de los Santos Oleos y un ornamento, culpando de los daños a los tarahumaras: Rezábal los halló en un peñol inexpugnable, porque se ignoraban sus entradas. El dispuso a su gente y el I I de agosto comenzó el asalto al salir el sol; en poco tiempo, mientras se ascendían las laderas del cerro, tuvo diez soldados y auxiliares heridos, más el cabo Higuera, que resultó alcanzado por una flecha, y un indio muerto y despedazado. Cuando consiguieron alcanzar más altura, los defensores empezaron a arrojar peñas y piedras: el sargento cayó con la cabeza aplastada por una losa. Pasado el mediodía hubo Rezábal de retirarse con veintidós heri-

Irs Ibid. fol. Iо7-II $2 v$. 
dos, de los que alyumos murieron posteriormente y otros quedaron baldados, por la actividad del veneno de las flechas. Sólo se había conseguido hacer un prisionero, que murió luego, pero el capitán suponía que en 10 alto del peñol los rebeldes debían tener bastantes baịas y de sus caudillos más principales. El experimentaba 111 nuevo contratiempo: "los indios amigos yaquis se acobardaron tanto el primer día que se huyeron, y consecutivamente los pimas altos de estos pueblos..., parientes de los alzados". Rezábal había aprendido ya algo típico de la acción en la sierra: "los caballos en que fuimos desde que comenzó la pelea no nos sirvieron sino de embarazo y ocupar gente en su guardia". I64

Otro día salió Rezábal a reconocer el peñol por rumbo distinto y halló más enemigos, con los que tuvo un largo encuentro a caballo y a pie, y al cabo los rebeldes se retiraron a lo alto del cerro. Al tercer día reaparecieron profiriendo gritos por las cimas de la sierra, pero cuando se inició el ataque se dieron a la fuga. Rezábal clecidió volverse a Yécora: Natora y Taraichi fueron atacados por los insurrectos, mientras él reclutaba nuevos soldados y enviaba diez más de refuerzo a Chínipas, donde el clestacamento de Cossío pasaba gran peligro refugiado en un pueblo con los misioneros. Rezábal sostenía a su costa, en Chínipas y Yécora, cincuenta y dos hombres sobre las armas. Como en tiempos de Quirós, corrían rumores de alzamiento en el Yaqui.

Rezábal pedía auxiliares indios, harinas, herrajes, pólvora, escopetas largas, piedras de arcabuz y cotas de malla y aseguraba que carecía de ganado y de caballada, cosa que no había en parte alguna. Mal abastecida, pues, la tropa, se mantenía en Yécora "obligado sólo a la defensa y guarnición de estos pueblos, hasta que se los lleve el Diablo". E1 P. Luis María Pineli, S. J. informaba desde el mismo lugar que a Rezábal, en efecto, no le quedaba ni un auxiliar, ni un caballo, lo cual no le impedía discutir con Retana sobre el rango superior a éste que pretendía por sus títulos,

I64 Escribanía, 390 B, pieza 2.", fols. 188-190 y 248-249. Guadalajara, I54, pieza $3 .^{\mathbf{a}}$, fols, I07-I I 2 . 
stueldo y antigüedad de más de cincuenta años del presidio de Sinaloa sobre el de Conchos, y sobre ello escribía al presidente Ceballos de Guadalajara, en quien el virrey había delegado la jurisdicción de capitán general y superintendente general de real hacienda para las providencias a tomar en aquel levantamiento de toda la Tarahumara. ${ }^{165}$

Pero mientras Retana corría la tierra de los alzaclos, Rezábal estaba reducido a Yécora, al destacamento de Chínipas y a otro de dieciséis hombres que puso en Onapa para asegurar la vía por donde a él le llegaban los bastimentos. ${ }^{66}$ En octubre adoptó otra actitud, dedicándose a proteger las faenas de recolección que le aseguraban los víveres, y a batir a los enenigos en pequeños combates, mientras el P. Lombardo practicaba gestiones para atraer a los rebeldes a la paz, lo que se logró en noviembre en Taraichi, después que el 29 del mes anterior atacó con pleno éxito una partida de tarahumaras, conchos, natoras, haros y pimas. ${ }^{67}$ En estas circunstancias, los refuerzos en material y hombres que se disponían o autorizaban en Guadalajara empezaron a hacerse innecesarios: como de costumbre, las agitaciones de los indios duraban poco, pues su escasa fuerza no les permitía resistir el acoso continuado de las tropas españolas. Entretanto, Zubiate hacía grandes esfuerzos por conservar el real de Tacupeto, 1legando a socorrer de su bolsa a los siete únicos vecinos que 10 poblaban. I68

Las perspectivas parecían alegres y esperanzacloras cuando, hecha la última recluta de trece hombres en Alamos para reforzar los veinticuatro de Chínipas, y unidos todos con otros veinticuatro enviados por Retana y mandados por su cabo Alday pasaron a recoger los maíces rle ocho pueblos fieles, y luego a talar los de Batopilas, único que continuaba alzado en la sierra. Pero aquí fueron atacados, perdiendo caballada y víveres, luchando el 8 de

I65 Guadalajara, I 54, pieza 3.4, fols. I I 2v.-I I $4 \mathrm{~V}$.

I 66 Ihid, fols. II $4 \mathrm{~V} .-\mathrm{II} 7$.

I67 Escribanía, $390 \mathrm{~B}$, pieza 2. , fols. 275-276.

168 Guadalajara, 54 , pieza $3{ }^{\circ}$, fols. I 24-I 28 . 
noviembre desde el alba a las tres de la tarde y retirándose finalmente a pie. Este desgraciado incidente anuló todos los pequeños éxitos obtenidos con anterioridad, y no parece que se hiciese nada provechoso para dominar a los alzados hasta cuatro meses después. El 9 de marzo de 1698 llegaba el general Retana a Yécora para unirse a Rezábal, que estaba en Arivechi, donde entendia con el P. Lombardo en la pacificación de Taraichi, Tapipa y Natora. El 24, después de ejecutados dos indios rebeldes, se decidió la entrada con junta a Moris con ciento diez soldados y los auxiliares, de los que cien irían a capturar a los que andaban por las sierras de Maicoba y Muiderrama. Retana llegó a Moris el 30 de marzo, y el $\mathrm{r} 4$ de abril estaba de ntievo en Yécora. E1 I. ${ }^{\circ}$ de mayo había alcanzado Taraichi, y de allí se internó de nuevo en Tarahumara para concluir la guerra, mientras Rezábal, con su presidio y veinte hombres reclutados, atendía a defender la frontera de Ostimuri. ${ }^{{ }^{6}}$ Rezábal declara el 22 de julio siguiente, en Alamos, llevar gastados desde el principio de aquella guerra, de su hacienda, diecinueve mil setecientos siete pesos. ${ }^{170} \mathrm{El} 2$ de agosto estaba ya en Sinaloa, diciendo quedaban sosegados Tacupeto y Chínipas y reducidos los rebeldes a sus pueblos, lo que se debe considerar fruto del alarde de fuerza hecho por Retana y por el propio Rezábal, que tenía más de seiscientos auxiliares a su costa. ${ }^{171} \mathrm{Y}$ aunque la sublevación de Tarahumara no quedó concluida sino en I703, en tiempos del gobernador don Juan de Larrea, ${ }^{172}$ no parece que hubiera nuevas inquietudes en los vecinos pueblos de Ostimuri y Sinaloa. El presidio de esta villa no tuvo más novedad que la de haberse concedido su capitanía vitalicia a don Jacinto de Fuensaldaña en 2 de agosto de 1697 por el donativo de mil doblones a dos escudos de oro que hizo a Su Majestad.

I69 Escribanía, $390 \mathrm{~B}$, pieza 2.", fols. $334 \mathrm{v} .-372$ y $377-379$.

I 70 Guadalajara, I 54, pieza $4 \cdot^{\mathrm{a}}$, fols. I5v.-23.

I 7 I Don José Sarmiento a Rezábal, México I6 setiembre I698. Guadalajara, I 54 .

I 72 Escribanía, 39 I $C_{\downarrow}$ fols. I $5^{\text {I-I53. }}$ 
Descle los días de Atondo tenía el presidio de Sinaloa destacados doce a quince soldados en la frontera de Sonora, situados habitualmente en el valle de Teuricachi, pero que en I6go ó I 69 I se trasladaron al ojo de Corodeguachi. Los años de 1688 y i689 se señalaron por los ataques que jocomes, sumas y janos hicieron contra Santa Rosil y Cucpuiarachi. I73 En1 1688 tuvo lugar, además, tnin moviniento de rebeldía entre los pimas altos, moviniento rápiclamente dominado por los españoles. Segúu lo cuenta el gobernador de Nueva Vizcaya, Juan Isidro de Pardiñas Villar de Francos, los pimas, "habiendo negado la debida obediencia que tenían dacla a Vuestra Majestad (aunque gentiles), despoblaron sus invasiones las mejores minas que se labraban en la provincia de Sonora, a la cual prové con gente española e indios auxiliares en mucho número, por ser muly necesarios e inexcusables y la nación rebelada muy numerosa y de mucho valor, que se experimentó con haber acometido en su alojamiento al campo de los españoles e indios auxiliares, con ánimo de que, rompidos los que se les oponían, con mayor faciliclad to harían a toda la provincia, que mediante el haber yo reforzado al alcalde mayor de aquel partido con una compañia de gente española de valor y experiencia resistieron la furia del enenigo y recobrada le apretaron, habiendo habido de una y otra parte muchos muertos, obligando a los rebeldes a apetecer la paz, que se les concedió y se han adentrado en sus pueblos y rancherías pidiendo los más ministro que los instruya en la Santa Fe Católicá (cosa que no se ha podido conseguir en más de cuarenta años). La provincia de Sonora tuvo en esta ocasión el riesgo que padeció Nuevo México, y hubiera sido de las grandes pérdidas que pudiera haber en estas partes, pues fuera de perderse la cristiandad de tantos naturales como tiene reducidos, se destruirían

173 Real Academia de la Historia, Colección Boturini, vol. 16, fols, 1-103v. 
minerales muy ricos y que rinden muchos haberes a Vuestra Majestad en reales quintos". ${ }^{174}$

Aquella pacificación dio lugar a la entrada del jesuita P. Kino en la Pimería Alta, al tiempo que se reemprendían las tentativas para la conversión de los seris. Con Kino, toda la Pimería Alta será definitivamente conocida por los españoles, desde los sobas al río Colorado, y se irá definiendo la frontera de los enemigos apaches que quedan al norte y al este de esta línea. En cuanto a los motivos de la rebelión, parece se debió a la dureza con que el cabo de Sinaloa, Nicolás de la Higuera, castigó a la ranchería de Mototicachi, sobaipuri, con muy trivial causa, según Mange, La gente española enviada por Pardiñas debió ser la compañía de Juan Fernández de la Fuente, que desde Casas Grandes entró al río de Santa Cruz y destruyó pueblos y siembras de los alzados.

Entretanto, Corodeguachi, Tebideguachi, Teuricachi, Cuquiarachi, los pueblos ópatas eran continuamente hostilizados por janos, jocomes, sumas y apaches. El capitán de Janos no tenía descanso y obtenía repetidos triunfos sobre los asaltantes, pero la combatividad de éstos no decrecía, y la sublevación de los tarahumaras en I69o, al obligar a Fernández a reintegrarse a su presidio, dejó en la mayor angustia al vecindario de Sonora. Desde mediados de 1689 , Fernández no había abandonado aquella frontera, con treinta y cuatro presidiales de Janos reforzados por el destacamento de Sinaloa mandado por Mateo Ruiz Limón. En el transcurso de más de ocho meses había hecho dos entradas y varias correrías para dejar en paz a los pimas, que habían recibido de buen grado a los cuatro jesuitas, y a fines de febrero de I6go emprendia la marcha de regreso a Janos. En Nacosari, los capitanes Francisco Pacheco Ceballos y don Juan de Escalante, tenientes de alcalde mayor del valle de Bacanuchi y del propio real de Nacosari le requirieron para que no dejase desguarnecidas aquellas fronteras, que en enero y febrero habian sido muy combatidas, hallándose imposibilitada

I74 Pardiñas a S. M., 2 I noviembre 1688. Guadalajara, 29. Bandelier, II, 230. 
para actuar la escuadra de Sinaloa. Los veintiún firmantes del requerimiento aseguraban que los stmas, jocomes y janos ya 110 guardaban las lunas para hacer sus acometidas, y pedían a Fernández, en ausencia del aicalde mayor Blas del Castillo, que dejase al menos veinte soldados.

Fernández replicó que se le había hecho muy difícil mantenerse en Sonora, por "la poca o ninguna ayuda que para bastimentos hay, pues al presente han cerado la puerta in rotum los Reverendos Paclies en no diarlos como hasta aquí lo han hecho, ni aun llevándoles la plata para que diesen el preciso sustento para que pudiese sustentarl lá gente que al presente tengo de mi cargo, como se verifica por cartas de tres Padres fronterizos de esta provincia, las cuales acumularé en los autos de guerra y en clonde convenga". Sin embargo, el I. ${ }^{\circ}$ de marzo volvió a insistir Escalante con nuevo requerimiento, mostrando la inutilidad de los presidiales de Sinaloa en Tenricachi y la necesidad que Sonora tenía, 110 ya de escolta "sino de presidio redondo", y el capitán de Janos, se avino a dejar a sus espaldas catorce soldados, mandados por el cabo José Rabelo, en Bacuachi. ${ }^{175}$

Cuando Pardiñas lo supo, dispuso que también se retirase este contingente, enviando en cambio Quirós veinticinco hombres de Sinaloa con su cabo. ${ }^{\text {y }}$ Trasmitida la orden por Fernánclez a Rabelo, salió éste hacia Nueva Vizcaya, y cuando marchaba por Basaraca tuvo noticia de que los janos habían capturado y se llevaban toda la caballada de Blas del Castillo; persiguió a los atacantes con nueve hombres, y todos cayeron y perecieron en una emboscada que les tenían dispuesta. Los cuatro soldados restantes, que guardaban la caballada, fueron salvados por don Pablo, gobernador de Bavispe, que acudió con sus ópatas. ${ }^{177}$ Así, pues, quedó destruida la escasa defensa de Sonora, y como Quirós no podía enviar socorros mientras entendía en la rebelión de Ostimuri, Par-

175 Patronato, 236 , ramo ${ }^{\circ}{ }^{\circ}$, fols, $9 \mathrm{~V},-17$.

i 6 Ibid. fols. $24 \mathrm{v},-25$.

I 7 Ibid, fols. $50 y \cdot-54$. 
diñas despachó a Sonora al capitá11 Francisco Ramírez de Salazar, alcalde mayor de Casas Grandes, con algunos aventureros a atender su frontera. ${ }^{178}$ Algo después llegaría a Quirós la orden del virrey conde de Galve para pasar con la nitad de sus hombres a contener a los apaches y sus aliados.

A principios de r69 i corría por Sonora la noticia de que el virrey había accediclo a la erección de un presidio en la provincia. Blas del Castillo la difundió para evitar el despoblamiento total del valle de Bacanuchi, doncle había puesto ocho hombres de escolta. En Bacuachi tuvo que poner tres españoles y treinta indios sobre las armas: éste era el lugar de más riesgo de la frontera. Visitados estos dos puntos, Castillo volvió al valle de Sonora para pasar a la tierra de los seris y tecomacagues que también estaban en guerra.

En Huepac o Guepaca convocó a los vecinos de Sonora y a sus tenientes de alcalde mayor para tener junta ${ }^{179}$ en la que consultarles el lugar más adecuado para situar el presidio, y convinieron en emplazarlo en el Ojo de Agua de la Cananea, donde estaría a punto para contener a pimas, jocones, sumas, chinarras, janos, sobaipuris, apaches y sobas, todos al parecer rebelados; $\mathrm{y}$ además desde allí se podría proteger "el valle de Bacanuchi, que es el real de minas y el más principal que tiene la provincia”, a catorce leguas de la Cananea, y los pueblos de Bacuachi, Chinapa y Arizpe, el real de San Antonio, el Monte Grande y real de Nacosari, "que ha sido el que más plata ha dado en esta provincia y hoy se halla sumamente atrasado y despoblado que han quedado como doce vecinos", por los ataques de los enemigos. Todavía debía proteger hacia el oriente el presidio el valle de Teuricachi y el de Santa María, y hacia el poniente las nuevas conversiones del Padre Kino y la frontera hasta El Pópulo de los seris, lo que hacía unas ciento sesenta leguas de circuito desde El Pópulo a

I78 Pardiñas a Quirós, Santo Tomás, 26 octubre I690. Ibid., fols. 438-440.

I 79 Castillo y los vecinos de Sonora al gobernador de Nueva Vizcaya. Huepac, 9 enero I69ז. Guadalajara, I54, pieza $3 .^{\mathrm{a}}$, fols. $78-84 \mathrm{v}$. 
Bavispe; y aún quedaba la línea de Bavispe-Guazavas-Bacadeguachi-Nacori y Serva, "que todos están fronterizos a los conchos que hoy están de guerra... y se han muerto de una y otra parte como cincuenta personas", con lo que el presidio tendría que cubrir alrededor de doscientas leguas. La junta pidió que tal guarnición tuviese unos efectivos de sesenta y cinco hombres y propuso como capitán a Andrés de Rezábal.

Seguramente no se había ordenado todavía la formación de este presidio. Se habían proporcionado solamente al capitán Ramírez de Salazar veinte soldados de Sinaloa y diez de los presidios de Cuencamé y Gallo que eran los menos hostilizados de Nueva Vizcaya. ${ }^{180}$ Ramírez salió a campaña con esta fuerza, que debió quedar constituida a fines de I69I, y parece que logró hábilmente atraerse a los sobaipuris dejándolos enemistados con los apaches, pero luego resolvió dividir su gente en cuatro escuadras que dejó apostadas en los sitios que juzgó oportunos y se dirigió a México para pedir refuerzos al virrey. Entonces fueron asaltados Nacosari, que quedó despoblado, y Santa María Basaraca. Entretanto, Ramirez había obtenido en México se dispusiese la formación de una compañía de cincuenta hombres sacándose veinte más de los presidios de Nueva Vizcaya, pero murió en Zacatecas, cuando volvía a su puesto. Entonces, el 28 de febrero de 1693 , nombró Galve capitán de la compañia de Sonora al exgobernador de Nuevo México don Domingo de Gironza. ${ }^{\text {I8r }}$

Los dos últimos años pasados se habían hecho otras tentativas para acabar con la belicosidad de las tribus apaches. En febrero de $169 \mathrm{I}$, los Padres Salvatierra y Loyola habían pedido desde Chinapa algunos indios mansos de El Paso que se suponía tenían autoridad sobre los janos y jocomes y serían eficaces embajadores de la paz deseada. El gobernador Vargas de Nuevo México envió al capitán Juan y otros cinco mansos, pero no parece

180 Los vecinos de Sonora al virrey, San Juan, 6 febrero r693. Guadalajara, I 51. I 8 I E1 conde de Galve a S. M., M'éxico, 6 enero I696, núm. 36. Guadalajara, I 5 I. 
que su misión tuviese éxito, puesto que la guerra continuó. ${ }^{182}$

E1 Ig de abril Juan Fernández de la Fuente propuso la unión de las armas de Nuevo México y Nueva Vizcaya en Janos para llevar a cabo una campaña decisiva contra los nómadas. Apoyado el proyecto por el fiscal de México don Benito de Novoa Salgado en julio, ${ }^{18} 3$ las tropas debieron concentrarse en Janos hacia el 20 de octubre, y Vargas y Fernández realizaron una entrada al Gila, la Pimería y Teuricachi. Fernández hizo nuevas campañas en I692, consiguiendo sólo breves respiros para los vecinos de Sonora. En I693, aunque Gironza fue nombrado capitán de la nueva compañía volante, la provincia estuvo bastante abandonada porque don Domingo debía empezar por reclutar sus hombres en Nueva Vizcaya; el virrey le acumuló en 2 de marzo la alcaldía mayor de Sonora, por renuncia del capitán Melchor Ruiz, y en el intervalo se dio el gobierno interino al capitán don Pedro García de Almazán. ${ }^{184}$ La crisis de Sonora era reflejo de la que afectaba a toda la frontera: el gobernador de Parral hacía sacar todos los soldados que allí había de Janos, Cuencamé y El Gallo para atender a las campañas de Nueva Vizcaya, y Fernández pedía veinticinco hombres más de Sinaloa al alcalde nuayor don Manuel de Agramont para poder combatir a los apaches. Agramont sólo envió dieciséis, que sumados a los catorce tiempo atrás destacados al mando de Antonio de Solís, y cincuenta auxiliares, se unieron a la fuerza de Fernández y dieron batalla a los apaches en diciembre de I693. El capitán de Janos, después de este reñido encuentro, decía que nunca había luchado con indios semejantes. ${ }^{185}$

Gironza, Mange y Fuensaldaña

A mitad de diciembre de 1693 llegó Gironza a Janos, trayendo

I 82 Guadalajara, I39, fols. I 2V.-I5.

I 83 Ibid. fols. I I-I 2 y $49 \mathrm{v} .-50$.

I 84 Juan Fernández de la Fuente a Marín. Casas Grandes, 22 setiembre I693. Testimonio de autos de la visita de Marín. Guadalajara, i 7 .

185 Fernández de la Fuente a Castillo, Janos, 3 diciembre 1693. Ibid. 
consigo la nueva compañía recién reclutada. Tin aquel presidio conferenció con Fernández de la Fuente sobre la manera de contintuar las operaciones. Gironza llevaba tres años de servicios en Indias, habiendo sido visitador de los presiclios de Barlovento en 1680, alcalde mayor de Mextitlan en i681-82, y gobernador y capitán general de Nuevo México por dos veces entre I683 y i6go. En este últino empleo se distinguió sujetando las repetidas stillevaciones de los indios que tienen lugar precisamente en estas fechas y se le recordarál siempre por la destrucción de Zía. Vuelto a México y gozando de la apobación y favor del rey que le hizo merced de un hábito de cualquiera de las tres Ordenes Militares, se le clestinó a la nneva compañía cle Sonora y a la alcaldía mayor de esta provincia. En México se le wuió su sobrino Mateo Mange, que había traido la cédula de agradeciniento del rey, y que a pesar. de su juventud y de carecer de experiencia militar fue nombrado alférez de la compañía volante. ${ }^{186}$

Inmediatamente después de llegada hizo la compañía dos salidas para rechazar a los conchos y jovas que invarlían Nacori y Bacadeguachi. Luego, del 6 de abril al 6 de junio de r 694 se hizo la primera campaña contra los apaches, jocomes y janos, a los que se hicieron veinte bajas entre nutuetos y presos. Calcula Mange ${ }^{\text {IS7 }}$ que hasta entonces habían sido robadas o destruidas más de cien mil cabezas de ganado mayor y caballacla en las estancias de Terrenate, Batepito, Janos y San Bernardino. Sinultáneamente, sin embargo, de acuellos primeros éxitos, con razón o sin ella se recelaba que los pimas eran aliados encubiertos de lo sapaches. Mange personifica esta actitud en el teniente de la compañía, Antonio de Solís, antiguo soldado en Nuevo México, que hizo algunos castigos en Tubutama y entre los sobaipuris, donde buscaba rastros de caballerías robadas. Sin embargo, todavía en setiembre de r694 se mantenían fieles los pimas y contribuyeron a defender Cuchuta

186 Mange, $212-214$.

I87 Ibirl. 227-22S. 
contra seiscientos apaches, ${ }^{x} 88$ y en noviembre Mange, a la cabeza de treinta y seis presidiales y doscientos pimas, recorrió las sierras del Pinar, Pitaracachi, Batepito y de las Espuelas, hasta llegar a unirse con Fernández que acudia desde Janos. Dos dias antes de que se realizara esta conjunción, su columna fue atacada en un cajón por más de setecientos apaches, jocomes y janos. Mange tuvo un muerto y quince heridos, "aunque a ellos se les mató poco más, metiéndose como ciegos por arcabuces y espadas”, y los españoles se deshicieron de sus adversarios con la estratagema de soltarles sesenta caballos que llevaban para la remuda. Cuando encontraron a Fernández en el río de Guadalupe volvieron por el cuerpo del soldado muerto, y ya no hallaron enemigos en el lugar. ${ }^{189}$

También en I695 las operaciones comenzaron en oriente con una entrada a la sierra de Baynopa, desde la que los conchos y jovas hostilizaban Nacori. Hechas diez muertes a los alzados, fueron algunos más condenados a mortero y los restantes devueltos a sus pueblos de Casas Grandes y otros de que procedían. ${ }^{90}$ En abril de 1695 se produce el levantamiento pima comenzado con la muerte del Padre Saeta, misionero de Caborca. Gironza y Mange acudieron inmediatamente con la compañia y sus auxiliares pimas y fieles seris. Podia suponerse que los alzados habían sido sólo los de Tubutama, Uquitoa, y otras rancherías, parientes de los castigados por Solís, el año antes, aunque los demás se habían alzado también, por miedo a las consecuencias de la revuelta. Gironza acordonó el país con guarniciones en Tubutama, Uquitoa, Cucurpe, Dolores y San Ignacio. Hechos los primeros castigos, se anunció la paz siempre que fuesen entregados los cabecillas de la sedición, pero Solís convirtió dicha entrega en una encerrona que costó la vida a cincuenta hombres en el paraje de El Tupo, después de lo cual toda la Pimería ardió en deseos de venganza, siendo quemada la misión de San Ignacio, y la situación se hizo

I 88 Ibid. 234 .

189 Ibid. $234-235$.

190 Ibid. 236. 
tan difícil que Gironza lubo de pedir auxilios al gobernador de Nueva Vizcaya, viniendo en su ayuda los generales Juan Fernández Retana y Domingo Terán. La acción de las tres compañías, talando las milpas de los alzados e imponiéndoles castigos, fue decisiva; mediando la intercesión de los jestutas, los pinas se rindieron, celebrándose las paces en la ciénaga de El Tupo el 30 de agosto. ${ }^{191}$

"Salieron de sus tierras a manadas, echándolos el hambre de su tierra a servir por sólo conter con los españoles de Sonora y Padres, con quienes hizo el Padre Marcos Kappus una imposible acequia para el conducto del agua de un molino". El siempre torpe estilo de Mange, plagado de pésimas concordancias, y que logra en la cita anterior uno de sus peores ejemplos, conserva aquí al menos el dramatismo de las primeras frases. Los cultivadores pimas altos poco tiempo podían resistir privados de sus cosechas, y correr y talar la tierra era táctica que los españoles sabían bien y habían practicado y sufrido ampliamente en los viejos tiempos de la Reconquista. Así, pues, la rebelión empezada en abril había sido acallada en setiembre, y aquel año fue, además, feliz en el frente apache : una batida en la Sierra de Chiricahui proporcionó el hallazgo del botín acumulado por los jocomes. Luego, una vez dominados los pimas, Gironza, Terán y Fernández, con las tropas de Sonora, Sinaloa y Janos, entraron hacia el Gila e hicieron sesenta muertos y setenta prisioneros a los apaches. La campaña fue muty dura: allí murió Terán, y los más de los soldados volvieron enfermos, ${ }^{192}$ Aunque parezca extraño, también I696 comenzó con una campaña de Antonio de Solís contra los conchos, cuyos agitadores y cabecillas se habían fugado de los morteros en que cumplían condena. Solís apeloteó a los tres más culpables y los demás quedaron sujetos para no alzarse más. Después tiene lugar un robo de ca-

I9I Ibid. 236-243. La información más directa sobre este levantamiento y su castigo se halla en Kino, Eusebio F.: Vida del P. Francisco J. Saeta, S. J. Editada por Ernest J. Burrus, S. J. México, Jus, I 961 .

192 Mange, 243-244. 
ballada por los janos, jocomes y apaches en la estancia de Tonibavi y la muerte de diez personas con el capitán Cristóbal de León en la Sierra de San Cristóbal: en la represalia, Gironza y Fernández unieron una vez más sus fuerzas y, persiguiendo a los agresores en la Sierra Florida y el Gila, les causaron treinta bajas y cincuenta prisioneros. 193 Se sabe que este año, además, al sublevarse la Tarahumara, se produjeron inquietudes entre los ópatas, como en la frontera de Tacupeto. Por tres veces huyeron a los montes indios de Cuquiarachi, Cuchuta y Tenricachi, hasta que el 8 de diciembre quedaron finalmente sosegados, no sin que Gironza hiciera ahorcar a cinco cabecillas en el real de San Juan. Don Pablo Quigue, gobernador de Santa María Basaraca, a quien se suponía principal motor de aquellas turbaciones, fue muerto por un rayo con otros cuatro indios a las puertas del presidio de Janos. ${ }^{194}$

En I697 tiene lugar el viaje para nosotros más interesante del Padre Kino: el que realiza con Mange y Cristóbal Martín Bernal por tierras de los sobaipuris hasta el Gila y en el que quedó de manifiesto que aquellos indios eran enemigos declarados de los apaches; como que al año siguiente, después que éstos incendiaron la misión de Cocospera - y sufrieron una seria derrota a manos de los presidiales y pimas en la retirada de esta acción - les infligieron $u n$ golpe serio, haciéndoles sesenta muertos que quedaron sobre el campo en Santa Cruz y Sahuaripa. Este encuentro tuvo según narra Mange una importancia decisiva sobre los enemigos de Sonora, porque "derrotado y quebrantado su orgullo, dividiéndose de los apaches, los janos fueron a dar paz al Paso del Nuevo México y contaron que los que fueron heridos del mortífero eficaz veneno de las flechas de los pimas habían muerto rabiando y eran en número de ciento sesenta y ocho, y así lo escribió el capitán Luis Granillo, con que se devastaron sus fuerzas". ${ }^{195}$ Después de

193 Ibid. $244-246$.

I 94 Escribanía, $390 \mathrm{~B}$, pieza $2^{\mathrm{a}}$, fols. I56-I59v.

195 Mange, 247-259. La expedición de Martín Bernal y la victoria sobre los apaches aparecen documentadas en Ocaranza, Fernando: Parva crónica de la Sierra Madre y las Pimerias. México, I942, págs. 31-55. 
esto, la actividad de los apaches contra Sonora decayó liasta casi desaparecer, fuera de algunos robos aislados. Por entonces precisamente se estudiaba en Madricl li propuesta del fiscal del Consejo para convertir en presidio en Teuricachi la hasta entonces compañía volante de Sonora, y la sugerencia del gobernador Pardinas, hecha en I693, para que pasase a establecerse en esta misma provincia, en el paraje de Los Cedros, el presidio de Sinaloa. ${ }^{196}$

La última intranquilidad de Sonora en este siglo vino por parte de los seris salineros que robaban en Tuape, Cucurpe y Magdalena. Gironza tuvo que enviar al alférez Juan Bautista Escalante con quince hombres a contenerlos. La campaña de Escalante contra los seris, en tres salidas, tuvo lugar de enero a abril de I70o y dio ocasión a una serie de escarmientos, persecuciones, reducciones a pueblo en Los Angeles o El Pópulo de algunos seris y retirada de otros a la vecina isla de Tiburón, que Kino llamaba de San Agustín. ${ }^{197}$

El 2 I de marzo de I YoI, en fin, Fuensaldaña tomaba posesión de la capitanía vitalicia de la compañía de Sonora, establecida en Santa Rosa de Corodeguachi, cargo que le había sido conferido por el rey en I699. Así se retiraba Gironza de la escena de Sonora, donde había consumido su esfuerzo durante más de siete años, y todas las provinciass costeras entraban en un nuevo siglo, de signo muy distinto para su historia. ros

I 96 Guadalajara, I 52 , fol. 6. Real orden de 3 julio 1698 , Guadalajara, I 52.

I97 Mauge, 28I.

198 Toma de posesión en Guadalajara, i 54. 


\section{IN DICE AN ALITICO}

A

Abreros, Juan Ignacio de: I 97.

Abuya, Santiago de: 45,56 .

Acachán: 4 бo.

Acajees, indins: 236, 237,259 .

Acalo: 106.

Acaponeta : $23,42,62,63,237,238,239$, 200.

Acapulco: $25,26,256,291$.

Aconchi: 70 .

Acuña, Andrés de: 197.

Acuña, Francisco de: 2 So.

Acuña, Lázaro de: 66.

Achiotla: 105.

Achires, indios: 29, 6r, $63,64,170$.

Adluana, paraje: I43, I 47 .

Agruas Calientes, paraje: 42.

Agueragrato: 36 .

Agnila, Vicente del, S. J.: 59.

Agtuilar, villa de: $257,258$.

Aguilar, Antonio de: 276,279 .

Aguilar, Diego: 149.

Aguilar Maldonado, Diego de: 17.

Aguirre, José de: I50-I 52.

Agramont, Manuel de: 92-103, I04, I40, I52, I53.159, 302, 304, 314.

Agramont y Arce, Cristóbal dé: i 52, I53, I 55 .

Agramont y Arce, Francisco de: III, I3I, 155-157, 265 .

A.grictultura: 12, I $3,21-22,55,60,170-$ ISo, 304 .

Aguacatlán: 107.

Ahome: 26, 29.

Ahomes, indios: 244.

Aibinos, indios: 248.

Alamo Hueco: 285 .

Alamos: 39,40 , II 2, I I 3, I 4 I, I 43, I 45,
I $47, \quad$ r 40, 260, 294, 297, 208, 302, 303, $305,307,308$.

Alarcón Fajatón, Diego de: I 35.

Alina: 56 .

Alberca, paraje: 207.

Albizil, Antonio: 276.

Alcabalas: i I I, iा 9 .

Alday, Martín de: 307 .

Alegre, Francisco Javier, S. J.: 5.

Aemanes: 183.

Aigarbes: 93 .

Algeciras : 93.

Alicanlac: $56,57,106$.

Almasro, Andrés de: 272.

Almendral: 26 .

Alvarez, Gaspar, alias "Curtimenta": 19, $23,27,53$.

Alvarez, Hernando: 54 .

Alvarez, Juan: 50 .

Alvarez de la Bandera, Francisco: I 21, 259,260 .

Alvalez Castrillón, Pedro: 66.

Alvear, Gaspar de: I 22, 237, 238, 239.

Alvarez' Serrano, Juan de: $18,27$.

Alzate, Jerónimo de: I72.

Amarilla, Diego cle: 143.

Amarilla, Juan: 197.

Amatlán: 146.

Amaya, Pedro de, vid. Maya.

Amaya Topete, Jesús: 5.

Anchieta, Juan de, S. J.: ISo.

Anguis, Juan Antonio de: 137, I 44, 286, 287 .

Angostura, paraje: 42 .

Animas, nina de las: 222.

Año, Gregorio /de: 277 .

Apaches, indios: $43,72,254,265,268$ $270,273,278,309,3$ I0, 3I2-3I9.

Aragón: 93. 
Arauda, Miguel dele: $38.39, S_{4}$, i $26,12 S$, I 35 .

Aranzana, Felipe de: 288.

Arivechi: 43, 71, 257, 292, 293, 295 . $297.299,305,308$.

Arizpe: $70,252,270,273,274,285$, 3I 2 .

Atizpe, intendencia de: 2.

Arteaga, Manuel de: 205, 208, 229.

Arregui, Domingo Lázaro de: 14, I 7 , IS, 24, 28, 29, 32, 45, 47, 48, 5 Y, $52,54,55,57,58,63,75$.

Arriaga Agüero, Alfonso: 157.

Arriería: 51, r72-174, 197, 233.

Arriola, Andrés de: $29 \mathrm{I}$.

Aspilueta, Martín de; S. J.: 59.

Atamura: $35,46,57 \cdot$.

Atondo y Antillón, Isidro de: 85-89, 9I, I05, I20, I34-140, I 44, 253, 261 , $262.265,274,281,286,287,309$.

Ayeta, Fr.,Francisco de: 265.

Atapascos, indios: 254, 275 .

Ategrialato: 46 .

Audiencia de Nueva Galicia: 6, 8, 17 , I $8,40,4 \mathrm{I}, 64,65,77,78,8 \mathrm{I}, 89$, $90,95,109$, II 2, II4, II9, I 28-132, I 38-152, I67-168, I70, $177-1 S_{4}$, IS5, IS6, 188-19I, 193, 20I-206, 209, 215 , $217,225,226,228,230,23 \mathrm{I}, 234$, 238 .

Alistria: 03.

Avilameto: 106.

Ayabuto: Io6.

Ayona: ro6.

Azogue: I7, I 8,4 I, I+I.

\section{B}

Babiácora: 70, 200.

Baca, Cristóbal: 283.

Bacadeguachi: $70,166,267,270-272$, $284,285,313,3$ I 5 .

Bacanora: 38, 292.

Baycanwchi: 691, Iг2, $210,277,278$, $310,312$.

Bacerac: vid. Basaraca.

Bacobichi: 268, 273-275.

Bactuachi : $70,166,252,266,269-27 \mathrm{I}$, 312.

Bactuachi, río de: $65,266$.
Bacubirito: I 76.

Bachnara, Diego: 232 .

Bachimeto: 56 .

Baducque, Francisco, inclio: $268,272$.

Bagueri, indio: 272 ,

Baibachilato, puerto de: 24,27 .

Baila: $57,58,105$.

Bamoa: 186,248 .

Banachare: 38, 215, 221 .

Banámichi: 70,252 .

Banasuri, Francisco, indio: $268,273$.

Bandelier, Adolph y Fanny R.: 48, 59, $238,249,260,200,310$.

Bancleras, valle de: $26 \mathrm{r}$.

Barcelón, Pedro: I85, 189, Igo, I9I, 224.

Barcelona: 93.

Barlovento: 315 .

Baromi, indio: 270 .

Barrabás, cerro de: 248 .

Barrasa, Mateo de: 34 , 108 .

Barreda, Pedro de: II9, 13I, I67.

Barrón, Juan Fernaudo: 50.

Basaracil, Santa María de: 70, 266, $267,270.272,276,279,280,282,284$, 285,3 I $, 313,318$.

Basaracas, indios: 252.

Basilio, Tomás, S. J.: 50.

Bristida, Pedro le la: $85,80,150$.

Basusa, indio: 268 .

Eatacuma, indio: $27 \mathrm{r}$.

Eatepito: 252, 286, 3I5, 3T6.

Batopilas: 307 .

Batuco: 70,285 .

Bavispe, río de: 43, 70, 253, 267, 282 .

Eavispe, San Miguel de: 70, 266-268, $270-273,279-285,3$ I I, 3І3.

Bavispes, indios: $43,252$.

Baynopa, sierra: 316 .

Bazán, Hernando de: 54.

Beltrán, Fr. Manuel: 276 .

Beltrán de Guzmán, Nıño: 4, I I, 12 , I $4,40,58,64,73,78,242$.

Berapa: 299 .

Berganza: 104.

Berkeley: 58 .

Bermejo de la Carrera, Felipe: I 20, 262.

Bernal de Huidobro, Manuel: 105.

Bernal de Pinadero, Bernardo: $26 \mathrm{r}$. 
Betancur, Matias de: 40.

Betencourt, Juan de: 200.

Eielles de Diluutas: $77, \$ 3$, II), I 33 , $156, \quad 135$.

Blanco: 65.

Bolson die Mimpini : 20 $0 \mathrm{~J}$.

Bonnineto Lorenzo, incio: 20 o.

Bergonia: 93.

Brobante: 23 .

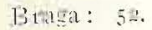

Euchatrini, indio: $27 \mathrm{r}$

Buelust, Fustaquio: 4.

Buellá, Andtés de: 65, I36, 261.

Prtenatista: $3+8$.

Puiza, Juan de: 1-19.

Butgueño, Pedro: to.

Butrus, linest J., S. J. : 317 .

Bustamante, Francisco de: 20, 2r, 251 .

Bustamante Bustilio, Bcrnardo: I53, $25 \mathrm{I}$.

Bustinza, Juan de: 40.

\section{C.}

Cabilios: \&, 95, I 09 , I 10, 1 $36-138$, I S6.

Caborca : 316 .

Caibreta, Miguel Antonio de: 102.

Cacaria: 237 .

Cadereita, marqués de, virrey de $N$. España: 19, 20, 22, 78, 25I.

Cadereita, presidio: 287.

Cádiz: $\mathbf{0} 03$.

Caiso, Juan, indio: $166,260,275$.

Cajas reales: $15,77,83$, I05, I OS, I I 1 , II3. 330 .

Calderón y Ojeda, Mistiel: $35,36,56$, 57, I09, 1 36. I67, 168, г76, 177, ISE, IS6, TSS, I Eg, I9I, $224,226$. 228,233 .

California: $9,18,23,25,26,27,81$, $85-87,01$, I 20, I 34, I 35, I 37, I 391 $\mathrm{I}+\mathrm{t} 0, \mathrm{I} 4 \mathrm{t}, 235,25 \mathrm{I}, 254.256,26 \mathrm{I}-263$, 286,287

Calvo, Juan, S. J.: 59.

Calzada, conde de la: yo3.

Camacho, Mateo: 49.

Camanaca : 56 .

Camoa: 40, I4I.

Cinmorlingo, Pedro de: 203, 2I9, 222.
Cimpa, Luis de la: 222.

Cincluea: $260,273,312$.

Conari, lucas, iudio: $268,270-272$.

Canaria: 93.

Canelas, Mateo, mestizo: 239.

Conito, inclio: 278 .

Canto, Alberto del: 53.

Canas, rio de las: I, 40, 74, I6I.

Canizares, Pedro de: 50.

Crpelo, Bernarto: 292, 206-29s, zoo, zor. Capirato, San Juan: 56 .

Carantapa, Santiago de: 16, 17, 56, $57,78$.

Carapon, presiclio de: $23,24,55$, I 76 , $225,244,248,250$.

Carbonell, Esteban: 27.

Cárdenas, Juan, S. J.: 59.

Cardona, Tomás de: 26 ,

Carichic: 300 .

Carlos, indio: 291.

Carrlos II: 85, 93, 287.

Carpio, Fermando del: 49.

Carretas: $163,265,267,268,273,276$, $277,279-28 \mathrm{I}, 284,285$.

Carrizal: 200.

Carrizal, paraje: 147, I 48.

Carrizal, áo del: 23.

Casa de la Contratación: I03, I 63.

Casas, Fr. Bartolomé de lás: I62.

Casas Grandes: $43,77,254,255,259$, $260,265,268,276,2 S 0-2 S_{2}, 284-286$, $310,312,314,3=6$.

Cásas Grandes, presidio: 43, I 48 .

Casas Grandes, rio: 43 .

Castañeda, Tuan Ignacio: 302.

Cástilla: 5I, 93, IS3, I0I, 25 I, 297.

Castillo, Antonio del: 27.

Cistillo, Blas del: 202-294, 3 II, 3 I 2.

Castillo, Gabriel del: I 20, 302, 303, 3 I 4 .

Castillo, José del: I97.

Castín, Pedro Juan, S. J.: 59.

Castro Sotomayor, Juan de: 288.

Cataluñล: 93, 155.

Cavendish, Thomas: 24.

Ceballos Villagutierre, Alonso de: $29 \mathrm{I}$, 302,307 .

Cedros: 3 I 9 .

Cepeda, Luis de: 49.

Cerdeña: 93.

Cerocaltui : 294. 
Cerra1bo, marqués de, virrey de $\mathrm{N}$. Es. paña: II 8, I $9,250$.

Cerro Gordo, presidio: I53.

Céspedes del Castillo, Guillermo: I54.

Cestin de Cañas, Luis: I33, 255.

Ceuta: 52.

Cibola: 40.

Clavero, Manuel: 292, 295, 296.

Coaguillona, sierra: 286 .

Coahuila: 4,277 .

Cobamei: $\mathbf{2 4 9}$.

Cocala: 57 , I 06 .

Cócorit: 246.

Cocospera: 3 IS.

Cogote: 57,58 , I 06 .

Colmo: 46 .

Colorado, río: I, 247, 3 I 0.

Comanito: 56 .

Comercio: 51, 55, 60, 67, I I 8-121, I69, I 72, I74, ISo, I99, 202, 2I5, 2I 7-223, $233,234,250$.

Companía volante de Sonora: 43,3 I 2 . 319.

Compostela : 107.

Comuripa: $7 \mathrm{I}, 248$.

Conchos, indios: 43, 72, 254, 268, 271, $276,28_{2}, 28_{3}, 286,307,3$ I 5-3 I 7 .

Conchos, presiclio: 153,307 .

Conchos, rio: 43 .

Conibuamea, Luis, indio: 232.

Conicarit: $40,14 \mathrm{I}$.

Conimeto: 56 .

Conitaca, San Juan: 56 .

Consejo de Indias: 8, 79, 80, 90, 91, 94, 96, 99, I $\mathrm{I}$, I 02 , I 09 , I I 4, I 30 , I 3 I, I 33 , I 45 , I 52 , I 58 , I 62 , I 80, I 82 , I $83,204,206,228,234,287,3$ I 9.

Consulado de México: I 49.

Contreras, Alonso de: 22.

Conversión : $28 \mathrm{I}$.

Copala: I, 2, 7, I4.I7, 38, 48, 49, 52, $63,74-76$, I 04, I 08, I I I, I $28,237$.

Coradepe: 299.

Coras, indios: 63 .

Córdoba: 93.

Corodeguachi: $309,310$.

Corodeguachi, presidio: 3 I9.

Coronado, vid. Vázquez de Coronado.

Cortés, Francisco: 152, I 53.

Coronado, José : 203.
Coronado, Juan: I 35 .

Coronado, Pedro: 292.

Cortés, Francisco, S. J.: 175-177, 179, Ig0.

Cortés, Hernán: 254.

Cortés, Jusée : 276 .

Correa, Jusepe: 53.

Corregidor, Juan Martín: 49.

Corrientes, cabo de: 23 .

Cosio, Antonio de: 305, 306.

Costa, Juan de: so.

Coto, Francisco: 214.

Coyotes: II $7,143,1+8,276$.

Croix, marqués de, virtey de N. Espaกิ1 : 4 .

Cruces, rio de las: 43

Cruz, Diego de la, S. J.: 59.

Cruz, Felipe de la: ins.

Cucurpe: $66,70,252,268,3$ I6, 3I9.

Cuchicague: 278 .

Cischina: 36.

Cuchuta: 70, 266, 273, 274, 278, 3 I5, 318.

Cuello die Fonseca, Gaspar: I47, I48.

Cuencamé, presidio: I53, 3I3, 3I4.

Cuervo, Francisco Javier, inclio: 279 , 280.

Cuervo de Valdés, Francisco Javier: 8 , 68, I I4-I I6, I I9.I30, I66, I67, 266, $27 \mathrm{I}-287,303$.

Cuevas, Mariano, S. J.: 5, I9, I I 8 .

Cuitacari: $27 \mathrm{~S}$.

Cuiteco: 294.

Culiacán: I-4, 6, 7, II, I3, I6.18, 23, $24,29,31,32,35,36,42,57,58,6 \mathrm{I}$, $73-79$, I05, I07, I09, III, II 2 , I 28 , I 52, I 55, I6I, I 67.168, 235, 242, 246, 254.

Culiacán, pueblo: 45, 56, 106.

Culiacán, río: 55 .

Culiacán, villa de San Miguel de: 3, I I-I4, I6-1 8, 25-27, 29, 37, 42, 43, $46,47,52,54.58,63,73$, I 05, г 06 , I 52, I 55,167, I $84,235,246,254$.

Cumpas: 70, 199, 217, 220, 270, 285. Cuquiarachi: $70,252,266,268-270,272$, $273,275,309,3$ I0, 3I8.

Curita, Lorenzo, indio: $166,167$.

Cusihuiriáchic: $43,260,296$. 
Cuspita: 106.

Giweo (Períi): 288.

\section{$\mathrm{CH}$}

Clagre (Panami): 488.

Chenela: 107.

Chotay: iz6.

Cliateas: $10 \%$.

Clarcas real ie 1as: $53,74$.

Clemo, Pedro indio: 333 .

Clievaliet, Fnamcois: 14. I64.

Chimula: I, 2, 7, 11, $12,14,75,10$, $23,-4,27,25, \quad 30-33,35,42,45,47$. $48,51,53,5,63,64,73 \cdot 75,106,108$, 100, I I , I 22,128, I $63-165.236$.

Chicoralo: 333 .

Clicoratos, indios: 246.

Chichinecas, indios: $32,34,164$.

Chilualuma: 37,44 .

Chile: z89.

Chilebito: 57, I06.

Chimaltitiun: $10 \%$.

Climat: $55,145,246$.

Chima, nisos de: 26,27 .

Chinap: $70,252,266,258-274,285$. $312,313$.

Chinatras, indios: $276,312$.

Clinipas: 244,240 , 200, 204, 200, 304 . 308.

Chinipas, indioz: 250, 250, 200.

Cluiricullui, sierta: $258,31 \%$.

Clirinos, Peraimender: 42,43 .

\section{D}

Dávila Pacheco, Enrique: 129, I 35.

Daza, Luis Antonio: IOI.

Decorme, Gerardo, S. J.: 5, 43, 70, 7 г, $243,246,247,250,252,253,262$.

Deza y Ulloa, Antonio de: 92.

Diablo, serra y peñol del: 28I, 282, $2 S_{5}$.

Diariacato: 46 .

Dialz, Alonso: I $32,240,242,243,254$, $256,286$.

Diaz, Diego: 234 .

Diaz de Ja Calle, Juan: So, In5, io6, $16_{3}$.
Dicastillo, aid. Jópez de Dicastillo.

Diputados del conlín: Iro.

Dolores, Ntra. Sia. de los: 376.

Dudagoitia, Simón de: 143.

Dunne, Peter Mrasten, S. T.: 5.

L.19ui, iadio: 272 .

Dutango: 5,6, I3, I5, I7, 19, 20, 20, 25, 3I, 39, +2 $43,48,54,63,73,76$, $77,80,8 \mathrm{I}, \S_{3}, 100-102$, I 08, I I I, II 4 , I $18,120,122$, I $32,135,162$, I 63, I 72 , $207,237,240,243,247,262,30.4$.

Durlian: 164.

\section{It}

Echevarria, Juan Antomio de: I97.

Echojoe: 304.

E! Fuclete: II 2, IS $_{7}$, ISS, $245,25 \mathrm{I}$.

Li Oro: 6r.

E! Psso: 43, 6S, 255, 259, 264, 265, $268,2 \div 6,284,313,3 \mathrm{IS}$

Ei Pópulo : 262, 3Т 2,3 Ig.

El Realejo: 25 .

El Tupo: 3]6, 317.

Li Valle: 296 .

Elota : $28,46,63$.

Eincinas, Juan de: 203, 20\%: 225, 227. 277.

Encomenderus: 51 .

Eirconicndas: $56,5 \%$, I 28, I $62-164$, I67I 68.

Iiscalante, Juan die: 310, 3II, 3 I9.

Escalera, Tuan Manuel de la: r.36.

Escandón, José de: I 2.

Escañtiela: 136 .

Esclavos: $64,65,164-167$.

Escorza, Juan Bautista: I66, 265-267. $270-272$.

Eseninapa: 45 .

Esprelas, sierra: 3 I6.

Estén, Juà 1u. de: 40.

Estéver, Domingo: I 49.

Estrada Ramírez, Bartolomé de: 76 . So.S2, S4, IIg, I 22, I 26, I 29, I 31 , I34-139, I 66, 262, 264, 265 .

Estrella, Juan Antonio de, S. J.: 206, $207,27 \mathrm{I}, 276,277,279,280,282$, 283.

Eurleves, iudios: $21 \mathrm{r}, 2 \mathrm{I} 2$.

Extranjeros: $52-53,54$, I 83 . 


\section{F}

Felipe II: 164 .

Felipe III: I6.17.

Femández, Baltasar: 52.

Fernández, Bernardo: 296-298, 30r.

Fernández, Juan: 50.

Fernández, Miguel : 49, 50.

Fernández, P.: 262.

Fernández de la Fuente, Juan: 277286, 3I0, 3II, 3I4, 3 I5, 3I8.

Fernández de Madrigal, Francisco: 76 .

Fernández de Morales, Juan: 133, 257 , 258.

Fernández de Retana, Juan: 303, 304, $306-308,317$.

Fernández de Somoza, Antonio: 102.

Figueroa, Gaspar de: 232.

Figueroa, Jerónimø, S. J.: 43, 252.

Filipinas: $24,246$.

Flandes: 93,155 .

Flores, Francisco: 232.

Flores de Sierra, Alvaro, S. J.: I 87.

Florida, sierra: 318 .

Fiorseca, Baltasar de: 49, 52.

Fontes de Espinosa, Gabriel: 1 $36-138$, 197.

Forbes, Jack D.: 254.

Frailes, Ntra. Sra. de la Concepción de los: vid. Alanos.

Franceses: $18_{3}$.

Franciscanos: 43, 68, 70,109, 252-254, $259,268,276$.

Francisco, indio: 291 .

Franco y de Luna, Alonso: 2r.

Franco Maldonado, Juan: i 94, 223-228.

Fresnillo: 107.

Fronteras, presidio: 43 .

Fuensaldaña, Jaciuto de: $40,112,152$ I 58 , I59, 302, 303, 308, 3ig.

Fuente, Gaspar de la: 107.

Fuerte, ría: 24, 29, 61, 244, 245, 248, 298.

Fuerteños, indios : 59 .

\section{G}

Gagn de Mendoza y Sotomayor, Car. los: 77, I 22, 259.

Gaica, Pedro de: 50.
Galarreta: 76 .

Ga1ga, La: 106.

Galicia: 93 .

Galve, conde, virrey de $N$. España: II 7,152 , I55, 158, 20I, 302, 3 I 2,3 I 3 .

Gálvez, José de: 2, 4

Gallegos C., José Ignacio: 48, I62.

Gallo, presidio del: 3 J 3,3 I 4 .

Ganadería: I2, IS-2 I, I69, I72, I 73, I $99,205,208,292-293$.

Garcia, Alonso: 2SI.

García, Bartolonlé: I 40.

Giircia de Almazám, Pedro: 282, 285 , 3 I 4 .

García de Dicastillo y Azcona, Blas: 76 .

Garcia de Salcedo, José: $76, \quad$ 2 29: 131 , I $36,204 \cdot 206,228,229$.

García de Terán: 278 .

García Valdés, Juan: i i 9.

Gascón de Prado, Laureano: 214, 224.

Gastegui, Antonio de: $137,138$.

Génovia: 52, 53.

Genovés, Alejandro: 52 ,

Gentiles, real de los: 38,76 ,

Gibraltar : 93.

Gila, río: 40,68, 72, 314, 317, 318 .

Gillert, Cornelio, S. J.: 66.

Gironza y Petriz de Cruzat, Domingo de: $8 \mathrm{I}, 166,304,313-319$.

Gómez, Bernardo: 163 .

Gónez, José: I $\$_{5}$.

Gónez, Mis̆ruel, S. J,: 59.

González, Antonio: 229, 231 .

González, Ignacio: 223.

González de Barriga, Alonso: 256.

González Rodero, Andrés: 168, is 4 .

Gorráez y Beaumont, Francisco: I 29, I 36, I 63 .

Goyeneche, Juan Francisco: 230.

Granada: 93.

Grande del Norte, río: $12,43,68,285$, 286.

Grande de Santa Cruz, río: vid. Santa Cruz.

Granillo, Luis: 3 I 8.

Grijalva, Juan de: 54 .

Grijalva, Juan: I95.

Guachimeto: 46, 63 .

Guachinango: 107 . 
Givelinera, San Juan: 70, 266-268, 270 . $272, \quad 97,279,282, \quad 285,313$.

Guadalajara: $5,6,0,14,16,15,25,35$, $38,49,4 \mathrm{x}, 58,60,64,73,56-8 \mathrm{x}, 80$. $9 \mathrm{I}, 95,104,106,107,115,112, \mathrm{II}_{4}$, $110,130-132,138,130,144,146,147$, $150-152,163,165.167,170,172,174$, I77, 180, I88-ror, 201, 203, 204, 209. $228,230,23 \mathrm{~T}, 234,238,240,20 \mathrm{r}, 322$, 307.

Guadildizan, marqués de, virrey de Nueva Figluna: $26,25,245,246$.

Guadalupe, rio: 316.

Guadalupe de Fil Paso: 68, 255.

Gradalupe de Paredes, real de Nitra. Sra. de: 40, II3, I I 7, I 20, I39, I41152,287 .

Guadiana: wid. Durango.

Guadianeche, Juan Francisen: 202, $293,225,301$.

Guagrasat: $205,200$.

Guajarlo Fajardo. Diego: 3\&, 133-1,35. $250,255-258,260$.

Guanuchiles: เоб.

Sulnacevi: 30,243 .

Gutenipa: $56,57$.

Giratometo: тоб.

Gunyahal: $13,24,26,20,64$.

Guazapares: 294.

Guazapares, inclios: $250,200$.

Guazavas: 70, 197, 218, 252, 270, 272, $277,270,282,285,313$.

Guazave: $186,187,226$.

Guazaves, indios: $243,253,254$.

Guebavi: 260 .

Gllepari: 284.

Guerra de Resa, Juan: 30.

Gitllén, Lotenzo: 49.

Gitrola: 35 .

Gutiérrez, Bernabé Francisco, S. J.: I $S_{7}$, I $89,101,193,194$.

Gutiérrez, Juan: 49.

Guzmán, Diego de, S. J.: 50.

Cuzmán y Córcloba, Blas de: 14 I, I 43 , 145, $147,148,150,15 \mathrm{I}$.

Gurmatillo: 42, 46, 73, 106 .

\section{$\mathrm{H}$}

Habsburgo: 93.

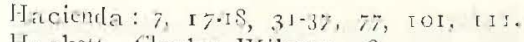

Hacket, Charles Wilson: 48 .

Haro y Monterroso, Fernando de: 64,

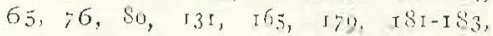
r $91,203,216,227: 234,240$.

Hatres, jidios: 307 .

Haros, rio de: 295, 305. 3Tu.

Hirredia, José G.: 5 .

Hermosillo: $2+7$.

Herróndez, Ba1tasar: 49.

Hertín, Simón Franciser de la: $8 z$.

Herrera Carrillo, Pablo: 6, 37, 172.

Hignera, Nicolás de la: $303.305,310$.

Hiluruto: 46 .

IIinceris, indios: 253,254 .

Holandeses: 27.

Hoyo, Juan del: 144.

Hoyo y Santayana, Domingo del: 197, $198,200,202.204,207,224,250$.

Huepaca : $70,312$.

Huidobro: vid. Bernal de Huidobro.

Humaya, río: $35,37,55,62,63$.

Hurdaide: aid. Martinez de Hurdaide.

Hurtado de Castilla, Pedro Alfonso: ז $35, \quad 136$.

Hurtado de Mendoza, Juan: I 43 .

\section{I}

J)arta, Diego dê: 42,236 .

Iharra, Francisco dle: 4, I 1, I $2,24,40$, $12,43,53,54,64,79,79, \quad 163,164$, 235,245 .

hharra, Pedro de: 19\%.

Ibarra Guinea, Cristóbal de: zio.

Iglesias, Francisco de: 8 I-S4, I I 4, I I 9 , I 29, 130 .

Iguana: 105.

Ilarito: 57 , ro6.

Ilarregui Pollerena, Gatcía de: 143.

Ilimaca : 46.

Ijotepeque: 210, 215.

Imala. 46,56 .

Indios: I $5,20-22,2 \$, 29,32-34,40$, $42,43,45 \cdot 47,5$ I $, 53-67,74,82-83$. 9o, 96, го6, I I0-II3, I I5-IIS, I 20 , I $23-126$, I 28, I 38, I 55.157, I $61-235$, $2+2,245,259,260,265-319$.

Inelios de sello: I $8,279,282,292-293$, $297,300$. 
Ingleses: 183 .

Isla, Juan de : 240

Itagi o Itlage: 46 , 106 .

Italianos: 183.

Iturbe, Juan de: $26,27,246$.

\section{J}

Jacobito: 56 .

Jaén: 93.

János, indios: $43,254,265,266,269$, $270,276,278,285,309-313,315,316$, 318.

Janos, presidio: 43, 2So, 294, 310, 311, 314-3 I 8.

Janos, río de: 285 .

Jauri, Javier, indio: 266, 269, 270.

Jerez: 107.

Jerusalén : 93 .

Jestritas : 4, I 2, 19-22, 29, 43, 53, 58-60, $66,69,109,161,168-236,240,242$, $245,249-253,258,262,269,274,282$, 30I, 310, 317.

Jifo: 105 .

Jijimes, indios: 236, 237, 259.

Jiménez Paniagua, Fernando: 80.

Jocomes, indios: $254,266,273,275,276$, $278,282,309-313,315-318$.

Jocopillo : 248 .

Jocotlán : 107.

Jojoi, Ignacio, indio: $268-270,272$.

Jornero, Agustín: 146.

Jovas, indios: $71,253,270,315,316$.

Juan, indio: $3 \mathrm{I} 3$.

Juan Bautista, indio: $179,180,190$.

Juan Francisco, indio: 176.

Juárez, Bartolomé : 26, 246.

Juárez, Martín: i 80.

Junari, Jerónimo, indio: 272, 274.

Jumari, Pablo, indio: 293, 295, 296, 299, $301,305$.

Jura, indio: 272.

Juraque, Juan, indio: 272,274 .

\section{$\mathrm{K}$}

Kappus, Marcos, S. J.: 317.

Kelly, Isabel : 58 .

Kino, Eusebio Francisco, S. J.: 5, 3 го, 312, 317-319.
L

Lagasca, Renier de: 102.

Lagos: 107.

Laguaruto: 56.

La Paz (Alto Perú): $28 \mathrm{~S}$.

La Paz (Califorvia): 255, 286.

Larrea, Juan de : 30 S.

Larrea, Juan Bautista de: I 53.

Laso Cordero, Juan: $232,233$.

Lasso de la Vega, Simón: I 34, 256-25 S.

L?ura, Marcos de: 50 .

Lázaro de San Millán, Francisco de: 103.

Leal, Antonio, S. J.: 273, 277, 282.

Lemos, conde de, virrey del Perú: I42, I 49 .

León: 93, 183.

León, Cristóbal, de: 285, 318.

León, Francisco de: 232, 233.

León, Manuel Francisco de: I 35 .

Lima : $154,258$.

Liserino, Francisco, S. J.: 232 .

Lombardo, Nata1, S. J.: 294, 296-299, 307,308 .

López, Andrés: 50.

López de Dicastillo, y Aramburı, Gre. gorio: $65.67,170,195-223,228,233$. 255.

López de Gracia, Andrés: 259, 265 , 267.

López de Sepúlvera, Francisco: 49.

López de Velasco, Diego: 50.

Lápez de Velasco, Francisco: 49, 52.

López de Vicuña, Juan: I7-I 9, 22-25, 27, 29, 3I $35,53,108,250,25 \mathrm{I}$.

López de Viera, Francisco: 49, 52.

Lorenzo, Tomás Autonio, vid. Paredes, conde de.

Loreto: 294.

Los Angeles: 3 I9.

Loto: 106.

Loyola, S. J.: 313.

Lucenilla, Francisco de: 138, 261.262. Lugo, José: 187.

Luque, Francisco de: I36, I75-I79, I81, I $84,185,180-19$ I, 193, 21 $2,227,229-$ $231,233,234$. 
LL

Llanes, Francisco de: 54.

L.1anes, Pedro Martin de: so.

I.1arin, Aberto, S. J.: 50.

Lierena : 107 .

\section{M}

Macoyalıti : 300 .

Madrid : 17, ab, 51,70, 22, 102, 103. $154, \quad 256,310$.

Magtalent: 310 .

Magdalen, rio de Ja: 253.

Malbeat, indio: 272 .

Malicohat: $7 \mathrm{~J}, 292,206,200,300,305$.

Maldonado, Diego: 5 n.

Maloya : 14-16, I8, 30, 4850, 63, 74$76,128$.

Malzura: $7 \mathrm{I}$.

Mallorca: 93 .

Manche, Lorenzo, indio: 274.

Mange, Mateo: 68, 252, 255, 310, 314. 319.

Manila: 256 .

Mansos, indios: 254, 276, 278, 3 ×3.

Manso, Fi. Tomás: 25 ?

Mara, Pablo, indio: $260,252$.

Mráin, Jozé Francisco: 314.

Marqués, puerto del: $23,24,20$.

Márquez, Crispín: 4.

Martín, Diego: 54.

Martin, Diego: ISo.

Wartín Bernal, Cristóbal: 3I8.

Martin Bemal, Juan: 205, 207.

Martínez, S. J.: 250 .

Martínez Hidalgo, Lutis: i 39.

Martinez de Hurlaide, Diego: 26, 27, I 05 , I I 2, I 32, I $35,240,24 \mathrm{I}, 243-249$, $254,261,286$.

Martinez de Mendíbil, Pedro: 294, 298.

Marraco, Gaspar: 53.

Marras, Daniel Angelo, S. J.: I 70 , 196204, 207.21I, 213, 214, 217-224, 229.

Matape: $198,203,204,208,209,213$, $214,218-220,222-224,233,248$.

Matape, río: 247.

Matequi, indio: 270.

Mataraichi : $205,206,209$.

Mataro: $15,16,46,74$.
Maya. Pedro de: $280,185,186,188-$ ID $1,228$.

Mayo, rio: $19,38,40,54,61,76,141$, $225.245,246,294,298,302304$.

Mayos, indios: $60,6 \mathrm{x}, 245,247$.

Mazapil: $107,239,243$.

Mazatlin: $23,28,30,31,45,47,74-70$, ros.

Mecham, Lloyd T.: 164.

Media mata: $84,92,104,503$, Is

Melins: 20 .

Nedrang, Gregorio: 35.

Nena Castilio, José: 4.

Ménde: Pedro, S. J.: 50.

Mesdoza, Cristóbal de: $23.32,233$.

Mendoza, Francisco de: 3or.

Mendo\%, J11an de: 65, I66.

Menceses, Juan de: 298 .

Mesa, Agustin de: 36 , I 30 .

Nesa, Bartoloné de: $33,108$.

Mestizus: 50, 66, I 43, I0I, 220, 239. 283,300 .

Mexía de Prarlo, Bartolomé: 48.

México: 7, 13, 18.20, 26, 27, 31, 34, 37, $43,5 \mathrm{I}, 50,62,85,9 \mathrm{I}, 92,104$, II 4 . II 7, IIS, I34, I49, $15 \mathrm{r}, 154,158$, $162,164,165,172,174,203,205$, $213,221-223,220,-30,234,236,237$, $243,244,250,252,-256,258,260,264$. $287,280,200,301,308,313-315,31 \%$, 318.

México, republica de: 2 .

Mextitlán: 315.

Miguel, Domingo: 297-299, 302.

Milín : 93.

Minas Nuevas, vid. San Diego de Minas Nuevas.

Mineria: $14-18,29,30,34-40,49,53$, $55,60-61,62,67,74,75,115$, I 3 , I22, I23, I4I, I42, 165, I 68-169, I 7 , I $75,195,214,215,237,248,260,300$, 309,312 .

Misiones: 3, 5, I2, 20, 2I, 42, 43, 44. $47,54,59,6 \mathrm{I}, 63,64,65,68,69-7 \mathrm{I}$, I 09 , II7, I6r, I $68.234,235,240,244$, $245,247,248,250,252,254,255,258$, $250,261,262,268,273,274,276,279$, $282,28_{4}, 290,303,311$.

Mobas: 71, 257, 208.

Mocorito: II $2,178,239,243$. 
Mocorito, río: $73,76,249$.

Mocoritos, indios: $177,181,183$.

Moctezuma, río: 70 .

Mochicahui : 244-

Molina, Agustín de: r 20.

Molina, La : 93.

Mojolo: 56 .

Monclova, conde de la, virrey de N. España: I 49-1 5 I, I54-I56.

Montaño de la Cueva, Francisco: 238, 239.

Montegrande: Iо7.

Monte Grande: 312.

Monterrey, conde de, virrey de N. Esparña: 3 I $236,237,239,243,244$.

Montesclaros, marqués de, virrey de $N$. España: 4.

Montesclaros, presidio: 245, 248, 287; vid. El Fuerte.

Montoya, Francisco de : 92.

Montoya, Pedro de: 236.

Morales, Luis de: I I2, 121, 280.

Morales Pastrana, Antonio de: 92, I04.

Moreno, Fieliciano Bernabé: IIg.

Moreno, Salvador: 272, 279, 284.

Moreyra Paz Soldán, Manuel: I54.

Moris: 296, 300, 303, 305, 308.

Mото el Viejo: 46.

Morones: 164.

Mortero, vid. Obrajes.

Mota y Escobar, Alonso de: 13-16, I 8, I $9,28,29,3$ I $35,37,42,45,47$, $48,51,54,55,57,63,64,239,242$.

Mototicachi : 278,3 10.

Muiderrama : 296, 299.

Mulas, isla de: $23,29$.

Mulatos: $28,47,74,117,143,147,148$, I 9.5, 2 I $3,224,283,285$.

Mulatos, río de: 299.

Munguía, Juan de: 215.

Muñoz de Pro, Bartolomé: 54.

Murcia: 93.

Murirato: 56,57 .

\section{$\mathrm{N}$}

Nacameri : 70

Nacatobori: 69, 1.12, 272, 277, 29:3, 301.

Nacori : $70,266,279,285,293,313,315$, 316.
Nacosari, Nra. Sra. del Rosario de: I I2, I 20, I $66,266,270,273,274,277 \cdot 279$, $283,284,3$ I0, 3 I 2,3 I 3 .

Naipes: IIr.

Nakayama, Antonio: 5.

Namiquipa, rio: 43 .

Napo: 273 .

Narriondo, Francisco: 288.

Natoato: 37.

Natora: 306,308 .

Natoras, indios: 307 .

Navarra : 93 .

Navegación: 23-27.

Navito: $28,32,35,46,56,106$.

Navolato: 45,56 , I 06 .

Nayarit: 62, 237.

Nebomes, indios: $70-7 \mathrm{r}, 247-249$.

Necaveva, indio: 243

Necuas, indios: $269,275,278$.

Negros: 15, 17, 213, 283.

Neira, José dé : 294.

Nío: $137,138,186,264$.

Niza, Marcos de: 40.

Nómadas: 47,6 I-67.

Novoa Salgado, Benito de: I I7, I56, 3 I 4 .

Nuestra Señora, puerto de : 23.

Nueva Andalucía, vid. Sonora.

Nueva España: 2, 4, I9, 28, 30, 3I, 37, 4I, $5 \mathrm{I}$.

Nueva Galicia: 6, 7, 1 3, 14, 16, 23, 25, $28,30-32,40,5 \mathrm{I}, 55,58,65,73,77-$ 79 , 106, 107, 129, I $51,16 \mathrm{I}, 162,167$, I $81,193,20 \mathrm{I}, 238,243,29 \mathrm{I}$.

Nueva Vizcaya: 4, 6.9, I3, 16, 28, 31, $32,34,39,42,43,47,48,5$ I-53, 59, $68,73-75,77-82,87,88,93$, 102-104, I08, I 09, III, II4, II 8 , II9, I 21 , I 28-1 30, I 32, I 34, I 39, I40, I 53-1 56, I61-167, 175, 177, І 81,182, I 86, I89, I9I-I93, 204, 206, 2I I, 228, 229, 23I, $236,239,240,243,246,249,250,257$, $259,260,263-265,276,29 \mathrm{I}, 302,3 \mathrm{II} \cdot$ 3I4, 317.

Nuevo Leán: I 3, 277.

Nuevo México: $4,29,43,48,67,68$, 104-I05, I 38, I 63, I65, I66, 252, 259, $264,265,267,268,273,274,277,28 \mathrm{I}$, $285,303,304,309,313-315,318$.

Nuevo Santander: I 2.

Núñez Cabera de Vaca, Alvar: 40. 
Núñez Morquecho, Diego: 79, 80, г3

Nuris : 7I, 257, 294, 298.300.

Obispo: $5,20-22$, 11 $6,172,207,230$, 304 .

(1)ispo, paraje del: 42.

Olirajes: I66, ISI, I $82,317$.

Obregón, Baltasar de: $19,53,64,163$, 164 .

Ocaranza, Fernando: 7,318 .

Oca Sarmiento, Antonio de: 74-76, 79, $104,108,128,136,175,176,259-26 \mathrm{i}$.

Cccidente, estado de: 2.

Ojeda, Mantuel de: $23 \mathrm{I}$.

Ojitos Fríos: 285.

Ojo del Perro: 28I

Olea, Héctor R. : 6.

Oliñano, Francisco, S. J.: 59 .

Otiapa: 71, 293, 295, 296, 299, 305, 307 ,

Onavas: $7 \mathrm{r}, 257,295$.

Oñate, Juan de: 68.

Opatas, indios: 6r, 69-72, 247, 252-254, $265 \cdot 275,278,280,283,284,303,304$, $310,311,318$.

Opatería: $69,247,267$.

Opodepe: 70, I 12.

Oporto: 52,53 .

Oposura: 70, 199, 217, 220, 282, 285.

Oputo: 70, 252, 254, 279.

Orozco, Francisco de: 50.

Ortega, Francisco de: 27.

Ortiz, Diego: 33, 50.

Ortiz de Otálora, Antonio: 102.

Osobampo: 148 .

Ostimuri: $1,2,7,38,43,69,71,76$, 77, 8I-84, 108, II0, II2, II4, II9, I $21-123,126,127,129,134,161,175$, $203,216,234,255,260,29$ I-302, 303, $305,308,3$ II.

Cistimuri, real de San Ignacio de: 38 , $76,82,260,295,296,299,300$.

Ostotipac: 107.

Oten, Guillermo, S. J.: 59.

Otermin, Antonio de: 67, 104, 176, 265.

Oxea de Bóveda, Domingo: 153.
Pablo, inclio: 311.

Pablo, Juan: 54.

Dacajes, inclios: 55 .

Pacheco, Francisco: $2 \Omega_{5}$.

Pacheco Celuallos, Francisco: 310.

Pacheco de Solís, Juan: I93, I94.

Palafox, Juan de, prelaclo-virrey de Ni. España: 252 .

Palmito, isla : 20 I.

Palomares Castro, Aulrés de: 230.

Panamá : 25, 288.

Panicagtii : 278 .

Pánuco: 15, 16, 30, 46, 52, 63, 74, 75.

Pápagos, indios: 72 .

Papasquiaro, vid. Santiago Papasquiaro.

Papel sellado: i r .

Papigochi: $290,302$.

Paraguay: 183.

Pardiñas Villar de Francos, Isidro cle: 291-294, 296, 298-303, 310-312, 319.

Paredes, conde de, marqués de la Laguna, virrey de N. España: 85, 9I, T04, I $38,150,240,287-290$.

Paredes, Blas de, S. J.: 59.

Paredes, real de; wid. Guadalupe de $\mathrm{Pa}$. redes.

Pareja: 157.

Paris: I64.

Parral, San José del: 6, 30, 37-39, 4244,6 I, 73, 78, 8I, 84,87 , I I I, I 2 I, I 22 , I 26, I 28, I 32, I $34^{-1} 37$, г 39, г 56 , I $63,165,166,172,174,178,182,205$, $206,216,224,252,254-256,258-260$, $262,264,265,276,284,296,302,303$, 3 I4.

Parras, Sta. María de las: I7, 32, 52.

Pasachi, indio: 275.

Pascual, mulato: 213 .

Pascual, Julio, S. J.: 250.

Patiño, Leandro, S. J.: 59.

Paz, Domingo de: 232, 295.

Pechelingues: $26,246,291$; vid. Piratas.

Pedro, indio: 295.

Pedro, indio: 257.

Penas de cámara: I00, I I3, II6, I 35 , I 67.

Peina, Melchor de la: 223 .

Peñaranda, Andirés de: I 02. 
Peñol Blanco: 29.

Peralta, Juan de: $133,253,256$.

Peralta, Pedro de: $266,26 \%$.

Peralta, Tomás de: $143,146$.

Perálvarez: 26.

Perea, Pedro de: 27, 37, 43, 67, 68, $70,76,7 \mathrm{~S}, 79, \quad 108, \quad 132, \quad$ I 35,204, $248-255,26 \mathrm{I}$.

Pereyra, Matías: $136,207,219$.

Pereyra Lobo, Natías: 207.

Pérez de Barreda, Pedro: 115.

Pérez de Domica, Juan: 40.

Pérez Granillo: 68.

Pérez Lora, Juan: 275 .

Pérez de Ribas, Andrés: 5, 26, 42, 55, 59-6I, I32, 214, 240, 242.252.

Perlas, pesquerías de: $23,25-28,53,255$.

Perú: I 49, 288.

Pesca: 23, 28-29, 51, 64.

Pescadero, El : 106.

Péscadores, Los: iob.

Petatlán, río de: 23, 6r, т $86,225,244$, 246.

Piaxtla: $30,32,57,74,75,108$.

Piaxtla, río: 55,62 .

Picondo, Pascutal: 282 .

Pie de la Cuesta, paraje: 42.

Pilares: 299.

Pimas, indios: 70-72, 247, 248, 252, 253, $268,28_{3}, 285,292,294,295,297-300$, $302,304,306,307,309,310,312$, $315 \cdot 318$.

Pimería: 69, 293, 310, 314, 316, 318.

Pinar, sierra : 316 .

Pineli, Litis Miaria, S. J. : 306.

Piratas: 24-26, I42, I57, 235, 246, 255, 286, 290, 29I, 302.

Pistoya, J. Jerónimo de, S. J.: 304.

Pita de 1a Torre, Alfonso: 74, 75, 104.

Pitaracachi, sierra: 316 .

Pitic: 247 .

Pizarro Cortés, Tomás: 179.

Plaza, Pedro de: 106.

Plomosas: 18.

Población: I I-I3, I 5 .

Poblezuelo: 45 .

Pólvora : I I I.

Poncitlán : Io7.

Porter Casanate, Pedro: I04, I33, I34, $250,253,254-258$.
Portillo, Alvaro del: 256,258 .

Portugueses: $23,43,52.53$.

Pótam: i 2.

Potlapiguas, inclios: 252.

Potosí (Perí): I4I, 288.

Prado, Nicolás de: 294 .

Presidios: 20, 22, 85, 93, 105, 153, 235-3I5.

Provincias Inter11as: 4.

Fuebla de los Angeles: 59.

Pueblo, indios: 68, $138,166,264,265$, 268.

Puno (Perúi): I42.

\section{Q}

Quesada, Isidro de: 292.

Quesada y Hurtado de Mendoza, Gaspar de : 230 .

Quiburi: $268,269,278$.

Quigte, Francisco, indio: $166,269,270$, 275.

Quigue, Pablo, in dio: $270,3 \mathrm{I} 8$.

Quilá: 46, 56 .

Quilitlán: I07.

Quintero, F. L. : 6.

Quintero, Lorenzo: 266, 272.

Quintero, Lucas: 266.

Quintos de oro y plata: 11 I.

Quirós, Andrés Bernardo de: 155.

Quirós, Diego de: I04, I16, II7, I39, I 40, I53-159, 29I-302, 306, 3Іт, 3І 2 .

Quirós, Juan Bernardo de: 49.

R

Rabelo, José: $3 \mathrm{Ir}$.

Ramírez Cabañas, Joaquín: I3.

Ramírez de Castro, Mateo: 175-177, I8I, 183.

Ramírez de Prado, Alonso: 230.

Ramírez de Salazar, Francisco: 276, 279-28I, 284-286, 312, 3I 3 .

Ramos, Francisco: 295.

Ramos, José, mestizo: 270, 271.

Ramos, Nicolás: 65, 66, 166 .

Rascón, Alonso: 166.

Ráum: 172.

Rebeico: 70.

Rebollar, Martín de: I31. 
Repartimientos de indies: 113, × $106.1 \times 8$, 1 62, 164, $179-182$, $1850-188$, I 03.195 , 215 .

Residencia, juicio de: $113-121$, I 20.13 I, I 35 .

Retana, vid. Fernández de Retana, Juan. Rezábal, Andrés de: $8,111,112,114$, $13 x, 158,159,285,302-308,3 \times 3$.

Rincón de Zamora: $63,238,239$.

Rio de la Loza, Rodrigo del : 13, 15, 31, $33,165$.

Rios Parral, Juan: 50.

Robles, Pedro de: 26, 54

Rochas: $210,222$.

Roclero, José: r 49.

Roclrígliez, Cristóbal: $5^{0}$.

Rodriguez, Diego: 54.

Rodriguez, Fernando: 50.

Rodriguez, Francisco: 50, 53.

Rodríguez Bayón, Francisco: 50, $23 \%$.

Rojas, Alonso de: 22.

Rojas, Autonio de: 92 .

Rojo de Briones, José: 148 .

Romo, Jusé : 67.

Tromo de Vivar, José : 137, 138, 207, 274,275 .

Rosal y Rios, Nicolás del: 92 .

Rosario: 38, 75,76, I о 8 , IIо, I52, 291.

Rubio Félix, Antonio: 48 .

Ruiz, Antón: 54 .

Ruiz, Melchor: 152, I53, 314.

Ruiz de Aguirre, Martín: 50.

Fiviz Cintado, Alonso: I43-I49, I 5 I.

Riviz Limón, Mateo: 310.

Ruiz de Olvern, Rodrigo: 49.

\section{S}

Sálenz de Carrizosn, Francisco: I42, I48. I 49.

Sacta, Francisco, S. J.: 5, 316, 31 7 .

Saguari, Juan, indio: $166,167$.

Sahuaripa: 43,71 , II2, 231, 233, 257, $284,292,293,295 \cdot 297,299,302,305$, 318.

Salizar, Tomás de: 102.

Salinas: $23,29-37,47,5 \mathrm{r}, 63,64,74$, 75, 10S, 109, III, I4I, I68, 233.

Salinas, valle de las: 29 .

Saltillo: 53 .
Salvatierra, conde de, virrey de N. España : $133,252,253,255,256$.

Salvatierra, Juan Maria, S. J.: 290, 29t, 294, 298, 299, 301, 3×3.

San Agustin, isla, vid. Tiburón.

Samalona: 46 .

San Andrés de la Sierra: 17, 30.

San Antonio: 112, 312.

San Antonio, presidio: 237 .

"San Antonio Nuevo", fragata: 26.

San Bartolomé: $14,75$.

San Bernardino: $3 \times 5$.

San Bruno: 287 .

San Cristóbal, sierra: 318 .

Sánchez, Cristóbal: 50.

Sánchez, Diego: 50.

Sánchez, Manuel, S. J.: 292, 295, 296.

Sánchez Mexía de Prado, Bartolomé: 49.

San Diego de Minas Nuevas: 61, 260.

San Francisco del Yaqui : 38 .

San Hipólito, presidio: 26, 237, 239. 246.

San Ignacio: 3í́.

San Ignacio, puerto dè : $23,24,26$.

San Ignacio, real de: I 7 .

San Ildefonso: $38,123,23 \mathrm{r}, 232,234$.

San Isidro: 287 .

San Javier: 70 .

Sa11 José, isla: 255.

San José, Fr, Juan de: 25 ?.

"San José", fragata: 286.

San Juan: 16.

San Juan Bautista de Sonora: 38,43 , $44,67,69,112,119,122,123,167$, $195.198,203,204,206,207,213,220$, $221,224,225,265-267,270-274,277$, $28 \mathrm{x}, 283.286,3^{1} 3,3^{18}$.

San Juan de Carapoa: 1, 2, 236, 244, 245.

San Juan de Ulúa: 289 .

San Lázaro: 176 .

San Marcial: 15.

San Marcial: i 2 .

San Marcos: 38,76 .

San Martin: 43,53 .

San Martin y Vértiz, Juan de: ra8.

San Miguel, rio: $70,247,262$.

San Miguel: $38,69,112,120,123,170$, $176,195-201,203,219,220,222-225$, $277,281,284$. 
San Nicolás: 232, 234, 292, 296.

San Pedro: 56.

San Pedro: $37,175$.

San Sebastián, villa y presidio de: I I, I 2,14 , I 5 , I $8,32,38,42,46,48$, 5.0, $53,54,62,63,74,75,76$, I 05,108 , I I $1,236-240,249,250,251,264$.

"Santa Ana", nao: 24.

Santa Ana: 296.

Santa Bárbara: $38,221$.

Santa Bárbara, río de: 253.

Santa Bárbara, valle de: 21, 243.

Santa Catalina Tepehunes, presidio: 239.

Santa Cruz: $3^{\text {I }} \mathrm{S}$

Santa Cruz, río: 269, 310.

Santa Cruz del Mayo: 304.

Santa Eulalia: 260.

Santa Fe de Nuevo México: 68.

Santa María: 278, 3 I 2.

Santa Rosa de Corodeguachi: 309, 3 I 9.

Santiago Papasquiaro: 42 .

Santisteban: Io6.

Santisteban, conde de, virrey del Perú: 288.

Santo Tomás: 312.

Sant Remo: 26.

Sareba: 70.

Sarmiento Valladares, José, virrey de N. España: 308.

Sartillón, Pedro Francisco: 195-197, 203, $219,222$.

Sauer, Carl: 40.

Sevilla: 6, I4, 93, I 4 .

Sevilla, Juan Leonardo de: i 58.

Sepúlveda, Francisco de, S. J.: I8o, 233.

Sepúlveda, Ignacio de: 284 .

Seris, indios: $61,64-67,72,165,235$, $247,254,26 \mathrm{I}, 262,268,284,309,310$, 3I $2,316,3$ I9.

Serva: $285,3: 3$.

Sicilias, Dos: 93.

Sierra, Juan de: 198-200, 203, 222.

Sierra Osorio, Lope de: I29, I31, 136, I 67 .

Sierra de Pinos: 107.

Sinaloa: I-8, I I-1 3, I 6, 18-22, 24, 26, $29,30,37,39,40,42,46,53,54,58$. $6 \mathrm{I}, 64,65,68,7 \mathrm{I}, 73,76,8 \mathrm{I}, 85-$ I03, I05, I08, III, II2, II4, II5,
I 20-I 22, I 3I-I 59, I 6 I, I64, I65, I 68, I72, I 74, I75, I $81,183.195,201,204$, $206,216,220,228-230,233-236,240-$ $25 \mathrm{I}, 255,256,259-264,286.29 \mathrm{I}, 294$, $301,303,308$.

Sinaloa, presidio de: $22,4 \mathrm{I}, 46,47,54$, $55,65,67,86,93,94$, 102, 116, 132I 36,138 , I 52 , I69, I 75 - 88 I, 230, 239$253,256,257,260-265,274,28 \mathrm{I}, 286$, $287,289,292,296,297,299,302,303$, $305,307-3$ II, 3I3, 3I4, 3I7, 319.

Sinaloa, río: vid. Petatlán.

Sinaloa, villa de San Felipe y Santiago cle: 4 , II, I2, 25, 26, 40, 4I, 46, $48,52-55,58,59,104,105,108$, 110 , II $2,133,138,141,171,172,174-178$, ISo, I85, I 86, I 88,19 I, I92, 207, 212 , II $8,224-228,230,236,246,247,253$, $254,257,264,287,290,302,303,305$, 308.

Sinaloas, indios : 59,244 .

Sinaloa la Vieja: 54, 244.

Sinoquipa: 70 .

Siona, indio: 66.

Soba: 72.

Sobaipuris, ilidios: $72,268,3 \mathrm{IO}, 3 \mathrm{I} 2$, $313,315,318$.

Sobas, indios: 3 10, $3^{1} 2$.

Soberanes, Tomás de: 54 .

Soledad de Janos: 276, 277, 279, 28r.

Solis, Antonio de: 3 I 4-317.

Solis Miranda, Francisco de: I 36,230 , 263.

Soloneto: 106.

Sombrercte: 39 .

Somoza, Antonio de: ror.

Sonora: I-8, 2I, 37-39, 42, 43, 45, 55, $6 \mathrm{I}, 64-72,76-79,8 \mathrm{I}$, I08, II I I 4, I 21-I 23, I 26, I 27, I 32-I 34, I 36, I 52 , I 53, I $61, I 64-I 66, I 68, I 72, I 74$, $175,179,181,183,184,187,188,194-$ $225,228.230,234,23.5,242,248,25.1-$ $260,262-287,292.294,302-304,304-$ 314,319 .

Sonora, compañía de: 312-319.

Sonoras, indios: 64,304 .

Sonora, río y valle de: 70 , I I 2, I 32 , $220,247,252,253,262,269,312$.

Sosas: 224 .

Suaques, indios: $59,243,244,249$. 
Suacui: $;$, 248 .

Sulrez, Antonio: $23 \mathrm{I}$.

Sulitez, Fis. Juan : 252.

Suari: 206 .

Sumas, indios: $43,72,163,-253,254$, $265,266,268-270,273,275,276,278$, $279,482,203,286, \quad 300-3 \tau 2$.

Sura: 205 , 299 .

Suri, Diego, indio: 268, 260.

\section{T}

Tabrla: $28,46,56,57$.

Tacolimlio: $57, \quad 105$.

Tacupeto: $38,43,292-206,298,300$, $302-305,307,308,3 \mathrm{II}$.

Talues, indios: 55 .

Tamázula: I86, I $S_{7}$, I $S_{9}, 226$.

Tamazula, rio de: 63 .

Tamiclopa: $273,2 S_{4}$.

Tiampica: 12.

Tapia, Gonzalo de, S. J.: $5,4 z, 240$, 243 .

Tapia Palacios, Matcos de: 40.

T:pipa: 292, 295, 296, 299, 305, 308.

Tarahtmara: $43,78,133,257,258,260$, $2 \mathrm{~S}_{4}, 29 \mathrm{I}-308,3 \mathrm{I} 8$.

Tamhumanas, indios: 43,71 , I58, $254 *$ $50,290, \quad 92-308,310$.

Titraichi: $292,296,299,305.308$.

Tasina, Manuel, itrdio: 273.

Tebacas, indios: 55 .

Tebacasame, Juan, indio: 274 .

Tetideguachi: $70,266,273,275,278$, 3 IO.

Tebolots: 46.

Teconnacagues, indios: 3 I2.

Tecoripa: $71,19 \mathrm{~S}, 24 \mathrm{~S}$.

Tecorito: 46 .

Tecuichamona : 56 .

Tecuchiapa: 247 .

Teculimeto: 46 , I 06.

Tehueco: $175,176,190$.

Tehueces, indios: 59, 176, 243-245.

Tejeda, Antonio de: 50 .

Tello, Prudencio: 137, 138, 233.

Teopari: 7 I, 292, 293, 305.

Tepache, Santa Ana de: 69, II 2, 266, $270,272,277$.

Tepelunates, iudios: $17,63,237,239$, $246,259$.
Tepic: 107, 291.

Tejoca, keñol de: 204, 299 .

Tepuche: 46,56 .

Jepustla, indios: $61,53,64$.

Terin de los Rios, Domingo: S, 40, $85,104$ I I 3, II $4,116,1] 7$, 120, $139 \mathrm{n}$ $152, \quad 157,287 \cdot 290, \quad 204,200, \quad 3[\%$

Teras: $207,252,284$.

Tercera, ila: 53 .

Terrenate: 260,315 .

Tenticaclit: 69, 70, 112, $806,252,253$, $265,206,270,273,274,277,282,286$, 309-3I今, 3I 4, 3IS, 319.

Tiburón, isla : 319 .

Timamoche: I o7.

Tinola: 4 f.

Tirol: 03 .

Tlaxcala: 68.

Toape: $70,252,253$.

Toledo: 5I, 93.

Toledo, Trancisco de, viruey del Perú: $\mathrm{I}_{4} 2$,

Tolobato: 106.

Tomo: $42,46$.

Tonochi: 43 .

Tonibavi : 3 I 8 .

Tonichi: $7 \mathrm{I}, 257$.

Topia: $15,17,28,30,42,48,73,236$.

Toro: $187,250$.

Torovaca, puerto: 24.

Tosoconoche: 273,275 .

Tovar, Pedro de: Iz.

Treto, Domingo ile, S. J. : 1 So, 226, 227. Tributos: 25, I05, I07, I00, III, I34, 164, I67, I68, I79, Tis.

Trapa, Santiago de: $3 \delta, 221-222,22.4$, 3 I9.

Tubares: I $8 S$.

Tubutama: 315, 316.

Tucapa: 299.

Tucumena: I I I,

Turuque, Ignacio, indio: 269, 272.

Tutuaca: $43,200$.

U

Udicuto: 37 .

Uparo, indios: vid. Seris.

Ualuitoa: 316.

Urbina Samaniego, Diego de: $102,103$. 
Urdinola, Francisco de: I5-1 7, 20, 26, $29,3 \mathrm{I}-34,45,47-49,52,54,58,60$, $74,76,78$, I 2, I 22 , I 29 , I 30, I64, $237,243$.

Ures: 70 .

Uríaz, Pedro de: 223.

Urique, Montsernat de: $260,204$.

Uriquibel, Juan de: 75 .

Uro, Juan, indio: 272.

Uter, Juan de, S. J.: 221 .

\section{V}

Vaca: I 87, 248, 250 .

Vaca, Juan: 282.

Vacapa: 16.

Vadirruato: 56.

Valdés, Gaspar de: 225 .

Valdés, Juan de: 158, 196, 197, 201.

Valdés, Luis dé: So, 129, 132, 1 3.3, I 35, I 62,163 .

Valencia : 93 .

Valencia, Pedro de: 79, 272.

Valencia, José de: 272.

Valenzuela, Nicolás de: I 97.

Valero, Sebastián: 284.

Vandersipe, Diego, S. J. : 59.

Varela, Juan, S. J. : 59.

Vargas Zapata, Diego de: I66, 3 г 3, 3 I4.

Varohíos, indios: 250.

Vázquez de Coronado, Francisco: 19, 40.

Vázquez de Espinosa, Antonio: 118.

Vázquez Mejía, Diego: 49.

Vega, Miguel de la: 187, I88, I9 1.

Vega, Pedro de la: r96, 232.

Veitia, José de: I02.

Velasco, Diego de: $54,236,240$.

Velasco, Luis de, virrey de Nueva España: 17.

Venegas, Miguel, S. J.: 26, 27, 255, 25.6.

Vera, Rodrigo de: 33 .

Veracruz: I 54, I58, 289.

Verber, Diego de: 50.

Verdugo, Lázaro: 136, I66, 265-270, 272.

Vesga, Mateo de: 1 35, 249.

Villanueva, Miguel de: 232.

Villaumbrosa, conde de, marqués conde de Castronuevo: I02.
Villena, marqués de, virrey de Nueva España: I32.

Vinapa: 56.

Virrey: 4, 7, I7, 22, $31,34,35,78,8 x$, $85,88,90,91,96,103,104,109,114$, I I $8,120,128,129$, I 32-I59, I62, I66, I $81,229-23 \mathrm{I}, 237,240,243,249,250$, $256,260-265,288,291,300,302,307$, 3 I $2-314$.

Visitas: I 21-130, I86-187, I89, I9n, I98, 224 .

Vitoria, Alonso de, S. J.: $23 \mathrm{I}$.

Vivero, Rodrigo de: $236,237$.

Vizcaíno: $46,56,105$.

Vizcaya: 93.

Volado, Pascual : 278.

\section{W}

Warren, Fintan: 2 I 2.

Washington: 48 .

West, Robert C. : 29-30, 6I, 164.

\section{Y}

Yaqui, río: $38,43,54,61,70,76,132$, $225,245-249,25 \mathrm{I}, 262,286,287,290$, 294, 298.

Yaquis, indios: 60, 6I, I 73, 225, 245. $247,254,283,284,294,304-306$.

Yebalito: $46,56,106$.

Yécora: 71, 292, 295, 296, 299, 302, $303,305-308$.

Yécoras, indios : 257.

Yegualito: 106.

Yepachi : 296.

Yepómєra: 291, 296.

Yucatán: I 63 .

\section{Z}

Zabala : 194 .

Zabala, Ignacio de, S. J.: 59.

Zacatecas: $37,39,60,69$, I65, 243, 3. 3 .

2.amudio, Pedro de: I 35.

Zapata: 70.

Zapatero, Juan: 50.

Zía: 315.

Zuaques, indios: vid. Suaques.

Zubiate, José de: 305, 307.

Zuro, Juan : 50 . 


\section{PUBLICACIONES}

DE LA

\section{QECULLA DE ESTUDIOS HISPANO - AMERICANOS}

\section{OBRAS PUBLICADAS:}

1 Anuario de Estudios Americanos VoI. I.-Sevilla, 1941.-XII+814 págá, 17 láms. $24 \times 17 \mathrm{cms},-1.500 \mathrm{grs}$-AGOTADO.

2 Pérez.Enlid, Florentino: El Almirantazgo de Castilla hasta las Capitulaciones de Santa Fe.-Sevilla, 1944.-XVI+186 págs., 5 ilust., $14 \times 17 \mathrm{cms}$; rística, con sobre. cubierta. -360 grs.-AGOTADO.

3 Giménez Ferníndez, Manuel: Las Bulas Alcjundrinas de 1493 referentes a las Indius.--Sevilla, 1944.-XVI+258 págs., 5 ilust., $24 \times 17$ cms.; rústica, con sobrecubierta.-450 grs.-AGOTADO.

4 Menoria de Gobierno de José Femaindez de Abascal y Sousa, V'irrey del Perú. Edición de Vicente Rodriøuez Casado y José Antonio Calderón Quijano. Estudio preliminar de Vicente Rodriguez Casado.-Sevilla, 1944. Dos tomoz CLII+495 y 58 : páğ., 15 lím:, $20 \times 13$ cms. Tela, con sobrecubierta.-1.750 grs.-AGOTADO.

5 Ciillerón Quijano, José Antonio: Belice. J663-1821.--Sevilla, 1944.-XIV+504 págs,, 32 líms., $20 \times \mathbf{J 6}$ cms.; tela, con sobrecubierla. -850 ors. $-\Lambda$ GOTADO.

6 Carro, O. P., Venancio D.: La Teología y los teólogos-juristas españoles ante la Conquista de América.-Matrit, 1944,-2 tomos, 453 y 473 paiga., $22 \times 16$ cms.; lela, con sobrecubierta-1.250 Gr:-ACOTADO.

7 Rumen de Arnas, Antonio: Colón en Barcelona.-Sevilla, 1944.-XII + 86 págs. $21 \times 17$ ems. 170 gr:- -AGOTADO.

8 Jos, Faniliano: Investigaciones sobre la vida y obras iniciales de D. Fernands

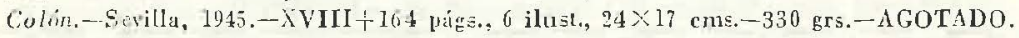

9 Anumio de Latudios Americanos. Vol. II.-Sevilla, 1945,-XVIIL + 936 págs., $24 \times 17$ cms. -1.790 grs.-AGOTADO.

114 Layle, S. J., Constantino: El protector de indios. - Sevilla, 1945. - VIII + 176 párz., $21 \times 17 \mathrm{cms},-325$ grs.-AGOTADO.

11 Gutiérrez de Arce, Manuel: La colonización danesa cn las Islas Virgenes.-Sevilla, 1915.-VIII+161 pigss, 6 láms. $24 \times 17$ cms,; 275 grs.-AGOTADO.

12 Iolimanu Villena, Guillermo: El arte dramático en Lima durante el Virreinato. Marlrid, 1945.-XX+647 págs,, $22 \times 16$ cms.; tela, con sobrecubierta; 1.050 grs. AGOTADO.

13 Alonso Gelino, O. P., P. Luis: Influencia de los dominicos en las Leyes Nuevas. Sevilla, 1945.-VIII + 94 págs., $24 \times 17$ cins.; 170 grz.-AGOTADO.

14 Las Leyes Nuevas, 1512.1543. Reproducción fotodrálica. Transcripción y notas de Antonio Muro Orejón.-Bevilla.-XXI + 26 págs., $24 \times 17$ cms.-AGOTADO.

15 Céspedes del Cástillo, Guillermo: La avería en el comercio de Indias.-Sevilla, 1945. VIII +| 187 páčs.., 8 láms., $24 \times 17 \mathrm{cms.;} 300$ grs.-AGOTADO.

16 Matilla Tascón, Antonio: Los viajes de Julián Cutiérrez al Golfo de Urabá. Scvilla, 1945.-VII + $34 \mathrm{p}$.5., 4 lams., $24 \times 17$ cms; 195 grs.-AGOTADO.

17 Palacio Atard, Vicente: El Tercer Pacto de Familia.--Sevilln, 1245.-XVII +377 páginss; 3 lóms., $22 \times 16 \mathrm{cms.;} \mathrm{tela,} \mathrm{con} \mathrm{sobrecubierta.-600} \mathrm{grš,-AGOTADO.}$ 
18 Múzquiz de Miguel, José Luis: El Conde de Chinchón, Virrey del Perú.-Sevilla, 1945. - 334 págs., 16 láms., $22 \times 16$ cms.; tele, con sobrecubierta; 650 grs. $-\Lambda G 0$. TADO.

19 Pérez Embid, Florentino: Los descubrimientos en el Atlántico hasta el tratado do Turdesillas.-Sevilla, 1948.-370 págs., 35 láms., $22 \times 16$ cma.; tela, con sobro. enbierta; 760 gru.-AGOTADO.

20 Portillo y Dicz de Sollano, Alvaro del: Descubrimientos y expediciones en las costas de California.-Madrid, 1947.-540 págs., 57 láms., $22 \times 16$ cms.; tela, con nobrecubierta; 900 Era.-ACOTADO.

21 Memoria de gobierno de Manuel Amat y Junient, Virrey del Penú, Edición y estudio preliminar de Vicente Rodríguez Casado y Florentino Férez-Embid.-Sevilla, 1947. XCII +845 págs., 12 líms., $20 \times 13$ cms.; tela, con sobrecubierta; 800 gra-AGOTADO.

22 Ayala, F. Javier do: Ideas politicas de Juan de Solórzano. - Sevilla, 1946. XIII + 583 pága, $22 \times 16 \mathrm{cms}$; tela, con sobrecubierta; 1.080 grs.-AGOTADO.

23 Lohmann Villena, Guillermo: El Conde de Lemos, Virrey del Perú,-Madrid, 1946. XVIII +472 págá, 11 láras; $22 \times 16$ cms., tela, con sobrecubierła; 800 grs.-AG0. TADO.

24 Arregui, Domingo Lízaro de: Descripeión de la Nueva Galicia. Edición y estudio de Franģois Chevalier,-LXXI+161 págs, 4 laims., $24 \times 17$ cms.; 490 gra.-AG0TADO.

25 Agir, Fr. Miguel de: Servidumbres personales de indios. Edición y estudio preliminar de F. Javier de Ayala,-Sevilla, 1946.-LII+141 págs., $24 \times 17 \mathrm{cms.;} 450 \mathrm{grs}$. AGOTADO.

26 Memoria de gobierno de Joaquín de la Pezuela, Virrey del Perú. Edición y Prólogo de Vicente Rodriguez Casado y Guillermo Lobmann Villena.-Sevilla, 1947.XLVI+912 páğs., 3 láms., $20 \times 13$ cms.; tela, con sobrecubierta; 850 gra.-AGOTADO.

27 Rodríguez Casado, Vicente; Pérez-Embid, Florentino: Construcciones del Virrey Amat.-Sevilla, 1949.-XII+307 págs., 58 láms., $22 \times 16$ cms.; 500 grs.-AG0TADO.

28 Schafer, Ernesto: El Consejo Real y Supremo de las Indias en la administración colonial.-Sevilla. Centro de Estudios de Historia de América (I tomo) y E. E. H. A. (II tomo), 1935 y 1947. $-X V I I I+434$ y XV 680 págs., 5 láms., $25 \times 17$ cms,; tela, con sobrecubierta; 2.500 grs.-AGOTADO.

29 Rumazu, José: La región amazónica del Ecuador en el siglo XVI.-Sevilla, 194j XII+ 268 págs., 12 láms., $24 \times 17$ cms.; 500 grз.-AGOTADO.

30 Palacio Atard, Vicente: Areche y Guirior: Observaciones sobre el fracaso de una visita al Perú.-Sevilla, 1946.-VIII+106 pảgs., 5 láms., $24 \times 17$ cms.; 200 gramos. AGOTADO.

31 Anuario de Eseudios Americanos. Vol. III.-Sevilla, 1946.-XYI+1.306 págs., 50 lá minas, $24 \times 17$ cms.; 2.300 grs.-AGOTADO.

32 Herráez S. de Escariche, Julia: Don Pedro Zapata de Mendoza, gobernador de Cartagena de Indias:-Seville, 1946.-VIII+137 págs., 6 láms., $24 \times 17$ cm8.; 250 grs. AGOTADO.

33 Giménez Fernández, Manuel: Las doctrinas populistas en la independencia de Hispanoamérica.-Sevilla, 1947.-VIII+156 págs., $24 \times 17 \mathrm{cms.;} 300$ gro.-AGOTADO.

34 Céspedes del Castillo, Guillermo: Lima y Buenos Aires, Repercusiones económicas y políticas de la creación del Virreinato del Plata.-Sevilla, 1947.-VIII+214 págs., 6 láms., $24 \times 17$ cms.; 400 grs.-AGOTADO.

35 Rumeu de Armas, Antonio: Los viajes de John Hawkins a América (1562-1595). Sevilla, 1947.-XX + 486 págs., 26 láms., $22 \times 16 \mathrm{cms.;}$ tela, con sobrecubierta; 650 grs,-AGOTADO.

36 Angulo Iñiguez, Diego: El Gótico y el Renacimiento en las Antillas. Arquitecturn. escultura, pintura, azulejos, or/ebreria.-Sevilla, 1947.-VIII+101 págs., 81 ilust., $24 \times 17$ cms.; 200 grs. - AGOTADO. 
Díz Peneo, Feruando: Las campañas militares del virrey Abascal--Sevilla, 1948 XIII+th6 pigs., $22 \times 16$ cms, ; tela, con sobrecubierta; 500 grs,-AGOTADO.

33 Aurario de Estudios Americanos. Vol. IV.-Sevilla, 1947-XVIII+804 págs., 44 lá. misas e ilust., 24\%17 cms; 1.500 grs-AGOTADO.

39 Estudios Americanos. Vol. I, núus. 1, 2, 3 y 4.-Sevilla, 1949. 812 págs,; $25 \times 17$ cms. ACOTADO.

40 Diaz de Iranli, Gonzalo: La vuelte al mundo de la expedición de la vacuna. Próloz̃ do Gregorio Marañỏn.-Sevilla, 1948.-XVI+102 págs., 20 láms,; $24 \times 17$ cms.; rústica, con solbreculierta; 300 gre.-AGOTADO.

41 (Bil Munilla, Octavin: Malviras. El conflicto anglo.español de 1770,-Sevilla, 1948. VIIJ-1-154 pags.; $24 \times 17 \mathrm{cms.}: 257$ grs.-AGOTADO.

42. Leturia, S. J., Pedro de: La Encíclica de Pio VII (30 de enero de 1816) sobre la Revolución Hispanoamericana. - Sevilla, 1948. - VIII +93 pígs., $24 \times 17$ cmg.; 195 granos-AGOTADO.

43 Giménez Fernández, Manuel: Hernán Cortés y su reuolución comunera en la Nucun España-VII+144 pígs., $24 \times 17$ cm5.; 295 grz.-AGOTADO.

44 Anturion de Esturlios Americanos. Vol. V.-Sevilla, 1948.-XVI+280 págs., 25 lárus. $24 \times 17 \mathrm{cms}$.; $1.450 \mathrm{grs} .-$ AGOTADO.

45 Cascajo Romero, Juan: El Pleito de la curación de la lepra en el Hospital de San Lízara de Lima.-Scyilla, 1948.-VIII+I18 págs., 6 láms.; $24 \times 17$ cms.; 200 gra. AGOTADO.

4h Borregán, Alonso: Crónica de la conquista del Perú. Edición y prólogo de RafaeI Loredo.-Sevilla, 1949.-124 págs.; $24 \times 17$ cms.; 200 grs.-AGOTADO.

47 Molina Argüello, Carlos: El Gobernador de Nicaragua en el siglo XVI.-Sevilla, 1919.-XII+256 páge; $22 \times 16$ cme.; 400 grs.-Col. Dos Colores.-AGOTADO.

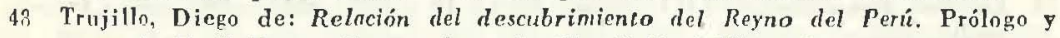
rintaq de Raúl Porras Barrenechea.-Sevilla, 1948.-XIV+124 págs.; $24 \times 17$ cms.; 210 grs.-AGOTADO.

19 Santa Cruz, Alonso de: Crónica de los Reyes Católicos. (Inédita hasta ahora). Publicación de Juan de Mala Carrinzn.--Sevilla, 1951,--2 vols, de CCC +367 págs. el tomo I, y X +646 , el II ; $22 \times 16$ cnss.; 1.250 grs. -600 peselas.

50 Lohmann Villena, Guillermo: Las minas de Huancavelica en los siglos XVI y XV11. - Sevilla, 1949.-XVII + 466 págs., 9 láms.; $22 \times 16 \mathrm{cms.;} 750$ ggrs.; rústica, con Entreculierta.-AGOTADO.

51 Catálogo de documentos de la Sección novena del Archivo General de Indins. Dirigida por Cristóbal Bermúdez Plata: Tomo I.-Sevilla, 1949.-822 págs. 1.450 gramos.-AGOTADO.

52 Herrícz, S. de Escariche, Julia: Beneficencia de España en Indias.-Sevilla, 1947.-II+182 págs., 4 láms.; $22 \times 16$ cms.; 300 grs.-AGOTADO.

53 Jos, Emiliano: Ciencia y osadía sobre Lope de Aguirre el Peregrino.-Sevillo, 1950. -XII+168 págs., 7 láms., $22 \times 16$ ems.; 300 grs.-AGOTADO.

54 Gil Munilla, Octavio: El Rio de la Plata en la Politica Internacional. Génesis lel Virreinato.-Sevilla, 1949.-XIV+464 págs., 8 láms.; $22 \times 16$ cms; 700 grs.; rủs. lica, coll sobrecubierta.-AGOTADO.

55 Mareo Dorta, Enrique: Cartagena de Indias,-Sevilla, 1951.-XXIV+326 págs.; 3 liminas, 170 figuras; $32 \times 22 \mathrm{cms} ; 1.550 \mathrm{grs}$; tela con sobrecubierta.-AGOTADO.

50 Pulido Ruloio, José: El Piloto Mayor de la Casa de la Contratación de Sevilla.-Sevilla, 1950.-VIII+948 págs.; $22 \times 16$ cms,; rústica, con sobrecubierta.-AGOTAD0.

57 Carvajal y Robles, Rodrigo: Fiestas de Lima. Edición y prólogo de Frencieco López Esırada.-Sevilta, 1950.-XXIV+198 págs., 2 lúms.; $22 \times 16$ cms.; 350 grs.; rústica, con sobrecubierta.-AGOTADO. 
58 Pérez.Enbid, Clocentino: Diego de Ordás, compañero de Ciortás y exiplorador del

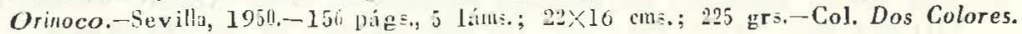
AGOTADO.

59 Estudios Amerionos. (Vol. I1, nums. 5, 6 y 7).-Sevilla, 1950.- 1 GOTADO.

60 Calderón (Mujant, Jose Antonio: Fortificaciones en Nueva España-Sevilla, 1953.-

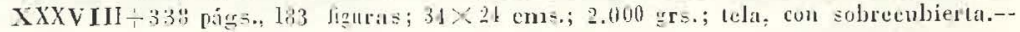
900 peselas.

61 Anuario de Estulios Americunos, Vol. VI.-Sevilla, 1949.-X1V-t-825 pígs.; $21 \times 17$ centimetro: 1.120 gr:- AGOTADO.

62 Estudios Americunos. Pol. 111 (uims. 8, 9, 10 y 11), - Sevi!la, 1951.-25+17 cms. AGOTADO

63 Gusinde, Martí:: Fueguinos. Tradueción de lin ohra limenschen im Feuerland, por

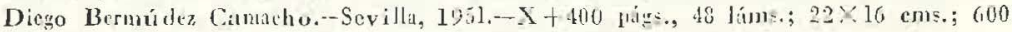
gramos. -3 rio peselas.

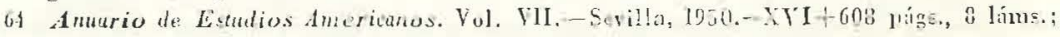
$24 \times 17$ cms.; 900 grs.-900 peselas.

65 Muro Orejon, Antonio: Cristobal Colin. El orizinal de la capitulación de $1492 \quad y$ sus copins concmporaneas.--Sevilla, 1951.-12 págè, 8 fotogrubados: $24 \times 17$ cms.; 65 grs. - AGOTADO.

66 Mirco Dnsta, Enrigac: Fumens paru la Historia del Arte Hispano-Americano. - Se. villa, 1951.-XXIII + 730 págs.; 24f-17 cms.; 700 grsı-AGOTADO.

67 Morales Padrón, Francisco: Jamaica Española,--Sevilla, 1952.-XXXII +504 pátrs, 22 láms., 1 mapa; $22 \times 17$ cms.; 650 gršs tela, con sobrecubierta.-600 pesetas.

68 Porras Truconis, Cabriel: Nistoria de la Cultura en el Nuevo Reino de Granada.-Sevilla, 1952.-Xł-652 págs., $22 \times 16$ ems.; 700 grs.-AGOTADO.

69 Estudios Americanos. Vol. IV (nims. 12, 13, 14 y 15).-Sevilla, $1952 .-25 \times 17$ cms. AGOTADO.

70 Mariluz Urquijo, José María: Ensayo sobre los juicios de residencia indianos.--Se. villn, 1952.-XX+520 págs.; $22 \times 16$ cms.; 400 grs.-Cıl. Dos Colores.-120 pesetas.

71 Giménez Fernández, Manuel: Barlolomé de las Casas. Tomo I: El Plan Cisneros. Las Casas vara la reformación de las Indias.-Sevilla, 1955.-XXIV -776 págs., 30 láms., 22※.j ems.; 1.350 grs.; tela, con sobrecubierta [vitl. núm. 121].-AGOTADO.

79 Anuario de Estudios Anericunos. Vol. VIII.-Scvilla, 1951.-XII+658 págs.; $24 \times 17$ centimetrus; 980 grs. -900 pesetas.

73 Estudios Americanos, Vol. V (núms. 16, 17, 18, 19 y 20).-Sevilla, 1953.

71 Estudios Americanos, Vol. VI (nums. 21, 22, 23, 24, 25, 26 y 27).-Sevilla, 1953.

75 Armas Median, Fernando de: Cristianizacion del Perí.-Sevilla, 1953.-XXVIII+610 páginas, 14 folograbados y mapas; 1.000 grs.; tela, con sobrecubierta. 600 pesetas.

76 León Pinelo, Antonio: El Gran Canciller de las Indias. Edición, estudio y notas do Guillermo Lohniann Yillena.-Sevilla, 1954.-CLXXIV+232 págs., 22×16 cms.; rústica, con sobrecubierta; 500 grs. -360 pesetas.

77 Anuario de Estudios Americanos. Vol. IX.--Sevilla, 1952.-XVI + 780 págs., 5 láminaz y gráficos.-24X17 cms.; 1.050.-AGOTADO.

78 Peñalver Simó, Patricio. Mudernidad tradicional en el pensamiento de Jovellanos.Sevilla, 1953.-XXXII+168 págs.; $20 \times 13$ cms.; 210 grs.-Col. Mar Adentro.-AGO. TADO.

79 Elías de Tejada, Francisco: Las doctrinas politicas de Raimundo de Farias Brito. Sevilla, 1953.-196 págs.; $20 \times 13$ cms.; 200 grs.-Col. Mar Adentro.-120 pesetas.

80 López Niñez, Carlos: Horizonte doctrinal de la Sociologia llispano-Americana.-Se. villa, 1953.-164 págs.; $20 \times 13$ cms.; 165 grs.; Col. Mar Adentro.-120 pesetas.

81 Estudios Americanos, Vol. VII (núms. 28, 29, 30, 31 у 32).-Sevilla, 1954. 
52 Tobar, Balthasar de: Compendio Bulnio Indico.(Tomo I) Edición y estudio de

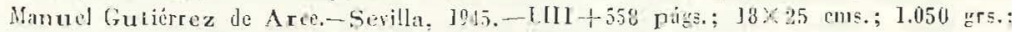
tela, con sobrecubierta. -600 peselas.

93 Inrrea, Juan Ienacio: La Sunfa Scde y el Ecuador--Sevilla, 1954-LIII+176 págz.; $18 \times 25$ cung.; 225 gre.-Col. Dos Colores,-120 pesetaz.

r) Gil Munilla, Ladislao: Descubrimiento del Marañón.-Sevilla, 1954.-XVI+392 páginas, 13 láms; $16 \times 22 \mathrm{cms.;} 600 \mathrm{grav;}$ rústica, con solırecubierta. -300 pesetns.

85 Asis Garrote, Agustin: Bartoloné Herrera.-Sevilla, 195.-148 págs.; $20 \times 13$ cms.; 200 grt.-Col Mar Adentro.-120 pesetas.

86. Viln Solma, José: Procedimiento y técnicas en Rómulo Gallegos,-Sevilla, 1954. 196 pígs.; $20 \times 13$ cus.; 200 grs,-Col, Mar Adentro.-120 peñetas.

87 Tejado Fernández, Manuel: Aspecto de la vida sacial en Cartagena de Indias du. rante el seiscientos.-Sevilla, 1954.-348 págz.; 22X16 cms.; 500 gra.-300 pesetas.

na Anuario de Estudios Americanos. Vol. X.-Sevilla, 1953.-739 págṑ, 9 láms.; 1.050 gramns. -900 pesetas.

if Estudios Americanos. Vol VIII. (Nums. 33.31, 35.36, 37, 38 y 39).-Sevilla, 195.6.

90 liodriguez Casado, Vicente: De la Monarquis Espoñola dol Barroco.-Sevilla, 1955.160 paign,; 20×13 cms.; 180 gr:-Col. Mar Adentro,-AGOTADO.

91 Horales Padrón, Franciseo: El comercio canario-americano en los siglos XVI, XVII y XVIII.-Scvilla, 1955.-XX + 432 páḡ., 26 láms,; $22 \times 16$ cns.; 645 gra.; rústica, con sobrecubierta. -360 pesetas.

92 Levillier, Robrerto: Los Incas.--Sevilla, 1956.-260 pägs. y un mapa plegable; $22 \times 16$ cms.; 360 grs.-Col, Dos Colores. -200 pesetas.

93 Morales Parlón, Francisco: Fisonomía de la Conquisea Indiana,-Sevilla, 1955.XII + 182 págs.; $20 \times 13 \mathrm{cms} ; 200$ grs.-Col. Mar Adentro.-AGOTADO.

91 Asís Garrole, Agustín: Iders sociopoliticas en Alonso de Polo (El Tostado).-Sevilla, 1955.-160 págs.; $20 \times 13$ cms.; 180 grs,-Col. Mar Adentro.-120 pesetas.

95 Rodil, Jusé Ramón: Memoria del sitio del Callao. Edición, estudio preliminar y notas fle Vicente Rodriguez Casado y Guillermo Lobnunn Villena-Sevilla, 1955. $\mathrm{XXX}+344$ págz,; $20 \times 13 \mathrm{cms}$; 500 grs.-360 pesetas.

96 Elías de Tejada, Erancisco: El pensamiento politiro de los fundadores de Nucun Granada.-Sevilla, 1955.-XII+262 págs.; $20 \times 13$ cms.; 275 grs.; Col. Mar Adentro. 120 peselas.

97 Estudios Americanos. Vol. IX. (Núm:. 40.41, 42, 43-14 y 45).-Sevilln, 1955.

on Estudios Americanos. Vol. X. (Núms. 46, 47, 48, 49 y 50-51).-Sevilla, 1955.

99 Aluro Orejón, Antonio: Cedulario Americano del siglo XVIII.-Sevilla, 1956.XCVI+834 págs.; $24 \times 17$ cms.; 1.300 grs.; rústica, con eobrecubierta.-720 pesetas.

100 Morales Padeón. Francisco: Rebelión contra la Compañia de Caracas.-Sevilla, 1955.-146 págs.; 12 láms.; $25 \times 18 \mathrm{cms}$; rústica, con sobrecubierta; 250 grs.-120 ptas.

101 Estudios Americanos. Vol. XI. (Nủms. 52, 53, 54, 55, 56).-Sevilla, 1956.

102 Antario de Estudios Americanos. Vol, XI, Sevilli, 1954,-21×17 cns._820 págs., 50 láms. -900 pesetss.

103 Estudios Americanos. Vol. XII. (Núms. 57-58, 59, 60, 61, 62, 63).-Sevilla, 1956,

104 Annario de Estudios Americanos. Vol. XII.-Sevilla, 1955.-989 págs., 28 láms.; $24 \times 17$ cms. -900 pesetas.

105 Estudios Americanos. Vol. XIII. (Nỉms. 64.65, 66, 67.68, 69.70).-Sevilla, 1957.-

106 Arcila Farias, Eduardo: El Régimen de la Encomienda en Venezuela.-Sevilla, 1957.-378 págs.; $22 \times 16$ cms.; 500 gre.-Col. Dos Colores.--AGOTADO.

107 Acevedo, Edherto Oscar: El ciclo histórico de la Revolución de Mayo.-Sevilla, 1957.-378 págฐ.; $20 \times 13$ cms.; 300 grs.-Col. Mar Adentrn.-120 pesetas.

108 Alvar, Manuel: La poesía de Delmira Agustini.-Sevilla, 1958.-VII+113 págs.; 4 ilust.; $20 \% 13$ cms.-Col. Mar Adentro.

109 Estudios Anericanos. Vol. XIV. (Núms. 71.72, 73.74, 75).-Sevilla, 1957. 
110 Estudios Americanos. Vol. XV. (Núms. 76-27, 78.79, 80.31).-Sevilla, 1958.

111 Muro Orejón, Antonio: Ordenanzus Reales para el buen regimiento y tratamiento de los Yndios. (Las Leyes de I512-1513). -Edición y estudio.-Sevilla, 1959. 85 págs.; 32 lims.; $24 \times 17$ ems.; rústica.-AGOTADO.

112 Rubio Merino, Pedro: Don Diego Camacho y Avila, Arzobispo de Manila y de Guadalajara de México. (1695.1712).-Sevilla, 1958.-XVIII+651 págz.; 7 ilust.; $16+22 \mathrm{cms},-300$ pesetns.

113 Anuario de Estudios Americanos. Vol XIII.-Sevilla, 1956. -604 pizss; $24 \times 17$ cms., AGOTADO.

114 Estudios Americanos. Vol XVI. (Núms. 82-83, 84-85, 86-87).-Sevilln, 1958.

115 Anuario de Estudios Americanos. Vol. XIV.-Sevilla, 1957, -636 págs. $-24 \times 17 \mathrm{cms.}$ Hustraciones, 1.000 grs.-AGOTAD0.

116 Coulthard, G. R.: Raza y Color en la Literatura Antillana.-Sevilla, 1959. VIII +175 páginas; 20×13 cms.; $190 \mathrm{grb}-$ Col. Mar Adentro.-120 pesetas.

117 Diaz.Trechuelo, María Lourdes: Arquitectura Bspañola en Filipinas,-Seville, 1959. 193 líms.; $24 \times 17$ cms.; 1.500 grs. -900 pesetss.

118 Nnvarro Garcia, Luis: Intendencias en Indias.-Sevilla, 1959.-226 págs.-19 mapas, $22 \times 16$ cms.; 350 grs.-Col. Dos Colores. -240 pesetas.

119 Collantes de Terán, Juan: Las novelas de Ricardo Güiraldes.-Sevilla, 1959,-XV+209 páginas; $20 \times 13 \mathrm{cms},-$ Col. Mar Adentro,-AGOTADO.

120 Anuario de Estudios Americanos. Vol. XV. Sevilla, 1958. -769 pígs., $24 \times 17$ cms. Ilustraciones, -900 pesetas.

121 Giménez Fernández, Mnnuel: Bartolomé de las Casas. Tomo II: Politica Inicial de Carlos $I$ en Indias.-Sevilln, 1960,-1.352 págs.; 23 lims.; 31 fotoc.; $25 \times 18$ cms.; 1.700 grs. [vid. num. 71]. -900 pesetas.

122 Romero Gómez, Manuel: La Constitución Británica.-Sevilla, 1960.-144 páginas; $20 \times 13$ cms.; 55 grs.-Col. Mar Adentro. -120 pesetns.

123 Estudios Americanos. Vol. XVII, (Nüms. 90.91, 92.93, 94.95, 96.97, 98.99).-Sevilla, 1959.

124 Muro Orejón, Antonio: Ordenanzas Reales del Consejo de las Indias.-Sevilla, 1957, 3 págs. +56 fotograbados; $24 \times 17 \mathrm{cms}, ; 100 \mathrm{grs} .-120$ pesetas.

125 Estudios Americanos. Vol. XIX (núms. 100, 101, 102). indice.-Sevilla, 1960.

126 Anuario de Estudios Americanos. Vol XV1.-Sevilla, 1959.-743 páģı; $24 \times 17 \mathrm{cma}$. Ilustraciones. -900 pesetas.

127 Ruiz, Helena: La búsqueda de Eldorado por Guayana.-Sevilla, 1959.-XIV+166 páginns +18 lims.; $24 \times 17 \mathrm{cms}$; $350 \mathrm{grs} .-120$ pesetns.

128 Real, José Joaquín: Las Ferias de Jalapa.-Sevilla, 1959.-XII +148 pága.+9 láminas. $24 \times 17$ cms.; 300 grs. -120 pesetas,

129 Lohmann Villena, Guillermo: Las relaciones de los virreyes del Perú.-Sevilla, 1959, 218 págs.; $24 \times 17$ cms.; 300 grs,-180 pesetas.

130 Muro Orejón, Antonio: Las Leyes Nuevas.-Sevilla, 1961.-59 págs. Reproducciones facsimilares, transcripción y estudio. $-24 \times 17 \mathrm{cms}$; $150 \mathrm{grs},-120$ pesetas.

131 Estudios Americanos. Vol. XX. (Núms. 103, 104, 105).-Sevilla, 1960.

132 Pedro Borges: Los conquistadores espirituales de América.-Sevilla, 1961.-189 págo.; $20 \times 13 \mathrm{cms}$; $200 \mathrm{grs},-$ Col. Mar Adentro. -120 pesetas.

133 Estudios Americanos. Vol. XXI. (Núms. 106, 107, 108).-Sevilla, 1961.

134 Anuario de Estudios Americanos. Vol. XVII.-Sevilla, 1960.-810 págs.; $24 \times 17 \mathrm{cms}$. Ilustraciones. -900 pesetas.

135 Anuario de Estudios Americanos. Vol. XVIII.-Sevilla, 1961.-819 págs., $24 \times 17$ cms. Ilustraciones. -900 pesetas.

136 Rodriguez del Valle, Mariana: El Castillo de San Felipe del Goljo Dulce.-Sevilla, 1968.-103 págs. +28 líms. $-24 \times 17$ cms.; 250 grs. -120 pesetas. 
137 Campo Lacasa, Cristina: La Iglesiu en Puerto Rico en el siglo XVIII.-Sevilla, $1962 .-127$ pág..+20 líns.; $24 \times 17$ cms.; 250 grs. - 120 pesclas.

130 Lutue Alcuide, Eliza: La Sociedad Económica de Guatemala.-Sevilla, 1962.220 págs.; $22 \times 16 \mathrm{cms} ; 350 \mathrm{grs} .-$ Col. Dos Colores. -180 pesetas.

139 Estudios Americunos. Vol. XXII (en prenza).-Sevilla, 1962.

140 Cordoncillo Sumada, José María: Historia de la Reul Lotería en Nueva Eispaña (1770.1821).-Sevilla, 1962.-139 nágs.+14 lóns.; $24 \times 17$ cms.; 350 grs.-120 pesetaz.

141 Muro Orejón, Antonio: (Antonio de León Pinelo). "Libros Reales de Gobierno y Gracia". Contribución al conocimiento de los Ceduluios del Archivo de Indias (1.492.1650). Estudio y edición.-Sevilla, 1962,-04 páę.-Reproducción facsimilar. $2.4 \times 17 \mathrm{cms} ; 150$ grs. -120 pesetas.

142 Calderón Quijano, José Anlomio y Luis Navarco Carcía: Bibliotect Nacional de Paris. Museo Britanico. Public Record Office. Guia de Locumentos, mapas y planos españoles y americanos.-Sevilla, 1962.-70 págs.; $24 \times 17$ cvıs.; 100 grs.-120 pesctas.

143 Anuario de Estudios Americanos. Vol. XIX.-Seviliu, 1962.-378 págs. $24 \times 17$ cms. Ilustraciones. 1.400 gre.-900 pesetas.

14 Calderón Quijano, J. A.: El Banco de San Carlos y las Comuridades de indios de Nueva España.-Sevilla, 1963.-24X17 cms.; 144 págz; 250 grs.-120 pesetas.

145 Markman, Sidney David: San Cristóbal de Las Casas.-Sevilla, 1963, 24×17, 115 páginas. Ilustraciones. 250 grs. -180 pesetas.

145 Pikaza, Otlo: Don Gabriel José de Zuloaga Gobernador le Venezuela. Sevilla, 1963, 24×17; 195 págs.; 250 grs.-120 pesetas.

147 Muro Orejón, Anlonio, Pérea Lmbid, Florentimo, y Morales Padrón, Franciscu: Pleitos Colombinos.-Sevilla, 1964. XXXI-555 págs. $25950 \times 18$ crns., 1.600 grs., 950 pesetas.

148 Navarro García, Luis: Don José de Gálvez y la Comandancia General de las Pro. vincias Internas del Norte de Nueva España.-Sevilla, 1964.-24X17 cms.; IX-+602 páginas; 133 ilustr.; 1.100 grs. -720 pesetas.

149 Córdova Bello, Eleazar: Compañias holandesas de Navegación. - Sevilla, 1965. $24 \times 16$ cras.; VII +303 páge.; 2 ilustr.; 500 grz.--300 pesetrs.

150 Muro Orcjón, Antonio: Los capítulos de corregilores de 1500.-Sevilla, 1963, 28 pág8. 16 fotograbados; $24 \times 17 \mathrm{cms}$; $120 \mathrm{grs.}-120$ pesetas.

15] Anuario de Estudios Americanos.-Vol. XX.-Sevilla, 1963.-24×17 cms.; 862 págs.; 1.300 grs. -900 pesetas.

152 Rodriguez Macís, Juana: El Correo en Puerto Rico.-Sevilla, 1964, 94 púgs, $24 \times 17$ cms.; 175 gr8. -100 pesetas.

153 Mariscal Romero, Pilar: Los Bancos de Rescate de Platas.-Sevilla, 1904.-255 págs., 1 láms.; $24+17$ cms.; 175 grs. - 100 pesetas.

154 Lohmann Villena, Guillermo: Las defensas militares de Lima y Callao hasta 1746. Sevilla, 1964, 217 págs.; 32 láms.; $24 \times 17$ cmz.; 400 grs. -240 pesetas.

155 Pajarón Parody, Concepción: El Gobierno en Filipinas de don Fernando Manuel do Bustamante y Bustillo (1717.1719).-Sevilla, 1964, 131 págs., 4 líms., $24 \times 17$ cms., 225 grs. -100 pesetes.

156 Morales Padrón, Francisco, y Llavador Mira, José: Mapas, Planos y Dibujos sobre Venezuela existentes en el Archivo General de Indias (Primera serie).-Sevilla, 1964.-86 págs.; 38 láms.; $24 \times 17$ cms.; 250 gr6. -120 pesetas.

157 Indice del Anuario Estudios Americaros.-Sevilla, 1961.-24X17 cms.; 136 págs.; 200 grs. -100 pesetas.

158 Díaz-Trechuelo Spinola, Lourdes: La Real Compañía de Filipinas.-Sevilla, 1965. $24 \times 17$ cms.; XIX +366 págs.; 13 ilustr..-360 pesetas.

159 Deustua Pimentel, Carlos: Las Intendencias en el Perí (1790-1796).-Sevilla, 1965. $22 \times 16$ cms.; XXVIII+263 págs.; 300 grs.-Col. Dos Colores. 240 pesetas.

160 Anuario de Estudios Americanos.-Vol. XXI. Sevilla, 1964.-24X17 cme.; 907 págs.; 1.400 grs. -900 pesetas. 
161 Garrido Conde, María Teresa: La creación del virreinato de Nueva Granada (1717.1723). Sevilla, 1965.-24X17 cms.; 120 págs.; 1 lóms.; 200 grs.-100 pesetas.

162 Nuvarro Garcia, Luis: Las provincias internas en el siglo XIX. Sevilla, 1965.$24 \times 17$ cms.; 133 págs.; 12 lámss; 240 grs. -120 pesetas.

163 Morales Padrón, Francisco, y Llavador Mira, José: Mapas, Planos y Dibujos sobre Ven ezuela existentes en el Archivo General de Indias. (Segunda serie).-Sevilla, 1965. $24 \times 17$ cms.; 75 págs.; 36 lámı; 250 grs. -120 pesetas.

164 Anuario de Estudios Americanos. Vol. XXII, Sevilla, 1965. $24 \times 17$ ems. 900 pesetas.

165 Gómóz Aparicio, Josefina: Pérdida de la isla de Trinidad. Sevilla, 1966. 24×17 cms. 230 páginas. 2 láminas. 120 pesetas.

166 Cuello Martinell, Marí Angeles: La renta de los naipes en Nueva España. Sevilla, $1966,24 \times 17 \mathrm{cms} .105$ págs. 100 pexetas.

167 Tobar, Bulthasar: Compendio del Bulario Indico (Tomo II). Estudio y edición de Manuel Gutiérres de Arce. Sevilla, 1966. $17 \times 24 \mathrm{cms} .435$ págв. 350 pesetas.

168 Navarro García, Lais: La Sublevación Yaqui de 1740. Sevilla, 1966. $24 \times 17$ cm9. 159 págs.' 1 lámina, 120 pesetas.

169 Vila Vilar, Enriqueta: Los rusos en América. Sevilla, 1966. $24 \times 17$ cms. 9 láminas. 104 págs. 120 pesetas.

170 Lohmann Villena, Guillermo: Juan de Matienzo. Autor del "Gobierno del Perú". (Su perzonalidad y fu obra). Sevilla, 1966. $24 \times 17 \mathrm{~cm} 5.120$ páge. 120 pezetas.

171 Rodriguez Bacna, Maria Luisa: La Sociedad Económica de Amigos del País de Manila en el siglo XVIII, Sevilla, 1966. $22 \times 16$ ems.; XIV +216 págs.; $300 \mathrm{gr}$. Colección Dos Colores. 250 pesetas.

172 Gonzilez Martín, Jorónimo Pablo: Cinco poetas franco-canadienses actuales, Sevi11a, 1966. $20 \times 13$ cms.; 167 púgs.; 250 grs. Col. Mar Adentro. 120 pesetas.

173 Sarrablo Aguareles, Engenio: El Conde de Fuenclara. Bmbajador y Virrey de Nueva España (1687-1752). Tomo I, Sevilla, 1955. $17 \times 24$ cms.; X+330; 525 gr6.; 300 pesetas,-Tomo II, Sevilla, 1966. $17 \times 24$ cms.; 709 páge.; 1.000 grs.; 500 peseta6.

174 Anuario de Estudios Americanos. Vol. XXIII, tomo I, Sevilla, 1966. 792 págs. $24 \times 17 \mathrm{~cm}$. Ilustraciones, 900 pesetas.

175 Estudios Lascasimos. IV Centenario de la muerte de Fray Bartolomé de las Casas, 1560-1966. Sevilla, 1966. 474 págs. $24 \times 17$ cms. Hustraciones, 500 pesetas.

176 Navarro Garcia, Luis: Sonora y Sinaloa en el siglo XVH. Sevilla 1967. $22 \times 16 \mathrm{cms}$. 319 págs. Ilustraciones. 350 grs, 300 pesetas,

\section{Próximas publicaciones:}

177 Calderón Quijano, Joxé Antonio: El Gobierno de los Virreyes de Nueva España durante el reinado de Carlos $I I I$. Dirección y estudio preliminar por Tomo I: El Virrey Marqués de Gruillas, par María del Pópulo Antolín Eapino; Et Marqués de Groix, por Luis Navarro Garcin; Don Antonio M. ${ }^{a}$ de Bucareli, por M.. Lourdes Diaz.Trechuelo, Concepción Pajarón, M. ${ }^{B}$ Luifa Rodríguez Baena.

178 Calderón Quijano, José Antonio: El Gobierno de los Virreyes de Nueva España durante el reinado de Carlos III. Dirección de Tomo II: Don Martín de Mayorga, por Joáé Joaquin Real y Antonia M. Heredia; Don Matías de Gálvez, por Mariana Rodriguez del Valle y Angeles Conejo; Don Bernardo de Gálvez, por Carmen Galbis Diez; Don Alonso Núñez de Haro, por Adolfo Rubio Gil.

179. Sánchez Bella, Immael: La organización financiera de las Indias (siglo XVI).

180 Muro Orojón, Antonio; Florentino Pérez Embid, Francisco Morales Padrón: Pleitos Colombinos, Tomo II.

181 Muro Orejón, Antonio: Cedulario Anericano del siglo XVIII. Tomo II. 
